Nevada

Environmental

Restoration

Project

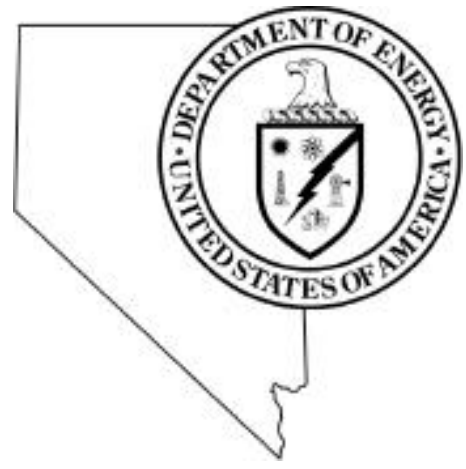

Site Characterization W ork Plan for Gasbuggy, New M exico

Controlled Copy N 0 ::

Revision N 0.: 0

February 2001

Approved for public release; further dissemination unlimited.

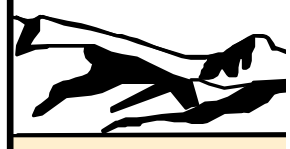

Environm ental Restoration

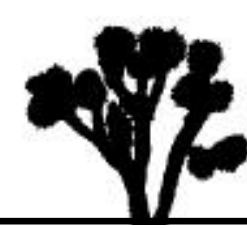

Division 
Available for public sale, in paper, from:

U.S. Department of Commerce

National Technology Information Service

5285 Port Royal Road

Springfield, VA 22161

Phone: 800.553 .6847

Fax: 703.605.6900

Email: orders@ntis.fedworld.gov

Online ordering: http//www.ntis.gov/ordering.htm

Available electronically at http://www.doe.gov/bridge.

Available for a processing fee to U.S. Department of Energy and its contractors, in paper, from:

U.S. Department of Energy

Office of Scientific and Technical Information

P.O. Box 62

Oak Ridge, TN 37831-0062

Phone: 865.576 .8401

Fax: 865.576.5728

Email: reports@adonis.osti.gov

Reference herein to any specific commercial product, process, or service by trade name, trademark, manufacturer, or otherwise, does not necessarily constitute or imply its endorsement, recommendation, or favoring by the United States Government or any agency thereof or its contractors or subcontractors. 


\title{
SITE CHARACTERIZATION WORK PLAN FOR GASBUGGY, NEW MEXICO
}

\author{
DOE Nevada Operations Office \\ Las Vegas, Nevada
}

Controlled Copy No.:

Revision No.: 0

February 2001

Approved for public release; further dissemination unlimited. 


\section{SITE CHARACTERIZATION WORK PLAN FOR GASBUGGY, NEW MEXICO}

Approved by: $\begin{gathered}\text { Signature Approved } \\ \begin{array}{l}\text { Monica Sanchez, Project Manager } \\ \text { Offsites Project }\end{array}\end{gathered}$ Date: $12 / 14 / 2000$

Approved by: Signature Approved

Date: $12 / 14 / 2000$

Runore C. Wycoff, Division Director

Environmental Restoration Division 


\section{Table of Contents}

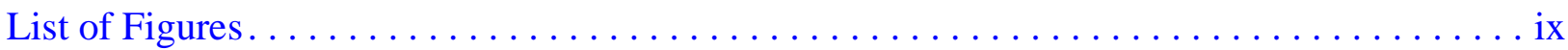

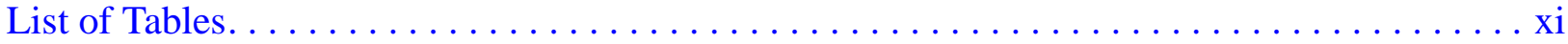

List of Acronyms and Abbreviations $\ldots \ldots \ldots \ldots \ldots \ldots \ldots \ldots \ldots \ldots \ldots \ldots \ldots \ldots \ldots \ldots$

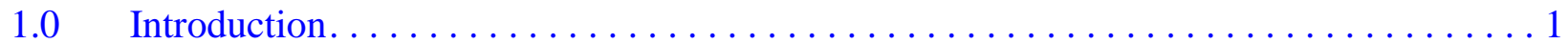

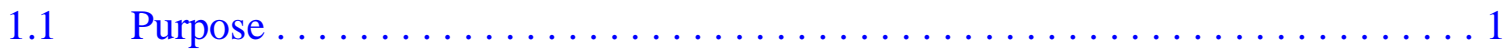

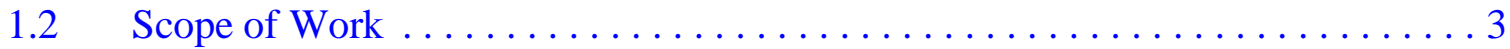

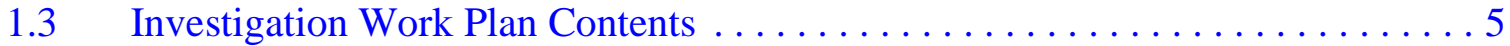

$2.0 \quad$ Facility Description. . . . . . . . . . . . . . . . . . 6

$2.1 \quad$ Physical Setting. . . . . . . . . . . . . . . . . 6

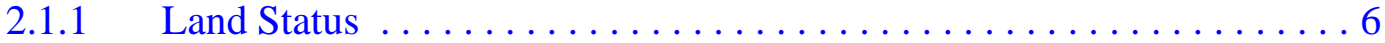

2.1.2 Environmental Setting . . . . . . . . . . . . . . . . . 8

2.1.3 Surface Water, Wetlands, and Floodplains ............... 9

2.1.4 Geology and Hydrology. . . . . . . . . . . . . . . . . . . . . 9

2.2 Operational History. . . . . . . . . . . . . . . . . . . . . 10

2.2.1 Surface Ground Zero Area. . . . . . . . . . . . . . . . . . . 11

2.2.2 Well GB-D Area ........................... 24

2.2.3 Recording Trailer Park. . . . . . . . . . . . . . . . . . . 24

2.2.4 Control Point ... . . . . . . . . . . . . . . . . . . . . . . 24

2.2.5 Helicopter Pad ... . . . . . . . . . . . . . . . . . . . 25

2.3 Previous Investigations . . . . . . . . . . . . . . . . . 25

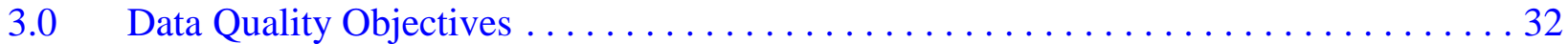

$3.1 \quad$ Conceptual Site Model . . . . . . . . . . . . . . . . . . . . . . 32

3.1.1 Surface Conceptual Site Model . . . . . . . . . . . . . . . . . . . 34

3.1.2 Subsurface Conceptual Site Model . . . . . . . . . . . . . . . . 35

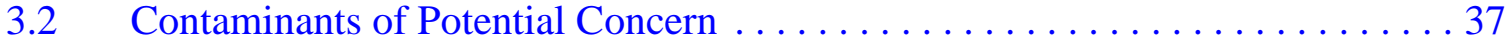

3.2.1 COPCs for Surface and Shallow Subsurface Investigation . . . . . . . . 37

3.2.2 COPCs for Subsurface Investigation . . . . . . . . . . . . . 41

$4.0 \quad$ Surface and Shallow Subsurface Work Plan $\ldots \ldots \ldots \ldots \ldots \ldots \ldots \ldots \ldots \ldots$

$4.1 \quad$ Demarcate Areas of Concern . . . . . . . . . . . . . . . . . . . . 43

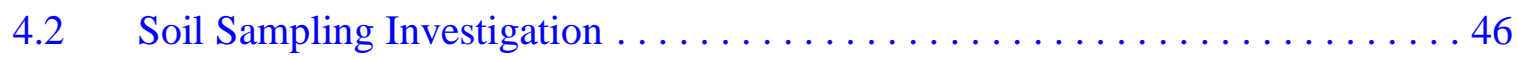

4.2.1 Representative Inorganic Background Sample Collection . . . . . . . . 46

4.2.2 Soil Sampling Techniques . . . . . . . . . . . . . . . . . . 49

4.2.2.1 Soil Boring Techniques ................49

4.2.2.2 Soil Excavation Techniques . . . . . . . . . . . . 49

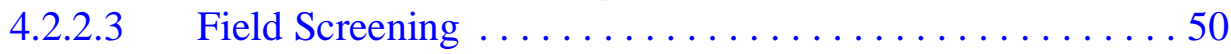

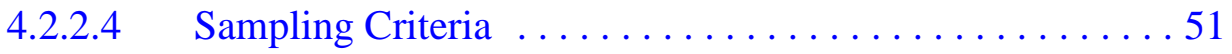




\section{Table of Contents (Continued)}

4.2.3 Soil Sampling Locations for Surface/Shallow Subsurface

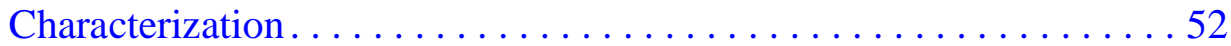

4.2.3.1 Surface Ground Zero Area $\ldots \ldots \ldots \ldots \ldots \ldots \ldots$

4.2.3.2 Well GB-D Area . . . . . . . . . . . . . . . . . 59

4.2.3.3 Recording Trailer Park .................61 61

4.2.3.4 Control Point ...................6 61

4.2.3.5 Quality Control Samples .................6 62

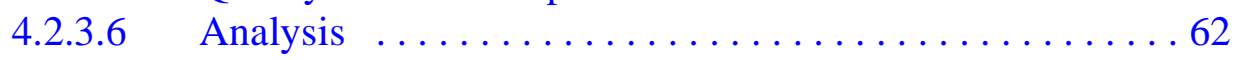

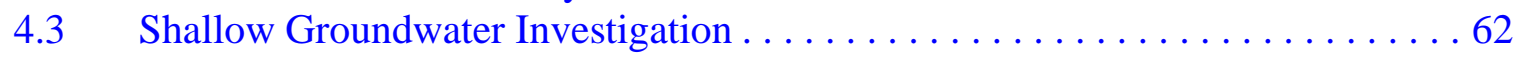

4.3.1 Well Installation and Groundwater Monitoring. . . . . . . . . . . 63

4.4 Additional Requirements and Activities. . . . . . . . . . . . . 63

$4.4 .1 \quad$ Health and Safety. . . . . . . . . . . . . . . . . 63

4.4.2 Environmental Compliance and Waste Management . . . . . . . . . . 64

4.4.3 National Environmental Policy Act Requirements . . . . . . . . . . . 65

4.4 .4 Quality Assurance ........................... 65

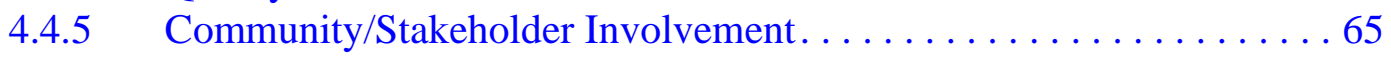

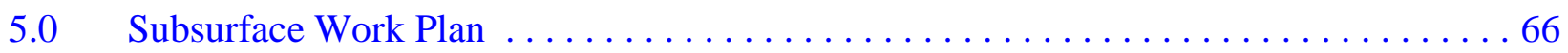

5.1 Conceptual Model of Subsurface Flow and Transport . . . . . . . . . . 68

5.1 .1 Geologic and Hydrogeologic Setting. . . . . . . . . . . . . 68

5.1 .2 Description of the Gasbuggy Test and Its Effects . . . . . . . . 72

5.1.3 Conceptual Model for Contaminant Transport Through

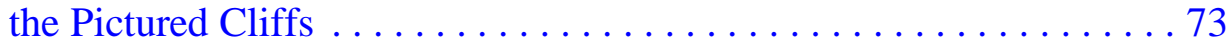

5.1.4 Conceptual Model for Contaminant Transport Through the Ojo Alamo . . . . . . . . . . . . . . . . . . . . . 74

5.2 Data Quality Objectives of Subsurface Investigations . . . . . . . . . . . 77

5.2 .1 Subsurface Modeling DQOs . . . . . . . . . . . . . . . . . . . 77

5.2.2 Well EPNG 10-36 Data Collection DQOs . . . . . . . . . . . . . 78

5.3 Evaluation of Existing Subsurface Data . . . . . . . . . . . . . . 80

5.4 Identification of Proper Numerical Model . . . . . . . . . . . . . 81

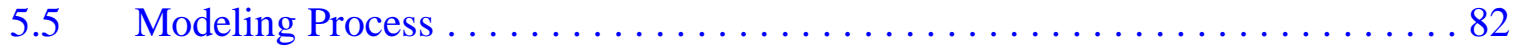

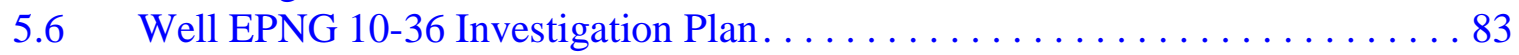

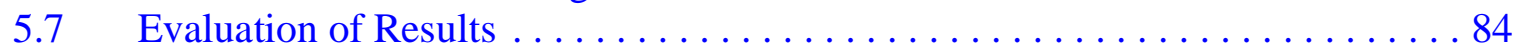

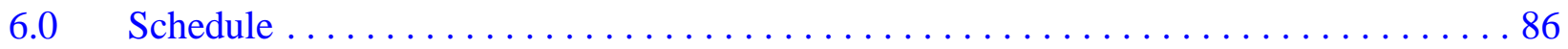

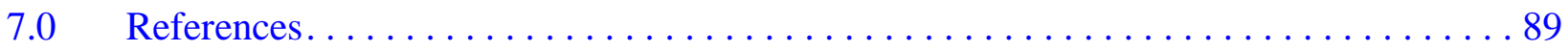

\section{Appendix A - Gasbuggy Historical Radiological Monitoring and Sampling Results}

A.1.0 Summary of Radiological Monitoring and Sampling for the Gasbuggy Site Surface 


\section{Table of Contents (Continued)}

A.2.0 Monitoring and Sampling During Detonation and Posttest Drilling . . . . . . . . A-3

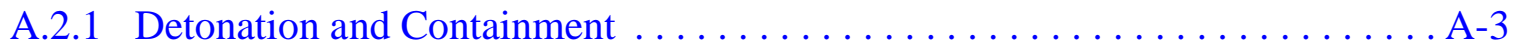

A.2.2 Thermoluminescent Dosimeters . . . . . . . . . . . . . . . . A -3

A.2.3 Remote Area Monitoring System . . . . . . . . . . . . . . . . . . A-4

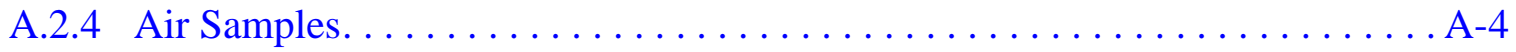

A.2.5 Gas Sampling ..............................

A.2.6 Aerial Surveys. . . . . . . . . . . . . . . . .

A.3.0 Effluent Monitoring During Gas Production Testing . . . . . . . . . . . . . A-6

A.4.0 Restoration Activities . . . . . . . . . . . . . . . . . . . . . . .

A.4.1 Disposal of Radioactive Material . . . . . . . . . . . . . . A-8

A.4.2 On-Site Disposal of Materials. . . . . . . . . . . . . . . . A-10

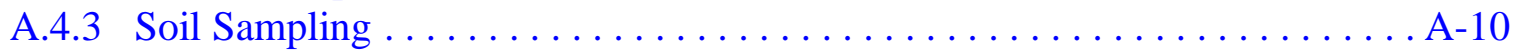

A.4.4 Vegetation Sampling. . . . . . . . . . . . . . . . . . .

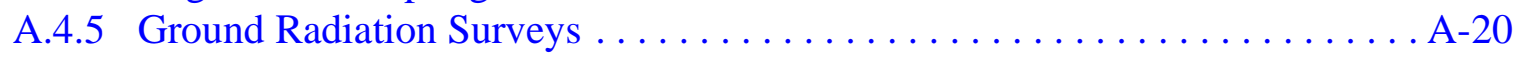

A.5.0 Post-Restoration Sampling and Monitoring . . . . . . . . . . . . . . A-21

A.5.1 Ground Radiation Survey $(1993) \ldots \ldots \ldots \ldots \ldots \ldots \ldots \ldots \ldots \ldots \ldots \ldots \ldots \ldots \ldots$

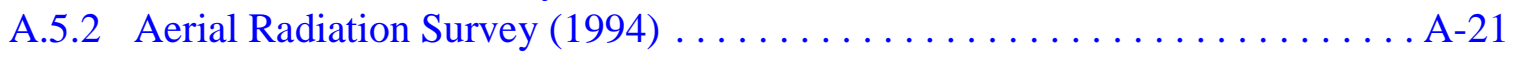

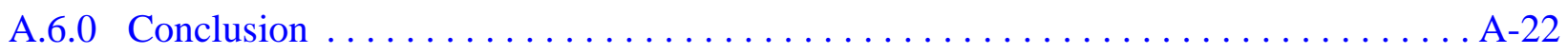

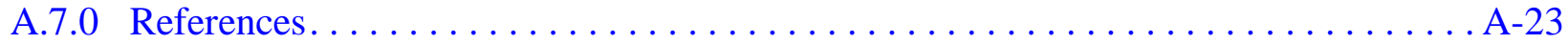

\section{Appendix B - New Mexico Quality Assurance Project Plan}

B.1.0 Introduction. . . . . . . . . . .

B.2.0 Criteria $1-$ Quality Program . . . . . . . . . . . . . . . . . . .

B.2.1 Quality Management Policy .......................... .

B.2.2 Project Organization . . . . . . . . . . . . . . . . . . . . . .

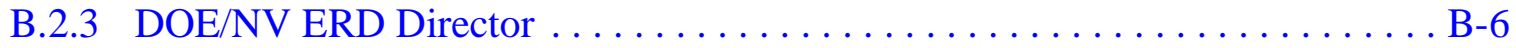

B.2.3.1 NV ERP Project Manager . . . . . . . . . . . . . . . B-6

B.2.3.1.1 NV ERP Task Manager ............... B-7

B.2.3.1.2 NV ERP Quality Assurance Coordinator . . . . . . . . . B-7

B.2.3.2 New Mexico Sites Project Participants . . . . . . . . . . . . . . B-7

B.2.3.3 Analytical Laboratories . . . . . . . . . . . . . . . . . . B-8

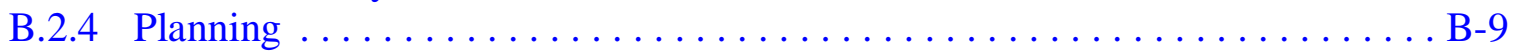

B.2.4.1 Task Initiation $\ldots \ldots \ldots \ldots \ldots \ldots \ldots \ldots \ldots \ldots \ldots . . . \ldots \ldots$

B.2.4.2 Data Quality Objectives........................ B-9 


\section{Table of Contents (Continued)}

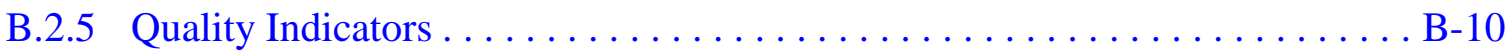

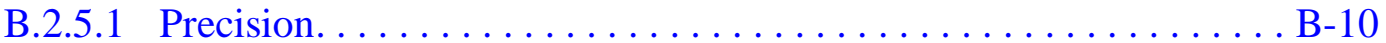

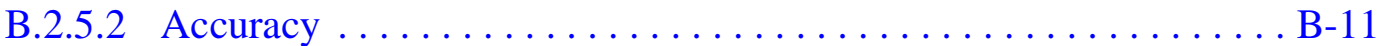

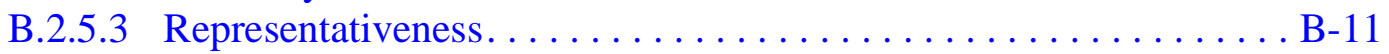

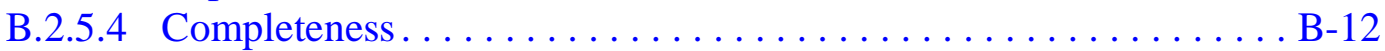

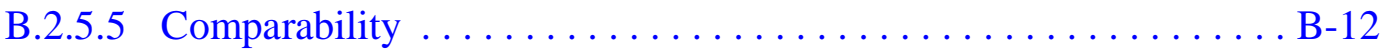

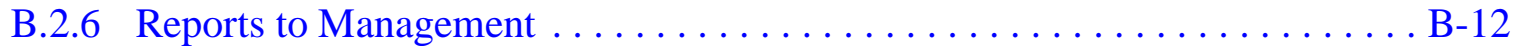

B.2.7 Readiness Reviews . . . . . . . . . . . . . . . . . . B-13

B.3.0 Criteria 2 - Personnel Training and Qualifications ..................... B-14

B.3.1 Project Personnel . . . . . . . . . . . . . . . . . . . . . .

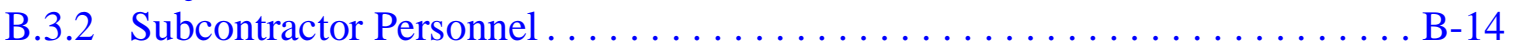

B.4.0 Criteria 3 - Quality Improvement $\ldots \ldots \ldots \ldots \ldots \ldots \ldots \ldots \ldots \ldots \ldots \ldots \ldots$

B.4.1 Internal Quality Control Checks . . . . . . . . . . . . . . . B-15

B.4.1.1 Field Quality Control. ................................

B.4.1.1.1 Equipment Rinsate Blank Samples ............ B-16

B.4.1.1.2 Field Blank Samples ................. B-17

B.4.1.1.3 Trip Blank Samples . . . . . . . . . . . . B-17

B.4.1.1.4 Duplicate Samples ................... B-18

B.4.1.1.5 Source Blanks ...................... B-18

B.4.1.2 Analytical Laboratory Quality Control . . . . . . . . . . . . . B-18

B.4.1.2.1 Laboratory Control Samples . . . . . . . . . . . . . . B-19

B.4.1.2.2 Method Blank Samples . . . . . . . . . . . . . . . B-19

B.4.1.2.3 Surrogate-Spike Samples . . . . . . . . . . . . . B-19

B.4.1.2.4 Matrix-Spike/Matrix-Spike Duplicate Samples ... . . . B-20

B.4.1.2.5 Laboratory Duplicate Samples . . . . . . . . . . . . . B-20

B.4.1.3 On-Site Radiological Laboratory Quality Control. . . . . . . . . . . . . B-21

B.4.1.3.1 Instrument Control Samples . . . . . . . . . . . B-21

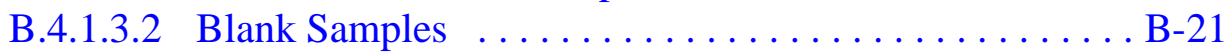

B.4.1.3.3 Duplicate Samples ... . . . . . . . . . . . . . . . B-21

B.4.2 Data Precision, Accuracy, and Completeness . . . . . . . . . . . . . B-21

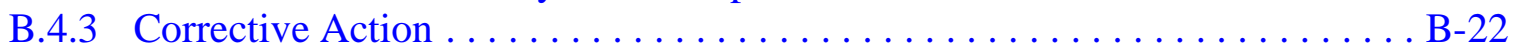

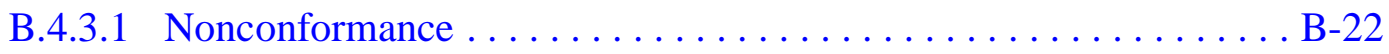

B.4.3.2 Cause Analysis. . . . . . . . . . . . . . . . . . . B-23

B.4.3.3 Trend Analysis. . . . . . . . . . . . . . . . . . . . . . .

B.4.3.4 Lessons Learned $\ldots \ldots \ldots \ldots \ldots \ldots \ldots \ldots \ldots . \ldots \ldots$. . . . . . . . . . .

B.5.0 Criteria 4 - Documents and Records....................... B-24

B.5.1 Documents and Records . . . . . . . . . . . . . . . . . . . B-24

B.5.1.1 Document Review and Control . . . . . . . . . . . . . . . B-24 


\section{Table of Contents (Continued)}

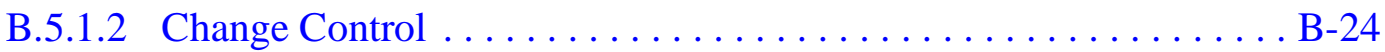

B.5.1.3 Records Maintenance........................... B-25

B.6.0 Criteria 5 - Work Processes . . . . . . . . . . . . . . . . . . . . B-26

B.6.1 Evaluation and Use of Existing and New Data. . . . . . . . . . . . B-26

B.6.2 Computer Hardware and Software . . . . . . . . . . . . . . . B-26

B.6.2.1 Computer Systems . . . . . . . . . . . . . . . . . . . B-27

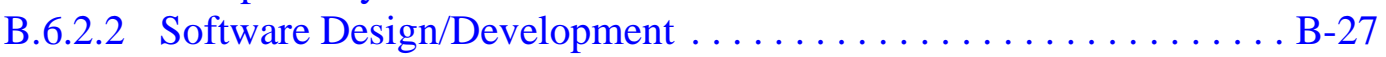

B.6.2.2.1 Code Evaluation ..................... B-28

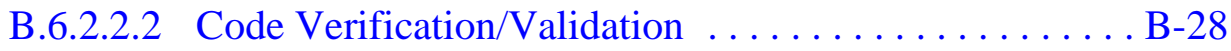

B.6.2.2.3 Software Documentation . . . . . . . . . . . . B-29

B.6.2.3 Peer Review of Software and Code Applications . . . . . . . . . . . . B-29

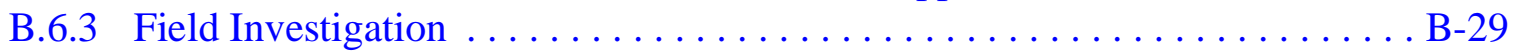

B.6.3.1 Sample Custody . . . . . . . . . . . . . . . . . . . B-30

B.6.3.1.1 Chain of Custody Form . . . . . . . . . . . . B-30

B.6.3.1.2 Custody Seals ...................... B-30

B.6.3.1.3 Sample Labels and Identification .............. B-31

B.6.3.1.4 Sample Handling, Preservation, Packaging,

and Shipping ....................

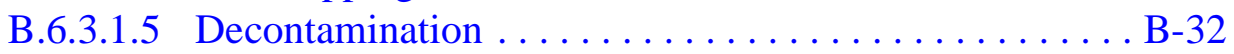

B.6.3.1.6 Investigation-Derived Waste $\ldots \ldots \ldots \ldots \ldots \ldots \ldots$ B-32

B.6.3.1.7 Field Documentation .................. B-32

B.6.3.1.8 Photographic Documentation ................ B-32

B.6.3.2 Identification and Control of Items . . . . . . . . . . . . B-33

B.6.3.3 Calibration and Preventive Maintenance................ B-33

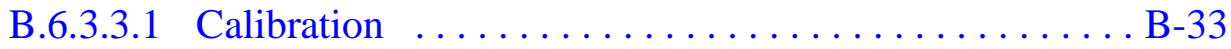

B.6.3.3.2 Preventive Maintenance ................. B-34

B.6.3.4 Laboratory Operation. . . . . . . . . . . . . . . . . B-34

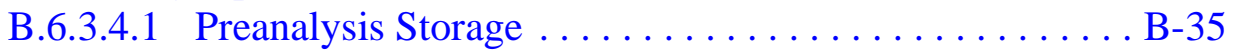

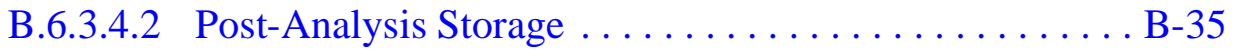

B.6.4 Analytical Data Usability . . . . . . . . . . . . . . . . . . B-35

B.6.4.1 Data Management . . . . . . . . . . . . . . . . B-36

B.6.4.2 Evaluation and Use of Data . . . . . . . . . . . . . B-36

B.6.4.3 Data Reduction, Verification, and Validation . . . . . . . . . . B-37

B.6.4.3.1 Data Completeness Review ................ B-37

B.6.4.3.2 Data Review and Summary . . . . . . . . . . B-37

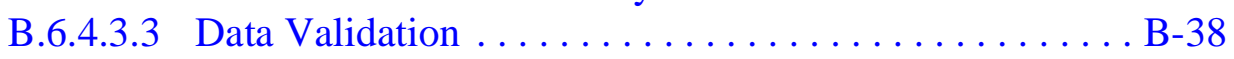

B.6.4.4 Laboratory Data Reporting . . . . . . . . . . . . . . . B-39

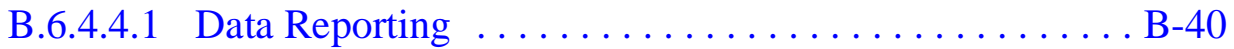

B.7.0 Criteria 6 - Design. . . . . . . . . . . . . . . . . . . . . . . . 


\section{Table of Contents (Continued)}

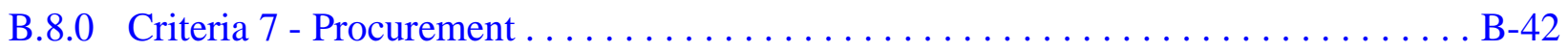

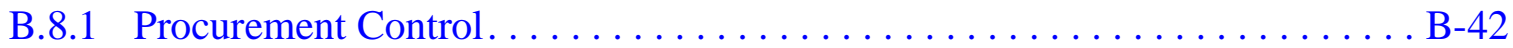

B.8.1.1 Procurement Documents . . . . . . . . . . . . . . . . B-42

B.8.1.2 Measurement and Testing Equipment ................ B-43

B.8.1.3 Verification of Quality Conformance ................ B-43

B.9.0 Criteria 8 - Inspection and Acceptance Testing ................... B-44

B.10.0 Criteria 9 - Management Assessment ............................ B-45

B.11.0 Criteria 10 - Independent Assessments. . . . . . . . . . . . . . . . . B-46

B.12.0 References. . . . . . . . . . . . . . . . . . . . . . . . . . . . . . . . . . . . . B-47

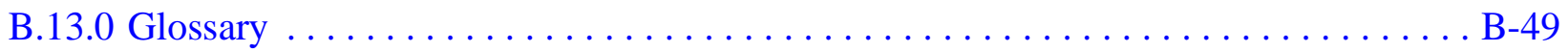

Attachment 1 - Quality Criteria for Site-Specific Documents . . . . . . . . . . . . B-58

Attachment 2 - Laboratory Chemical, Toxicity Characteristic Leaching Procedure, and Radiochemistry Analytical Requirements for New Mexico Sites.......... B-61

Appendix C - Results of Gasbuggy Preliminary Field Investigation (August - September, 2000)

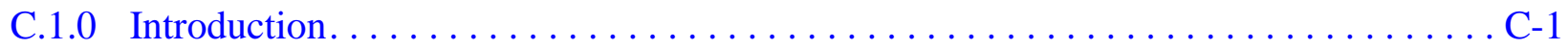

C.1.1 Preliminary Field Investigation Objectives $\ldots \ldots \ldots \ldots \ldots \ldots \ldots \ldots \ldots$ C-1

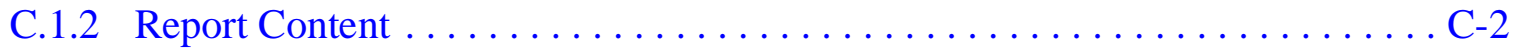

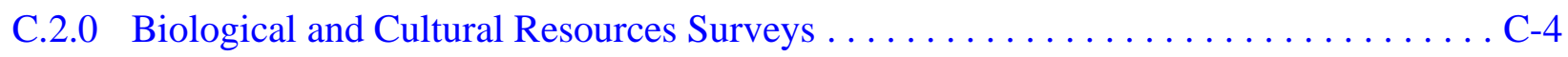

C.2.1 Biological Survey . . . . . . . . . . . . . . . . . . . . . . . . 4

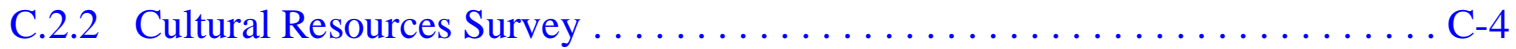

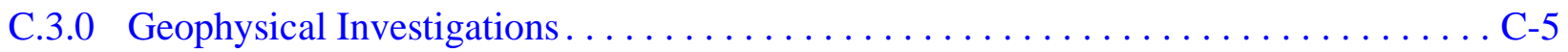

C.3.1 Scope and Objectives of Geophysical Investigation. . . . . . . . . . C-5

C.3.2 Demarcation of Geophysical Survey Areas . . . . . . . . . . . . . C-6

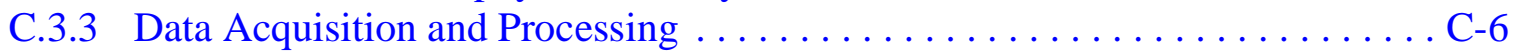

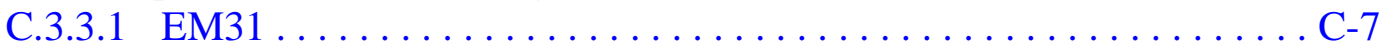

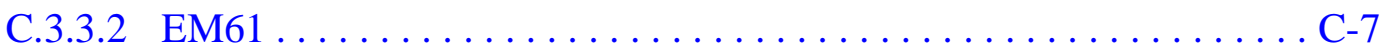

C.3.3.3 Ground-Penetrating Radar . . . . . . . . . . . . . . . C-7

C.3.4 Results of Geophysical Investigation $\ldots \ldots \ldots \ldots \ldots \ldots \ldots \ldots \ldots \ldots \ldots \ldots$

C.3.4.1 Surface Ground Zero Area . . . . . . . . . . . . . . . . 8

C.3.4.2 Well GB-D Area $\ldots \ldots \ldots \ldots \ldots \ldots \ldots \ldots \ldots \ldots \ldots \ldots \ldots$ 


\section{Table of Contents (Continued)}

C.3.4.3 Recording Trailer Park. . . . . . . . . . . . . . . . . C-8

C.3.4.4 Control Point . . . . . . . . . . . . . . . . . . . . . C-13

C.4.0 Sampling Activities. . . . . . . . . . . . 17

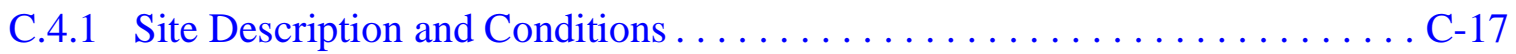

C.4.2 Direct-Push Operation . . . . . . . . . . . . . . . . . . . .

C.4.3 Sample Collection. . . . . . . . . . . . . . . . . . . . . C-17

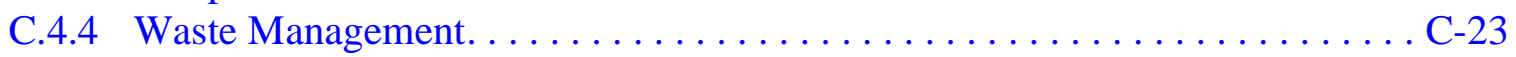

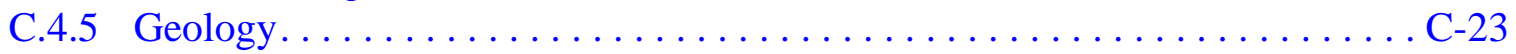

C.4.6 Hydrology . . . . . . . . . . . . . . . . . . 24

C.5.0 Gasbuggy Preliminary Investigation Soil Sample Results . . . . . . . . . . . . C-25

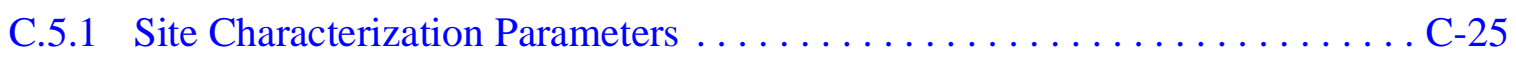

C.5.1.1 Total Petroleum Hydrocarbon Analytical Results . . . . . . . . . . . . C-25

C.5.1.2 Total Volatile Organic Compound Results . . . . . . . . . . . . . . . C-29

C.5.1.3 Total Semivolatile Organic Compound Results . . . . . . . . . . . . C-29

C.5.1.4 Total RCRA Metals . . . . . . . . . . . . . . . . . . . C-34

C.5.1.5 Tritium Results . . . . . . . . . . . . . . . . . C-38

C.5.2 New Mexico Oil Conservation Division-Required Parameters . . . . . . . . . C-40

C.5.2.1 Target Analyte List Metals, Boron, Molybdenum, and Uranium Results . . . . . . . . . . . . . . . C-40

C.5.2.2 Bromide, Chloride, Fluoride, Nitrates, Sulfate, and Cyanide Results . . . . . . . . . . . . . . . . . . . . . . C-47

C.5.2.3 Radium Results ... . . . . . . . . . . . . . . . . . . . . C-47

C.5.3 Waste Characterization Parameters . . . . . . . . . . . . . . C-47

C.5.3.1 Toxicity Characteristic Leaching Procedure Metal Results . . . . . . C-47

C.5.3.2 Toxicity Characteristic Leaching Procedure Volatile Organic

Compound and Semivolatile Organic Compound Results . . . . . . C-47

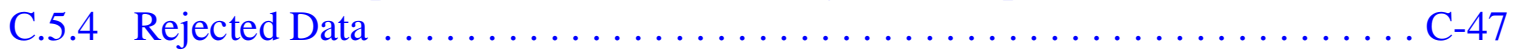

C.6.0 Discussion of Investigation Results for the Surface Ground Zero Area. . . . . . . . . C-54

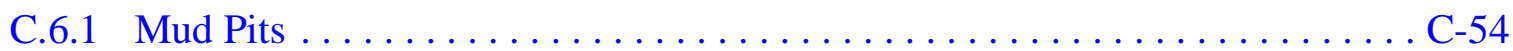

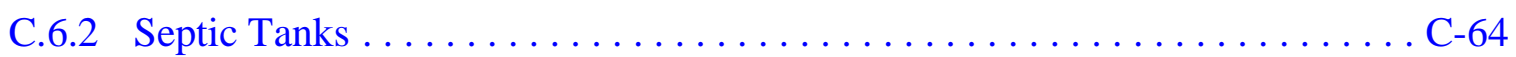

C.6.3 Other Anomalies. . . . . . . . . . . . . . . . . . . . . .

C.7.0 Quality Assurance. . . . . . . . . . . . . . . . . . . . . . 66

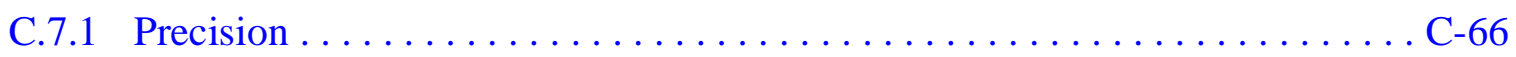

C.7.2 Accuracy................................. C-66

C.7.3 Representativeness . . . . . . . . . . . . . . . . . . . . . C-67

C.7.4 Completeness . . . . . . . . . . . . . . . . . . . . . . . . C-67

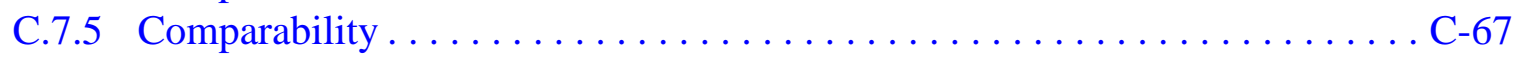




\section{Table of Contents (Continued)}

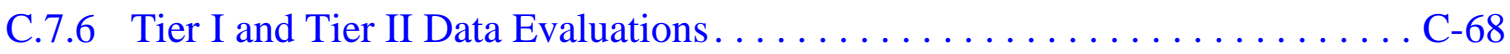

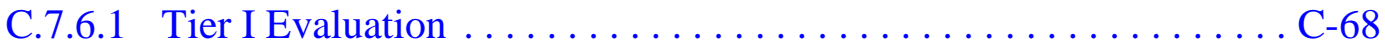

C.7.6.2 Tier II Evaluation. . . . . . . . . . . . . . . . . . . . . . . C-69

C.7.6.3 Tier III Evaluation . . . . . . . . . . . . . . . . . . . C-70

C.7.7 Field Quality Control Samples . . . . . . . . . . . . . . . . . . C-71

C.7.7.1 Field Blank Analysis . . . . . . . . . . . . . . . . . C-71

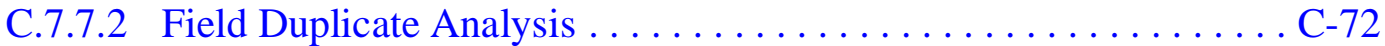

C.7.7.3 Matrix Spike Analysis . . . . . . . . . . . . . . . . . C-72

C.7.8 Laboratory Quality Control Samples . . . . . . . . . . . . . . . C-73

C.7.8.1 Laboratory Surrogate Spikes . . . . . . . . . . . . . . . . C-74

C.7.8.2 Laboratory Duplicate Analysis . . . . . . . . . . . . . . C-74

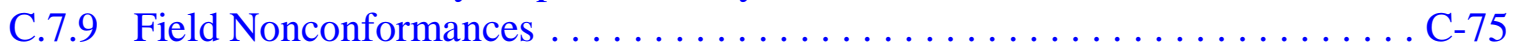

C.7.10 Laboratory Nonconformances $\ldots \ldots \ldots \ldots \ldots \ldots \ldots \ldots \ldots \ldots \ldots \ldots$

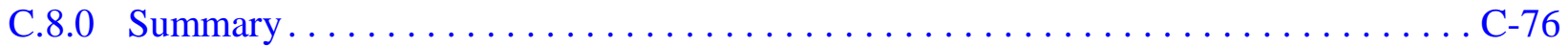

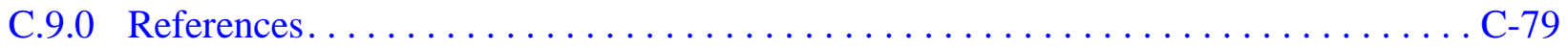

\section{Appendix D - Gasbuggy Site Surface Radiological Dose/Risk Assessment}

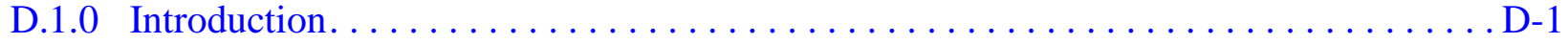

D.2.0 Identification of Radionuclides of Potential Concern. . . . . . . . . . . . . D-2

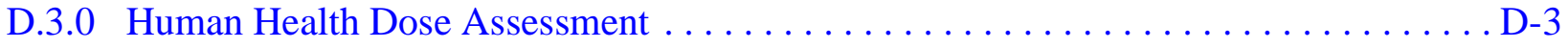

D.3.1 Exposure Assessment . . . . . . . . . . . . . . . . . . . . D-3

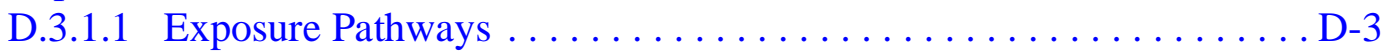

D.3.1.2 Quantification of Exposure ...................

D.3.1.3 Exposure Models . . . . . . . . . . . . . . . . . . . D-7

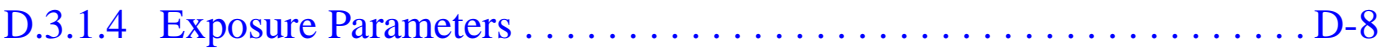

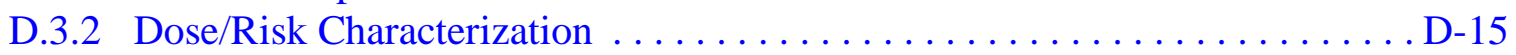

D.3.2.1 Dose/Risk Criteria . . . . . . . . . . . . . . . . . D-15

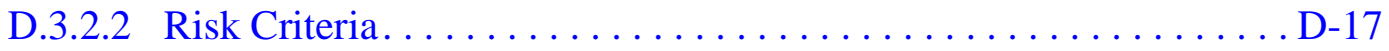

D.3.2.3 Results of the Human Health Dose/Risk Characterization . . . . . . . . D-18

D.4.0 References...................................... D-20 


\section{List of Figures}

Number

1-1 Gasbuggy Site Location Map $\ldots \ldots \ldots \ldots \ldots \ldots \ldots \ldots \ldots \ldots \ldots \ldots \ldots \ldots \ldots \ldots \ldots$

2-1 Gasbuggy Site and Surrounding Area $\ldots \ldots \ldots \ldots \ldots \ldots \ldots \ldots \ldots \ldots \ldots \ldots \ldots \ldots$

2-2 Oblique Photograph of Surface Ground Zero Area

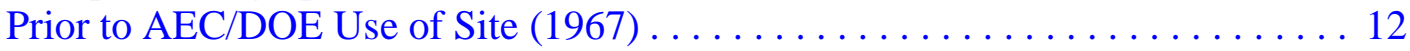

2-3 Surface Ground Zero Site Plan Gasbuggy, New Mexico............. 13

2-4 Oblique Photograph of Surface Ground Zero Area During Drilling of Well GB-E . . . . . . . . . . . . . . . . . . . . . . . . . . . 15

2-5 Oblique Photograph of Surface Ground Zero Area with Well GB-D in Background................................... 16

2-6 Oblique Photograph of Surface Ground Zero Area December 10, 1967 . . . . . 17

2-7 Oblique Photograph of Surface Ground Zero Area Prior to Restoration . . . . . . 18

2-8 Surface Ground Zero Area Status as of December $1976 \ldots \ldots \ldots \ldots \ldots$

2-9 Surface Ground Zero Area Location of On-Site Burials . . . . . . . . . . . 23

2-10 Recording Trailer Park Site Plan Gasbuggy, New Mexico .............. 26

2-11 Oblique Photograph of the Recording Trailer Park ................. 27

2-12 Oblique Photograph of the Control Point ................... 28

2-13 Control Point Site Plan Gasbuggy, New Mexico .................. . . . 29

3-1 Gasbuggy Conceptual Site Model ....................... 33

4-1 Surface and Shallow Subsurface DQO Decision Flow Chart ............. 44

4-2 Example of Sampling Locations........................ 57

5-1 Subsurface DQO Decision Flow Chart. . . . . . . . . . . . . . . . . . 67

5-2 Generalized Hydrogeologic Cross Section of the San Juan Basin . . . . . . . . . . 69

5-3 Generalized Cross Section of Project Gasbuggy Emplacement Hole . . . . . . . . 70

5-4 Location of Wells in the Immediate Vicinity of the Gasbuggy Test . . . . . . 71

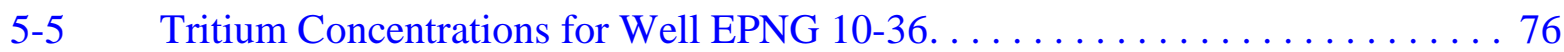

5-6 Status of Well EPNG 10-36 Prior to 1994 Field Activity ................ 79 


\section{List of Figures (Continued)}

Number

6-1 Proposed Schedule for Surface Investigation at Gasbuggy Site . . . . . . . . 87

6-2 Proposed Schedule for Subsurface Modeling of Gasbuggy Site . . . . . . . . . . 88

A.4-1 Location of Surface Sampling Points. . . . . . . . . . . . . . A-12

A.4-2 Location of Profile Sample Sets. . . . . . . . . . . . . . . . . A-13

A.4-3 Location of Post-Operational Soil Samples . . . . . . . . . . . . . A-18

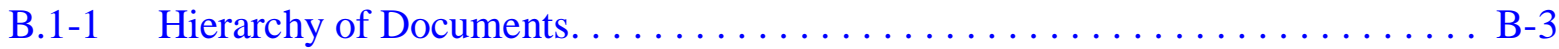

B.2-1 DOE/NV ERD Organizational Chart .................... B-5

C.3-1 Location of Anomalies Identified by EM31 Survey Quadrature Phase Response at the Well GB-D Area. . . . . . . . . . . . . . . . C-9

C.3-2 Location of Anomalies Identified by EM31 Quadrature Phase Response at the Recording Trailer Park . . . . . . . . . . . . . . . . . C-10

C.3-3 Location of Anomalies Identified by EM31 Inphase Response at the Recording Trailer Park . . . . . . . . . . . . . . . . . . C-11

C.3-4 Location of Anomalies Identified by EM31 Quadrature Phase Response at the Control Point . . . . . . . . . . . . . . . . C

C.3-5 Location of Anomalies Identified by EM31 Inphase Response at the Control Point. . . . . . . . . . . . . . . . . . . . . . . . C-15

C.6-1 Location of Anomalies Identified by EM31 Survey Quadrature Phase Response at Surface Ground Zero . . . . . . . . . . . . . . . . . . . . C-55

C.6-2 Location of Anomalies Identified by EM31 Survey Inphase Response at Surface Ground Zero . . . . . . . . . . . . . . . . . 56

C.6-3 Direct-Push Borehole Locations at Surface Ground Zero . . . . . . . . . . . . C-57 


\section{List of Tables}

Number

2-1 Monitoring and Previous Investigations.

3-1 Summary of Gasbuggy Quality Objectives for Surface and Shallow

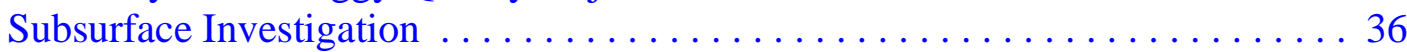

3-2 Summary of Gasbuggy Quality Objectives for Subsurface Investigation . . . . . 38

4-1 Statistical Analysis of RCRA Metal Results for Preliminary Background Soil Samples.

4-2 Calculation of Percent Error and 90 Percent Confidence Interval of RCRA Metal Results for Preliminary Background Soil Samples

4-3 Investigation Strategy for Surface Ground Zero Area Known and Suspect AOCs................................. 53

4-4 Well GB-D Area Known and Suspect AOCs to be Further Investigated. . . . . . 60

4-5 Recording Trailer Park Known and Suspect AOCs to be Further Investigated . . 61

4-6 Control Point Known and Suspect AOCs to be Further Investigated . . . . . . . 62

A.3-1 Radioactive Release Measurements of Gaseous Effluents During Gasbuggy Production Testing $\ldots \ldots \ldots \ldots \ldots \ldots \ldots \ldots \ldots \ldots \ldots \ldots \ldots \ldots \ldots$

A.4-1 Reported Results of Additional Analysis for Samples Collected During 1978 Restoration . . . . . . . . . . . . . . . . . . . . . . . A-9

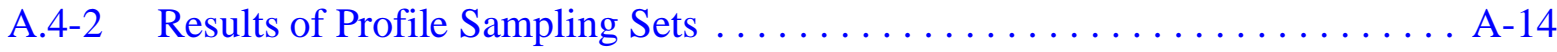

A.4-3 Results for Post-Operational Soil Samples. . . . . . . . . . . . . . . . . . A-19

A.4-4 Vegetation Sample Results. ...................... A-20

C.4-1 Sample Identification Examples...................... C-18

C.4-2 Sample Locations, Types, and Analyses ..................... C-19

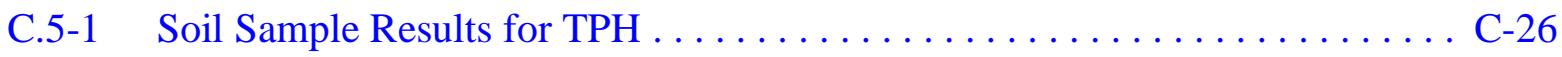

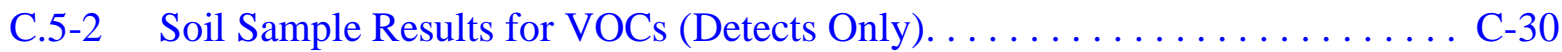

C.5-3 Soil Sample Results for SVOC (Detects Only) ................ C-34

C.5-4 Soil Sample Results for RCRA Metals $\ldots \ldots \ldots \ldots \ldots \ldots \ldots \ldots \ldots$ C-35

C.5-5 Soil Sample Results for Tritium...................... C-39 


\section{List of Tables (Continued)}

C.5-6 Soil Sample Results for TAL Metals (Except RCRA Metals) and Molybdenum, Boron, and Uranium . . . . . . . . . . . . . C-41

C.5-7 Soil Sample Results for Bromide, Chloride, Fluoride, Nitrates, Sulfate, and Cyanide (Detects Only) . . . . . . . . . . . . . . . . C-48

C.5-8 Soil Sample Results for Radium-226 and Radium-228 . . . . . . . . . . . . . . C-49

C.5-9 Soil Sample Results for TCLP Metals (Detects Only) . . . . . . . . . . . C-50

C.5-10 TCLP VOCs and SVOCs (Detects Only) . . . . . . . . . . . . C C-51

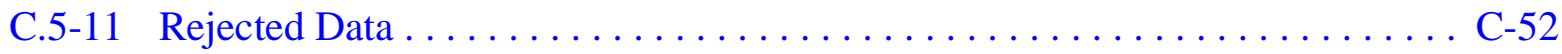

C.6-1 Known and Suspect Site Features $\ldots \ldots \ldots \ldots \ldots \ldots \ldots \ldots \ldots \ldots$

D.3-1 Potentially Complete Human Exposure Pathways at Gasbuggy . . . . . . . . . . D-5

D.3-2 RESRAD Parameters for Gasbuggy. . . . . . . . . . . . . . . D-9 


\section{List of Acronyms and Abbreviations}

AEC U.S. Atomic Energy Commission

ALARA As-low-as-reasonably-achievable

AOC Area(s) of concern

Ar-37 Argon-37

Ar-39 Argon-39

bgs Below ground surface

BLM U.S. Bureau of Land Management

C-13 Carbon-13

C-14 Carbon-14

CEDE Committed effective dose equivalent

CERCLA Comprehensive Environmental Response Compensation and Liability Act

CFR Code of Federal Regulations

CLP Contract Laboratory Program

CNF Carson National Forest

COPC Contaminants of potential concern

$\mathrm{CP} \quad$ Control Point

CRDL Contract-required detection limit

Cs-137 Cesium-137

CSM Conceptual Site Model

CV Coefficient of Variation

DOE U.S. Department of Energy

DOE/NV U.S. Department of Energy, Nevada Operations Office

DQO Data Quality Objective(s)

DRI Desert Research Institute

DRO Diesel-range organics

EIC Eberline Instrument Corporation 


\section{List of Acronyms and Abbreviations (Continued)}

EM Electromagnetic

EPA U.S. Environmental Protection Agency

EPNG El Paso Natural Gas Company

ERD Environmental Restoration Division

${ }^{\circ} \mathrm{F} \quad$ Degree(s) Farenheit

FEHM Finite Element Heat Mass Simulator

$\mathrm{ft} \quad$ Foot (feet)

$\mathrm{ft}^{2} \quad$ Square foot (feet)

GC Gas chromatography

GC/MS Gas chromatography/mass spectrometry

GPR Ground-penetrating radar

$\mathrm{gpd} / \mathrm{ft} \quad$ Gallon(s) per day per foot

GPS Global Positioning System

GRO Gasoline-range organics

HP Helicopter pad

HPLC High performance liquid chromatography

ICP Inductively coupled plasma

ICRP International Commission on Radiological Protection

IDW Investigation-derived waste

ILCR Incremental lifetime cancer risk

in. $\quad \operatorname{Inch}(\mathrm{es})$

IO Isolated occurrence

ITLV IT Corporation, Las Vegas Office

kt Kiloton(s)

Kr-85 Krypton-85

LCS Laboratory control sample 


\section{List of Acronyms and Abbreviations (Continued)}

LLD Lower limit of detectability

LLNL Lawrence Livermore National Laboratory

LQC Laboratory quality control

LRL Lawrence Radiation Laboratory

LTHMP Long-Term Hydrologic Monitoring Program

$\mathrm{m}^{2} / \mathrm{d} \quad$ Square meter(s) per day

$\mu \mathrm{g} / \mathrm{kg} \quad$ Microgram(s) per kilogram

md Millidarcie(s)

$\mathrm{mCi} \quad$ Millicurie(s)

$\mathrm{mg} / \mathrm{kg} \quad$ Milligram(s) per kilogram

$\mathrm{mg} / \mathrm{L} \quad$ Milligram(s) per liter

$\mathrm{mR} \quad$ Milliroentgen(s)

mrem Millirem(s)

mrem/yr Millirem(s) per year

MS Matrix spike

MSD Matrix spike duplicate

M\&TE Measurement and testing equipment

NCP National Contingency Plan

NCR Nonconformance Report

NEPA National Environmental Policy Act

NIST National Institute for Standards and Technology

NMAC New Mexico Administrative Code

NMED New Mexico Environment Department

NM OCD New Mexico Oil Conservation Division

NM QAPP New Mexico Quality Assurance Project Plan

NM WQCC New Mexico Water Quality Control Commission 


\section{List of Acronyms and Abbreviations (Continued)}

$\begin{array}{ll}\text { NRC } & \text { U.S. Nuclear Regulatory Commission } \\ \text { NTS } & \text { Nevada Test Site } \\ \text { NTSWAC } & \text { Nevada Test Site Waste Acceptance Criteria } \\ \text { NV ERP } & \text { Nevada Environmental Restoration Project } \\ \text { PAL } & \text { Preliminary Action Level(s) } \\ \text { PB } & \text { Preparation blank(s) } \\ \text { \%R } & \text { Percent recovery } \\ \text { PCB } & \text { Polychlorinated biphenyl(s) } \\ \text { pCi/g } & \text { Picocurie(s) per gram } \\ \text { pCi/mL } & \text { Picocurie(s) per milliliter } \\ \text { pCi/L } & \text { Picocurie(s) per liter } \\ \text { PHS } & \text { U.S. Public Health Service } \\ \text { PID } & \text { Photoionization detector } \\ \text { ppm } & \text { Part(s) per million } \\ \text { PRG } & \text { Preliminary remediation goal(s) } \\ \text { psi } & \text { Pound(s) per square inch } \\ \text { QA } & \text { Quality assurance } \\ \text { QAC } & \text { Quality Assurance Coordinator } \\ \text { QAPP } & \text { Quality Assurance Project Plan } \\ \text { QC } & \text { Quality control } \\ \text { RAMS } & \text { Remote area monitoring system } \\ \text { RESRAD } & \text { Residual Radioactivity } \\ \text { RCRA } & \text { Resource Conservation and Recovery Act } \\ \text { RME } & \text { Reasonable maximum exposure } \\ \text { RPD } & \text { Relative percent difference } \\ \text { RTP } & \text { Recording Trailer Park } \\ & \end{array}$




\section{List of Acronyms and Abbreviations (Continued)}

\begin{tabular}{ll} 
SF & Slope factor \\
Sr-90 & Strontium-90 \\
SGZ & Surface Ground Zero \\
SSHASP & Site-specific health and safety plan \\
STALLKAT & System to analyze low levels of krypton and tritium \\
SVOC & Semivolatile organic compounds \\
TAL & Target Analyte List \\
TCLP & Toxicity Characteristic Leaching Procedure \\
TEDE & Total effective dose equivalent \\
TLD & Thermoluminescent dosimeter \\
TOUGH2 & Transport of unsaturated groundwater heat simulator \\
TPH & Total petroleum hydrocarbons \\
TVD & Total vertical depth \\
USFS & U.S. Forest Service \\
USFWS & U.S. Fish and Wildlife Service \\
UST & Underground storage tank \\
VOA & Volatile organic analyses \\
VOC & Volatile organic compounds \\
Xe-133 & Xenon-133 \\
$<$ & Less than \\
\hline
\end{tabular}




\subsection{Introduction}

The scope of this work plan is to document the environmental sample collection objectives and the proposed technical site investigation strategies that will be utilized during the Gasbuggy Site characterization.

Project Gasbuggy was the first of three joint government-industry experiments conducted under the Plowshare program to test the effectiveness of nuclear explosives to fracture low-permeability natural gas reservoirs to stimulate production. Gasbuggy consisted of one 29-kiloton (kt) nuclear device (DOE/NV, 1994b) emplaced in a boring at a depth of 4,240 feet (ft) below ground surface (bgs) in the Pictured Cliffs sandstone formation and detonated on December 10, 1967 (AEC, 1971). The Gasbuggy Site is located approximately 55 air miles east of Farmington, New Mexico, in Rio Arriba County within the Carson National Forest (Figure 1-1). Six major natural gas production tests were conducted after reentry drilling was completed in January 1968. Long-term production testing was completed in November 1973 and pressure monitoring activities were completed in late 1976 (DOE/NV, 1978).

Site restoration activities were conducted in August and September 1978, and included well plugging and abandonment, decontamination and disposal of equipment, and soil sampling and analysis. No soil or soil moisture samples collected during the 1978 restoration exceeded established release criteria for radioactivity; therefore, no soil remediation was required (DOE/NV, 1983).

\subsection{Purpose}

Although previous characterization and restoration activities were performed for the surface and shallow subsurface ( $<20 \mathrm{ft}$ bgs), there was not formal closure of the site. In addition, these efforts did not adequately address the potential for chemical contamination at the surface/shallow subsurface. Additionally, the subsurface hazards have not been evaluated for potential migration outside of the current site subsurface intrusion restrictions. The goal of this environmental investigation at the Project Gasbuggy Site is to collect data of sufficient quantity and quality to establish current site conditions, and to use the data to identify and evaluate if further remedial action is required to achieve permanent closure of the site that is protective of human health and the environment. This 


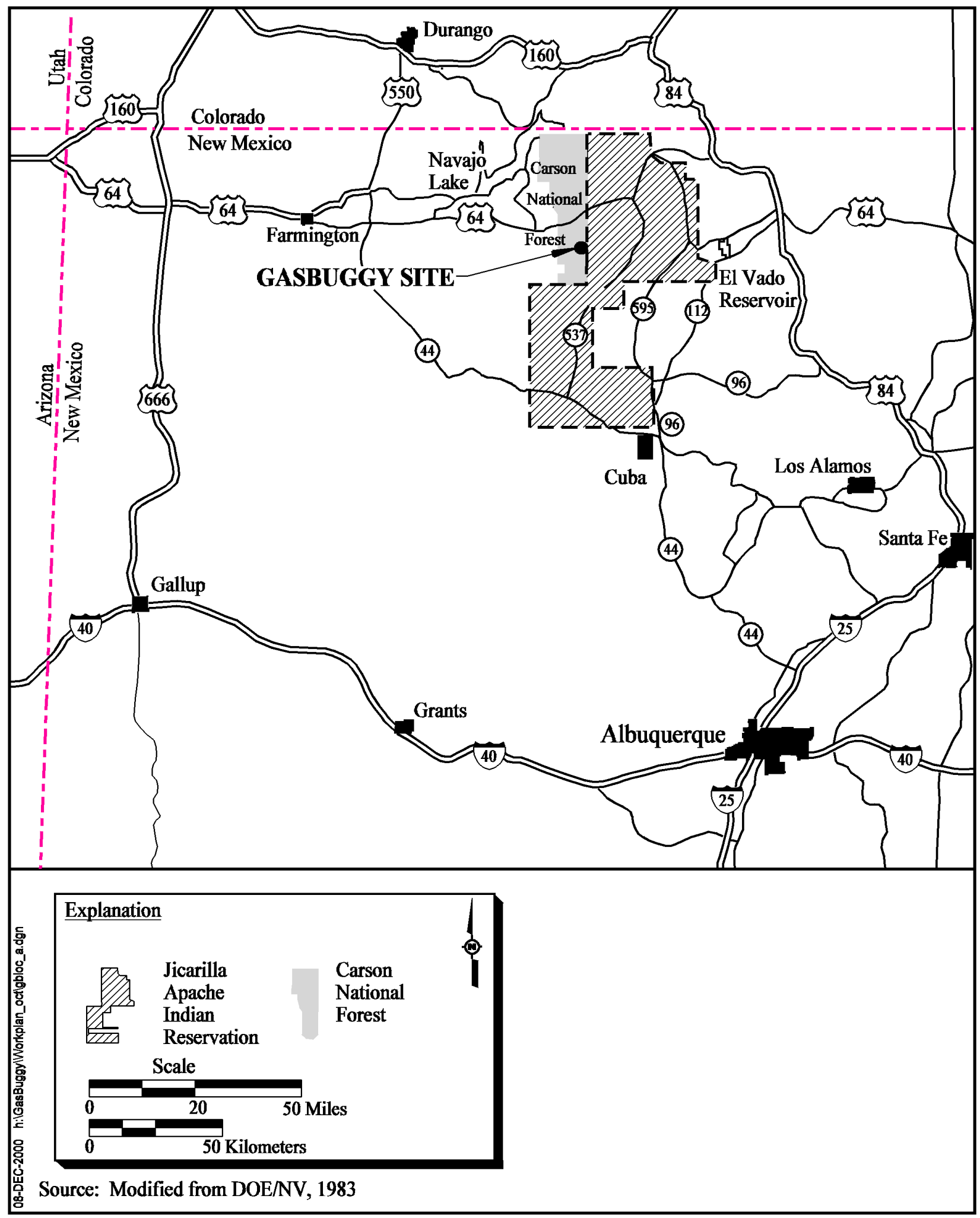

Figure 1-1 
investigation will utilize available data, documented historical knowledge, and process knowledge from similar sites, to the extent possible. Historical and/or new data collected will be of sufficient quantity and quality to be used in addressing the following data quality objectives (DQOs), as required:

- Determine the nature and extent of potential contamination at the surface/shallow subsurface.

- Support a risk-based decision on the need to perform corrective actions for the surface/shallow subsurface.

- Support a corrective action alternative analysis for the surface/shallow subsurface.

- Support the use of subsurface transport models to determine if future resource development could impact the extent of subsurface contamination.

- Determine if existing subsurface intrusion restrictions need to be adjusted to ensure they are protective of human health and the environment.

\subsection{Scope of Work}

The details of the scope of work are divided into two sections: the Surface and Shallow Subsurface Work Plan (Section 4.0), and the Subsurface Work Plan (Section 5.0).

In order to complete the scope of work for the Gasbuggy investigation, the following activities have been or will be carried out: a surface geophysical investigation, surface/shallow subsurface sampling, sampling of an on-site deep groundwater monitoring well and development of a deep subsurface transport model.

The first portion of the investigation consisted of researching historical documents, photos, diagrams, and engineering drawings. The objective of this research was to identify suspect areas and corresponding contaminants of potential concern (COPCs), correlate the suspect areas with their actual locations at the Gasbuggy Site, and identify historical data gaps.

The second portion of the surface/shallow subsurface investigation consisted of a preliminary field investigation. This work, completed in August and September of 2000, consisted of a surface geophysical investigation and a preparative soil sampling effort. The geophysical investigation included surveys to accurately identify and place shallow subsurface features. The results of the 
geophysical investigation coupled with historical records were used to identify and delineate potential areas of concern (AOCs), from which shallow subsurface soil samples were collected. The results of the preliminary field investigation were used to identify remaining data gaps. Further field surface/shallow subsurface investigations will concentrate on filling the remaining data gaps.

Additional investigation for the surface/shallow subsurface will consist of (1) collecting additional soil samples to fill data gaps and define the nature and extent of potential contamination in each AOC; (2) determining if there is a potential path for COPCs to migrate to shallow groundwater; and (3) determining the nature and extent of potential contamination in the shallow groundwater, if applicable. Background conditions will be established by collecting soil samples and shallow groundwater samples, if applicable, at nonimpacted areas near the site.

The subsurface investigation will include sampling of a deep groundwater monitoring well on site and development of a deep subsurface transport model. The groundwater monitoring well will be sampled to provide additional data on the source of low-level radiological contamination in the well, and to provide information for plugging and abandoning the well. The modeling effort will result in a conceptual model of flow and transport of deep subsurface contamination. The model will focus on the natural gas reservoir in the area of the Gasbuggy test site. Although a deep aquifer exists within the Ojo Alamo Formation under the Gasbuggy Site, existing data are sufficient to determine the absence of risk in this aquifer as an exposure pathway. This aquifer will only be investigated as a potential transport pathway.

The subsurface modeling effort will consist of locating and evaluating subsurface data, and identifying numerical models capable of handling the necessary physical processes involved. Once the numerical model of flow and transport under current conditions is developed, stressed conditions simulating nearby gas production wells will be applied. Results of the model will be evaluated to determine if existing subsurface intrusion restrictions are sufficient to protect human health and the environment, with consideration of uncertainty. 


\subsection{Investigation Work Plan Contents}

This document provides a detailed description of past and present site conditions, a description of the DQO process results, and a description of the methods and procedures to be used for future investigation activities. This work plan has been organized as follows:

- Section 1.0 - Introduction

- Section 2.0 - Facility Description

- Section 3.0 - Data Quality Objectives

- Section 4.0 - Surface and Shallow Subsurface Work Plan

- Section 5.0 - Subsurface Work Plan

- Section 6.0 - Schedule

- Section 7.0 - References

- Appendix A - Gasbuggy Historical Radiological Monitoring and Sampling Results

- Appendix B - New Mexico Quality Assurance Project Plan (NM QAPP)

- Appendix C - Results of Gasbuggy Preliminary Field Investigation (August and September, 2000)

- Appendix D - Gasbuggy Site Surface Radiological Dose/Risk Assessment

Measurements are presented in English units except where data was specifically measured in metric units. 


\subsection{Facility Description}

\subsection{Physical Setting}

This section describes the location of the Gasbuggy Site, land status, and environmental setting which includes topography, vegetation, and description of the surface waters, wetlands, and floodplains present at the Gasbuggy Site.

\subsubsection{Land Status}

The Gasbuggy Site is located within the Carson National Forest (CNF), Jicarilla Ranger District. The CNF currently supports multiple uses including recreation, livestock grazing, and resource development.

The project installations consist of the surface ground zero (SGZ) area, the Well GB-D area, the recording trailer park (RTP), the control point (CP), and the helicopter pad (HP) (see Figure 2-1). The use of these lands for Project Gasbuggy was established in a Memorandum of Understanding, dated March 23, 1967, between the U.S. Department of Agriculture's U.S. Forest Service (USFS) and the U.S. Atomic Energy Commission (AEC) (predecessor to the U.S. Department of Energy [DOE]).

Additionally, by land withdrawal action of Public Land Order 4332, dated June 22, 1967, the U.S. Department of the Interior, Bureau of Land Management (BLM) withdrew from all forms of appropriation, including mining and mineral leasing laws, and reserved for use by the AEC the surface and subsurface of lands within Section 36, Township 29 north, Range 4 west, New Mexico Principal Meridian. Surface and subsurface operating rights to lands within the southwest $1 / 4$ of the described section were reserved for the use of the AEC under stipulations of Contract AT(04-3)-711, dated January 31, 1967, signed by the AEC, U.S. Department of Interior, and the El Paso Natural Gas Company (EPNG) (DOE/NV, 1983). It should be noted that of the five operational areas, only the SGZ area is within this $1 / 4$ section. The Well GB-D area is outside of this $1 / 4$ section, although still in Section 36, and the RTP, CP, and HP are outside of Section 36. 


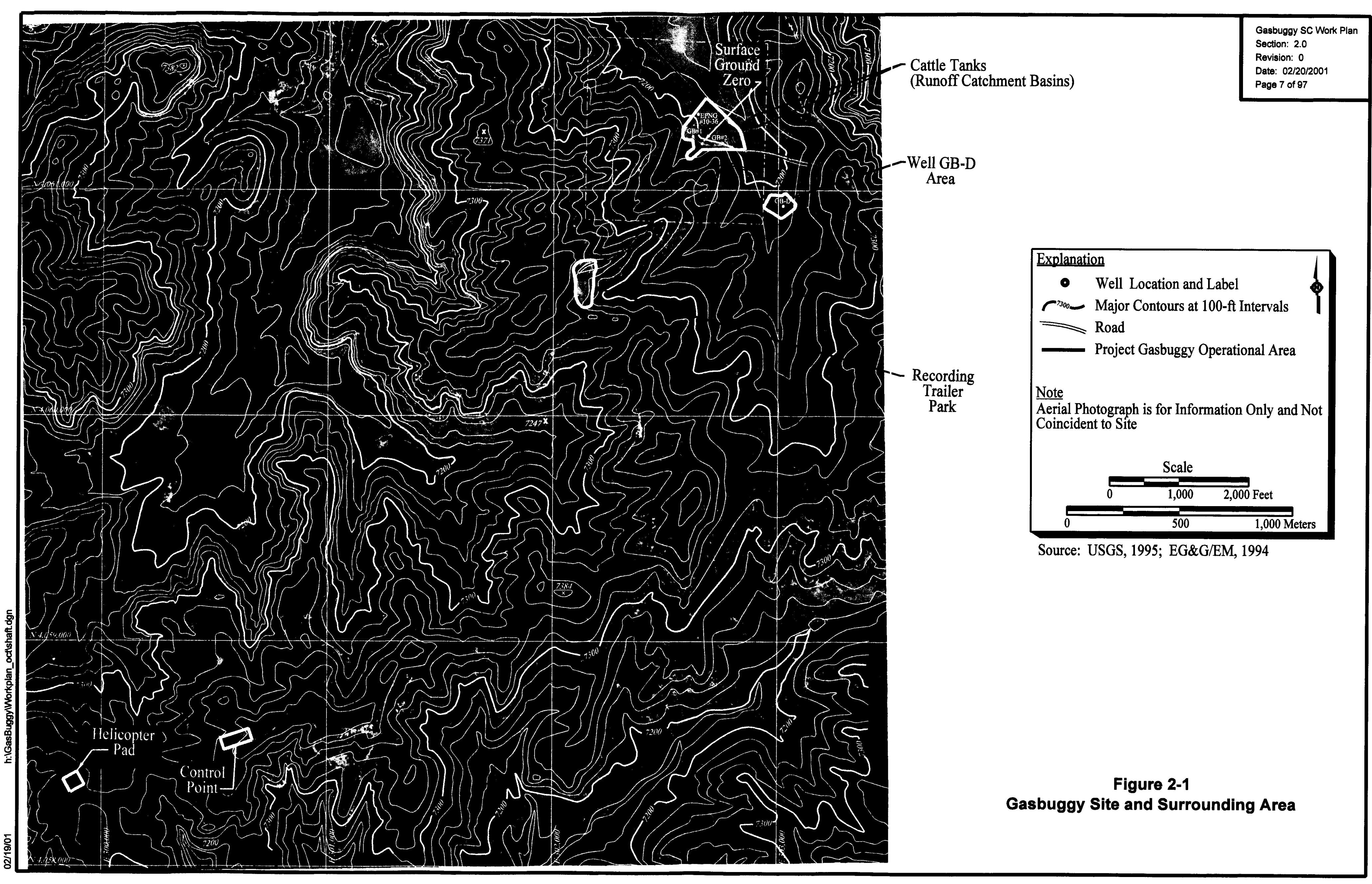


For the purposes of the work plan, the Gasbuggy Site is defined as the SW 1/4 section of Section 36, Township 29 north, Range 4 west, and disturbed areas outside these boundaries (i.e., Well GB-D area, RTP, CP, and HP), which were impacted by DOE operations.

A plaque at SGZ states the current subsurface intrusion (drilling) restrictions as: no intrusion is allowed from the surface to $1,500 \mathrm{ft}$ total vertical depth (TVD) within a $100 \mathrm{ft}$ radius, and no intrusion is allowed from 1,500 to 4,500 ft TVD within a 1,600 ft radius (DOE/NV, 1978).

\subsubsection{Environmental Setting}

The Gasbuggy Site is located in the northeast portion of the San Juan Basin, a structural feature of the Colorado Plateau Province covering northwestern New Mexico and southwestern Colorado. The Gasbuggy Site is surrounded by typical canyon and plateau topography of the Colorado Plateau Province. Elevations range from 6,800 to 7,500 ft in the surrounding area, and from 7,000 to 7,300 ft in the immediate test area (DOE/NV, 1988). Surface ground zero is located at an elevation of 7,211 ft above sea level (DOE/NV, 1983). Figure 2-1 is a topographical map of the Project Gasbuggy location and surrounding area.

The Gasbuggy Site lies within the Cold Temperate climatic zone. Three basic vegetation communities (i.e., forest, scrubland, and grassland) are represented at the site. The forest community is classified as Rocky Mountain Montane Conifer Forest, which is dominated by Ponderosa pine. This community is typically found along the steeper slopes of the site, forming a band around the drainage areas. The scrubland community is Great Basin Montane Scrub and is found along hilltops, above the forest. Although classified as a scrubland, this community may support Ponderosa and Pinyon pines. The grassland community is further subdivided into two distinct series, the Great Basin Shrub-Grassland, Sagebrush Grass Series, and the Great Basin Shrub-Grassland, Wheatgrass Series (DOE/NV, 1993d).

Based on site surveys completed in 1993, the SGZ area and Well GB-D area are within the Grassland communities (DOE/NV, 1993d). Based on interpretation of aerial photos taken in 1994 (EG\&G/EM, 1994), the RTP, CP, and HP are located within artificially cleared areas in either the forest or scrubland communities. 


\subsubsection{Surface Water, Wetlands, and Floodplains}

The Gasbuggy Site has no naturally standing water, streams, springs, or seeps. A survey of state wetland inventories and the flood insurance map for Rio Arriba County did not indicate either wetlands or floodplain areas occurring at the Gasbuggy Site (DOE/NV, 1993e). However, during a site survey conducted in 1993, it was noted that there are four artificially created seasonal ponds within the vicinity of the Gasbuggy Site. Three are constructed cattle tanks and one is the result of water ponding at the upstream end of a culvert under the elevated main access road (DOE/NV, 1993b). Two of the cattle tanks and the berms used to construct them are visible east of SGZ in the 1994 aerial photo of the site (EG\&G/EM, 1994) provided in Figure 2-1. The survey also concluded that the areas within the drainage channels upstream of the bermed tanks, the area upstream of the elevated road, as well as the center of the drainage channel, should be considered as a floodplain area (DOE/NV, 1993b). No field work is currently proposed in these areas.

\subsubsection{Geology and Hydrology}

The Gasbuggy Site is situated in the San Juan Basin, a large structural basin containing approximately $12,000 \mathrm{ft}$ of sedimentary rocks. The natural contour of the site slopes northeast into Leandro Canyon. Leandro Canyon is an ephemeral drainage and tributary of the ephemeral La Jara Creek.

The surficial alluvium, the San Jose Formation, the Nacimiento Formation, and the Ojo Alamo Sandstone are the principle aquifers in the Gasbuggy area. A detailed discussion of the geology and hydrology, as they relate to the subsurface investigation, is presented in Section 5.0. The Nacimiento and San Jose Formations are continental flood plain deposits and are the predominant surface formations in the Gasbuggy area. They comprise a 3,500 ft sequence of fine- to medium-grained, locally conglomeratic sandstone, interbedded with claystone- and sandy-variegated shale. The beds of sandstone commonly contain water throughout the central San Juan Basin (DOE/NV, 1988).

Descriptions documented during the preliminary field investigation indicate the shallow stratigraphy is dominated by poorly graded, red-brown to brown silty sand, poorly graded sand, and silt, to a minimum of $30 \mathrm{ft}$ bgs. Weathered sandstone bedrock was encountered between 14 to $24 \mathrm{ft}$ bgs in the northwest portion of the SGZ area. 
Depth to the shallow groundwater table at the Gasbuggy Site has not been established. Prior to the Gasbuggy experiment, wells within a 10 miles radius of SGZ were inventoried. The 13 wells inventoried range in depth from 54 to $229 \mathrm{ft}$, and the depth to the water in the wells ranges from 22 to $174 \mathrm{ft}$ bgs. The shallow wells were completed in the alluvium, which occurs in the valleys of the intermittent streams draining the area. The deeper wells tap either the lower part of the alluvium or the underlying sandstones (Mercer, 1968). The alluvial areas are not contiguous throughout the area; therefore, the water level in these wells may not be representative of conditions at the Gasbuggy Site. Shallow groundwater was not encountered during the preliminary field investigation. The maximum depth of any boring during the preliminary field investigation was $36 \mathrm{ft}$ bgs.

\subsection{Operational History}

Project Gasbuggy was the first of three United States underground nuclear experiments for the stimulation of low-productivity natural gas reservoirs. The other two sites are the Project Rulison Site and the Project Rio Blanco Site, both in Colorado. Information from characterization efforts at these sites, as well as other underground test area investigations, has been used in conjunction with historical documentation to determine potential AOCs and chemical and radiological COPCs.

The following five Project Gasbuggy operational areas will be discussed in more detail in the following sections (Figure 2-1):

- $\quad$ Surface Ground Zero

- Well GB-D

- Recording Trailer Park

- Control Point

- Helicopter Pad

Based on available historical documentation, no chemical release sites other than the mud pits were identified. Additionally, there was no material buried at the Gasbuggy Site other than drilling fluids and construction debris. Process knowledge as documented in Appendix A indicates the only radiological releases at the site surface consisted of short-lived radioactive gases and tritium. Except as otherwise noted, all operational support equipment and infrastructure were removed from the site as part of the site restoration activities in 1978. 


\subsubsection{Surface Ground Zero Area}

This area is irregularly shaped and approximately 8 to 10 acres in size (Figure 2-1). Prior to AEC/DOE activities, a single natural gas-producing well existed at the site. This well, EPNG 10-36 (also referred to as San Juan 29-4, Unit \#10-36, or Well 29-4, No. 10, in other documents), had been in production for approximately 10 years. This well was converted to a groundwater monitoring well for the Ojo Alamo aquifer in 1968 (AEC, 1971) and was purchased by the DOE from the EPNG Co. in 1978. The SGZ area also includes four other wells. Two test wells (i.e., wells GB-1 and GB-2) were drilled prior to the nuclear detonation to test the geologic formations. Well GB-2 was reentered after the detonation and renamed Well GB-2R to signify this reentry. A third well, Well GB-E, was used as the emplacement well. This well was also reentered after the detonation and renamed Well GB-ER. A fourth well, Well GB-3, was drilled after the detonation to test changes in the geologic formations.

There were several phases of AEC/DOE activities at the SGZ area. Predetonation activities included construction and drilling in 1967. Postdetonation activities included reentry into several of the project wells in late 1967 and throughout 1968, gas production experiments from 1968 to 1973, and pressure monitoring until 1976. Site restoration was conducted in 1978.

The AOCs are identified as bold, italic text in the following paragraphs. These AOCs will be referred to in later parts of this by the names indicated.

\section{Construction and Drilling}

Based on historical aerial photographs, at least one sump/mud pit associated with Well EPNG 10-36 was constructed and used prior to Project Gasbuggy (see Figure 2-2). It is unclear if this sump/mud pit (Well EPNG 10-36 Sump) was used during Project Gasbuggy or if later mud pits may have been constructed overlapping this pit. Based on historical photos, this pit remained open during the drilling of Well GB-E, but was closed sometime prior to the detonation. Identified sumps/mud pits that can be determined to have been closed prior to DOE's use of the site will not be addressed by this investigation.

Based on a SGZ area site plan dated May 26, 1967 (Figure 2-3), prior to initiation of drilling the emplacement well, two mud pits were constructed to contain fluids from the drilling of wells GB-1 


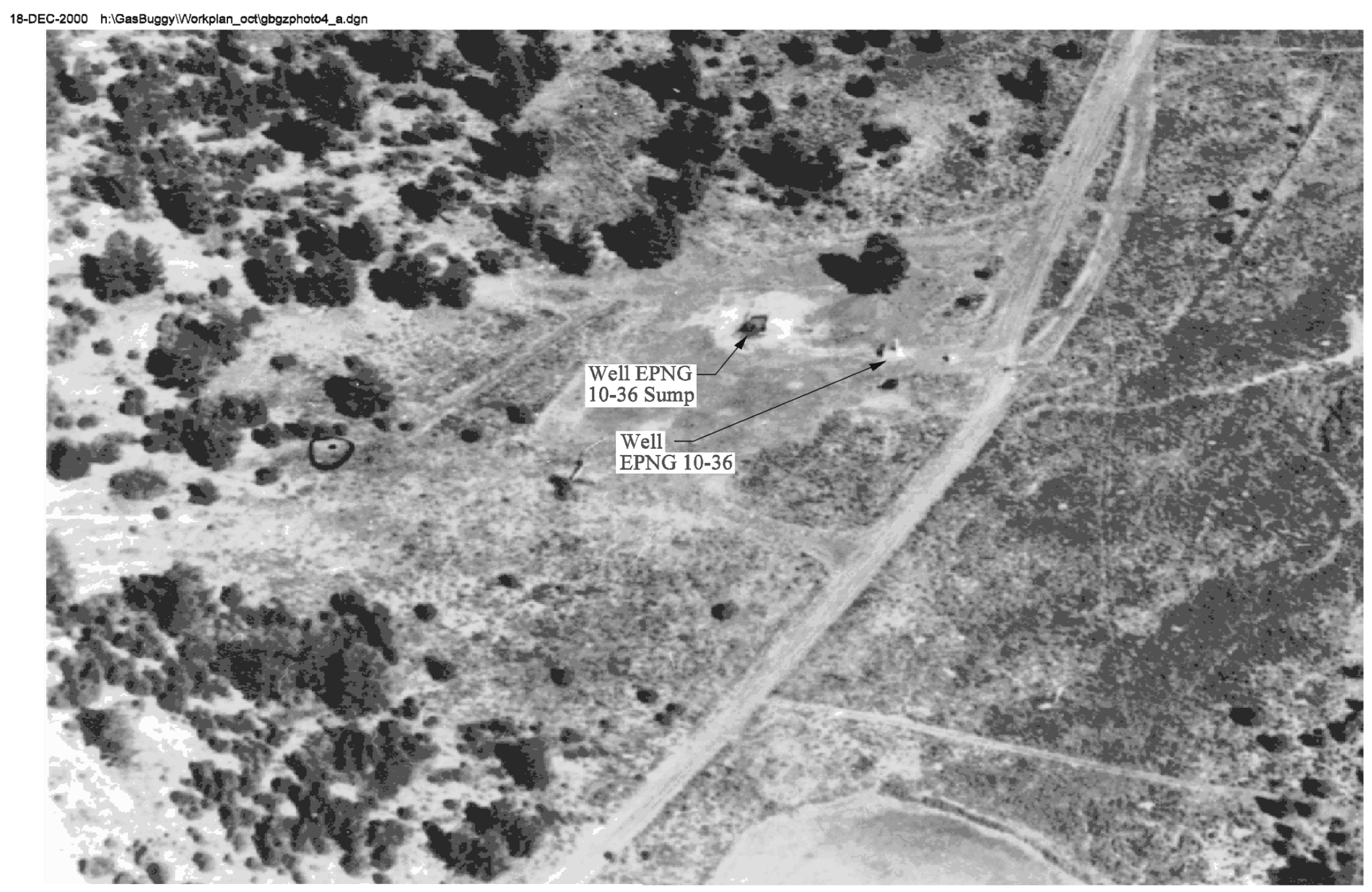




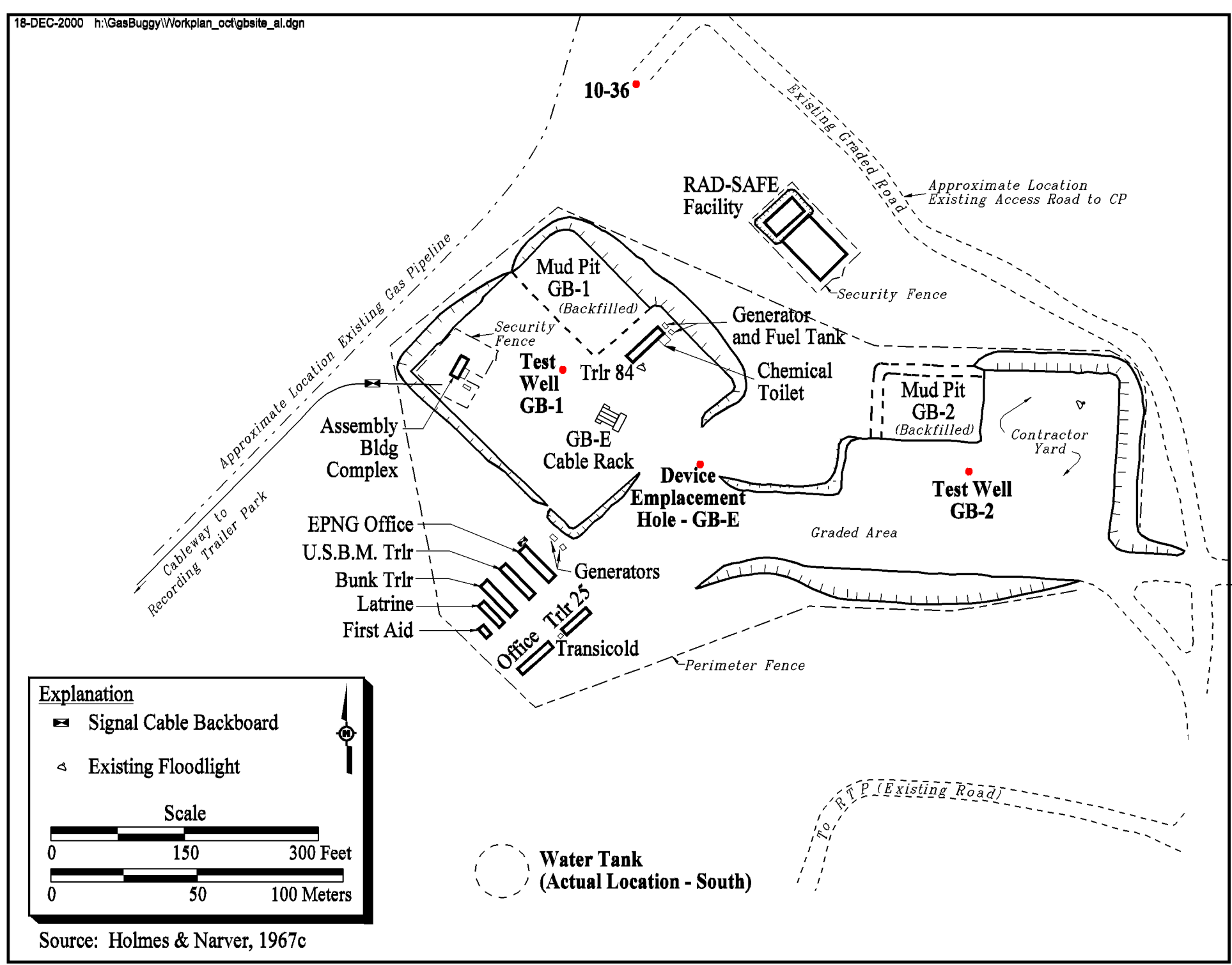

Figure 2-3

Surface Ground Zero Site Plan Gasbuggy, New Mexico 
and GB-2. According to the drawing, these mud pits (Well GB-1 Mud Pit and Well GB-2 Mud Pit) were backfilled prior to commencement of drilling Well GB-E on June 25, 1967 (AEC, 1971).

Based on interpretation of photographs taken during the drilling of Well GB-E, up to five additional mud pits were constructed to contain fluids from this well. Figure 2-4 shows the large reserve mud pit (Well GB-E Mud Pit A). Also visible in this picture are two smaller features, which are assumed to be mud pits (Well GB-E Mud Pit B and Well GB-E Mud Pit $\boldsymbol{C}$ ) used during drilling of Well GB-E, but may be surface depressions which have caught rainwater. Based on the site drawings and photographs, Well GB-E Mud Pits B and C were likely constructed partially on top of the Well GB-1 Mud Pit. Figure 2-5 shows a small surface impoundment assumed to be a mud pit (Well GB-E Mud Pit $\boldsymbol{D})$ at the base of the fill used to construct the contractor's yard. This position appears to be the same as the mud pit for Well GB-2, as indicated in Figure 2-3. Figure 2-6 is a photograph taken on the day of the detonation. This photograph shows a trench (Well GB-E Mud Pit E) described in historical documentation as a mud pit (Wofford, 2000a).

Based on interpretation of daily drilling logs and available photographic documentation, it appears that the main drilling mud pits were backfilled with native soil beginning on or around November 12, 1967, when drilling was suspended in order to make preparations for placing the nuclear device in the well (F\&S, 1968). The soil used for backfilling appears to have come from the east side of the main road, as evidenced by the surface scrapings that are apparent in Figure 2-6 and Figure 2-7. During stemming operations, initiated on November 18, 1967, and continued through December 9, 1967, it was necessary to pump large amounts of water from the emplacement hole (F\&S, 1968). It is assumed this water and possibly cement and grout from stemming operations were pumped into the trench shown in Figure 2-6.

The historical documentation does not indicate where mud pits for Well GB-3 were constructed.

Other potential sources of contamination in the SGZ area include product storage areas, potential releases, septic tanks, potential landfills, and potential laboratory facilities. One potential landfill (Landfill $\boldsymbol{E}$ ) used during drilling is evident in Figure 2-5. It appears this landfill was used for construction debris. The location(s) of on-site laboratories are not known. 


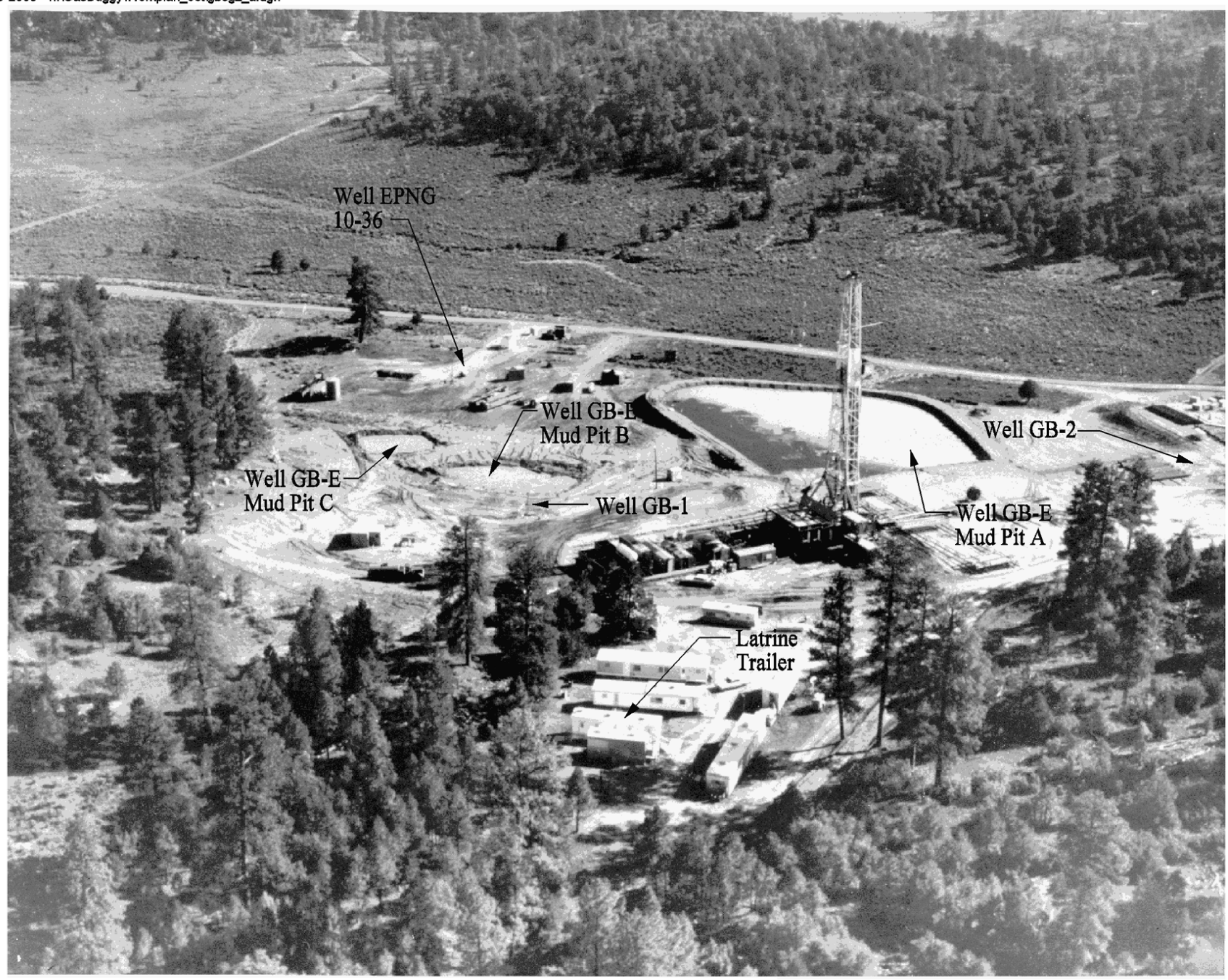

Figure 2-4

Oblique Photograph of Surface Ground Zero Area During Drilling of Well GB-E 


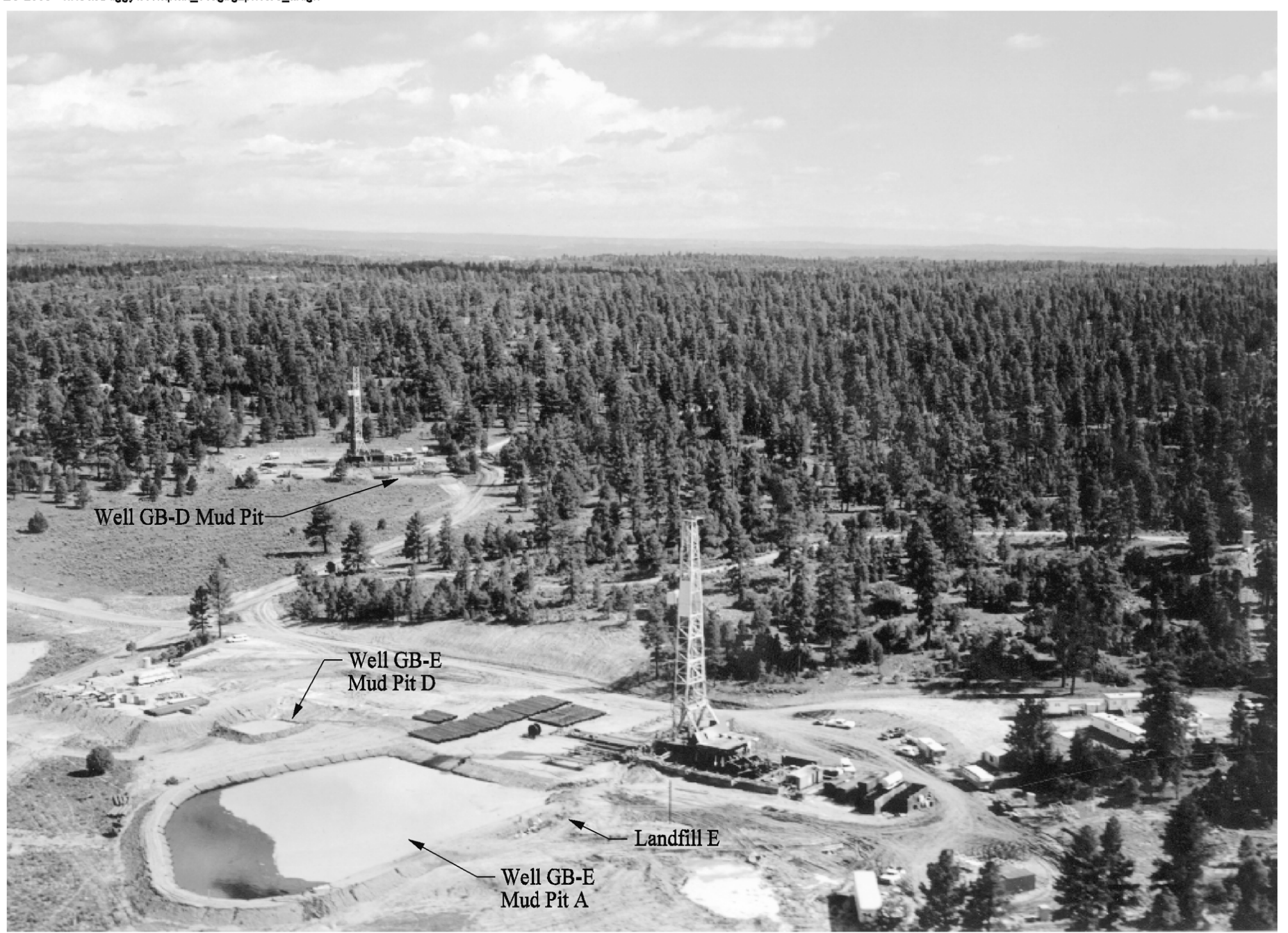


18-DEC-2000 h:IGasBuggyiWorkplan_octlgbgzphoto_a.dgn

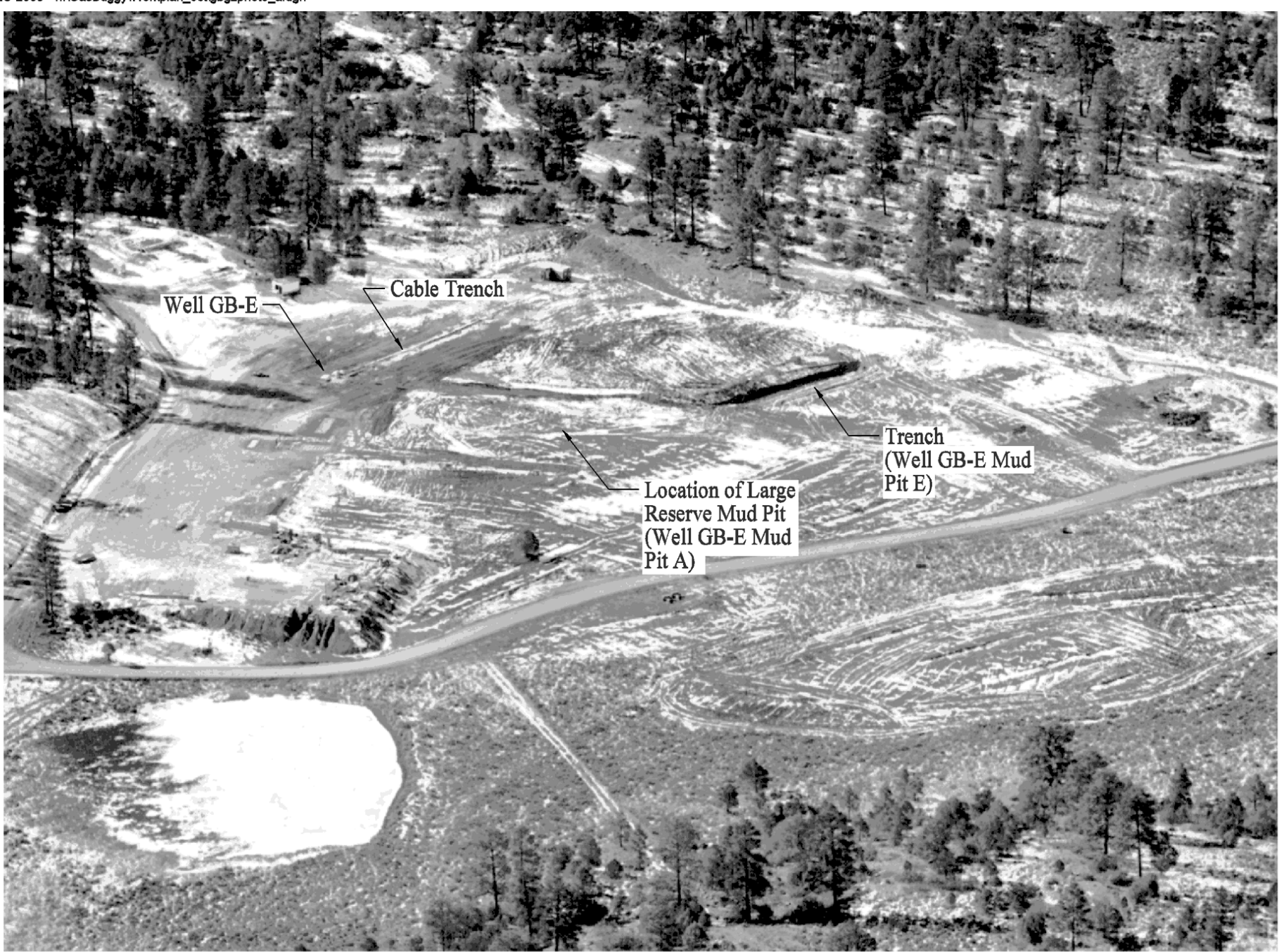

Figure 2-6

Oblique Photograph of Surface Ground Zero Area December 10, 1967 
18-DEC-2000 h:IGasBuggy|Workplan_octlgbgzphoto2_a.dgn

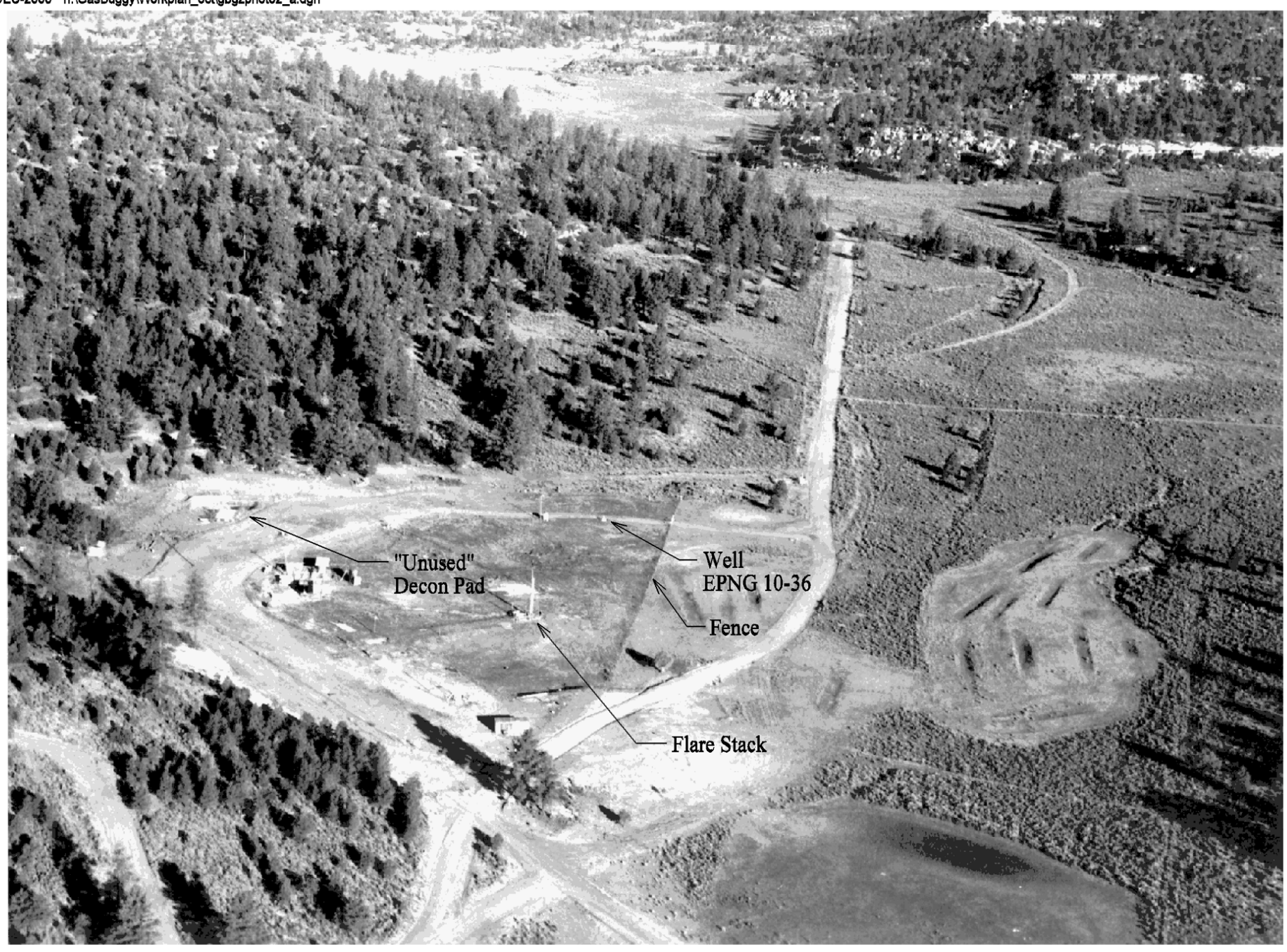

Source: Wofford, 2000a

Note: View is to the North,

Date of Photograph is Unknown

Figure 2-7

Oblique Photograph of Surface Ground Zero Area Prior to Restoration 
The locations of two septic tanks are shown in Figure 2-8. Neither this diagram or any other documentation found indicates the engineering of the tanks. The septic tank shown in Figure 2-8 in the southwestern corner of the site (Septic Tank A) corresponds with the location of the latrine trailer, as shown in Figure 2-3 and Figure 2-4. The historical documentation does not indicate what the septic tank near Well GB-E (Septic Tank B) was used for, nor can any inferences be made based on historical site photographs or diagrams.

\section{Detonation}

The detonation itself had little or no impact on the surface. Discussions on the subsurface impacts of the investigation are provided in Section 5.0.

\section{Post-Detonation Operations}

Post-detonation operations in the SGZ area included reentry drilling and gas production. Reentry of Well GB-ER was begun on December 13, 1967. On January 10, 1968, at a depth of 3,097 ft (333 ft above the detonation point), communication with the chimney (i.e., zone of fractured rock above the detonation point) was established. Reentry drilling was also conducted in Well GB-2R and Well EPNG 10-36. Well GB-2R was completed to a depth of 4,224 ft; however, the hole apparently collapsed and prevented the use of the hole for production testing. The stemming was removed from Well EPNG 10-36 to a depth of 3,612 ft, where casing damage prevented further penetration. The well was then completed in the Ojo Alamo sandstone formation as an aquifer monitoring well (DOE/NV, 1988). Well GB-3 was drilled to a depth of 4,800 ft to investigate changes to the subsurface.

Based on available documentation, it is unclear where drilling wastes generated during reentry drilling and initial drilling of Well GB-3 were disposed. Initial reentry drilling of Well GB-ER was done by gas circulation. At a depth of 3,260 ft bgs, it became necessary to use drilling mud. According to daily drilling reports, mud was placed in polyethylene-lined mud pits and sampled (F\&S, 1968). Sample results were unavailable; however, based on the documentation reviewed in Appendix A, it is assumed no radioactivity other than potentially tritium and short-lived radioactive gases was found. 


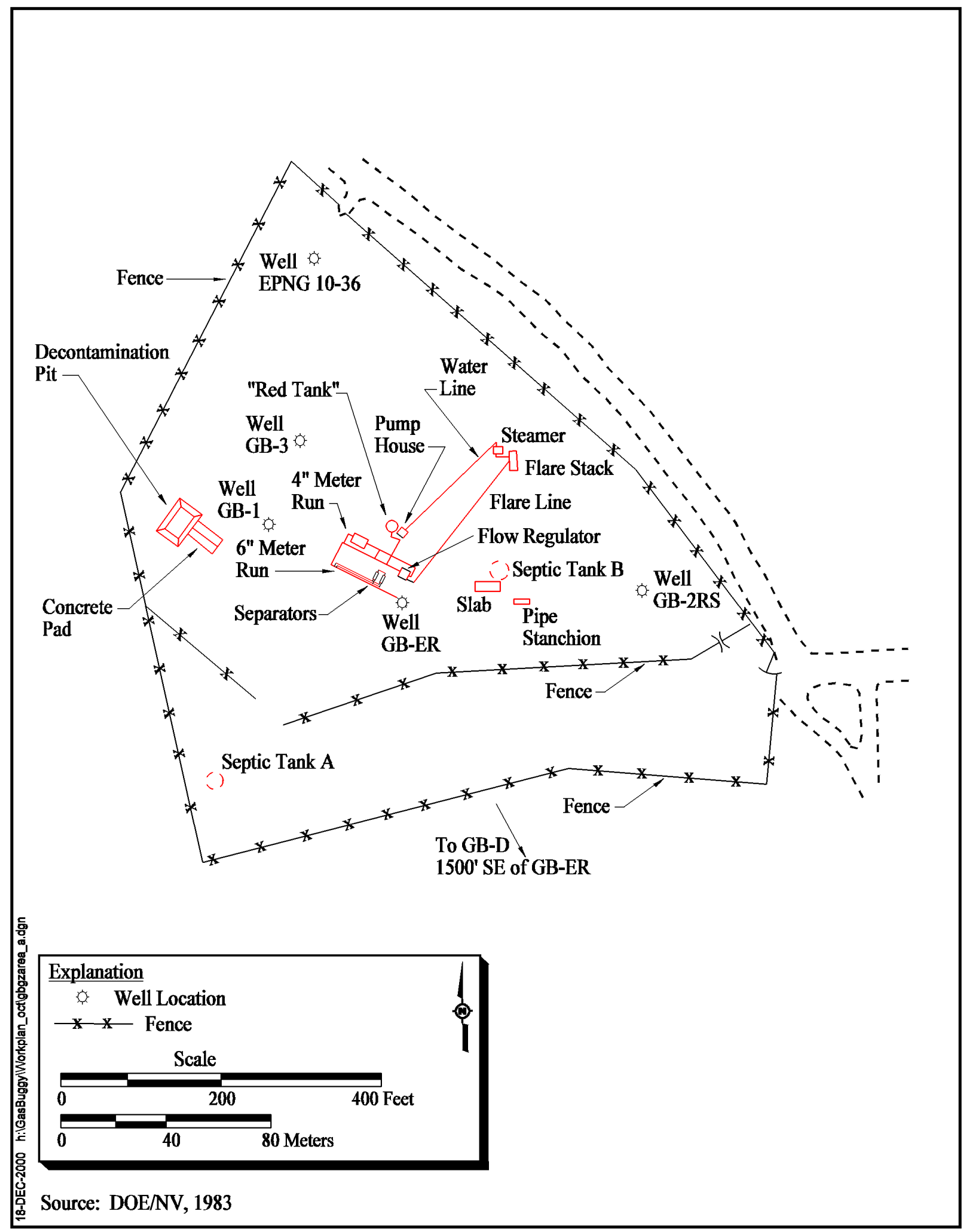

Figure 2-8

Surface Ground Zero Area Status as of December 1976 
Six major natural gas production tests were conducted, two in 1968, three in 1969, and one in 1973. These tests are known to have brought water, natural gas, and a small amount of oil to the surface, as well as tritium and short-lived radioactive gases (DOE/NV, 1988). During the early production tests, fluids were separated from the gas prior to flaring, containerized, and shipped to the Nevada Test Site (NTS) for disposal. However, the amount of water generated in later tests made this method of disposal impractical. In order to dispose of the large quantities of water produced, the water was first separated from the gas, turned into steam, and then injected into the gas flare (DOE/NV, 1988). This process contaminated the soil in the SGZ area with low-levels of tritium (see Appendix A).

\section{Site Restoration Operations}

Figure 2-7 shows the SGZ area as it appeared prior to the 1978 site restoration. The exact date of this photo is not known but appears to have been taken during either the 1968/1969 or 1973 production testing. Site restoration activities were conducted over a six-week period in August and September 1978. Restoration activities included: (1) well plugging and abandonment; (2) decontamination, transport, and disposal of equipment; (3) packaging, transport, and disposal of solid and liquid waste; (4) land surface restoration; and (5) final status sampling and analysis. None of the soil samples collected during the 1978 restoration activities exceeded established release criteria; therefore, no soil was remediated. In addition, no radioactive waste was buried on site (DOE/NV, 1983). For details pertaining to the radiological surveillance program and sampling efforts during the 1978 restoration, refer to Appendix A.

Decontamination of equipment was conducted on a large metal decontamination pan designed to collect the decontamination fluids. Decontamination during the restoration was completed without the use of solvents. Items that could not be decontaminated were shipped to the NTS for disposal as low-level radioactive waste. All decontamination fluid was recaptured and either injected into the Gasbuggy cavity or vaporized and released into the atmosphere (DOE/NV, 1983).

The Project Gasbuggy Well Plugging and Site Restoration Plan (DOE/NV, 1978) and the Project Gasbuggy Site Restoration Final Report (DOE/NV, 1983) state that all septic tanks were to be backfilled. The site restoration final report states that Septic Tank A was backfilled; however, there is no documentation verifying that this was accomplished for Septic Tank B. It is possible this tank may not have existed. 
Engineering drawings (Figure 2-3) show a decontamination pad ("labeled as RAD-Safe Facility") in the central part of the SGZ area. There is no evidence that this pad was ever built. However, "as-built" drawings show the decontamination pad near the western edge of the SGZ area, as shown in Figure 2-8. This location is also supported by historical photographs (Figure 2-7) in which the pad is visible in the western edge of the site. Documentation in the closure reports (EIC, 1979, and DOE/NV, 1983) indicate this pad was never used. This is supported by the fact there was no radiological contamination (other than tritium) of equipment during the project, thus little need for decontamination. During site restoration activities, this decontamination pad and liner were broken up; the depression formed by its removal was enlarged; and the concrete, asphalt, and plastic of the pad were placed into the excavation. Other broken up concrete pads were also placed into the excavation. The excavation was then backfilled with approximately $3 \mathrm{ft}$ of cover (Landfill B) (DOE/NV, 1983) (see Figure 2-9). Analysis of soil samples taken in the decontamination pad sump area as well swipe samples of the decontamination pad liner and concrete pads taken prior to burial indicated concentrations of tritium were less than the lower limit of detectability (LLD).

Five wells (i.e., wells GB-1, GB-2R, GB-3,GB-D and GB-ER) were plugged and abandoned in place. The details of the plugging are described in the Project Gasbuggy Site Restoration Final Report (DOE/NV, 1983). Drilling fluids and paraffin accumulated in tanks during well-plugging operations were buried on site at three locations (Landfills $\boldsymbol{A}, \boldsymbol{C}$, and D). Samples of this material registered less than the LLD for tritium (DOE/NV, 1983). The locations of the buried decontamination pad and the three burial sites for the drilling fluids are documented in the Project Gasbuggy Radiation Clearance Report (EIC, 1979) and shown in Figure 2-9. Both of the above reports state that no radiologicalcontaminated waste was buried on site.

Upon completion of all other restoration activities, soil samples were collected and radiological surveys were completed for the SGZ area (see Appendix A for discussion of results). The area was then reshaped, graded, and seeded (DOE/NV, 1983).

Remaining surface features include earthen berms, abandoned well markers, concrete pads, a pipe stanchion, and groundwater monitoring Well EPNG 10-36. 


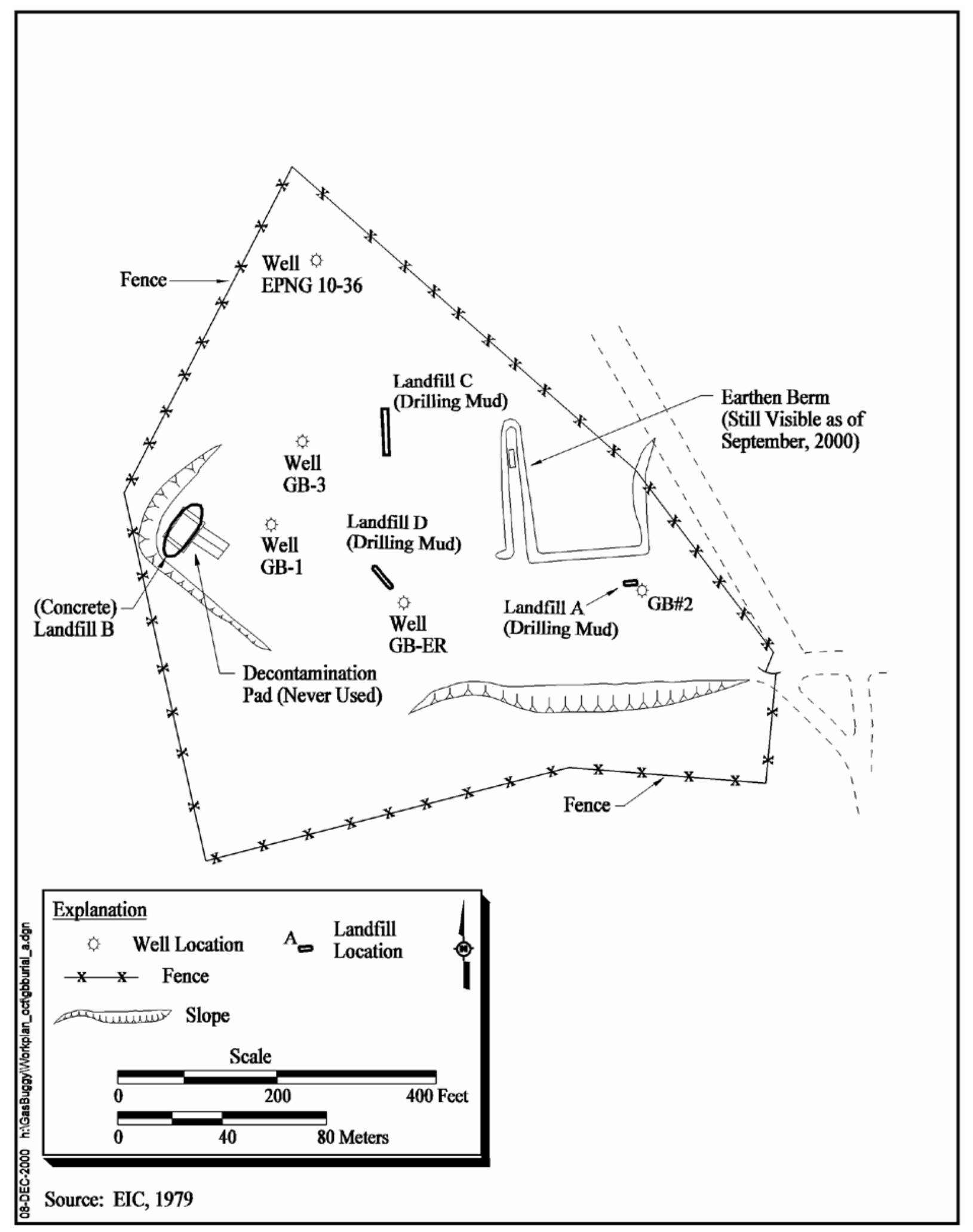

Figure 2-9

Surface Ground Zero Area Location of On-Site Burials 


\subsubsection{Well GB-D Area}

The Well GB-D area is located approximately 1,500 ft southeast of Well GB-E (Figure 2-5). This location included Well GB-D and associated facilities in an area approximately 2 to 3 acres in size. Well GB-D was used for the placement of instruments to measure ground motion during the Gasbuggy experiment. Possible sources of contamination at this location include a single mud pit and potential releases on the drill pad. Based on historical documentation, no postdetonation activities, such as drilling or gas production, were carried out at this location (AEC, 1971). Therefore, radiological contamination is not anticipated.

Well GB-D was plugged and abandoned during the 1978 restoration. Upon completion of all other restoration activities, the area around Well GB-D was reshaped, graded, and seeded (DOE/NV, 1983).

\subsubsection{Recording Trailer Park}

The RTP is located approximately 2,500 ft southwest of SGZ (Figure 2-1). The RTP consisted of several trailers, generators, and storage tanks set on a graded earthen pad of approximately 30,000 square feet $\left(\mathrm{ft}^{2}\right)$ (Figure 2-10 and Figure 2-11). Based on review of historical documentation, no septic systems or underground storage tanks (USTs) were installed at this location. Figure 2-10 shows a pit at the north end of the facility and denotes it as an "existing pit." This pit was likely in use during the Gasbuggy Project as a sump for the natural gas production well (Meridian Oil San Juan 28-4) located at the site and is not associated with AEC/DOE activities.

Structures were removed and the area graded and seeded prior to the 1978 restoration effort (DOE/NV, 1983).

\subsubsection{Control Point}

The CP is located approximately 2.5 miles southwest of the SGZ area (Figure 2-1). The CP consisted of approximately 20 to 25 temporary structures, generators, and storage tanks set on a graded earthen pad of approximately 2 acres (Figure 2-12). Additional facilities set up around the perimeter of the pad included back-up generators, various small structures, and a cleared area of approximately $4,200 \mathrm{ft}^{2}$ used as a weather balloon inflation area. Based on site drawings, a septic system consisting 
of a tank, influent lines, and approximately $150 \mathrm{ft}$ of clay leaching pipe was installed (Figure 2-13). The system serviced the operations coordination center trailer and a latrine trailer. Based on historical photographs (Wofford, 2000b), a mobile radiological laboratory was located at the southern end of the CP. Other possible sources of contamination at this site include fuel storage tanks and generator locations.

All structures were removed and the area graded and seeded prior to the 1978 restoration effort (DOE/NV, 1983).

\subsubsection{Helicopter Pad}

The helicopter pad is located approximately one-half mile southwest of the CP (Figure 2-1). No historical drawings of the HP could be located. However, based on Figure 2-1, the helicopter pad appears to consist of two compacted earthen pads set in a larger cleared area of approximately two acres. No documentation has been found indicating if fuel was stored at this location. Based on process knowledge from other underground test areas, fuel was stored above ground, typically in 55-gallon drums.

\subsection{Previous Investigations}

A summary of previous investigations is listed on Table 2-1. A summary and discussion of available radiological data for the site surface is provided in Appendix A. In addition, details on the preliminary field investigation conducted by DOE in August and September, 2000, and the results of that investigation are presented in Appendix C. 


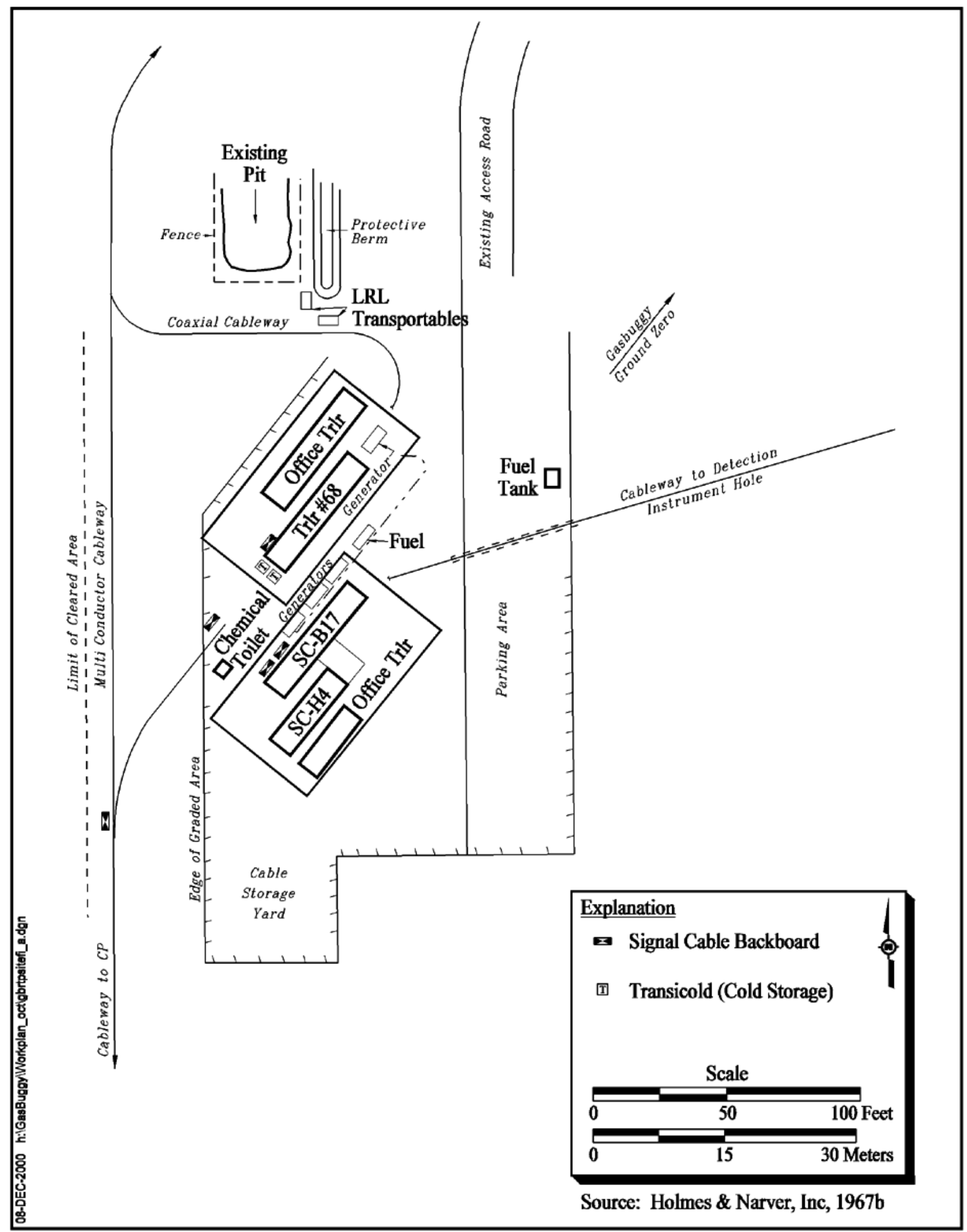

Figure 2-10

Recording Trailer Park Site Plan Gasbuggy, New Mexico 


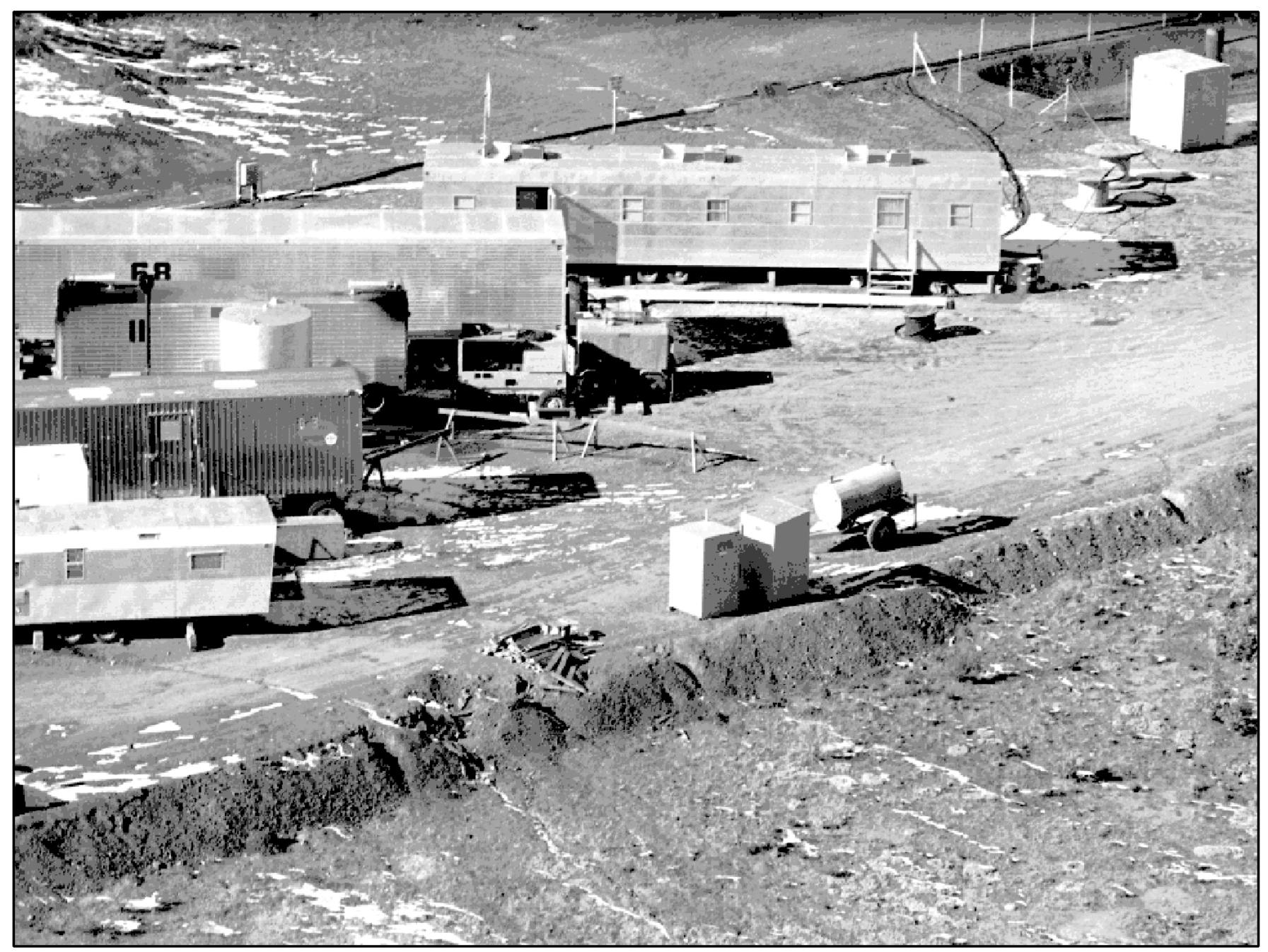

Figure 2-11

Oblique Photograph of the Recording Trailer Park 


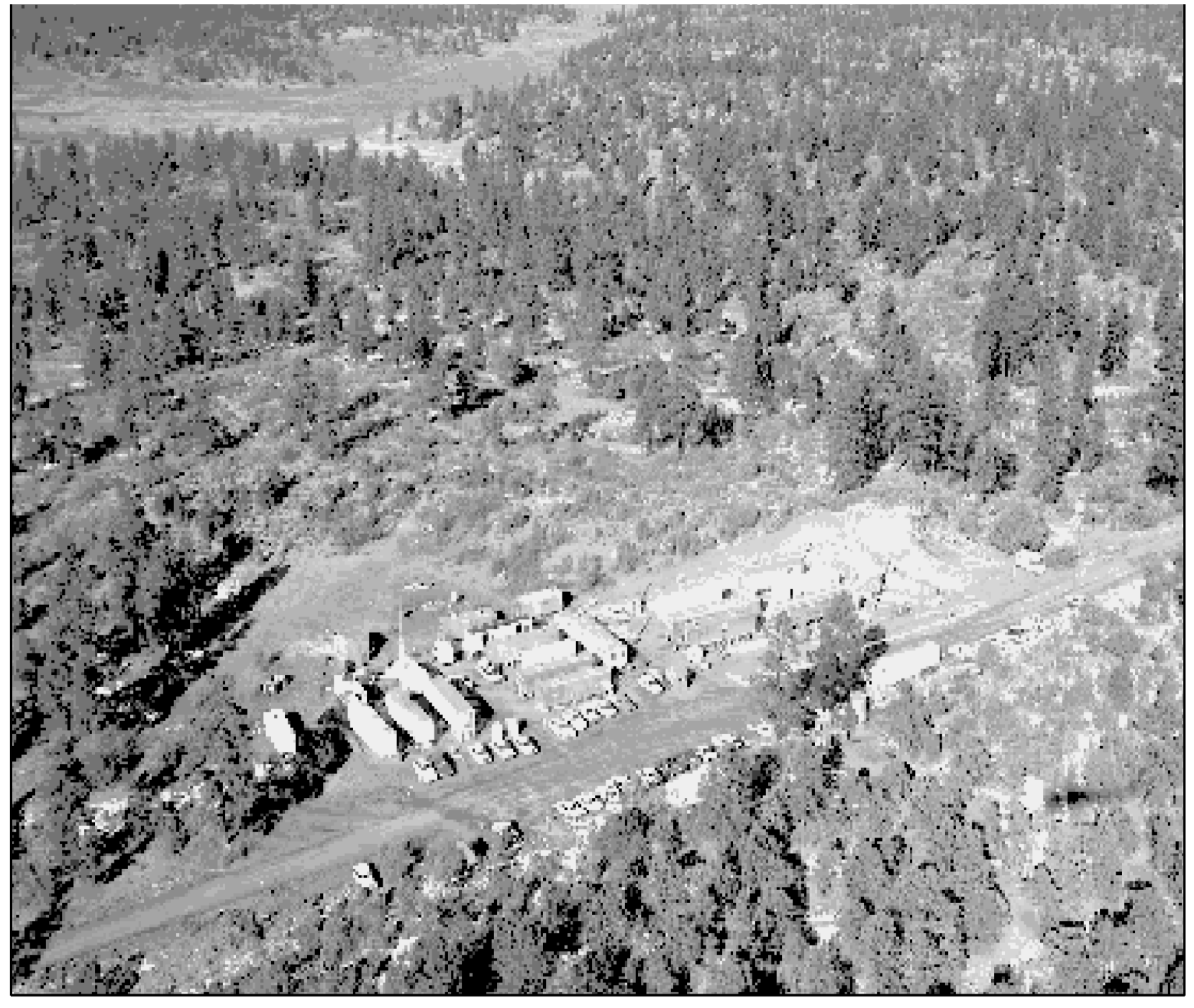

Figure 2-12 


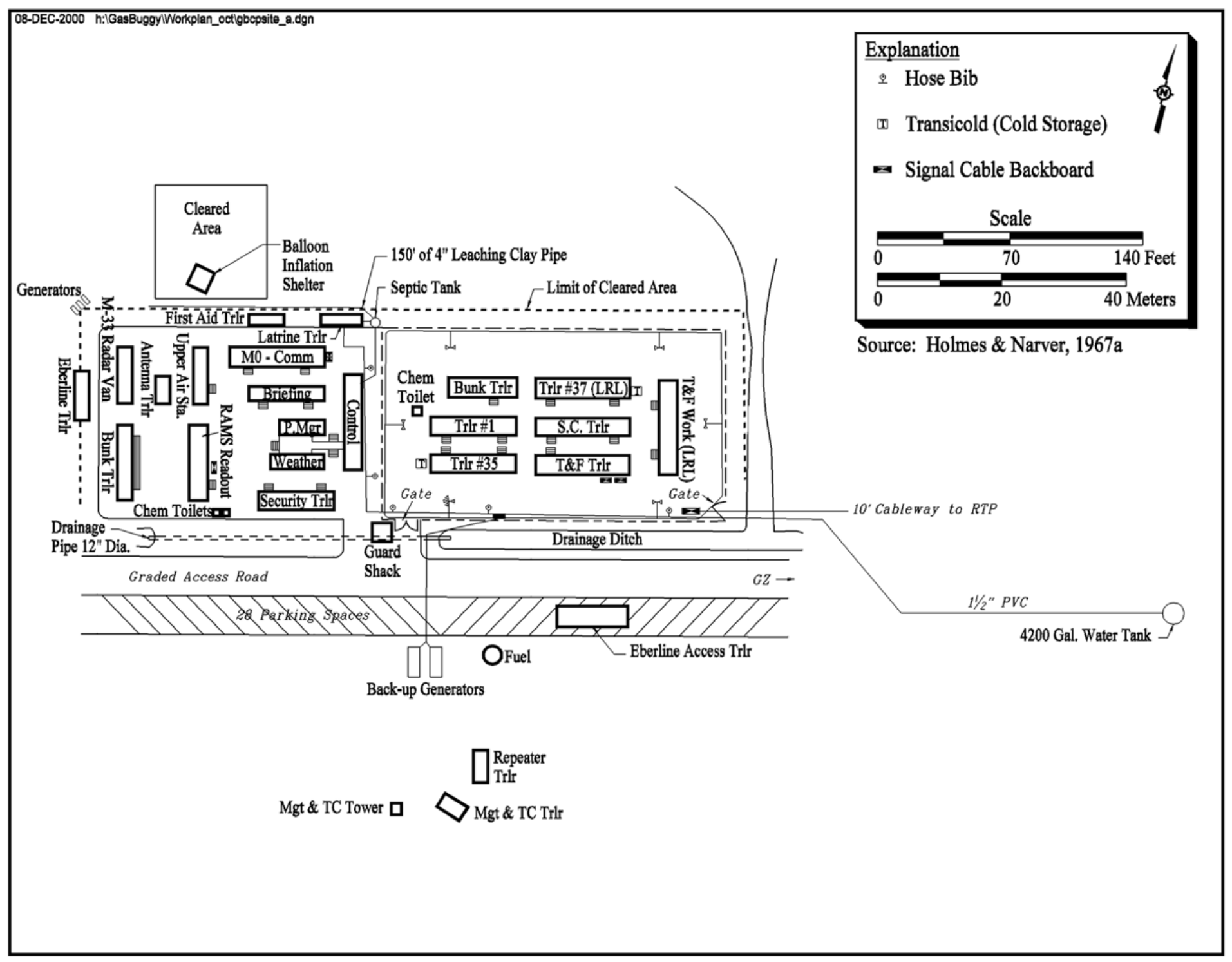

Figure 2-13

Control Point Site Plan Gasbuggy, New Mexico 
Table 2-1

Monitoring and Previous Investigations

(Page 1 of 2)

\begin{tabular}{|c|c|}
\hline Date & Description of Activity \\
\hline 1965 to 1968 & $\begin{array}{l}\text { A comprehensive characterization program for the subsurface geologic and hydrogeologic } \\
\text { attributes of the Gasbuggy Site was carried out for siting and planning the project. These } \\
\text { began with a feasibility study (EPNG et al., 1965) and pretest summary report (LRL, 1967a). } \\
\text { Detailed hydrogeologic data from site wells are documented by the U.S. Geological Survey } \\
\text { (Koopman et al., 1968a, 1968b; Weir, 1971) and summarized by Mercer (1967, 1969) in an } \\
\text { overall evaluation of site hydrology. Geologic conditions and physical data from cores } \\
\text { (e.g., porosity) were compiled by Lawrence Radiation Laboratory (LRL) (now Lawrence } \\
\text { Livermore National Laboratory [LLNL]) (1967a) in their assessment of the acceptability of } \\
\text { the site. }\end{array}$ \\
\hline 1968 to 1973 & $\begin{array}{l}\text { Evaluation of the test effectiveness in improving gas recovery from the Pictured Cliffs is the } \\
\text { focus of numerous posttest publications (Holzer, 1970; LRL, 1968a; LRL, 1970). The } \\
\text { chemical and radiochemical composition of the natural gas was reported by Smith and } \\
\text { Moymer (1969). A larger than expected inflow of water to the chimney was evaluated by } \\
\text { Power and Bowman (1970). Overall groundwater safety was examined by Sokol (1970). } \\
\text { An extensive bibliographic listing of both pretest and posttest reports can be found in the } \\
\text { Gasbuggy Site Restoration Final Report (DOE/NV, 1983). }\end{array}$ \\
\hline $\begin{array}{l}\text { August } 1967 \text { to June } \\
1968\end{array}$ & $\begin{array}{l}\text { The Southwestern Radiological Health Laboratory conducted off-site radiological safety } \\
\text { operations prior to, during, and after the detonation. Sampling and/or monitoring of milk, } \\
\text { water, air, and vegetation were conducted. No release of radioactivity was detected by } \\
\text { monitoring or in the analysis of samples collected following detonation (DHEW, 1970). }\end{array}$ \\
\hline December 10, 1967 & Gasbuggy detonation (AEC, 1971). \\
\hline $\begin{array}{l}\text { December } 10,1967 \text { to } \\
\text { January } 25,1968\end{array}$ & $\begin{array}{l}\text { Gasbuggy detonation, reentry, and initial production testing surveillance program } \\
\text { (AEC, 1971). See Appendix A. }\end{array}$ \\
\hline $\begin{array}{l}\text { June to July, } 1968 \text { and } \\
\text { November } 1968 \text { to } \\
\text { November } 1969\end{array}$ & Radiological surveillance for production testing (AEC, 1971; EIC, 1971). See Appendix A. \\
\hline $\begin{array}{l}\text { November } 5,1969 \text { to } \\
\text { November } 10,1970\end{array}$ & $\begin{array}{l}\text { Natural gas sampling. Production from } 28 \text { wells located within a five-mile radius of Project } \\
\text { Gasbuggy was resumed on October } 30 \text { and } 31,1969 \text {. Samples of gas were taken from } \\
\text { collection lines. Only naturally occurring Radon-222 was detected (EPA, 1973). }\end{array}$ \\
\hline 1972 to present & $\begin{array}{l}\text { The U.S. Environmental Protection Agency (EPA) conducts annual Long-Term Hydrological } \\
\text { Monitoring Program (LTHMP). Samples have been collected since } 1972 \text { from the EPNG } \\
\text { Well 10-36 and local supply wells, springs, and surface waters (DOE/NV, 1988). Well } \\
\text { EPNG } 10-36 \text { has yielded tritium activities between } 100 \text { and approximately } 550 \text { picocuries } \\
\text { per liter (pCi/L) in each year from } 1984 \text { to } 1998 \text { except for } 1987 \text { (EPA, 1989a and 1999b). } \\
\text { The sample collected in } 1999 \text { yielded a tritium activity of } 93+/-4.6 \text { pCi/L (EPA, 1999b). } \\
\text { Prior to 1984, tritium was below the laboratory detection limit. Results are published } \\
\text { annually in a series of reports (e.g., EPA, 1999b). The levels of tritium detected in the well } \\
\text { are less than } 5 \text { percent of the drinking water standard (i.e., } 2,000 \text { pCi/L) (CFR 1999b). } \\
\text { Sampling by EPA has also detected Cs-137 at concentrations up to } 16 \text { pCi/L in Well EPNG } \\
10-36 \text { between } 1990 \text { and } 1994 \text { (EPA, } 1992 \text {; DOE/NV, 1994a and } 1995 ; \text { Boehlecke, 2001). } \\
\text { This concentration is less than } 10 \text { percent of the drinking water standard (CFR 1999b). No } \\
\text { Cs-137 was detected in } 1992 \text { or since } 1994 \text {. }\end{array}$ \\
\hline
\end{tabular}


Table 2-1

Monitoring and Previous Investigations

(Page 2 of 2)

\begin{tabular}{|c|c|}
\hline Date & Description of Activity \\
\hline May to November, 1973 & $\begin{array}{l}\text { Radiological surveillance for } 1973 \text { production testing. All air and atmospheric moisture } \\
\text { samples collected during flaring operations were either below background levels or below } \\
\text { the applicable Concentration Guide levels (EPA, 1974). See Appendix A. }\end{array}$ \\
\hline $\begin{array}{l}\text { August to September, } \\
1978\end{array}$ & $\begin{array}{l}\text { During site restoration activities, radiological sampling/analysis and site surveys were } \\
\text { conducted including waste, soil, and vegetation sampling. A beta/gamma survey was also } \\
\text { conducted (DOE/NV, 1983). See Appendix A. }\end{array}$ \\
\hline 1986 & $\begin{array}{l}\text { Nine soil samples were collected from "operational" areas within the SGZ area and } \\
\text { analyzed by the Toxicity Characteristic Leaching Procedure for pesticides, herbicides, } \\
\text { metals, and volatile halocarbons. No hazardous substances were detected (REECo, 1986) }\end{array}$ \\
\hline April 1988 & $\begin{array}{l}\text { A Comprehensive Environmental Response Compensation, and Liability Act (CERCLA) } \\
\text { preliminary assessment was conducted to determine CERCLA hazard ranking. The Hazard } \\
\text { Ranking System score was not high enough to be registered on the National Priority List } \\
\text { (DOE/NV, 1988). }\end{array}$ \\
\hline June 1993 & $\begin{array}{l}\text { EPA surface gamma survey of Gasbuggy Site. Surveys taken at on-site locations in all } \\
\text { cases were similar to those taken at off-site locations (EPA, 1995). See Appendix A. }\end{array}$ \\
\hline June 1993 & $\begin{array}{l}\text { A Class III Cultural resources survey, a floodplains and wetlands survey, and a sensitive } \\
\text { species survey was conducted for the surface ground zero and surrounding area. The } \\
\text { potential for adverse impacts to sensitive species, wetlands, or cultural resources resulting } \\
\text { from the proposed investigation at the Gasbuggy Site was determined to be low } \\
\text { (DOE/NV 1993a; b; and d). }\end{array}$ \\
\hline October 27, 1994 & $\begin{array}{l}\text { EG\&G Energy Measurements performs an aerial radiological survey of Project Gasbuggy } \\
\text { and surrounding area. No significant man-made radioactivity was found (EG\&G EM, 1995). } \\
\text { See Appendix A. }\end{array}$ \\
\hline May 23, 1994 & $\begin{array}{l}\text { Production tubing from Well EPNG } 10-36 \text { pulled to allow casing integrity logging as } \\
\text { requested by the BLM (DRI, 1996b). }\end{array}$ \\
\hline $\begin{array}{l}\text { May } 27 \text { to May } 30,1994 \\
\text { and } \\
\text { May } 19 \text { to May 22, } 1995\end{array}$ & $\begin{array}{l}\text { The Desert Research Institute (DRI) conducts a detailed hydrologic logging and sampling } \\
\text { effort of Well EPNG 10-36. Results are used in DRI reports "Assessment of Hydrologic } \\
\text { Transport of Radionuclides from the Gasbuggy Underground Nuclear Test Site, New } \\
\text { Mexico" and "Tritium Migration at the Gasbuggy Site: Evaluation of Possible Hydrologic } \\
\text { Pathways" (DRI, 1996a and b). }\end{array}$ \\
\hline $\begin{array}{l}\text { September } 1994 \text { and } \\
\text { September } 1999\end{array}$ & $\begin{array}{l}\text { Casing integrity logging of Well EPNG } 10-36 \text { is completed (project files). These studies } \\
\text { have been inconclusive as to the integrity of the casing, and further evaluation will be part of } \\
\text { the subsurface investigation presented in Section } 5.0 \text {. }\end{array}$ \\
\hline $\begin{array}{l}\text { August to September, } \\
\qquad 2000\end{array}$ & $\begin{array}{l}\text { DOE conducts a preliminary site investigation including sensitive species surveys, cultural } \\
\text { resources surveys, surface geophysical surveys, and limited soil sampling and analysis. } \\
\text { Details and results are presented in Appendix C. }\end{array}$ \\
\hline
\end{tabular}




\subsection{Data Quality Objectives}

The DQO process is a strategic planning approach based on the scientific method that is used to prepare for a site characterization data collection activity (EPA, 1994a). Data quality objectives were used for the Gasbuggy Site Characterization Work Plan to develop an effective scientific and resource-efficient data collection design.

The DQOs for the investigation of the Gasbuggy Site are designed to ensure that data of sufficient quantity and quality are collected to establish current site conditions. These data will be used to identify and evaluate if further action is required to achieve long-term closure of the site that is protective of human health and the environment.

\subsection{Conceptual Site Model}

A site-specific conceptual site model (CSM) for the Gasbuggy Site is provided in Figure 3-1. This model is based on the assumption that current land use (recreational and grazing) will continue. The CSM illustrates the relationships between the identified potential sources of contamination, the mechanism for release and migration away from the potential source, the potential pathways the contamination would follow once released, the exposure routes that potential contamination would travel to affect receptors, and the potential receptors that would be impacted by the potential contamination.

The Gasbuggy Project consisted of five distinct operational areas: SGZ area, Well GB-D pad, RTP, $\mathrm{CP}$, and HP. Within each of these AOCs are potential surface/shallow subsurface sources of contamination such as the flare stack area and associated tritium contamination within the SGZ area, buried drilling mud pits, and/or landfills. Within the deep subsurface, the source of potential contamination is the Gasbuggy test cavity.

As required by the DQO process, a conceptual site model presumes that potential migration of contamination from these potential sources into the soil, groundwater (shallow and/or deep systems), and natural gas resources may occur. 


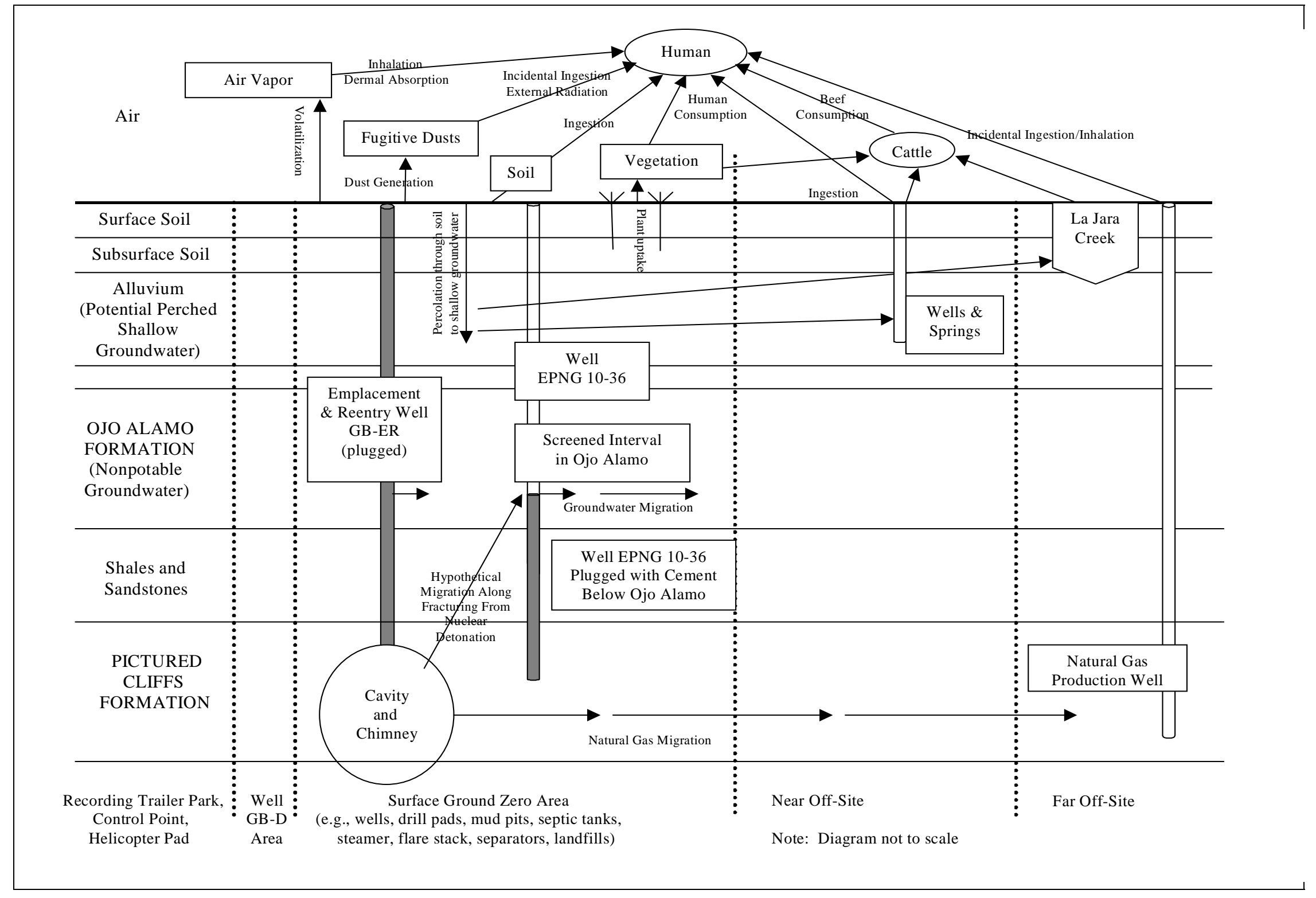

Figure 3-1

\section{Gasbuggy Conceptual Site Model}


The field investigation will be conducted to allow for either the modification or termination of characterization activities, when it is determined that sufficient data exists to support or refute the conceptual site model. If, during the planned field investigation, the conceptual model is proven to be incorrect (e.g., the extent of contamination is greater than predicted), a contingency would be implemented to adjust the scope of the field investigation. For example, this contingency may include the modification of the sampling strategies to include areas outside the original study limits to fully identify the extent of contamination.

\subsubsection{Surface Conceptual Site Model}

Potential migration of contamination in surface/shallow subsurface soils and shallow groundwater may have occurred. The release mechanisms that would facilitate migration include the following:

- Percolation of precipitation through impacted soil and transport of potential contamination into shallow subsurface soil or into the shallow groundwater

- Potential contaminated shallow groundwater migration

- Volatilization of volatile organic compounds (VOCs), semivolatile organic compounds (SVOCs), or tritium into the atmosphere

- Surface contaminants entering the atmosphere as fugitive dusts

- Uptake of contaminants by plants from surface/shallow subsurface soils

Potential exposure routes to humans or ecological receptors include ingestion, dermal contact, or inhalation. Pathways include the following, with the route specified:

- Contaminant uptake by plants or animals (ingestion)

- Contaminant migration to shallow groundwater or surface water (ingestion and dermal)

- Contaminants in surface soil (ingestion and dermal)

- Contaminants in fugitive dust (inhalation)

- Contaminant uptake by humans through beef and game animals (ingestion)

These identified potential sources and release mechanisms for potential contaminant migration will formulate the basis for the design of the characterization work plan. The data collected by this characterization program will be utilized to determine if there is contamination and, if so, determine if there is an adverse impact to potential receptors (e.g., human health and the environment) through the 
preparation of a risk assessment. The risk assessment, if required, will be conducted using the rancher and recreationalist scenarios as well as a Native American scenario using a modified recreationalist scenario. A corrective action alternative analysis will be completed should the risk assessment indicate there is an unacceptable risk to potential receptors. The DQO process for the site surface/shallow subsurface is summarized in Table 3-1.

\subsubsection{Subsurface Conceptual Site Model}

Potential migration of contamination from the nuclear cavity may have occurred. A site-specific conceptual model for the subsurface at the Gasbuggy Site is provided in Figure 3-1. The possible pathways for potential migration from the source include:

- Migration of natural gas in the Pictured Cliffs Formation

- Fractures or failed borehole seals connecting the cavity and the overlying Ojo Alamo aquifer

- Migration of groundwater in the Ojo Alamo aquifer

The closest water-bearing formation to the underground nuclear test is the overlying Ojo Alamo Sandstone, with its lower boundary approximately $600 \mathrm{ft}$ above the detonation point. It is the only aquifer that conceivably could be affected by the test, although it is actually beyond the fracture radius observed. Fracturing from the Gasbuggy test was predicted to extend out to a radius of $425 \mathrm{ft}$, consistent with observations of cable and casing breaks in Well GB-1 at a distance of $480 \mathrm{ft}$ and in Well GB-ER at $444 \mathrm{ft}$. A chimney height of $335 \mathrm{ft}$ above the detonation point was also observed. At these distances, fractures may extend from the Pictured Cliffs up into the overlying Fruitland Sandstone and Kirtland Shale, and downward into the Lewis Shale. The shales are considered aquitards due to extremely low transmissivity, and both the Pictured Cliffs and Fruitland formations are gas-bearing and not considered to contain mobile water at the site (LRL, 1967a).

Potential exposure routes include ingestion, dermal contact, or inhalation of contaminated groundwater or natural gas. The potential exposure route by ingestion of Ojo Alamo groundwater can be eliminated based on the very poor water quality. Sulfate in the Ojo Alamo at Well EPNG 10-36 is over 5,000 milligrams per liter (mg/L) (DRI, 1996b), whereas the standard for domestic supply in New Mexico is $600 \mathrm{mg} / \mathrm{L}$ (NMAC, 1996a). 
Table 3-1

\section{Summary of Gasbuggy Quality Objectives for Surface and Shallow Subsurface Investigation}

\begin{tabular}{|c|c|c|c|c|c|}
\hline $\begin{array}{c}\text { Step } 1 \\
\text { State the Problem }\end{array}$ & $\begin{array}{r}\text { Potential surface/shallow subsurf } \\
\text { location of potential sources ar } \\
\text { contar }\end{array}$ & $\begin{array}{l}\text { ice contamination at the Gast } \\
\text { Id the nature and extent of po } \\
\text { nination at the site poses a th }\end{array}$ & $\begin{array}{l}\text { buggy Site may pose a th } \\
\text { otential contamination is } u \\
\text { rreat to human health and }\end{array}$ & $\begin{array}{l}\text { eat to human health and } \\
\text { known. Therefore, it is } \\
\text { or the environment. }\end{array}$ & $\begin{array}{l}\text { e environment. The } \\
\text { known if potential }\end{array}$ \\
\hline $\begin{array}{c}\text { Step } 2 \\
\text { Identify the Decision }\end{array}$ & $\begin{array}{l}\text { Step } 3 \\
\text { Identify the Inputs to the } \\
\text { Decision }\end{array}$ & $\begin{array}{l}\text { Step } 4 \\
\text { Define the Study } \\
\text { Boundaries }\end{array}$ & $\begin{array}{c}\text { Step } 5 \\
\text { Develop a Decision } \\
\text { Rule }\end{array}$ & $\begin{array}{c}\text { Step } 6 \\
\text { Specify Limits on } \\
\text { Decision Errors }\end{array}$ & $\begin{array}{c}\text { Step } 7 \\
\text { Optimize the } \\
\text { Design for } \\
\text { Obtaining Data }\end{array}$ \\
\hline $\begin{array}{l}\text { Determine the radiological and } \\
\text { chemical COPCs }\end{array}$ & $\begin{array}{l}\text { Historical data and } \\
\text { documentation and preliminary } \\
\text { field investigation }\end{array}$ & \multirow{8}{*}{$\begin{array}{c}\text { Areas of Operation: } \\
\text { Surface Ground Zero Area } \\
\text { Well GB-D Area } \\
\text { Recording Trailer Park } \\
\text { Control Point } \\
\text { Helicopter Pad } \\
\text { AOCs: } \\
\text { Mud pits, landfills, } \\
\text { operational areas, storage } \\
\text { areas, storage areas, } \\
\text { potential release sites, and } \\
\text { septic tanks }\end{array}$} & \multirow{8}{*}{$\begin{array}{c}\text { Area-specific. } \\
\text { If no COPCs exceed } \\
\text { PALs, then no action is } \\
\text { required. } \\
\text { If COPCs exceed } \\
\text { PALs, then a risk } \\
\text { assessment will be } \\
\text { conducted. } \\
\text { If risk assessment } \\
\text { determines } \\
\text { unacceptable levels, } \\
\text { then a corrective action } \\
\text { alternatives analysis } \\
\text { will be conducted. }\end{array}$} & \multirow{8}{*}{$\begin{array}{l}\text { Decision errors are } \\
\text { based on risk } \\
\text { assessment. } \\
\text { If data is insufficient to } \\
\text { make a decision, then } \\
\text { additional data will be } \\
\text { collected. }\end{array}$} & \multirow{8}{*}{$\begin{array}{l}\text { Develop work plan } \\
\text { and technical } \\
\text { approach. }\end{array}$} \\
\hline $\begin{array}{l}\text { Determine Preliminary Action } \\
\text { Levels (PAL) for COPCs }\end{array}$ & $\begin{array}{c}\text { State and Federal Regulations, } \\
\text { technological limits, site-specific } \\
\text { dose-based levels }\end{array}$ & & & & \\
\hline $\begin{array}{l}\text { Determine the locations of the } \\
\text { sources of potential } \\
\text { contamination }\end{array}$ & $\begin{array}{c}\text { Historical data and } \\
\text { documentation, geophysical } \\
\text { techniques, and field } \\
\text { observations }\end{array}$ & & & & \\
\hline $\begin{array}{c}\text { Determine if COPC } \\
\text { concentrations exceed PALs }\end{array}$ & $\begin{array}{c}\text { Results of field-screening and/or } \\
\text { laboratory data, statistical } \\
\text { analysis of data, background } \\
\text { conditions }\end{array}$ & & & & \\
\hline $\begin{array}{l}\text { Determine if pathway to shallow } \\
\text { groundwater exists }\end{array}$ & $\begin{array}{l}\text { Depth of soil contamination, } \\
\text { depth to shallow groundwater, } \\
\text { soil properties, analytical results }\end{array}$ & & & & \\
\hline $\begin{array}{l}\text { Determine the nature and extent } \\
\text { of potential contamination (soil } \\
\text { and shallow groundwater) }\end{array}$ & $\begin{array}{l}\text { Results of field-screening and/or } \\
\text { laboratory data, soil properties, } \\
\text { mobility of COPCs }\end{array}$ & & & & \\
\hline $\begin{array}{l}\text { Determine if COPC } \\
\text { concentrations are within } \\
\text { acceptable risk levels }\end{array}$ & $\begin{array}{l}\text { Risk requirements, future land } \\
\text { use scenarios, risk levels, dose } \\
\text { calculations for tritium }\end{array}$ & & & & \\
\hline $\begin{array}{c}\text { Determine if a corrective action is } \\
\text { necessary }\end{array}$ & $\begin{array}{l}\text { Results of risk assessment, dose } \\
\text { calculations for tritium }\end{array}$ & & & & \\
\hline
\end{tabular}


The identified source and release mechanisms for potential contaminant migration formulated the basis for the design of the characterization work plan. Currently, there is no technology to remediate underground nuclear test cavities; therefore, the approach is to minimize potential exposure by using existing data and analysis of sufficient quantity and quality to evaluate if existing subsurface intrusion restrictions need to be adjusted to be protective of human health and the environment.

Additional information on the subsurface model and how it relates to the subsurface work plan is presented in Section 5.0. The DQO process for the site surface/shallow subsurface is summarized in Table 3-2.

\subsection{Contaminants of Potential Concern}

The COPCs for the surface/shallow subsurface and deep subsurface investigations were determined based on an evaluation of site-specific historical documentation regarding the drilling fluids, drilling methods, site operations, previous sampling efforts performed at Gasbuggy, process knowledge from other underground nuclear test areas, and State of New Mexico regulatory guidance.

\subsubsection{COPCs for Surface and Shallow Subsurface Investigation}

To determine if contamination exists, results of laboratory analysis for chemical COPCs in soil will be compared to preliminary action levels (PALs). For the purposes of this investigation, the PALs will be the industrial risk-based preliminary remediation goals (PRGs) provided in the EPA Region IX Risk-Based Concentration Table (EPA, 1999c). Laboratory results above PALs indicate the presence of COPCs at levels that may require a risk assessment to determine if corrective actions are required. Comparisons will also be made to representative background conditions established through statistical analysis of sample results. If representative inorganic site characterization values from AOCs are shown through statistical analysis to be not significantly different from representative background values, then a risk assessment may not be warranted. If representative inorganic background values exceed the EPA Region IX PRGs, risk due solely to background values may be estimated independently for comparison to the risk posed by the actual detected or representative COPC concentrations; however, the risk due solely to background constituent concentrations should not trigger corrective action (NMED, 2000a). 
Table 3-2

\section{Summary of Gasbuggy Quality Objectives for Subsurface Investigation}

\begin{tabular}{|c|c|c|c|c|c|}
\hline $\begin{array}{c}\text { Step } 1 \\
\text { State the Problem }\end{array}$ & $\begin{array}{l}\text { Significant radionuclide contamination } \\
\text { existing subsurface intrusion restriction } \\
\text { resources of value, under existing cond } \\
\text { health or the environment if it occurrec }\end{array}$ & $\begin{array}{l}\text { emains in the Gasbugg } \\
\text { are sufficient to elimin } \\
\text { tions or during future re }\end{array}$ & $\begin{array}{l}\text { avity and can not be } \\
\text { potential exposure } \\
\text { urce development, } r\end{array}$ & $\begin{array}{l}\text { emediated by existing } \\
\text { athways, or prevent co } \\
\text { whether such transpor }\end{array}$ & $\begin{array}{l}\text { hnology. It is not known if } \\
\text { Iminant transport into } \\
\text { lould pose a risk to human }\end{array}$ \\
\hline $\begin{array}{c}\text { Step } 2 \\
\text { Identify the Decision }\end{array}$ & $\begin{array}{l}\text { Step } 3 \\
\text { Identify the Inputs to the } \\
\text { Decision }\end{array}$ & $\begin{array}{c}\text { Step } 4 \\
\text { Define the Study } \\
\text { Boundaries }\end{array}$ & $\begin{array}{c}\text { Step } 5 \\
\text { Develop a } \\
\text { Decision Rule }\end{array}$ & $\begin{array}{l}\text { Step } 6 \\
\text { Specify Limits on } \\
\text { Decision Errors }\end{array}$ & $\begin{array}{c}\text { Step } 7 \\
\text { Optimize the Design } \\
\text { for Obtaining Data }\end{array}$ \\
\hline $\begin{array}{c}\text { Determine the radiological and } \\
\text { chemical COPCs. }\end{array}$ & $\begin{array}{l}\text { Historical data, process knowledge, } \\
\text { known radiological decay rates }\end{array}$ & \multirow{8}{*}{$\begin{array}{l}\text { Modeling boundary to } \\
\text { be based on scoping } \\
\text { calculations. }\end{array}$} & \multirow{8}{*}{$\begin{array}{l}\text { If calculations } \\
\text { predict possible } \\
\text { contaminant } \\
\text { transport beyond } \\
\text { existing } \\
\text { restrictions, either } \\
\text { reduce } \\
\text { uncertainty with } \\
\text { additional data } \\
\text { collection, or } \\
\text { extend } \\
\text { institutional } \\
\text { controls if } \\
\text { indicated by risk } \\
\text { assessment. }\end{array}$} & \multirow{8}{*}{$\begin{array}{l}\text { Decision errors are } \\
\text { based on model. } \\
\text { If data is insufficient to } \\
\text { make a decision, then } \\
\text { additional data will be } \\
\text { collected. }\end{array}$} & \multirow{8}{*}{$\begin{array}{l}\text { Develop work plan and } \\
\text { technical approach. }\end{array}$} \\
\hline Determine the PALs for COPCs. & $\begin{array}{l}\text { State and federal regulations, site- } \\
\text { specific dose-based levels }\end{array}$ & & & & \\
\hline $\begin{array}{c}\text { Determine if the Ojo Alamo Aquifer is } \\
\text { a transport pathway for COPCs. }\end{array}$ & $\begin{array}{l}\text { Multiphase numerical modeling, } \\
\text { investigations in Well EPNG 10-36, } \\
\text { and future resource-use scenarios }\end{array}$ & & & & \\
\hline $\begin{array}{c}\text { Determine the nature and extent of } \\
\text { contamination in subsurface } \\
\text { resources. }\end{array}$ & $\begin{array}{c}\text { Historical data, knowledge of } \\
\text { subsurface geology and hydrology, } \\
\text { mobility of COPCs, multiphase } \\
\text { numerical modeling }\end{array}$ & & & & \\
\hline $\begin{array}{l}\text { Determine if future resource } \\
\text { development could impact the extent } \\
\text { of subsurface contamination. }\end{array}$ & $\begin{array}{l}\text { Multiphase numerical modeling and } \\
\text { future resource-use scenarios }\end{array}$ & & & & \\
\hline $\begin{array}{l}\text { Determine if COPC concentrations at } \\
\text { possible resource-use points are } \\
\text { within acceptable limits or whether a } \\
\text { human health dose assessment is } \\
\text { warranted. }\end{array}$ & $\begin{array}{l}\text { Multiphase numerical modeling, } \\
\text { future resource-use scenarios, } \\
\text { radionuclide concentration guidelines }\end{array}$ & & & & \\
\hline $\begin{array}{l}\text { Determine if existing subsurface } \\
\text { intrusion restrictions are adequate for } \\
\text { site closure. }\end{array}$ & $\begin{array}{l}\text { Modeling results, dose assessment } \\
\text { results, and future resource-use } \\
\text { scenarios }\end{array}$ & & & & \\
\hline $\begin{array}{l}\text { Determine if a long-term monitoring } \\
\text { program is technically warranted. }\end{array}$ & $\begin{array}{l}\text { Modeling results, subsurface } \\
\text { intrusion restrictions }\end{array}$ & & & & \\
\hline
\end{tabular}


As specified in the New Mexico Environment Department (NMED), Hazardous Waste Bureau Position Paper's “Use of Total Petroleum Hydrocarbon (TPH) Test Results for Site

Characterization," in the absence of other contaminants above risk-based cleanup levels, results for TPH may be used to guide potential cleanup (NMED, 2000b).

The NM QAPP's (Appendix B) “Laboratory Chemical, Toxicity Characteristic Leaching Procedure (TCLP), and Radiochemistry Analytical Requirements for New Mexico Sites" table allows for both Method 5035 and Method 8260B for VOC analysis. During the preliminary field investigation at the Gasbuggy Site (Appendix C), Method 8260B was used. Due to the remoteness of the site, planned work schedules, and required hold times for Method 5035, it is likely that, if Method 5035 were used, a significant portion of data would be qualified as estimated. Since estimated data would not be usable for risk assessment purposes (Wycoff, 2000), Method 8260B will be used during future investigations.

All laboratory data for chemical COPCs will be evaluated for data quality according to "Contract Laboratory Program National Functional Guidelines for Inorganic Data Review” (EPA, 1994b), or "Contract Laboratory Program National Functional Guidelines for Organic Data Review" (EPA, 1999d), as appropriate. In addition, five percent of this data will be subjected to independent verification using the same guidelines. All laboratory data for radiochemistry analysis will be evaluated according to internal procedures.

The COPCs to be considered were determined based on an evaluation of site-specific historical documentation, previous sampling efforts performed at the Gasbuggy Site, and process knowledge from other underground nuclear test areas.

A review of historical documentation found no indication of releases of potentially hazardous chemical constituents at the Gasbuggy Site other than those contained in drilling mud. Based on knowledge of drilling methods and the results of previous characterizations of mud pits associated with underground nuclear detonation sites, the mud pits at the Gasbuggy Site may contain diesel. Other COPCs associated with the drilling mud include metals such as chromium and possibly lead. The Project Gasbuggy Radiation Contamination Clearance Report (EIC, 1979) indicates that the decontamination pit constructed in 1967 had never been used and that solvents were not used during 
the 1978 restoration. Information on the locations of on-site laboratories and COPCs used in those laboratories is inconclusive.

Based on site history and historical analytical data, radionuclides other than tritium can be eliminated from consideration as COPCs for the surface/shallow subsurface investigation (see Appendix A). Results of tritium analysis of soil samples collected during the preliminary field investigation in August and September of 2000 (Appendix C) were used to evaluate if there is a potential for human health risks associated with tritium at the Gasbuggy Site. Based on the evaluation (see Appendix D), it was determined that the levels of tritium that exist at the site today do not pose a current or future risk. Therefore, further characterization of the site for tritium contamination is not necessary.

The following is a comprehensive list of site characterization COPCs for future surface/shallow subsurface investigations (additional COPCs may be analyzed for waste characterization purposes):

- TPH, diesel and gasoline range

- VOCs

- SVOCs

- Total Resource Conservation and Recovery Act (RCRA) Metals

Based on discussions with the New Mexico Oil Conservation Division (NM OCD), COPCs listed in the New Mexico Water Quality Control Commission (NM WQCC) regulations in Title 20, New Mexico Administrative Code (NMAC) 6.2.3103, "Standards for Ground Water of 10,000 milligrams per liter Total Dissolved Solids Concentration or Less" (NMAC, 1996a), need to be considered to ensure that waste in the mud pits will be managed "in a manner to prevent contamination to surface or subsurface waters," as stated in 19 NMAC 15.C.105 (NMAC, 1996b).

The following additional parameters listed in 20 NMAC 6.2.3103 were analyzed for during the preliminary site investigation:

- Target Analyte List (TAL) metals plus boron, molybdenum, and uranium

- Major anions (i.e., bromide, chloride, cyanide, fluoride)

- Nitrates

- Sulfates

- Radium-226/-228 
Although listed in 20 NMAC 6.2.3103, Polychlorinated Biphenyls (PCBs) were not analyzed for based on site knowledge and sampling results from other underground test areas that indicate there is no reason to believe there is PCB contamination at this site.

All site characterization samples collected during the preliminary field investigation were soil samples (groundwater was not encountered) and, therefore, cannot be directly compared to the NM WQCC water quality standards. The soil sample results will be used, as necessary, to formulate corrective action decisions and/or as part of a risk assessment, if necessary. Additional sampling for these parameters is not planned unless conditions encountered in the field dictate and/or shallow groundwater sampling is required (see Section 4.3). If groundwater samples are collected for these parameters, the PALs will be the levels indicated in 20 NMAC 6.2.3103 (NMAC, 1996a).

\subsubsection{COPCs for Subsurface Investigation}

Radionuclides associated with underground nuclear explosions result from: (1) residual nuclear material that has not undergone a fission or thermonuclear reaction; (2) direct products of nuclear reactions (fission products and tritium); and (3) activation products induced by neutron capture in the immediate vicinity of the explosion (LLNL, 1976). A list of radionuclides that may be important for investigation of groundwater transport from underground tests is provided by LLNL (1995). The majority of radionuclides in the subsurface are nonvolatile or even refractory, therefore are unavailable for gas-phase transport. The only radionuclides detected in gas produced from the Gasbuggy cavity are Tritium, Carbon-14 (C-14), Argon-37 (Ar-37), Argon-39 (Ar-39), Krypton-85 (Kr-85), and Xenon-133 (Xe-133) (Holzer, 1970). Two of these have such short half-lives that they have essentially decayed away in the time since the test and are no longer of concern (Xe-133 and Ar-37). The significant COPCs for gas migration include:

- Tritium

- $\mathrm{Kr}-85$

- $\mathrm{C}-14$

- Ar-39

Tritium and $\mathrm{Kr}-85$ are responsible for essentially all of the radioactivity observed in the gas. About $350 \pm 20$ curies of $\mathrm{Kr}-85$ and about $4.5 \times 10^{4}$ curies of tritium are estimated to have been initially deposited in the chimney as a result of the Gasbuggy detonation (Holzer, 1970). As krypton is not 
retained to any significant extent by the body, tritium is the principal radionuclide of concern in the natural gas.

As will be discussed in Section 5.0, the pressure relationship between the Ojo Alamo and Pictured Cliffs precludes liquid-phase migration from the cavity up to the Ojo Alamo. Gas-phase transport is conceivable if there was a connection between the two formations shortly after the test, when the cavity was experiencing the high pressures of the detonation. The significant COPCs for groundwater migration are those that could have traveled to the Ojo Alamo in the gas phase, including some that subsequently decay to nonvolatile daughters. These include:

- Tritium

- $\mathrm{Kr}-85$

- $\mathrm{C}-14$

- Strontium-90 (Sr-90)

- Cesium-137 (Cs-137)

Annual monitoring of Well EPNG 10-36 by the EPA under the Long-Term Hydrological Monitoring Program (LTHMP) has detected tritium in the well above background in each year since 1984, except for 1987 (EPA, 1999b). The levels of tritium detected in the well are less than 5 percent of the drinking water standard (CFR 1999b). Sampling by EPA has also detected Cs-137 at concentrations up to 16 pCi/L in Well EPNG 10-36 between 1990 and 1994, although, no Cs-137 was detected in 1992, or since 1994 (EPA, 1992; DOE/NV 1994a and 1995; Boehlecke, 2001). These concentrations are less then 10 percent of the drinking water standard (CFR 1999b).

No chemical COPCs have been identified for the subsurface at Gasbuggy. The emplacement occurred through a 28 -inch (in.) borehole drilled to 4,350 ft, with a 20 -in. casing to the bottom of the borehole and cemented to land surface. A second 7-in. casing was installed to the device depth, with the annular space and casing itself filled with zones of cement and zones of sand (DOE/NV, 1978). This was a simple stemming program to contain the nuclear test underground. This process did not involve the use of large amounts of metals, such as lead, typically associated with other underground nuclear tests. 


\subsection{Surface and Shallow Subsurface Work Plan}

Additional field investigation will build on the data already acquired through historical research and the preliminary field investigation (Appendix C). The goal of further field investigation will be to fill existing data gaps in order to establish current site conditions and confirm or refute the CSM. Data collected will be used to identify and evaluate if further action is required to achieve permanent closure of the site that is protective of human health and the environment.

Additional investigation for the surface/shallow subsurface will consist of: (1) collecting additional surface/shallow subsurface soil samples to define the nature and extent of potential contamination in each AOC; (2) determining if there is or is not a path for COPCs to migrate to shallow groundwater; and (3) determine the nature and extent of potential contamination in the shallow groundwater, if applicable. Background conditions will be established by collecting soil samples and shallow groundwater samples, if applicable, at nonimpacted areas near the site. Figure 4-1 is a DQO decision flow chart that summarizes the characterization scope of work and technical approach for the additional field work proposed for the surface/shallow subsurface investigation.

The following sections define the technical approach and detail the activities to be completed for the additional field investigation. Unexpected site conditions may require modifications to the CSM, the DQOs, and/or field investigation activities.

\subsection{Demarcate Areas of Concern}

Historical aerial and oblique photographs, along with site engineering and "as-built" drawings, will be compared to the results of the geophysical surveys and the physical landmarks at the Gasbuggy Site to demarcate the AOCs. Locations for the AOCs will be found using landmarks and global positioning system (GPS) coordinates. The results of the preliminary field investigation including GPS coordinates will also aid in demarcating AOCs. Prior to beginning further soil investigation, the estimated extent of each AOC (e.g., mud pit, landfill, geophysical anomaly) will be located and staked. 


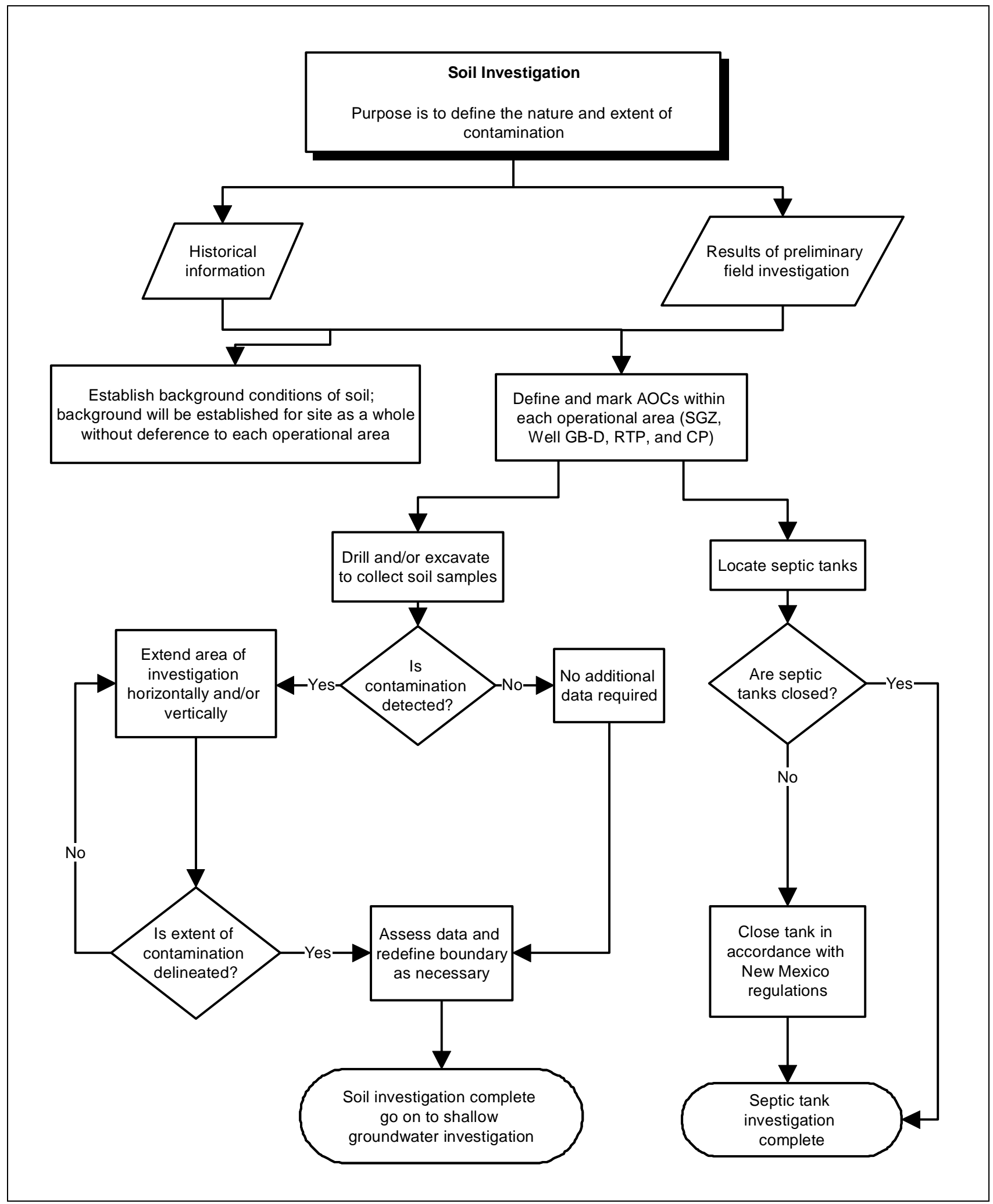

Figure 4-1

Surface and Shallow Subsurface DQO Decision Flow Chart

(Page 1 of 2) 


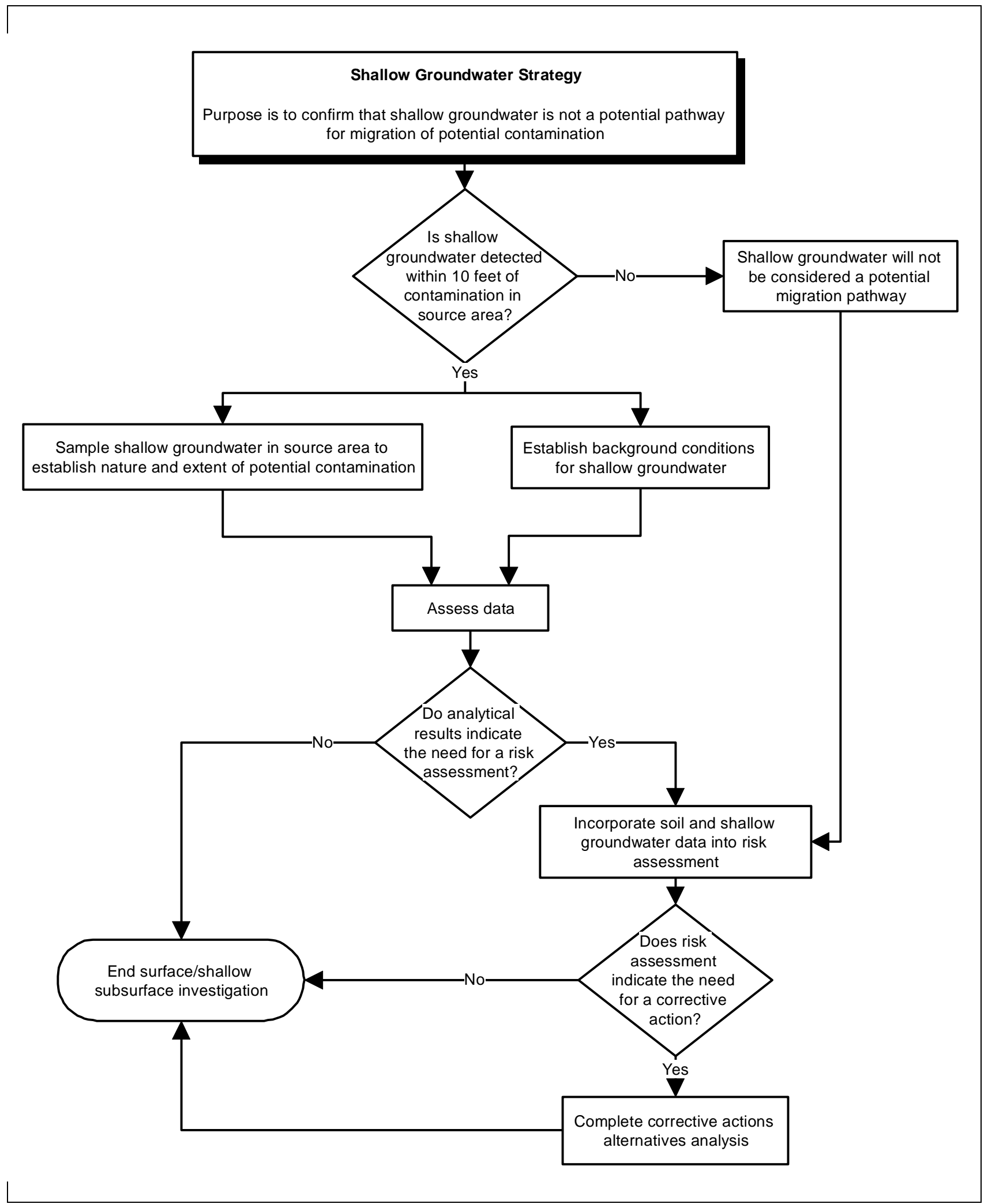

Figure 4-1

Surface and Shallow Subsurface DQO Decision Flow Chart (Page 2 of 2) 


\subsection{Soil Sampling Investigation}

Initial soil sampling will be conducted at the Well GB-D area, the RTP, and the CP operational areas. Follow-on soil sampling will be conducted at the SGZ area to fill data gaps that remain after the preliminary field investigation. No soil sampling is proposed for the HP operational area. Soil sampling will be conducted for the purpose of site characterization, quality control (QC), and waste characterization. Soil sampling will use a combination of biased sampling and systematic random sampling strategies. Biased samples will be collected in locations of known or suspected contamination. A systematic random sampling strategy will be utilized to characterize potential contamination in the mud pits.

Soil sampling will be conducted primarily by using drilling or direct-push technologies. Excavation may also be employed to collect soil samples at locations where geophysical surveys were unable to identify the exact location of a shallow subsurface feature.

\subsubsection{Representative Inorganic Background Sample Collection}

Background inorganic chemical concentrations for total RCRA metals will be established for the Gasbuggy Site. Systematic random sampling will be conducted in designated areas to collect samples for offsite laboratory analysis. The results will be used in comparing characterization samples and supporting risk assessments, if required.

Statistical methods have been employed in order to determine the appropriate number of samples to establish background concentrations for arsenic, barium, cadmium, chromium, lead, mercury, selenium, and silver. Equation 8 of Chapter 9 of SW-846 (EPA, 1996) gives the number of samples required to determine to within a specified percent error $\left(\mathrm{e}_{\mathrm{r}}\right)$ the mean concentration of a parameter normally distributed in the study area, with a variability measured by a relative standard deviation (coefficient of variation (CV)), at a confidence level of 90 percent as:

$$
\mathrm{n}=\left(\mathrm{t}_{0.90, \mathrm{n}-1} *\left[\mathrm{CV} / \mathrm{e}_{\mathrm{r}}\right]\right)^{2}
$$

where " $\mathrm{t}$ " is the one-tailed 90 percent Student's " $\mathrm{t}$ " value for the appropriate number of degrees of freedom (n-1). 
The $\mathrm{CV}$ in the above equation refers to the variability of the specific parameter in the medium being sampled. It is usually unavailable until sufficient samples from the site have been analyzed. The variability of the proposed analytical method is usually substituted as a first approximation.

However, in this case, data from five preliminary background soil samples taken at the Gasbuggy Site can be used to calculate the CV for the RCRA metals (Table 4-1). These samples were collected at depths ranging from 2 to $14 \mathrm{ft}$ bgs in two boreholes located near the SGZ area but outside of the AOCs. Statistical analysis confirms these data are normally distributed.

Table 4-1

Statistical Analysis of RCRA Metal Results for Preliminary Background Soil Samples

\begin{tabular}{|c|c|c|c|}
\hline Metal & $\begin{array}{c}\text { Mean Background } \\
\text { Concentration } \\
\mathbf{( m g / k g )}\end{array}$ & $\begin{array}{c}\text { Standard Deviation } \\
\text { (mg/kg) }\end{array}$ & $\begin{array}{c}\text { Relative Standard } \\
\text { Deviation } \\
\text { (percent) }\end{array}$ \\
\hline Arsenic & 2.12 & 0.719 & 33.9 \\
\hline Barium & 274.0 & 28.81 & 10.51 \\
\hline Cadmium & ND & NA & NA \\
\hline Chromium & 12.34 & 2.044 & 16.56 \\
\hline Lead & 8.44 & 2.14 & 25.3 \\
\hline Mercury & ND & NA & NA \\
\hline Selenium & ND & NA & NA \\
\hline Silver & ND & NA & NA \\
\hline
\end{tabular}

$\mathrm{mg} / \mathrm{kg}=$ Milligrams per kilogram

$\mathrm{ND}=$ Not detected

NA $=$ Not applicable

By rearranging the above equation and substituting the number of samples analyzed $(n=5)$, the one-sided Student's value for 4 degrees freedom at a 90 percent confidence level (1.533), and the relative standard deviations for each parameter, the percent error in the means of each analyte and the upper 90 percent confidence interval can be calculated as indicated in Table 4-2. Region IX PRGs (EPA, 1999c) are included for comparison.

A relative error of plus or minus 10 to 20 percent from the true mean at a confidence limit of 90 percent is considered acceptable for planned removal and remedial response studies (EPA, 1989b). 
Table 4-2 Calculation of Percent Error and 90 Percent Confidence Interval of RCRA Metal
Results for Preliminary Background Soil Samples

\begin{tabular}{|c|c|c|c|}
\hline Metal & $\begin{array}{c}\text { Mean Background } \\
\text { Concentration } \\
(\mathbf{m g} / \mathbf{k g})\end{array}$ & $\begin{array}{c}\text { PRG } \\
(\mathbf{m g} / \mathbf{k g})\end{array}$ & Percent Error \\
\hline \hline Arsenic & 2.12 & 2.7 & 23.3 \\
\hline Barium & 274 & 10,000 & 7.2 \\
\hline Chromium & 12.34 & 450 & 11.4 \\
\hline Lead & 8.44 & 100 & 17.4 \\
\hline
\end{tabular}

$\mathrm{mg} / \mathrm{kg}=$ Milligrams per kilogram

$P R G=$ Preliminary remediation goal for EPA Region IX (EPA, 1999c)

Thus, the number of samples already analyzed serves to adequately establish the background levels of barium, chromium, and lead at the Gasbuggy Site.

In order to more accurately determine the background level of arsenic, it will be necessary to analyze a total of at least ten samples (or five additional samples) in order to have the average arsenic concentration calculated from these 10 samples fall within the tolerable error of $+/-20$ percent with 90 percent confidence. These samples will be submitted for off-site analysis for all eight RCRA metals.

The five samples will be taken from preselected 4-ft intervals in soil borings. The borings will be located in an area that is undisturbed and unaffected by site operations. The depth of sample collection will be from depths between 4 and $12 \mathrm{ft}$ bgs. The exact depth with be randomly selected. If there is refusal at a shallower depth, then additional borings will be drilled to collect the required number of samples. The depth of $12 \mathrm{ft}$ was based on the assumption that chemical contamination would not extend beyond this depth based on process knowledge, operational history, and results of the preliminary field investigation. If potential contamination is observed at deeper intervals through visual observations of soil cores and/or field screening, additional background samples will be collected for those depths. For the purposes of this investigation, the background values for inorganic parameters at all four operational areas designated for further investigations will be assumed to be the same. 


\subsubsection{Soil Sampling Techniques}

The two techniques proposed for sample collection, soil boring and excavation, are described below. In addition, this section provide details on how specific locations within a soil boring or excavation will be chosen for sampling.

\subsubsection{Soil Boring Techniques}

Drilling methods such as direct-push, rotosonic, or other appropriate drilling technique will be used for the investigative drilling and soil characterization. The direct-push method penetrates the soil with minimal disturbance, using an advancing decontaminated hollow 4-ft core barrel. Acetate, cellulose, or polyvinyl chloride liner sleeves will be used to contain the cores at each boring. In the event that an additional volume of soil is needed for analysis, additional cores will be obtained from around the original boring at a radius of not greater than $1 \mathrm{ft}$. The rotosonic method penetrates soil with minimal disturbance using an advancing, decontaminated 10-ft core barrel. The resulting soil cores can be extruded into plastic bags in convenient handling lengths (approximately $5 \mathrm{ft}$ ) for sampling.

All drilling and sample collection tools that may come in contact with soil samples shall be decontaminated prior to each sampling event to minimize potential cross-contamination between sample locations. All samples collected for laboratory analysis will be fresh media rather than material used for field screening. Records will be kept of the soil description, field-screening measurements, and other relevant data. All required sampling information (e.g., date, time, sample interval) will be documented in accordance with the NM QAPP (Appendix B) and applicable contractor standard quality practices.

\subsubsection{Soil Excavation Techniques}

Soil excavation may be used to locate septic tanks, landfills, or other anomalies not identified by geophysical investigations. Excavation techniques will be appropriate for the anticipated depth and volume of the excavation. As such, techniques may include excavation with hand tools or heavy equipment (e.g., backhoe). 
All excavation tools that may come in contact with soil samples shall be decontaminated prior to each sampling event to minimize potential cross-contamination between sample locations. Samples will be collected either directly from the bottom of the excavation or from material removed (e.g., sample may be collected from a backhoe bucket). All samples collected for laboratory analysis will be fresh media rather than material used for field screening. Records will be kept of the soil description, field-screening measurements, and other relevant data. All required sampling information (e.g., date, time, sample interval) will be documented in accordance with the NM QAPP (Appendix B) and applicable contractor standard quality practices.

Excavated material will be managed in soil piles near the excavation. The piles will be managed in a manner that is protected from run-on and run-off as the conditions require. Upon completion of investigation within each excavation, the soil will be returned to the excavation taking care to replace the soils to their approximate horizon of origin.

\subsubsection{Field Screening}

Soil samples will be collected for field screening at intervals appropriate for the method (e.g., 4-ft intervals for direct-push or 5-ft intervals for rotosonic), depth of investigation, and for the AOC being investigated. For example, TPH field screening would not be used for an AOC where TPH is not a COPC, nor would field screening be conducted every $4 \mathrm{ft}$ if contamination is obvious due to staining and/or odor. When field screening is being used to guide the investigation and select sampling locations, it will be continued until two consecutive, "clean" field-screening samples are obtained or until $10 \mathrm{ft}$ below the deepest detected contamination, whichever is deeper. If contamination is detected beyond $20 \mathrm{ft}$, or the limit of the technology is met prior to reaching $10 \mathrm{ft}$ beyond detected contamination, drilling/excavation will stop and the situation will be evaluated to determine if the contamination is outside the planned scope of the investigation.

All soil cores and excavated material will be visually inspected and screened for VOCs, using a photo-ionization detector (or similar). Samples may also be field-screened using a method capable of identifying TPH, such as the Hanby or other method. The results of field screening will be recorded on appropriate forms. Visual indications of contamination, elevated VOC readings, and/or elevated 
TPH screening, may be used to select samples for off-site analysis. The following field-screening results will be used to indicate if contamination is present:

- VOC readings of twice background (established daily) or 20 parts per million (ppm), whichever is higher

- $\quad \mathrm{TPH}$ results of $100 \mathrm{ppm}$ or greater

If contamination is detected by any of the above methods, the horizontal and vertical extent of the contamination will be defined by continuing soil borings and/or excavations until two consecutive nondetects are recorded and/or by completing step-out borings or excavations.

Site characterization field screening for radioactive constituents will not be conducted.

\subsubsection{Sampling Criteria}

Soil borings and/or excavation will be used for two primary purposes: (1) to collect soil samples from within an AOC to determine the nature and vertical extent of potential contamination, and (2) as step-out borings/excavations to determine the lateral extent of potential contamination. Unless otherwise indicated, samples will be collected as follows:

For borings/excavations that are within an AOC, a minimum of two samples will be selected for off-site laboratory analysis. One sample will be from the highest field-screening interval, and the second sample will be from the deepest vertical, nondetect interval or a minimum of $10 \mathrm{ft}$ below the deepest contamination detected by field screening, whichever is deeper. If field screening and observation does not indicate contamination in a boring drilled in a suspect area, then a sample will be collected from the interval where contamination was expected, based on field observations and process knowledge. For example, if soil below $4 \mathrm{ft}$ bgs appears to be undisturbed and soil above $4 \mathrm{ft}$ bgs appears to be fill or nonnative soil, the sample will collected above the 4 - $\mathrm{ft}$ level.

For step-out borings/excavations, if field screening does not detect any contamination, a sample from the equivalent depth interval (same depth as the contaminated boring) will be submitted for confirmation of the nondetect field-screening readings. 
Discretionary sampling points may also be selected for laboratory analysis based on observation of:

- Moist or discolored zones

- Significant changes in soil grain size or debris in sample

- Changes in field-screening detection

- Odor

Geotechnical samples may be collected for evaluation of soil parameters to facilitate future corrective action strategies.

\subsubsection{Soil Sampling Locations for Surface/Shallow Subsurface Characterization}

Each soil sampling location will be named, described, and documented in accordance with the NM QAPP (Appendix B) and applicable contractor standard quality practices. In the field, decisions will be made to allow for changes to sampling locations and number of samples collected, depending on field conditions. For example, if apparent contamination is more widespread than originally anticipated, it may be decided to expand the number of locations sampled. If bedrock or refusal is encountered at a very shallow depth, a subsurface soil sample may not be possible at that sampling location. If drilling, excavation, and/or sampling at a recommended location presents an undue health and safety risk to field personnel, the location will be changed. Changes, and the rationale behind each change, will be documented.

\subsubsection{Surface Ground Zero Area}

Known or suspect site features within the SGZ area discussed in Section 2.2.1 or found during the geophysical investigation (see Appendix C, Section C.6.0) are listed in Table 4-3. Geophysical and/or sampling results from the preliminary field investigation (Appendix C) were utilized, where applicable, to focus the COPCs and determine the proposed investigation method. These features will be investigated as summarized in Table 4-3 and described in the following sections. Historical and geophysical data have been compared to make a determination as to what geophysical anomalies represent (e.g., a known or unknown mud pit, landfill), and a unique name has been assigned. 
Table 4-3

Investigation Strategy for Surface Ground Zero Area Known and Suspect AOCs

(Page 1 of 2)

\begin{tabular}{|c|c|c|c|}
\hline Unique Identifier & $\begin{array}{l}\text { Approximate } \\
\text { Size (feet) }\end{array}$ & Summary of Proposed Investigation Strategy & $\begin{array}{l}\text { Contaminants of Potential } \\
\text { Concern }\end{array}$ \\
\hline $\begin{array}{l}\text { Well EPNG } 10-36 \\
\text { Sump }\end{array}$ & $50 \times 25$ & $\begin{array}{l}\text { Further investigation will include excavation and/or direct-push sampling to } \\
\text { refine nature and extent of potential contamination. }\end{array}$ & $\begin{array}{l}\text { TPH (DRO, GRO), VOCs, SVOCs, } \\
\text { Total RCRA metals }\end{array}$ \\
\hline Well GB-1 Mud Pit & $100 \times 50$ & \multirow{3}{*}{$\begin{array}{l}\text { Based on available historical documentation and the results of the } \\
\text { geophysical investigation, these three mud pits can not be distinguished } \\
\text { from each other. Therefore, for the purposes of further investigation, these } \\
\text { three mud pits will be treated as one unit. Further investigation will include } \\
\text { additional direct-push sampling to refine nature and extent of potential } \\
\text { contamination. }\end{array}$} & \multirow{3}{*}{$\begin{array}{l}\text { TPH (DRO, GRO), VOCs, SVOCs, } \\
\text { Total RCRA metals }\end{array}$} \\
\hline Well GB-E Mud Pit B & NA & & \\
\hline Well GB-E Mud Pit C & NA & & \\
\hline Well GB-2 Mud Pit & $150 \times 125$ & $\begin{array}{l}\text { Further investigation will include additional direct-push sampling to refine } \\
\text { nature and extent of potential contamination. }\end{array}$ & $\begin{array}{l}\text { TPH (DRO, GRO), VOCs, SVOCs, } \\
\text { Total RCRA metals }\end{array}$ \\
\hline Well GB-E Mud Pit A & $150 \times 175$ & $\begin{array}{l}\text { Further investigation will include additional direct-push sampling to refine } \\
\text { nature and extent of potential contamination. }\end{array}$ & $\begin{array}{l}\text { TPH (DRO, GRO), VOCs, SVOCs, } \\
\text { Total RCRA metals }\end{array}$ \\
\hline Well GB-E Mud Pit D & $75 \times 50$ & $\begin{array}{l}\text { Well GB-E Mud Pit D is located entirely within the lateral bounds of the } \\
\text { Well GB-2 Mud Pit, but consists of a distinct mud layer. Further investigation } \\
\text { will include additional direct-push sampling to refine nature and extent of } \\
\text { potential contamination. }\end{array}$ & $\begin{array}{l}\text { TPH (DRO, GRO), VOCs, SVOCs, } \\
\text { Total RCRA metals }\end{array}$ \\
\hline Well GB-E Mud Pit E & $100 \times 75$ & $\begin{array}{l}\text { Further investigation will include additional direct-push sampling to refine } \\
\text { nature and extent of potential contamination. }\end{array}$ & $\begin{array}{l}\text { TPH (DRO, GRO), VOCs, SVOCs, } \\
\text { Total RCRA metals }\end{array}$ \\
\hline Landfill A & $20 \times 10$ & \multirow{3}{*}{$\begin{array}{l}\text { Further investigation will include excavation and/or direct-push sampling to } \\
\text { refine nature and extent of potential contamination. }\end{array}$} & \multirow{3}{*}{$\begin{array}{l}\text { TPH (DRO, GRO), VOCs, SVOCs } \\
\text { Total RCRA metals }\end{array}$} \\
\hline Landfill C & $50 \times 10$ & & \\
\hline Landfill D & $30 \times 10$ & & \\
\hline Landfill B & $50 \times 50$ & No further investigation is proposed. & No further sampling proposed. \\
\hline Landfill E & $50 \times 20$ & No further investigation is proposed. & No further sampling proposed. \\
\hline
\end{tabular}




\section{Table 4-3}

Investigation Strategy for Surface Ground Zero Area Known and Suspect AOCs

(Page 2 of 2)

\begin{tabular}{|c|c|c|c|}
\hline Unique Identifier & $\begin{array}{l}\text { Approximate } \\
\text { Size (feet) }\end{array}$ & Summary of Proposed Investigation Strategy & $\begin{array}{l}\text { Contaminants of Potential } \\
\text { Concern }\end{array}$ \\
\hline Septic Tank A & \multirow[b]{2}{*}{ NA } & \multirow{2}{*}{$\begin{array}{l}\text { Search for septic tank with exploratory excavation. If tank is located, verify it } \\
\text { has been closed in place (filled). If tank has not been filled, sample any } \\
\text { contents, and close in accordance with State of New Mexico regulations } \\
\text { (NMAC, 1997). }\end{array}$} & \multirow[b]{2}{*}{$\begin{array}{l}\text { As required for waste disposal (tank } \\
\text { contents only) }\end{array}$} \\
\hline Septic Tank B & & & \\
\hline $\begin{array}{l}\text { Well EPNG 10-36 } \\
\text { Drill Pad }\end{array}$ & $50 \times 50$ & No further investigation is proposed. & No further sampling proposed. \\
\hline Well GB-1 Drill Pad & $50 \times 50$ & No further investigation is proposed. & No further sampling proposed. \\
\hline Well GB-2 Drill Pad & $50 \times 50$ & No further investigation is proposed. & No further sampling proposed. \\
\hline Well GB-E Drill Pad & $100 \times 100$ & No further investigation is proposed. & No further sampling proposed. \\
\hline Well GB-3 Drill Pad & $50 \times 50$ & No further investigation is proposed. & No further sampling proposed. \\
\hline Soil Pile & $75 \times 50$ & Excavate and sample based on field observations. & $\begin{array}{l}\text { TPH (DRO, GRO), VOCs, SVOCs, } \\
\text { Total RCRA metals }\end{array}$ \\
\hline Gas-Flaring System & Unknown & $\begin{array}{l}\text { Further investigation will include additional direct-push sampling to refine } \\
\text { nature and extent of potential contamination. }\end{array}$ & $\begin{array}{l}\text { TPH (DRO, GRO), VOCs, SVOCs, } \\
\text { Total RCRA metals }\end{array}$ \\
\hline
\end{tabular}

$\mathrm{DRO}=$ Diesel-range organics

$\mathrm{GRO}=$ Gasoline-range organics

$\mathrm{NA}=$ Not applicable 


\section{EPNG 10-36 Sump}

The geophysical survey conducted in August 2000 identified an anomaly with both a strong metallic and nonmetallic signature where this feature was predicted. It is unknown what may be producing the metallic response. No drilling mud was observed in a boring (GBP06) drilled in the center of the anomaly during the preliminary field investigation. No COPCs were detected above PALs in samples collected from the boring.

Excavation and/or soil boring is proposed to further investigate this anomaly. If excavation is used, a minimum of one trench will be excavated perpendicular to the long axis of the anomaly. If soil boring is used, a minimum of two additional soil borings will be drilled within the anomaly. Field screening and observation will be used to guide sample collection as described in Section 4.2.2.

\section{Mud Pits}

Samples will be collected to characterize the materials present within each of the mud pits or groups of mud pits identified for further investigation in Table 4-3. Although Well GB-E Mud Pit D lies entirely within the bounds of the Well GB-2 Mud Pit, it will be treated as a separate AOC. This is based on the findings of the preliminary field investigation, which indicated there are two distinct layers of potential contamination. Even so, the investigation of these mud pits will share some boreholes.

The Well GB-2 Mud Pit and Well GB-E Mud Pit A are currently separated by a berm. This berm is assumed to represent the west and east boundaries, respectively, of these mud pits.

Based on the results of the historical research, coupled with the findings of the geophysical investigation, it is assumed that one or more of the mud pits identified in Table 4-3 were used for the containment of drilling fluids for the reentry of wells EPNG 10-36, GB-2R, and GB-ER, and for the initial drilling of Well GB-3. Therefore, additional investigation for separate mud pits for these drilling events will not occur unless further evidence identified during the field investigation indicates it is necessary.

To more accurately determine the nature and vertical extent of contamination, additional boreholes will be drilled within each mud pit or group of mud pits. Five boreholes (boreholes already drilled 
during the preliminary field investigation are counted towards the total) will be drilled within each mud pit or group of mud pits. Results of the geophysical investigation, together with historical site knowledge, will be used to define the perimeters of each mud pit. The estimated dimensions in Table 4-3 will be used to randomly select additional borehole locations.

A borehole will be drilled at each of the pre-selected locations. A sample will be collected from any identified mud layer encountered. Mud layers encountered during the preliminary field investigation were generally less than $2 \mathrm{ft}$ in thickness and transitional at both the top and bottom of the layer. The sample will be collected by homogenizing the interval identified as the mud layer. Field screening will be used to determine the depth to which contamination extends below the mud layer, if at all (results from the preliminary field investigation indicate that migration of TPH from the mud layer is not occurring). A sample will be collected at this point for confirmation that the extent of contamination has been defined. Field screening will be continued until two consecutive "clean" field-screening samples are obtained or until $10 \mathrm{ft}$ below the deepest detected contamination, whichever is deeper, and a sample will be collected at this point. If no mud layer is encountered and field screening does not indicate contamination, a sample will be collected at the depth where mud was expected to be encountered (based on where it was encountered in other boreholes within the mud pit) and at $10 \mathrm{ft}$ below this level. See Figure 4-2 for an example of sampling locations.

Borings will also be advanced outside of the estimated lateral extent of contamination. If no mud is observed by visual inspection, and field screening does not indicate any contamination, it will be assumed the edge of the contamination has been defined. If mud is observed, it will be assumed the borehole was located within the AOC and a step-out location will be selected for another borehole. Samples for laboratory analysis may not be collected from step-out borings for mud pits.

\section{Landfills}

The geophysical investigation did not identify any of the four landfills (Landfill A, B, C, or D) documented during the 1978 site remediation (EIC, 1979). Based on historical documentation, Landfill B contains only nonhazardous and nonradioactive construction debris and will not be investigated further. The historical diagram documenting the location of Landfills A, C, and D will be used to stake their predicted locations. Excavation is proposed to further investigate these landfills. 

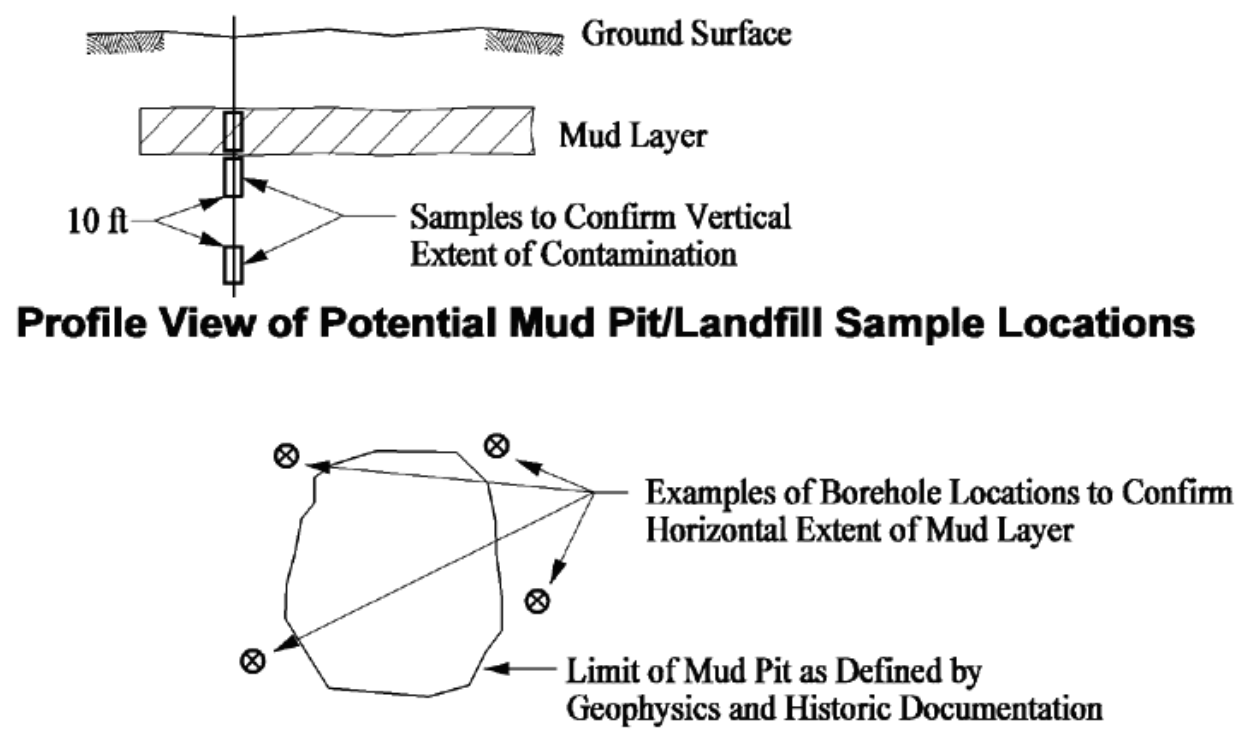

Plan View of Potential Mud Pit Boring Locations

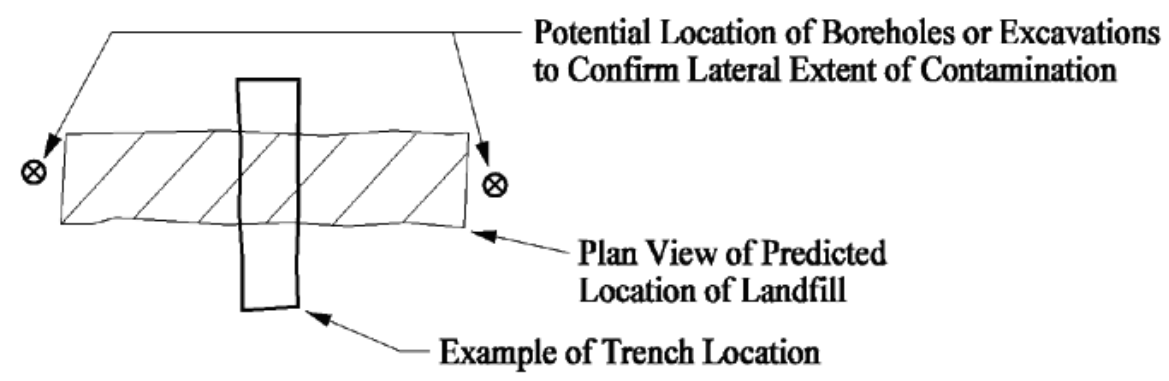

Plan View of Potential Borehole or Excavation Locations

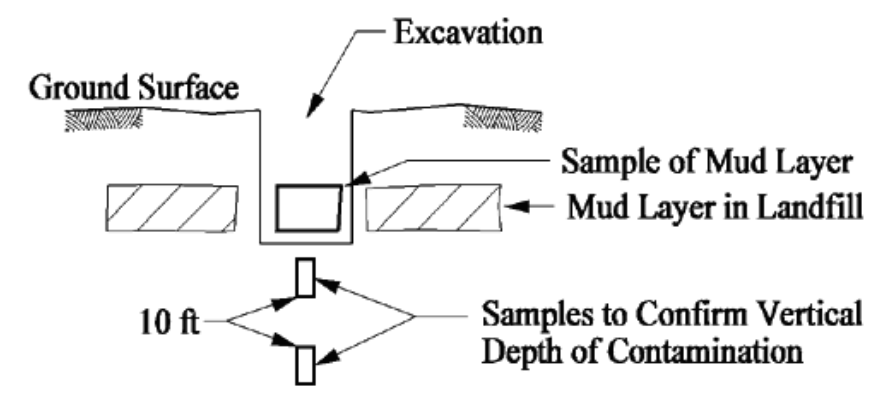

Mud Layer

\section{Profile View of Potential Landfill Sample Locations}


Trenches will be excavated at the estimated center and perpendicular to the long axis of each landfill. Sampling will be conducted as described in Section 4.2.2. Because these landfills were used to dispose of drilling fluids previously held in tanks, it is assumed the contents of each of the landfills are homogenous. Therefore, one sample will be considered representative of the contents. The lateral extent of each landfill will be defined by visual observation and/or sampling in the same manner as described for mud pits. The vertical extent of potential contamination will also be defined in the same manner as described for mud pits. If no mud is found, then step-out trenches will be excavated $10 \mathrm{ft}$ to either side of the original trench. This will continue until the landfill is identified or to a maximum of $50 \mathrm{ft}$ laterally from predicted center line, whichever comes first. See Figure 4-2 for example of trench and sample locations.

Several anomalies were located where Landfill E was indicated in historical photographs. Based on the results of the preliminary field investigation (Appendix C, Section C.6.0), it is assumed this landfill contains only metal and/or other construction debris and will not be investigated further.

\section{Septic Tanks}

The geophysical survey was unable to definitively locate the septic tanks identified in the historical documentation (Figure 2-8). Excavation will be used to attempt to locate the septic tanks, where they are indicated by historical documentation. If excavation fails to locate the septic tanks, it will be assumed they were either never constructed, were closed in place in accordance with State of New Mexico regulations, or were removed, and investigation of the tank will be discontinued. If the location of a septic tank is identified, further investigation will be conducted as follows.

The septic tank lid, if one exists (the construction of the tanks is not known), will be excavated so that confirmation can be made that the tank was closed (e.g., filled with earth, sand, gravel, or concrete) in accordance with New Mexico regulations, Title 20 NMAC 7.3.410, “Abandoned Sewers and On-Site Liquid Waste Systems" (NMAC, 1997). If the tank was not filled and still contains any material that can be sampled, a sample will be collected and analyzed for the parameters necessary to dispose of any remaining waste. The waste will be removed and the tank closed in accordance with New Mexico regulations (NMAC, 1997). 


\section{Drill Pads}

Based on the results of the preliminary field investigation, no additional investigation of the drill pads is planned (see Appendix C).

\section{Soil Pile}

During the preliminary field investigation, a soil pile was noted approximately $200 \mathrm{ft}$ north of Well EPNG 10-36 at the northern boundary of the SGZ area. The origin of this pile is not known. Geophysical surveys indicated a scatter of small nonmetallic anomalies within this pile (possibly pieces of concrete). This pile is not visible in historical photos taken prior to filling of the Well GB-E mud pits (November-December, 1967), and may be a result of the grading conducted in the SGZ area prior to the detonation.

Investigation of the pile will be conducted by excavating a trench through the pile. Field screening and observation will be used to guide sample collection, as described in Section 4.2.2. If contamination is found, the extent will be defined in the same manner as that described for the mud pits. If no potential contamination is observed through field screening and visual observation, samples may not be required for laboratory analysis.

\section{Flare Stack Area}

Diesel, gasoline, and 1,2,4-trimethylbenzene were detected in samples collected during the preliminary field investigation at the historic location of the flare stack (see Appendix C). Additional direct-push sampling is proposed to further refine the nature and extent of potential contamination in this area. A minimum of three step-out boreholes will be drilled approximately $10 \mathrm{ft}$ from the flare stack location. Field screening and observation will be used to guide sample collection as described in Section 4.2.2.

\subsubsection{Well GB-D Area}

Known or suspect site features discussed in Section 2.2.2, or found during the geophysical investigation (see Appendix C, Section C.3.4.2), and that require further investigation are listed in Table 4-4. The dimensions of the mud pit will be used to randomly select five locations within the 
mud pit where soil borings will be located. Investigation of the mud pit will be the same as that described in Section 4.2.3.1 for the investigation of the SGZ area mud pits.

The origin of the nonmetallic Well GB-D Anomaly B, identified by geophysics is not known. The soil pile near this anomaly suggests a possible excavation and fill event; thus, the anomaly warrants further investigation. The estimated dimensions of the anomaly will be used to randomly select four locations within the anomaly, where soil borings will be located. Samples will be collected as described in Section 4.2.2. Evidence of soil disturbance and/or field-screening results will be used to locate sample collection points. If no contamination is indicated by field screening and there is no evidence of soil disturbance within the anomaly, then confirmation samples will be collected at a single randomly selected depth between 2 and $12 \mathrm{ft} \mathrm{bgs} \mathrm{within} \mathrm{each} \mathrm{boring.} \mathrm{If} \mathrm{potential}$ contamination is observed or detected by field screening, step-out borings will be used to define the extent of the contamination.

Soil borings will also be completed at a minimum of three locations around Well GB-D to investigate potential releases on the pad. Field screening will be used to guide the investigation. The lateral extent of contamination will be defined with step-out borings, as necessary.

Table 4-4

Well GB-D Area Known and Suspect AOCs to be Further Investigated

\begin{tabular}{|c|c|l|l|}
\hline $\begin{array}{c}\text { Unique } \\
\text { Identifier }\end{array}$ & $\begin{array}{c}\text { Approximate } \\
\text { Size (feet) }\end{array}$ & \multicolumn{1}{c|}{$\begin{array}{c}\text { Summary of Proposed Investigation } \\
\text { Strategy }\end{array}$} & $\begin{array}{c}\text { Contaminants of } \\
\text { Potential Concern }\end{array}$ \\
\hline \hline $\begin{array}{c}\text { Well GB-D } \\
\text { Mud Pit }\end{array}$ & $80 \times 40$ & $\begin{array}{l}\text { Investigation will include direct-push sampling } \\
\text { to define nature and extent of potential } \\
\text { contamination. }\end{array}$ & $\begin{array}{l}\text { TPH (DRO, GRO), VOCs, } \\
\text { SVOCs, Total RCRA metals }\end{array}$ \\
\hline $\begin{array}{c}\text { Well GB-D } \\
\text { Anomaly B }\end{array}$ & $100 \times 75^{\mathrm{b}}$ & $\begin{array}{l}\text { Investigation will include direct-push sampling } \\
\text { to define nature and extent of potential } \\
\text { contamination. }\end{array}$ & $\begin{array}{l}\text { TPH (DRO, GRO), VOCs, } \\
\text { SVOCs, Total RCRA metals }\end{array}$ \\
\hline $\begin{array}{c}\text { Well GB-D } \\
\text { Drill Pad }\end{array}$ & $50 \times 50$ & $\begin{array}{l}\text { Investigation will include direct-push sampling } \\
\text { to define nature and extent of potential } \\
\text { contamination. }\end{array}$ & $\begin{array}{l}\text { TPH (DRO, GRO), VOCs, } \\
\text { SVOCs, Total RCRA metals }\end{array}$ \\
\hline
\end{tabular}

${ }^{a}$ Anomalies identified by geophysical surveys are listed by the unique identifiers assigned to them in the report on the results of the geophysical survey (SAIC, 2000). Not all anomalies identified by geophysics require further investigation (Appendix C).

${ }^{\mathrm{b}}$ Anomaly extends beyond western edge of surveyed area. 


\subsubsection{Recording Trailer Park}

Suspect site features within the RTP found during the geophysical investigation (see Appendix C, Section C.3.4.3) and that require further investigation are listed in Table 4-5. There were no features documented in the historical information that required further investigation. Based on the results of the geophysical survey, Anomaly $\mathrm{G}$ appears to be a burial trench for metallic and possibly other construction debris. The estimated dimensions of the anomaly will be used to randomly select a minimum of two locations within the anomaly where soil borings will be located. Samples will be collected as described in Section 4.2.2. Evidence of soil disturbance and/or field-screening results will be used to locate sample collection points. If no contamination is indicated by field screening and there is no evidence of soil disturbance within the anomaly, confirmation samples will be collected at a single randomly selected depth between 2 and $12 \mathrm{ft}$ bgs. within each boring. If potential contamination is observed or detected by field screening, step out borings will be used to define the extent of the contamination.

Table 4-5

Recording Trailer Park Known and Suspect AOCs to be Further Investigated

\begin{tabular}{|c|c|l|c||}
\hline $\begin{array}{c}\text { Unique } \\
\text { Identifier }\end{array}$ & $\begin{array}{c}\text { Approximate } \\
\text { Size (feet) }\end{array}$ & \multicolumn{1}{|c|}{$\begin{array}{c}\text { Summary of Proposed Investigation } \\
\text { Strategy }\end{array}$} & $\begin{array}{c}\text { Contaminants of } \\
\text { Potential Concern }\end{array}$ \\
\hline \hline $\begin{array}{c}\text { RTP } \\
\text { Anomaly Ga }\end{array}$ & $50 \times 30$ & $\begin{array}{l}\text { Investigation will include direct-push sampling } \\
\text { to define nature and extent of potential } \\
\text { contamination. }\end{array}$ & $\begin{array}{l}\text { TPH (full scan), VOCs, } \\
\text { SVOCs, Total RCRA metals }\end{array}$ \\
\hline
\end{tabular}

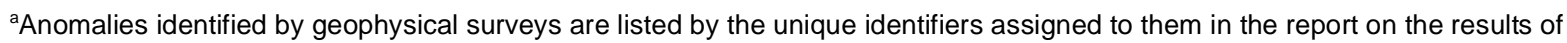
the geophysical survey (SAIC, 2000). Not all anomalies identified by geophysics require further investigation (Appendix C).

\subsubsection{Control Point}

Known or suspect site features within the CP discussed in Section 2.2.4, or found during the geophysical investigation (see Appendix C, Section C.3.4.4) and that require further investigation, are listed in Table 4-6. The septic tank indicated in historical site drawings (Figure 2-13) will be investigated in the same manner as that described for the septic tanks in the SGZ area (Section 4.2.3.1). It is unknown what Anomaly E represents (see Appendix C, Section C.3.4.4). Based on the proximity of this anomaly to the location of a mobile radiological laboratory, as 
Table 4-6

Control Point Known and Suspect AOCs to be Further Investigated

\begin{tabular}{|c|c|l|l||}
\hline $\begin{array}{c}\text { Unique } \\
\text { Identifier }\end{array}$ & $\begin{array}{c}\text { Approximate } \\
\text { Size (feet) }\end{array}$ & Summary of Proposed Investigation Strategy & $\begin{array}{c}\text { Contaminants of } \\
\text { Potential Concern }\end{array}$ \\
\hline \hline $\begin{array}{c}\mathrm{CP} \\
\text { Anomaly Ca } \\
\text { (septic tank) }\end{array}$ & NA & $\begin{array}{l}\text { Search for septic tank with exploratory excavation. If tank } \\
\text { is located, verify it has been closed in place (filled). If tank } \\
\text { has not been filled, sample any contents, and close } \\
\text { according to New Mexico regulations (NMAC, 1997). } \\
\text { Sample location(s) will be chosen based on site } \\
\text { observations. }\end{array}$ & $\begin{array}{l}\text { As required for waste } \\
\text { disposal (septic tank } \\
\text { contents only) }\end{array}$ \\
\hline $\begin{array}{c}\text { CP } \\
\text { Anomaly Ea }\end{array}$ & $20 \times 5$ & $\begin{array}{l}\text { Investigation will include direct-push and/or excavation } \\
\text { sampling to define nature and extent of potential } \\
\text { contamination }\end{array}$ & $\begin{array}{l}\text { TPH (DRO, GRO), } \\
\text { VOCs, SVOCs, Total } \\
\text { RCRA metals }\end{array}$ \\
\hline
\end{tabular}

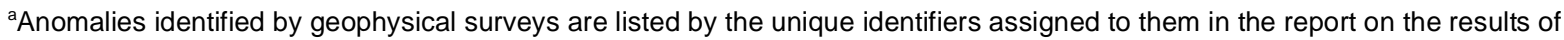
the geophysical survey (SAIC, 2000). Not all anomalies identified by geophysics require further investigation (Appendix C).

indicated in historical site photos, this anomaly will be further investigated. No other investigation or soil sampling is planned for this area.

\subsubsection{Quality Control Samples}

Quality control samples at the Gasbuggy Site will be collected, labeled, handled, and shipped to the laboratory in accordance with the NM QAPP located in Appendix B of this document and the contractor procedures.

\subsubsection{Analysis}

COPCs at the Gasbuggy Site, as mentioned in Section 3.2, are related primarily to constituents in the drilling mud and associated with drilling operations. Laboratory chemical, TCLP, and radiochemistry analytical requirements that may be used for the site characterization and waste characterization samples are specified in Appendix B.

\subsection{Shallow Groundwater Investigation}

Depth to shallow groundwater has not been established at the Gasbuggy Site. Therefore, investigation of shallow groundwater will be based on observations made during the field investigation. 
Soil borings and/or excavations in which contamination is detected by direct observation or field-screening methods will be extended a minimum of $10 \mathrm{ft}$ beyond the deepest contamination detected. If groundwater is located either in contact with contaminated soil or within $10 \mathrm{ft}$ of contaminated soil (as determined in the field), then the groundwater in the source area will be sampled and the background conditions for shallow groundwater will be established.

\subsubsection{Well Installation and Groundwater Monitoring}

Groundwater monitoring shall be performed if it is determined that contamination from mud pits or other sources intercepts the shallow groundwater table or contaminant migration may be occurring through the soil to the shallow groundwater table. One background monitoring well will be installed in an area of the site that is hydraulically upgradient from any potential on-site contamination which may have resulted from past site activities. The location will be determined from site investigations.

The background well and other monitoring wells will be drilled utilizing an appropriate drilling technique, and the wells installed in accordance with the State of New Mexico monitoring well regulations. The depths for these wells are dependent upon the depth to shallow groundwater, but it is anticipated that total depth will be less than $100 \mathrm{ft}$ bgs. The number and location of monitoring wells will be determined based on location of contamination, calculated flow gradient, and discussion with NMED. Soil boring logs and a well completion diagram for each well installed will be prepared. Water-level measurements will be taken when the well has been completed, developed, and has had a sufficient amount of time to equilibrate. All well locations and elevations will be surveyed at the completion of characterization activities.

\subsection{Additional Requirements and Activities}

The requirements and activities described in this section apply to both surface and subsurface investigations.

\subsubsection{Health and Safety}

All site preparations and work activities will be conducted in a manner that is protective of the safety and health of site workers, the public, and the environment. Site workers are encouraged to utilize the best available methods to perform job functions in supporting field activities. Standard work 
practices and procedures are designed to comply with all relevant and applicable federal, state, and local regulatory agencies.

Operations conducted at the Gasbuggy Site will be conducted in accordance with the primary Real Estate and Operations Permit holder's fully developed health and safety program. This program places the emphasis for the health, safety, and environmental protection on the company management team and the associates doing the work. The "safety first" philosophy is passed down from the management to the associates as the best method of doing business. The health and safety program and philosophy fully supports the DOE Integrated Safety Management System, and is maintained through a system of inspections, audits, and reviews of field activities as they occur.

A site-specific health and safety plan (SSHASP) will be developed defining the scope of work to be conducted at Gasbuggy Site to identify the particular features, hazards, communication methods, responsibilities, and protective measures to be employed on site. Controls will be developed and implemented to minimize or eliminate identified hazards. The provisions of this plan are mandatory for all personnel assigned to the field project. Visitors are also required to abide by these procedures. The SSHASP is a living document and may be amended as necessary to deal with new hazards and changing conditions. Changes to the document may be verbal or written after obtaining the approval of the signatories to the original SSHASP. In addition, these changes may only be implemented after being discussed with the affected personnel on site.

\subsubsection{Environmental Compliance and Waste Management}

Contractor personnel will comply with applicable environmental compliance and waste management regulations and requirements in the conduct of site activities. A designated contractor shall be responsible for the on-site management and ultimate disposal of all waste generated as a result of the Gasbuggy Site characterization investigations. Waste will be managed on site in accordance with state and federal regulations. Soil waste from the mud pits may be managed and disposed of as excluded waste under the oil and natural gas industry-specific exclusion found in 40 CFR 261.4(b)(5) (CFR, 1999a). Personnel must comply with waste management and environmental compliance policies and procedures established for the Gasbuggy Site. 


\subsubsection{National Environmental Policy Act Requirements}

In accordance with the U.S. Department of Energy, Nevada Operations Office (DOE/NV), National Environmental Policy Act (NEPA) compliance program, a NEPA checklist shall be completed prior to commencement of site investigation activities at the Gasbuggy Site. This checklist compels $\mathrm{DOE} / \mathrm{NV}$ to evaluate this proposed project against a list of several potential environmental impacts which include, but are not limited to: air quality, chemical use, waste generation, noise levels, and land use. Completion of the checklist results in a determination of the appropriate level of NEPA documentation by the DOE/NV NEPA Compliance Officer for this project.

\subsubsection{Quality Assurance}

All investigation activities will be completed in accordance with, planning documents, standardized operating procedures, quality practices, and the procedures established in the NM QAPP. This plan describes the measures that will be taken to ensure the quality of field sample collection, storage, transport, analytical activities and modeling associated with environmental data collection for the Gasbuggy Site investigation. This plan is located in Appendix B.

\subsubsection{Community/Stakeholder Involvement}

As part of the Gasbuggy Site investigation, DOE/NV will interface with NMED to establish the scope for the site's activities. Additional stakeholder involvement will also be part of the scoped activity and may include public/town hall meetings, informational and technical briefings and presentations, and document reviews. Stakeholders identified throughout the scoped activity will be solicited to participate in designated activities as identified by DOE/NV.

Cooperation with the USFS will be sought based on the locality of the site. Although the majority of the site (SGZ area) is located on lands officially withdrawn for AEC/DOE use, the smaller operational areas (e.g., RTP, CP) are not on withdrawn land. In addition, the site is surrounded by National Forest lands and access to the site is gained on Forest Service and/or Jicarilla Apache Reservation roads.

An effort will also be made to notify the Jicarilla Apache Tribal Council of planned activities at the Gasbuggy Site due to the proximity of the reservation to the site. 


\subsection{Subsurface Work Plan}

There is no technology currently known to remediate underground nuclear cavities. The approach of the subsurface investigation is to use existing data to support a subsurface transport model (and dose assessment, if necessary) to evaluate, if existing subsurface intrusion restrictions are sufficient for the protection of human health and the environment. Figure 5-1 is a DQO decision flow chart that summarizes the characterization scope of work and technical approach for the subsurface investigation. It is assumed that there are sufficient data available to complete the subsurface investigation, although additional data may be collected if a reduction in model uncertainty is needed.

From the three possible migration pathways (Section 3.1.2), two potential exposure routes from the underground nuclear cavity have been identified: (1) gas-phase migration through the Pictured Cliffs Formation and (2) groundwater migration through the Ojo Alamo aquifer.

Gas-phase migration through the Pictured Cliffs is the focus of the subsurface modeling effort. The potential migration pathway is transport of radionuclide-contaminated natural gas resulting from the development of the surrounding natural gas field. The region of interest will include the nuclear cavity and surrounding area, extending outward to a radius to be determined through the modeling effort. The subsurface modeling effort will be used to:

- Predict the nature and extent of contamination in the subsurface.

- Develop likely scenarios for future resource development and determine the impact of the scenarios on the extent of contamination.

- Evaluate the modeled extent of contamination relative to the subsurface intrusion (drilling) restrictions.

Groundwater migration through the Ojo Alamo aquifer is not a likely exposure route based on the physical constraints of the system (i.e., the pressure gradient opposes transport from the cavity to the Ojo Alamo). The results of a transport analysis performed by DRI (1996a and b) indicate that groundwater velocities in the Ojo Alamo are very low. In addition, the Ojo Alamo aquifer is not of 


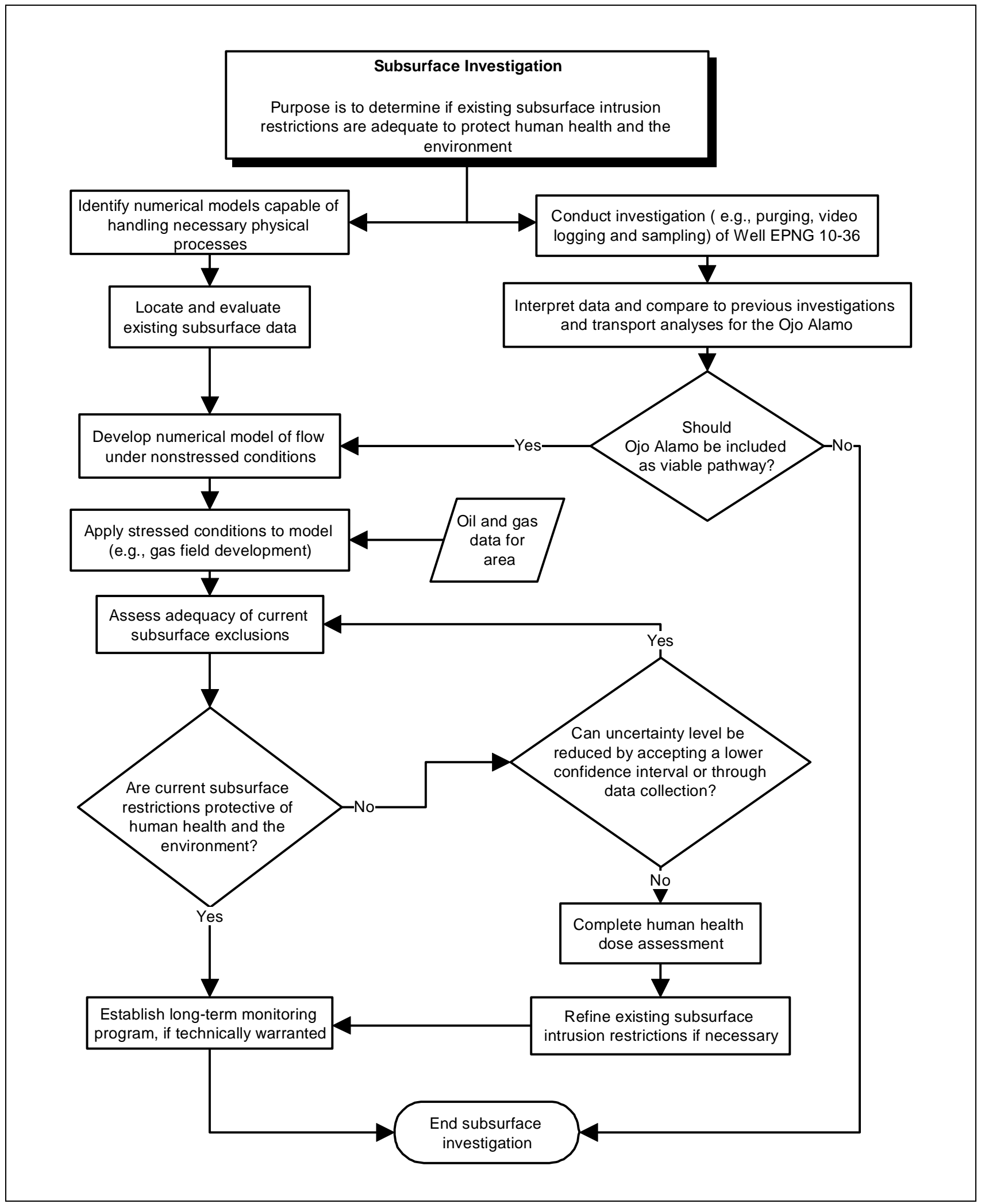

Figure 5-1

Subsurface DQO Decision Flow Chart 
drinking water quality. Sulfate in the Ojo Alamo at Well EPNG 10-36 is over 5,000 mg/L (DRI, 1996b), whereas the standard for domestic supply in New Mexico is $600 \mathrm{mg} / \mathrm{L}$ (NMAC, 1996a). A groundwater exposure route is discussed below and additional field data collection is planned; however, this is not the primary objective of the subsurface investigation. The objectives of the anticipated groundwater data collection effort are:

- Video log the well to determine if the casing integrity has been compromised, thereby allowing water to enter the well at locations in addition to the perforations.

- Determine if contamination is entering Well EPNG 10-36 from the Ojo Alamo through the perforations at the bottom of the well, or through a breach in the integrity of the casing at another level.

- Collect hydraulic data for the site with a recovery analysis for the Ojo Alamo at Well EPNG 10-36.

In addition, data gained during the investigation may be used in making decisions regarding well abandonment and monitoring.

\subsection{Conceptual Model of Subsurface Flow and Transport}

The following sections include a more detailed conceptual model for the subsurface based on specifics of the site geology, hydrology, and the phenomenology of an underground nuclear test.

\subsubsection{Geologic and Hydrogeologic Setting}

The Gasbuggy Site is in the San Juan Basin, a large structural basin containing approximately $12,000 \mathrm{ft}$ of sedimentary rocks (Figure 5-2). The detonation occurred in the Lewis Shale Formation at a depth of 4,240 ft bgs. The test was designed to fracture the Pictured Cliffs, a gas reservoir directly overlying the Lewis Shale. The Pictured Cliffs Formation at the Gasbuggy Site is bounded by the 100-ft thick overlying Fruitland Formation comprised of sandstone, shale, and siltstone, and the underlying Lewis Formation of over 1,500 ft of shale (Figure 5-3).

The Pictured Cliffs sandstone is one of the San Juan Basin's major gas reservoirs. It is a marine sandstone, grayish white, fine- to medium-grained, angular to subrounded, and cemented with bentonitic clays (Peterson et al., 1965). In its productive areas, the permeability averages 

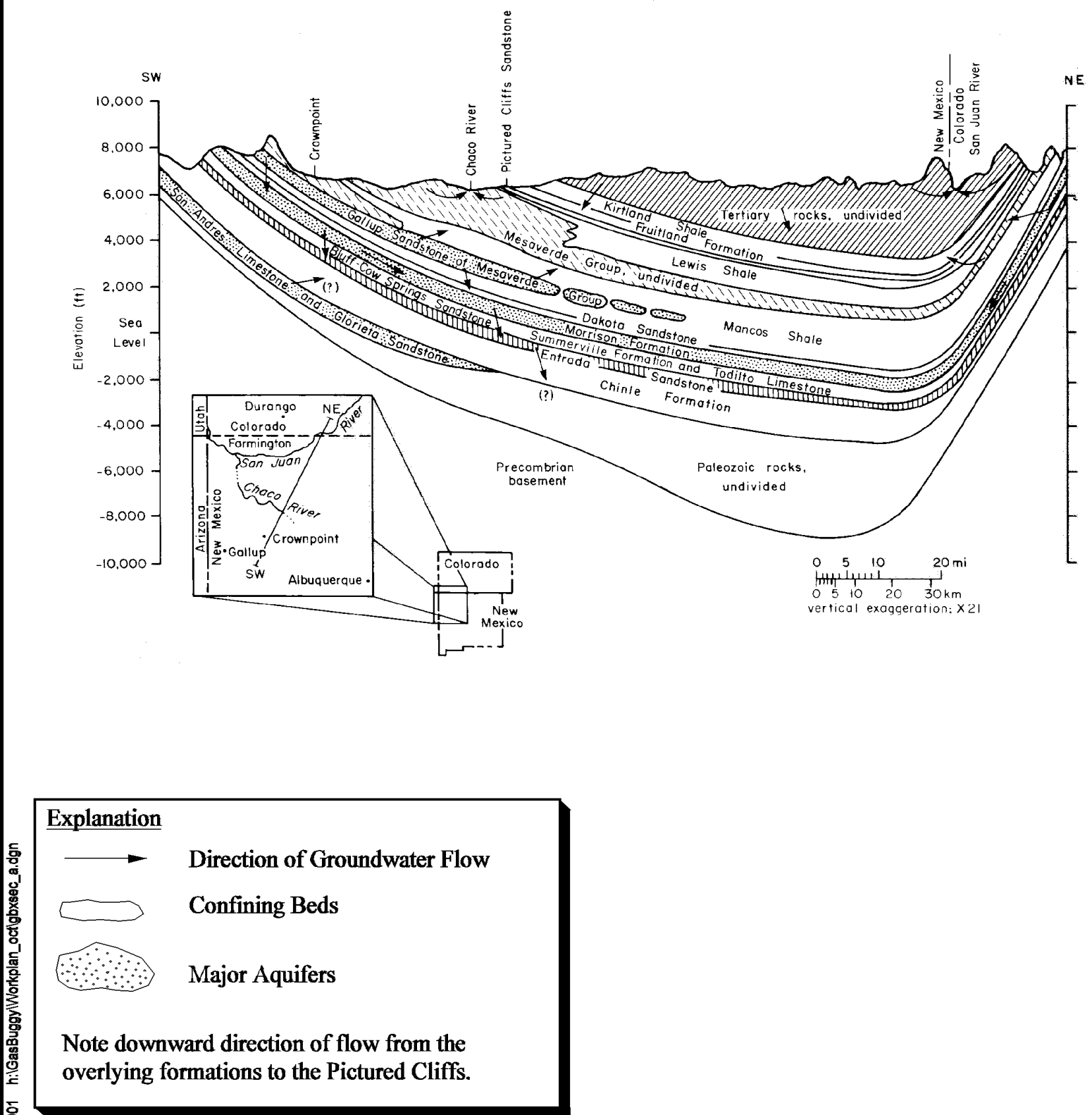

Source: New Mexico Bureau of Mines and Mineral Resources, 1983

Figure 5-2

Generalized Hydrogeologic Cross Section of the San Juan Basin 


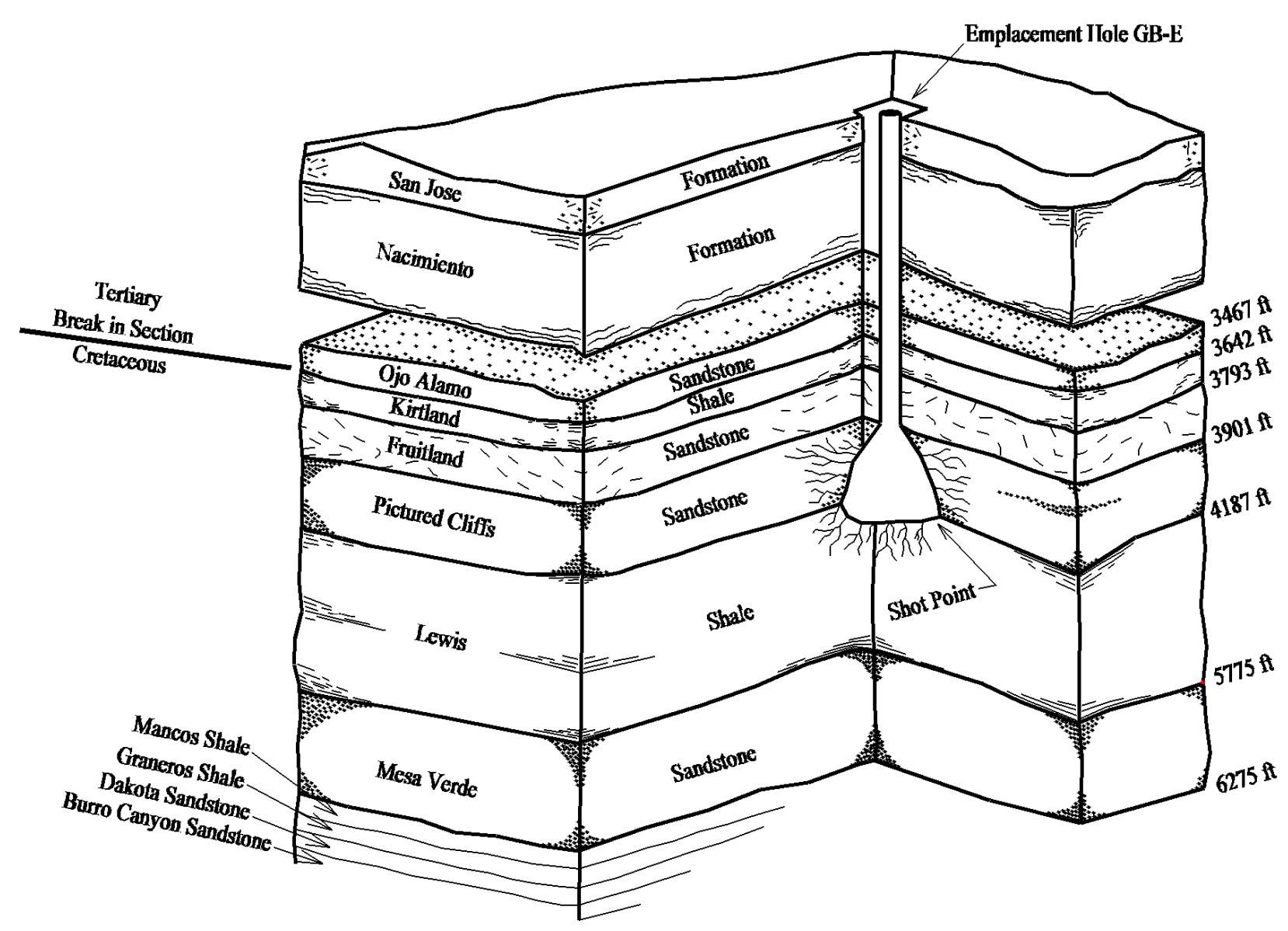

Source: DOE, 1986

Figure 5-3

Generalized Cross Section of Project Gasbuggy Emplacement Hole 
2.96 millidarcies (md), with a porosity averaging 0.18 and an average water saturation of 44 percent. In the part of the San Juan Basin where the Gasbuggy test was conducted, the Pictured Cliffs is a low-productivity, sparsely developed reservoir with a thickness of about $300 \mathrm{ft}$. Prior to the test and based on data from the nearby region, the permeability of the Pictured Cliffs was estimated to be $0.14 \mathrm{md}$, porosity 0.11 , gas saturation 0.41 , formation pressure 1,260 pounds per square inch (psi), formation temperature of 117 degrees Farenheit $\left({ }^{\circ} \mathrm{F}\right)$, and net pay thickness $190 \mathrm{ft}$ (Ward et al., 1966). Data from two on-site exploration wells (i.e., wells GB-1 and GB-2) (Figure 5-4), indicated an average permeability of $0.175 \mathrm{md}$, porosity of 0.12 , gas saturation of 0.53 , pressure of $1,012 \mathrm{psi}$, temperature of $130^{\circ} \mathrm{F}$, and net thickness of $155 \mathrm{ft}$ (Atkinson and Ward, 1967).

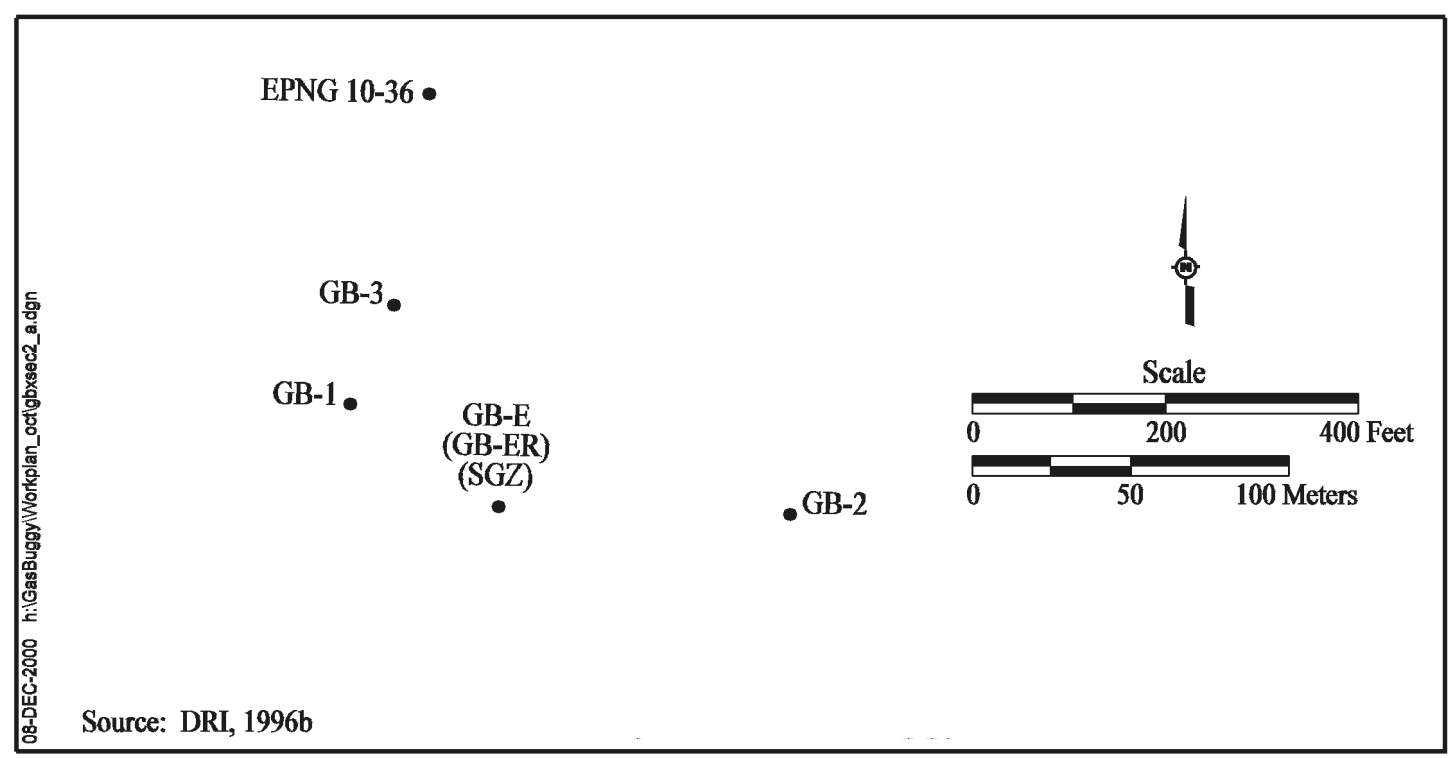

Figure 5-4 Location of Wells in the Immediate Vicinity of the Gasbuggy Test

The San Jose and Nacimiento formations produce water at the Gasbuggy Site, but are far above the zone of possible influence from the test. No significant natural connections are believed to exist between any of the water-bearing strata at the Gasbuggy Site (Sokol, 1970). The Ojo Alamo sandstone, the only aquifer of concern at the site, is separated from the Pictured Cliffs by the Fruitland sandstone and the Kirtland shale. The Ojo Alamo is a fine- to medium-grained, clayey Tertiary sandstone containing minor shale beds (Mercer, 1967). The bottom of the Ojo Alamo is approximately $600 \mathrm{ft}$ above the working point of the test. The top of the Ojo Alamo is approximately $3,465 \mathrm{ft}$ bgs, and the potentiometric surface is approximately $985 \mathrm{ft}$ bgs. Although randomly oriented 
joints present throughout the San Juan Basin may conduct some groundwater flow, pore flow is believed to dominate in the Ojo Alamo. The primary recharge area for the aquifer is probably in the southeastern portion of the basin, with flow westward or northwestward toward the San Juan River (Sokol, 1970).

\subsubsection{Description of the Gasbuggy Test and Its Effects}

The 29-kt Gasbuggy detonation (DOE/NV, 1994b) created a cavity of approximately 80 to $88 \mathrm{ft}$ in radius, with a chimney of approximately $333 \mathrm{ft}$ in height. The chimney was created by collapse and bulking of overlying material into the cavity, after the gases cooled and condensed (Holzer, 1970). Observations of cable and casing breaks in wells GB-1 and GB-ER indicated distances for fracturing of $480 \mathrm{ft}$ and $444 \mathrm{ft}$. A strong influence of geologic weaknesses and discontinuities on fracture extent was evident, with the lower portion of the Pictured Cliffs more extensively fractured than the upper part, which was apparently protected by an intervening coal and shale layer (Holzer, 1970).

A compressional shock wave created by an underground nuclear explosion travels to land surface, causing a temporary rise in surface elevation. Surface spall can occur where the surface layers split away under the influence of tensile reflections from the surface and subsequent slap-down when the layers fall. This can result in fracturing of the near surface rock, confined to the upper tens to several hundreds of feet below land surface and unconnected to fractures from the cavity.

Permeability enhancement as a result of the nuclear test was below expectations. Testing revealed lower than expected production performance, which was attributed to the following factors:

(1) overestimation of formation permeability prior to the test; (2) closing of newly created, unsupported fractures; and (3) sealing of the cavity walls by solidified melt glass (Stosur, 1977). Although permeability in the region within one cavity radius of the chimney may have increased by a factor of up to 100 over the pretest permeabilities, the fracture zone is relatively small compared to the surrounding, contributing reservoir, with production ultimately limited by that unaffected zone.

Although the stemming plan was designed to seal the emplacement well and prevent any leakage from the test, a small amount of radioactivity was detected at ground surface about eight hours after the detonation. The leakage apparently occurred in the explosive arming and firing cable with breaks in that cable possibly allowing radioactive gas to leak to porous portions of the stemmed 
emplacement hole (LRL, 1968a). After 1-1/2 hours, all cables were cut and sealed at the wellhead (LRL, 1968b). Analysis of a sample of the gas leaking up the cables determined the only radioactive materials present were inert noble gases (i.e., krypton and xenon) (AEC, 1971). Wet stemming material encountered on reentry indicated that water migrated upward under hydrostatic pressure from the Ojo Alamo (at 3,550 ft bgs) to at least 3,260 ft bgs and possibly up as far as 3,029 $\mathrm{ft}$ bgs. This water leak was attributed either to poor cement bonding in the stemming and/or explosion-caused grout failure (LRL, 1968a). Downward water migration into the chimney and cavity also occurred. Investigations into the unexpected amount of water encountered during gas production testing determined that the chemistry matched that of the Ojo Alamo groundwater (Power and Bowman, 1970). Hydraulic analysis and well history indicated leaks along the emplacement casing to be the pathway.

As in all underground nuclear tests, the majority of the radioactivity is contained in the melt glass in the bottom of the cavity. Krypton-85 and tritium account for essentially all of the radioactivity in the natural gas produced from the Gasbuggy chimney. About $350 \pm 20$ curies of $\mathrm{Kr}-85$ and about $4.5 \times 10^{4}$ curies of tritium were deposited by the explosion. The short-lived isotopes of Xe-133 and Ar-37 were also detected but have since decayed away. In addition, minor amounts of Ar-39 and C-14 were detected (Holzer, 1970). Significant quantities of radionuclides were removed by gas flow testing. The tritium was found in the form of tritiated methane, some higher hydrocarbon fractions, tritiated hydrogen, as well as tritiated water. Only five percent of the total estimated tritium was found in the gas phase. It is assumed that the remaining tritium is in water.

\subsubsection{Conceptual Model for Contaminant Transport Through the Pictured Cliffs}

Pores in the Pictured Cliffs are filled with both gas and water, almost half-and-half according to the site-specific data. Oil, if present, will be disregarded as an active phase. In models of two-phase flow through fractured rock, it is commonly assumed that the fracture spacing is larger than the pore spacing. This results in fractures containing only a mobile gas phase, while the porous medium contains both gas and liquid (water) phases (Wang and Narasimhan, 1985). This distribution of phases in the rock is derived from considerations of capillarity from the Laplace-Young equation (Adams and Gast, 1997). Both phases are assumed to be continuous throughout the reservoir; they flow in response to pressure gradients of each phase. 
Tritium produced by Gasbuggy exists in both the liquid and gas phase, and is capable of being exchanged between phases. In addition to pressure-driven flow, radionuclides are transported in both phases by diffusion and dispersion in the porous medium and fractures. The fracture permeability is higher than the permeability of the porous medium such that the most rapid transport mechanism is flow of tritiated gas through fractures. Two retardation mechanisms exist that may significantly reduce the distance and rate of transport: (1) diffusion of tritium gas from the fractures into the matrix, thereby reducing the concentration in the fractures and (2) radioactive decay. The degree to which these retardation mechanisms affect transport will be clear when the interplay among the flow rate through the fractures, matrix diffusion of tritium gas, and radioactive decay are modeled and understood. In addition to tritium, transport of $\mathrm{Kr}-85$ and $\mathrm{C}-14$ will be investigated, assuming the same transport mechanisms that occur for tritium.

The Pictured Cliffs are bounded above and below by low permeability formations. The flow field may be in a transient state, depending on recent gas production history in the area. Initial simulations will focus on axisymmetric flow from a single well with a prescribed pressure; the outer boundary condition is no flow at a prescribed distance yet to be determined. It is expected that temperature gradients have minimal effect on flow and transport.

\subsubsection{Conceptual Model for Contaminant Transport Through the Ojo Alamo}

Pressures measured in the Pictured Cliffs Formation (measurements between 830 and 930 psi [LRL, 1967a], with an estimated maximum pressure of 1,050 psi [Holzer, 1970]) are lower than those in the Ojo Alamo (1,134 psi, based on depth to water of $945 \mathrm{ft}$ [Holzer, 1970]). Thus, if a hydraulic connection exists between the two formations, water should flow downward from the Ojo Alamo to the Gasbuggy cavity. Given this situation, migration of radionuclides from the test cavity to the Ojo Alamo is limited to prompt injection of gaseous radionuclides under pressures created at the time of the explosion. The initial extreme pressures (close to 1 mega bar) are reduced to a few psi within minutes to hours, accompanied by cavity collapse (LLNL, 1999).

Evidence for a connection between the Ojo Alamo and the Gasbuggy cavity includes above-background tritium detected in water from the Ojo Alamo during reentry drilling (LRL, 1968a), continued water flow from the Ojo Alamo into the cavity that caused problems with gas-production testing (Power and Bowman, 1970), and pressure responses in the Ojo Alamo at 
Well EPNG 10-36 coinciding with decreases in chimney pressure during production testing (LRL, 1970). A connection was strongly indicated in the reentry well (Well GB-ER) as a water leak at a depth of approximately $3,550 \mathrm{ft}$ was found in the first section of slots used by the cement staging tool (LRL, 1968a). It could not be determined whether a poor cement bond or motion caused by the test, was the primary fault of the leaks. Posttest investigation of the Ojo Alamo at Well GB-3 further indicated that communication between the aquifer and the reservoir occurred at a single point, although it is impossible to rule out fracture connection (LRL, 1970). Monitoring of wells EPNG 10-36 and GB-3 during production testing found intermittent plugging of the point(s) of communication between the reservoir and aquifer, with complete plugging by late 1969 (Power and Bowman, 1970). The pressure relationship described above between the Ojo Alamo and Pictured Cliffs is borne out by the observation that the chimney contained an unexpected amount of groundwater, with the chemical composition linking its origin to the Ojo Alamo. This water inflow was an undesirable feature, as it reduced the gas production efficiency.

Monitoring of Well EPNG 10-36 by the EPA under the Long-Term Hydrologic Monitoring Program (LTHMP) did not detect radionuclides until low, but above background, tritium concentrations began appearing in 1984 (Figure 5-5). Subsequent logging and sampling by DRI found no tritium at the bottom of the well adjacent to the Ojo Alamo perforations (DRI, 1996b). From 1990 to 1994, Cs-137 was sporadically detected in the LTHMP samples at concentrations up to $16 \mathrm{pCi} / \mathrm{L}$ (EPA, 1992; DOE/NV 1994a and 1995; Boehlecke 2001). No Cs-137 was detected in the sample collected in 1992 or in samples collected since 1994. This inconsistency in the data sets leads to uncertainty as to whether there is contamination in the Ojo Alamo.

During the DRI sampling of the well, low levels of tritium were found much higher in the water column of the well, in a water type uncharacteristic of the Ojo Alamo. As the well is not perforated other than at the Ojo Alamo, the source of this water (and tritium) is unknown. Flowmeter measurements detected no vertical flow in the well that exceeded the detection limit of 0.03 liters per minute. A travel time analysis, using hydraulic data from the site, concluded that migration times in the Ojo Alamo are likely to be too low to support transport for the distance from Well GB-ER to Well EPNG 10-36 over the 17 years observed, supporting the absence of contamination at the screened interval. If contamination were present in the Ojo Alamo, a separate transport analysis 


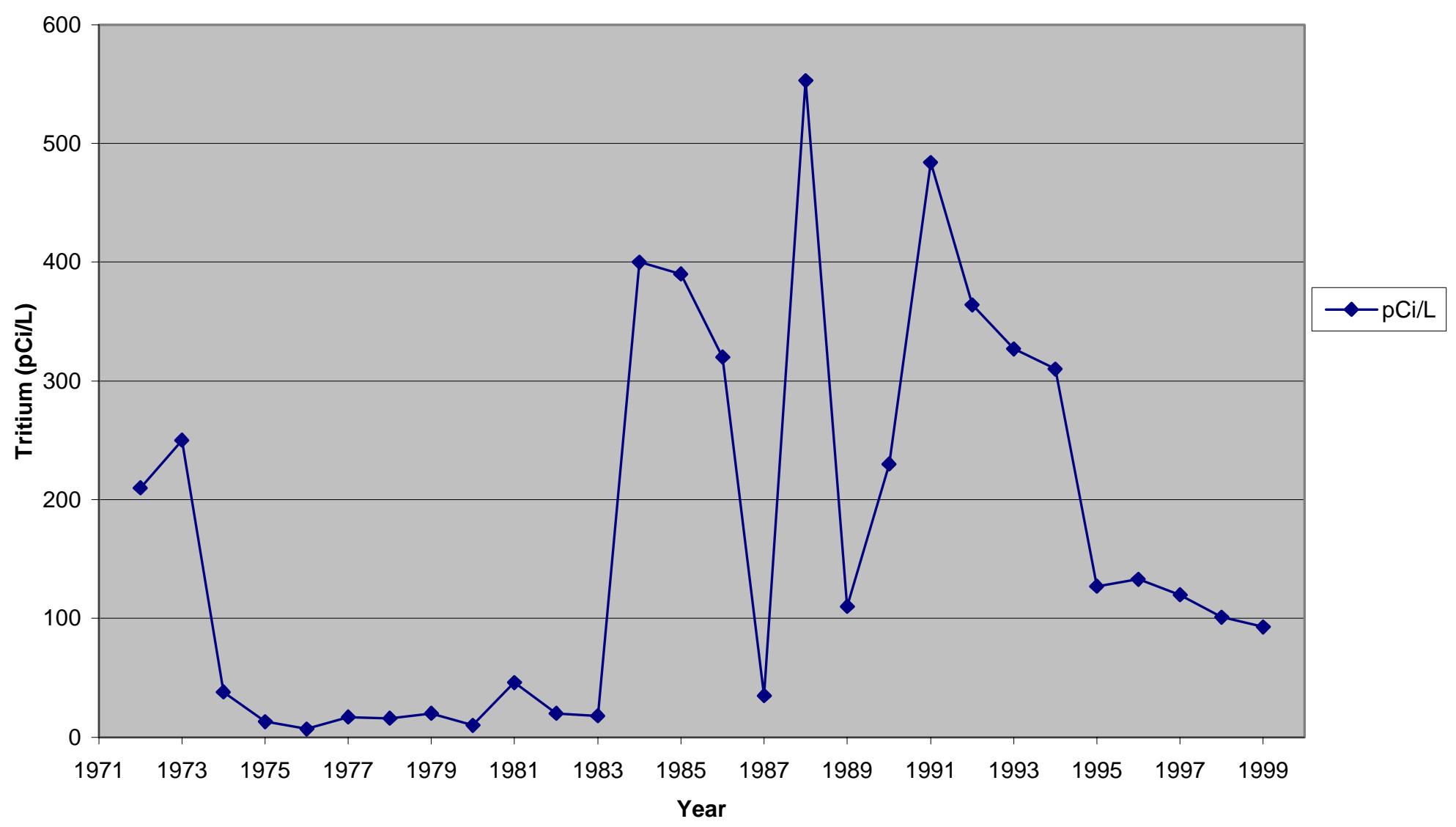

Notes: Data is from Long-Term Hydrologic Monitoring Program operated by the EPA.

The Safe Drinking Water Act standard for tritium in drinking water is 20,000 pCi/L (CFR, 1999).

The original sample collected in June of 1988 was accidentally contaminated. The well was resampled in October of 1988 (Boehlecke, 2001). The results of tritium analysis of the October sample are presented here.

Sources: DOE/NV, 1988, 1993c, 1994a, 1995, and 1996; EPA, 1989a, 1990, 1991, 1992, 1998, 1999a, and 1999b; Boehlecke, 2001.

Figure 5-5

Tritium Concentrations for Well EPNG 10-36 
determined that concentrations of tritium, Sr-90, and Cs-137 are unlikely to be detectable outside the area currently administered by DOE (DRI, 1996a).

Given the data and observations, the Ojo Alamo is not considered a viable contaminant transport pathway. However, uncertainty as to the source of the tritium and Cs-137 detected in Well EPNG 10-36 remains. The field effort will attempt to resolve these uncertainties.

\subsection{Data Quality Objectives of Subsurface Investigations}

The following sections outline the DQOs for the two subsurface investigation tasks.

\subsubsection{Subsurface Modeling DQOs}

The objective of the subsurface modeling for Gasbuggy is to determine the potential for contaminant transport from the Gasbuggy cavity into resources of value, either under existing conditions or during future resource development. If such transport is indicated, it will be determined if the migration poses a potential risk to human health or the environment. This information will be used to identify an appropriate corrective action. Process knowledge, existing data, and analyses are sufficient to determine the absence of risk in the groundwater of the overlying Ojo Alamo sandstone, although evaluation of Well EPNG 10-36 is planned and described below.

The modeling process will:

- Calculate the potential nature and extent of contamination in the subsurface.

- Develop likely scenarios for future resource development and determine their impact on the extent of contamination.

- Evaluate the modeled contaminant extent relative to existing subsurface intrusion (drilling) restrictions.

The following six decision points are identified for the subsurface modeling, with corresponding associated actions:

- If appropriate existing numerical codes cannot be found, or adequate supporting data for the codes do not exist, then implement a different subsurface approach. 
- If current gas production habits from nearby wells cannot be determined with confidence, then make reasonable gas production scenarios with concurrence from NMED.

- If contaminant migration to postulated production wells is predicted, then evaluate the uncertainty level for possible reduction through acceptance of a lower confidence level (e.g., consider going to 50 percent confidence rather than 75 percent confidence) or through additional data collection.

- If contaminant migration to postulated production wells is predicted and uncertainty cannot be effectively reduced, then perform a human health dose assessment for the potential contaminant migration to the projected production wells.

- If the human health dose assessment indicates unacceptable risk, then adjust the existing subsurface exclusion boundary.

- If the results of the contaminant migration model and/or the human health dose assessment indicate the need for a long-term monitoring program, then design a long-term monitoring program consistent with potential hazards.

\subsubsection{Well EPNG 10-36 Data Collection DQOs}

The objective of the data collection activity at Well EPNG 10-36 is to determine if contaminants are entering Well EPNG 10-36 from the Ojo Alamo or if contaminants measured in the well are remnant from some noncontinuing source. The key activity to achieve this objective is the purging of Well EPNG 10-36, which has not occurred prior to previous sampling; however, the removal of the inner tubing string in 1994 did cause the well to recover $100 \mathrm{ft}$. With the only perforations at the bottom (Figure 5-6), the bottom of the well should have contained fresh formation water after the removal. The lack of purging causes uncertainties regarding previous findings, particularly when sampling at discrete depths has identified tritium high in the water column, but not opposite the perforations in the Ojo Alamo. The information gained during this investigation will be used to identify the appropriate corrective action, which is likely to include plugging and abandoning the well.

The objectives of the field activity are:

- Video log the well to determine if the casing integrity has been compromised, thereby allowing water to enter the well at locations in addition to the perforations. 


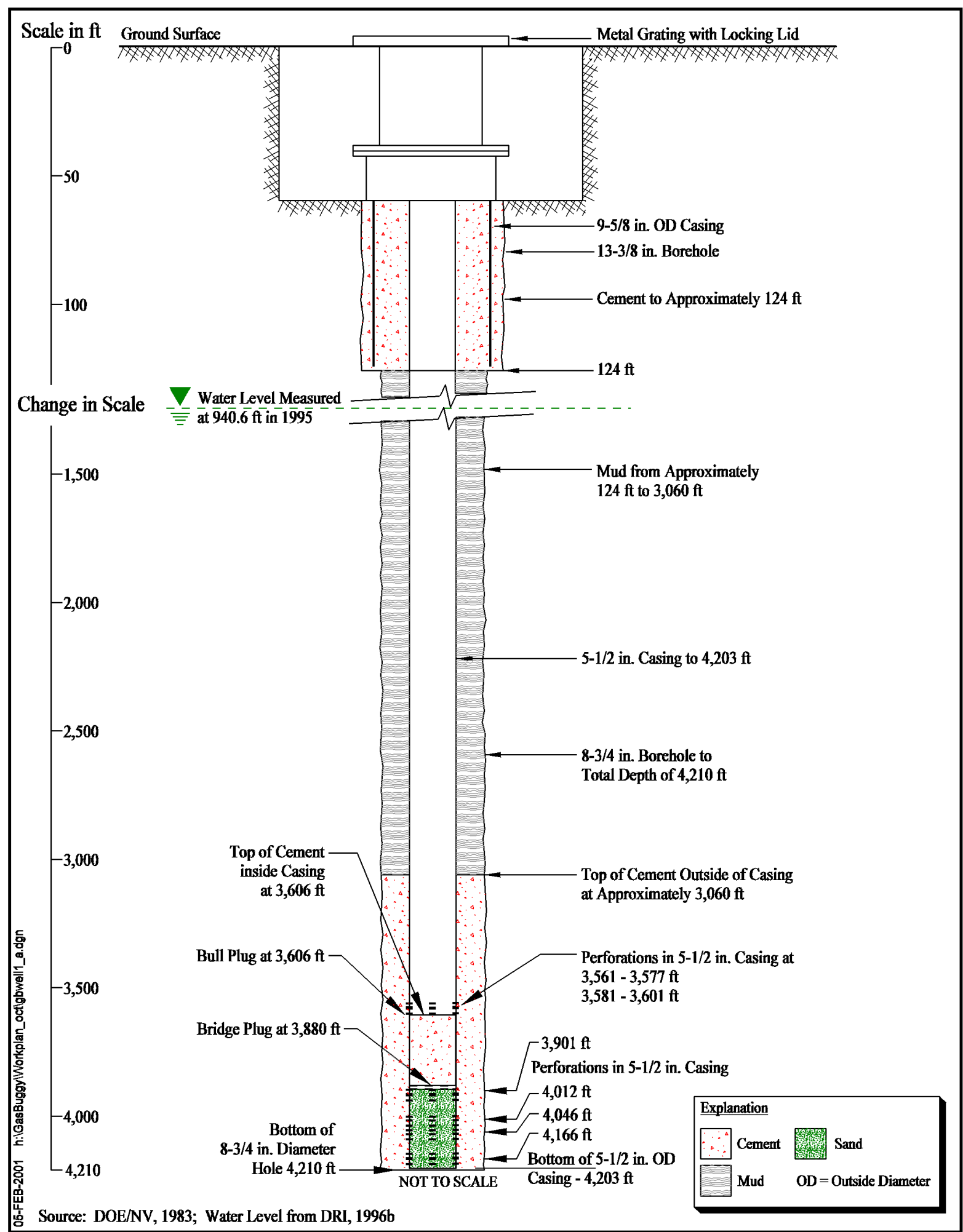

Figure 5-6

Status of Well EPNG 10-36 Prior to 1994 Field Activity 
- Determine if contamination is entering the well from the Ojo Alamo through the perforations at the bottom of the well, or through a breach in the integrity of the casing at another level.

- Collect hydraulic data for the site with a recovery analysis for the Ojo Alamo at Well EPNG 10-36.

The following three decision points are identified for the Well EPNG 10-36 work, with corresponding associated actions:

- If the casing integrity is poor, design a plugging and sealing program appropriate to BLM and State of New Mexico regulations.

- If tritium or Cs-137 at concentrations above background (as measured by EPA sampling prior to 1984) are found entering the well, expand the subsurface modeling activity to include liquid-phase transport from the cavity.

- If the hydraulic conductivity estimated based on testing in Well EPNG 10-36 differs dramatically from estimates in other site wells, expand the subsurface modeling work to include a reanalysis of the Ojo Alamo transport pathway as presented by DRI (1996a), using the new data.

\subsection{Evaluation of Existing Subsurface Data}

The first task is to transform the conceptual flow and transport model described in Section 5.1 into a quantitative model of flow and transport from the Gasbuggy cavity. Literature pertaining to the San Juan Basin will be thoroughly reviewed and both recent and historic data will be gathered from published sources, oil and gas companies, and regulatory agencies. These data are critical to the accurate development of the conceptual model and boundary conditions. The data will be evaluated to determine mean values and ranges for geologic and hydrologic parameters. These data are derived from reservoir production tests, well logging, and laboratory tests of cores. If data important to development of a successful model are unavailable, then data from analogous environments will be used. Data specific to the Gasbuggy cavity and chimney will also be important for defining the subsurface environment. As a joint government-industry test, much of the information about the Gasbuggy test is unclassified, facilitating the analysis. The last step in data collection will be to investigate the history of gas production near the Gasbuggy area and in the Blanco-Dakota gas field.

One likely data gap will be the limited knowledge of the distribution of fracture permeability in the subsurface. In addition, it is unlikely that there is much information regarding the pressure field 
around the well. Another possible data gap will be that the moisture retention curves of fractures are not accurately known. This will limit the accuracy of the pressure versus saturation relationship in fractures, and may result in limited understanding of the relative permeability of fractures under various saturations. Parker et al. (1987) has developed equations for relative permeability between gas and water for porous media, but the parameter values for successful simulation of two-phase flow through fractures will need to be estimated.

Some uncertainty will be introduced in the estimation of retardation due to fracture-matrix interaction (i.e., matrix diffusion). Although the diffusion coefficient for tritium is known, mass flux from a fracture into the matrix is highly dependent upon the tortuosity, which is unknown. Tortuosity can either be estimated from published values for similar rock types, or calculated from core samples using a diffusion cell apparatus and the solutions developed by Moridis (1999), if cores are available.

Regarding the investigation in Well EPNG 10-36, the hydraulic recovery data after purging will be compared to existing estimates of transmissivity to confirm the parameter value used in the previous transport analysis for the Ojo Alamo. Three field measurements of transmissivity have been made in the Ojo Alamo (e.g., in wells GB-1, GB-2, and GB-3 [drilled and tested after the Gasbuggy test]), with resulting values ranging from 0.4 gallons per day per foot (gpd/ft) to $2.3 \mathrm{gpd} / \mathrm{ft}$ (Mercer, 1969). Permeability was also measured on 57 cores collected from the Ojo Alamo in Well GB-1 (LRL, 1967a). These data have a large range with a geometric mean of $1.42 \mathrm{md}$.

\subsection{Identification of Proper Numerical Model}

Flow and transport in the complex subsurface environment of Gasbuggy are coupled processes that must be solved simultaneously to realistically understand the radionuclide distribution. Nearly all petroleum-oriented simulators solve for the flow field only. In contrast, most contaminant-oriented simulators do not solve for gas as an active phase. Few choices exist for the proper simulation of this subsurface environment.

The processes to be simulated include: transient two-dimensional multiphase, multicomponent flow in Cartesian or radial coordinates (possibly three-dimensional flow in Cartesian coordinates); active gas- and liquid-phase flow; radionuclide transport and decay; sources and sinks of mass; and phase changes of water. It is expected that temperature effects will be negligible; however, as work 
proceeds, it may be determined that a nonisothermal flow code is required. The code must be flexible enough to allow for changes to be written in specific pressure-saturation functions, allow implementation of a model for both fracture and matrix flow, allow for matrix diffusion, and allow for changes in the equations of state for gas and water, if necessary.

Two programs exist that will meet these criteria. The Transport of Unsaturated Groundwater Heat (TOUGH2) simulator (LBL, 1999) is a DOE-sponsored code that has been used extensively to study heat and mass flow in geothermal reservoirs, saturated/unsaturated zones, and oil and gas reservoirs. It has been used in studies of both nuclear waste isolation and environmental remediation (LBL, 1995b and 1998). Lawrence Berkeley National Laboratory (1995a) used the TOUGH simulator to study the impact of overpressuring on oil and gas migration in the Uinta Basin, Utah.

The second possible program is the Finite Element Heat and Mass (FEHM) simulator (LANL, 1996) developed at Los Alamos National Laboratory. The simulator models three-dimensional, time-dependent, multiphase, multicomponent, nonisothermal reactive flow through porous and fractured media. However, it appears that only an executable version is available, as opposed to the source code.

\subsection{Modeling Process}

The subsurface flow and transport model will focus around the Gasbuggy cavity at Well GB-ER. Initial simulations will focus on transient radial flow and radionuclide transport around the well. The lateral extent of the boundaries will not be determined until the existing data have been analyzed. The complexity of the domain will be increased by adding production wells and by varying reservoir properties as interpreted from the data. The last step will be to hypothesize pumping scenarios in nearby production gas wells and to apply these rates to the model. This will allow an estimate of radionuclide transport in future pumping scenarios to be developed. The domain will be extended until "far-field" flow and transport effects are diminished. Simulation results will be continually calibrated to pressure and flow data as the model is developed.

The modeling process can be summarized as follows:

1. Evaluate numerical models for the Gasbuggy subsurface application and select appropriate codes. 
2. Locate subsurface data including data from historic sources, current oil and gas development sources, and regulatory agencies.

3. Interpret subsurface data to develop a conceptual model of flow and transport, and select boundary conditions.

4. Evaluate subsurface data to determine mean values and ranges for parameters.

5. Evaluate oil and gas production history in the region to develop a model of stressed conditions.

6. Develop and calibrate a steady-state gas- and liquid-phase flow model of the site.

7. Perform transport calculations under current, nonstressed conditions.

8. Develop a transient model of stressed (development) conditions.

9. Perform transport calculations under stressed conditions.

10. Evaluate results in the context of the subsurface exclusion boundary and with consideration of uncertainty.

11. Determine if long-term monitoring is technically warranted.

\subsection{Well EPNG 10-36 Investigation Plan}

The focus of the Well EPNG 10-36 investigation will be purging and sampling of the well. Experience with the water-level recovery after the production tubing was removed in 1994 indicates that the formation is not very productive and/or the well does not have good communication with the formation (DRI, 1996b). Under these conditions, it is impractical to purge the well using a submersible pump; therefore, purging by bailing is planned. The target will be to remove and recover approximately one well volume prior to sampling. The purged fluid will be managed and disposed of in accordance with Federal and State of New Mexico regulations.

Once purged, the slow recovery will leave the wellbore mostly empty long enough to allow video logging. Video logging will be used to supplement the previous casing integrity logs. Logging in an air-filled well will provide good clarity for the video image, with the added benefit that seepage into the well can also be noted. If poor integrity or leakage is noted, those horizons will be targeted for discrete sampling after well recovery. 
Once the well has recovered to the static water level, discrete water samples will be collected at the perforations and any other zones suspected of providing inflow. Depths where tritium was previously detected will also be sampled. The analytical suite will include tritium; gross alpha; gross beta; Sr-90; gamma spectroscopy (includes Cs-137); major anions and cations; and stable isotopes of hydrogen, oxygen, and carbon. A C-14 and Carbon-13 (C-13) sample will also be collected at the perforations to provide an age for groundwater in the Ojo Alamo as a validation of the slow groundwater velocities previously interpreted.

The Well EPNG 10-36 field activities can be summarized as follows:

1. Measure the static water level in the well.

2. Purge the well bore. It is presumed that recovery will be very slow so the well is purged nearly dry.

3. Video log the well, noting areas of casing weakness and seepage.

4. Monitor water-level recovery to derive hydraulic properties of the formation and determine when recovery is complete.

5. Perform hydrologic logging (e.g., temperature, electrical conductivity, flow logging).

6. Collect water samples. Sample intervals will include the perforations at the Ojo Alamo, horizons where tritium has been detected (i.e., tritium activities greater than $100 \mathrm{pCi} / \mathrm{L}$ in samples collected in 1995 at depths of approximately 950;1,180;1,410; 1,600; and $1,700 \mathrm{ft}$ [DRI, 1996b]), and any suspect zones identified in the video and hydrologic logging.

7. Analyze water samples for tritium, gross alpha, gross beta, Sr-90, gamma spectroscopy (e.g., Cs-137), major anions and cations, and stable isotopes. One sample from the perforations will be analyzed for C-14 and C-13. Samples will also be analyzed for waste characterization parameters, as needed, to dispose of the purge water.

8. Interpret the data and compare to previous investigations and transport analyses for the Ojo Alamo.

9. Determine if the Ojo Alamo should be included as a viable transport pathway from the Gasbuggy cavity.

\subsection{Evaluation of Results}

The results of the numerical simulations will be evaluated to determine the extent of radionuclide migration from the Gasbuggy test. An uncertainty analysis will be conducted so that minimum and 
maximum radionuclide transport distances and times can be estimated with a set degree of confidence. A human health dose assessment will be conducted if migration to a receptor is indicated. The current subsurface intrusion restrictions (drilling exclusion zone) will be reevaluated and possibly altered depending on the results from various stressed (pumping) and nonstressed reservoir conditions, and the results of the dose assessment, if performed.

The results of the Well EPNG 10-36 investigation will be evaluated to determine if the conclusion of minimal transport risk through the Ojo Alamo remains valid and to determine appropriate disposition of Well EPNG 10-36. If results indicate that the Ojo Alamo should be included as a viable transport pathway from the Gasbuggy cavity, groundwater transport will be added to the modeling investigation. 


\subsection{Schedule}

A tentative project schedule has been developed and is presented in Figure 6-1 and Figure 6-2. This schedule provides information regarding the start times and durations for the tasks to be completed as part of the Gasbuggy Site investigation and modeling activities. This schedule also identifies dates for submission of progress reports and other reporting requirements for the Gasbuggy Site investigation project. 


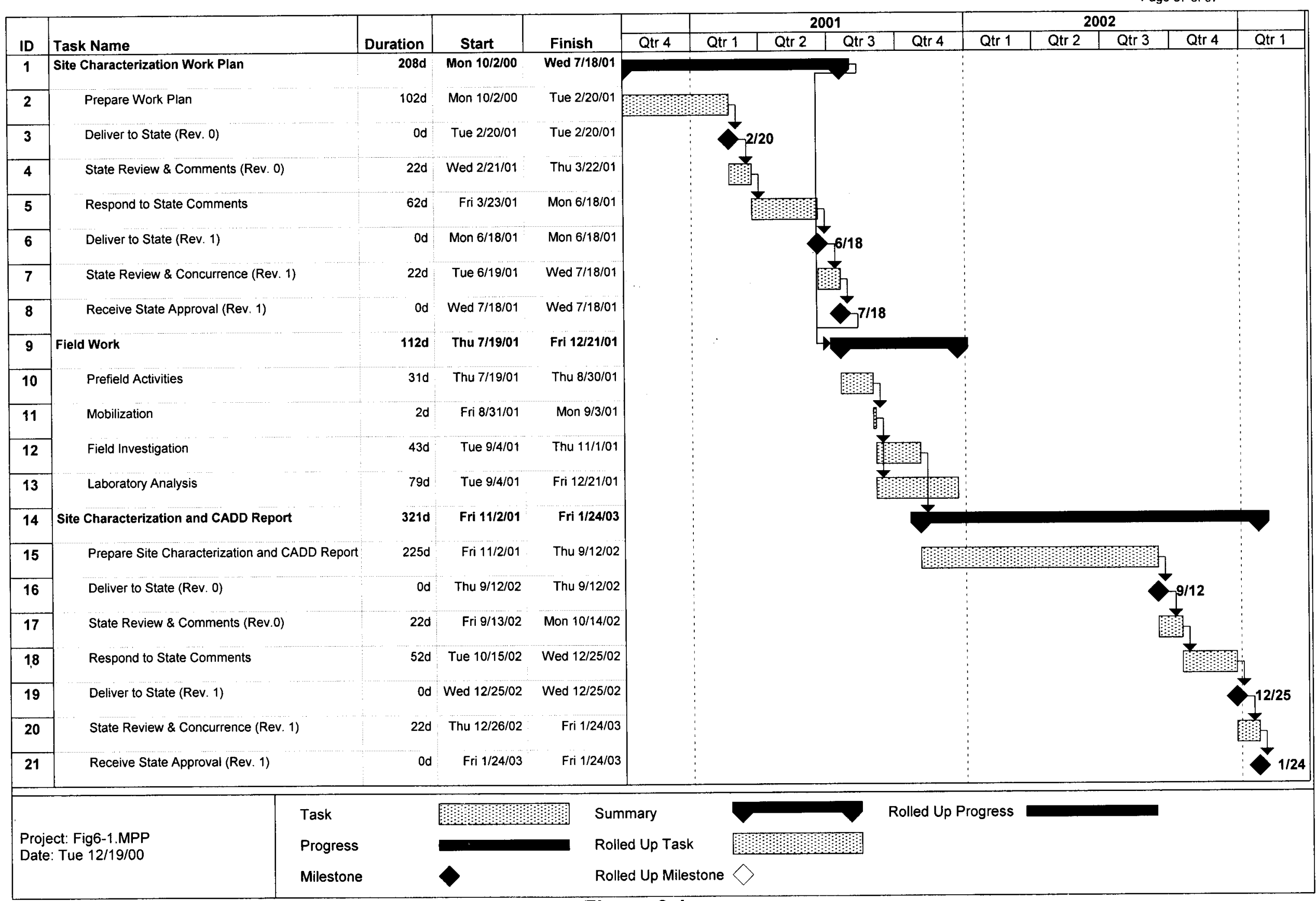




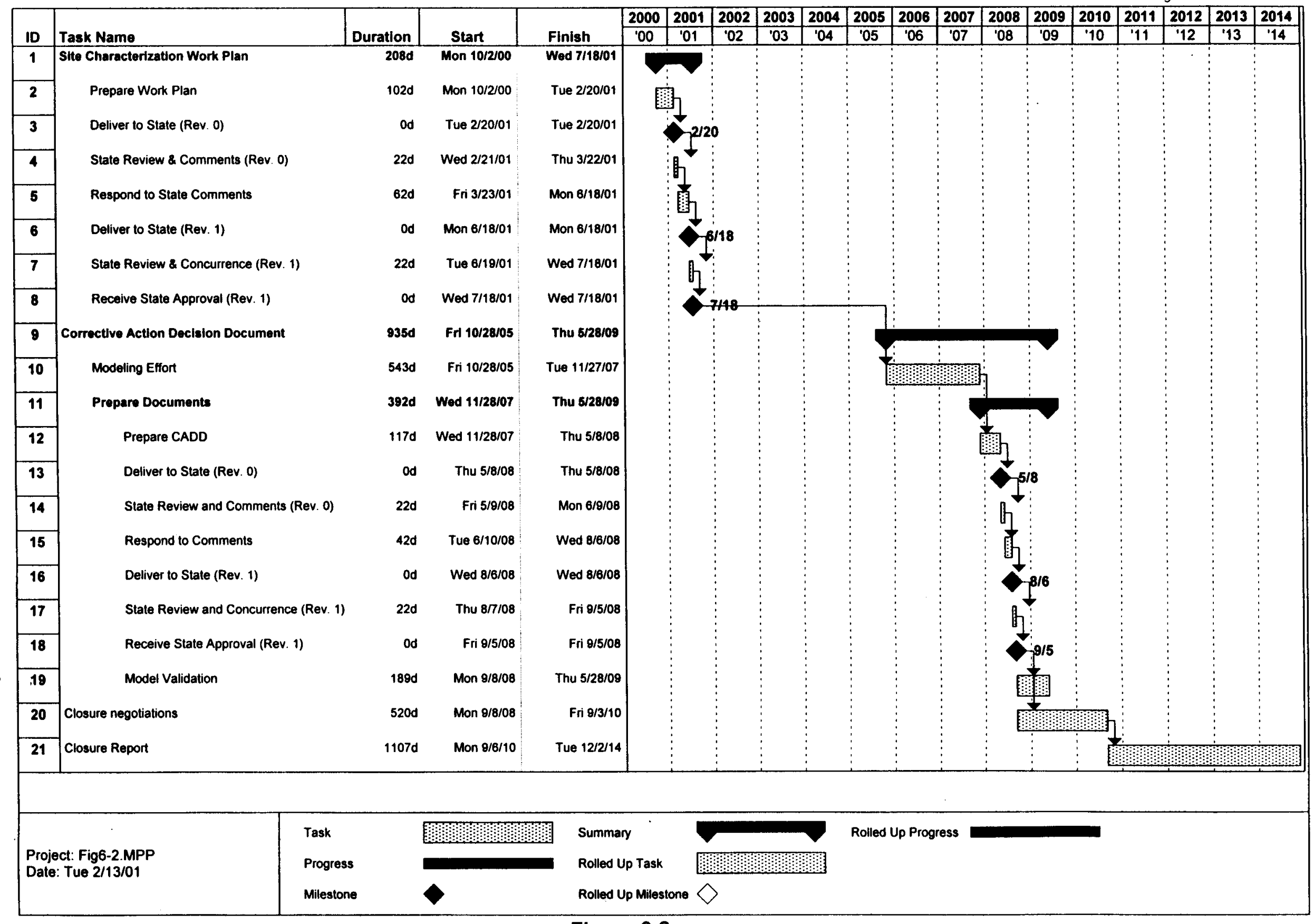




\subsection{References}

AEC, see U.S. Atomic Energy Commission.

Adamson, A.W., and A.P. Gast. 1997. Physical Chemistry of Surfaces, Sixth Edition.

New York, NY: John Wiley \& Sons, Inc.

Atkinson, C.H., and D.C. Ward. 1967. "Project Gasbuggy - Status Report.” In Journal of Petroleum Technology: 1319-1324. Richardson, TX: Society of Petroleum Engineers.

Boehlecke, R.F., SAIC. 2001. Memo to David C. Stahl (IT Corporation), 29 January, entitled Transmittal of U.S. Environmental Protection Agency Data for Well EPNG 10-36 a the Gasbuggy Site. Las Vegas, NV.

CFR, see Code of Federal Regulations.

Code of Federal Regulations. 1999a. Title 40 Part 261, "Identification and Listing of Hazardous Waste." Washington, DC: U.S. Government Printing Office.

Code of Federal Regulations. 1999b. Title 40 Part 141.16, "Maximum Contaminant Levels for Beta Particle and Photon Radioactivity from Man-Made Radionuclides in Community Water Systems." Washington, DC: U.S. Government Printing Office.

Desert Research Institute. 1996a. Assessment of Hydrologic Transport of Radionuclides from the Gasbuggy Underground Nuclear Test Site, New Mexico, Publication No. 45148, DOE/NV/11508-16. Prepared by S. Earman, J. Chapman, and R. Andricevic. Reno, NV: Water Resources Center.

Desert Research Institute. 1996b. Tritium Migration at the Gasbuggy Site: Evaluation of Possible Hydrologic Pathways, Publication No. 45144, DOE/NV/11508-12. Prepared by J. Chapman, T. Mihevc, and B. Lyles. Reno, NV: Water Resources Center.

DHEW, see U.S. Department of Health, Education, and Welfare.

DOE/NV, see U.S. Department of Energy, Nevada Operations Office.

DRI, see Desert Research Institute.

Eberline Instrument Corporation. 1971. On-Site Radiological Safety During Production Testing January 25, 1968 to December 31, 1969, PNE-1006. Sante Fe, NM.

Eberline Instrument Corporation. 1979. Project Gasbuggy Radiation Contamination Clearance Report, PNE-G-89. Sante Fe, NM. 
EG\&G EM, see EG\&G Energy Measurements.

EG\&G Energy Measurements. 1994. Aerial Photograph of Gasbuggy Site, EG\&G 7992-57. Nellis Air Force Base, NV: Remote Sensing Laboratory Photo Library.

EG\&G Energy Measurements. 1995. An Aerial Radiological Survey of Project Gasbuggy and Surrounding Area, Rio Arriba County, NM, Date of Survey October 27, 1994, EGG 11265-1129. Las Vegas, NV.

EIC, see Eberline Instrument Corporation.

El Paso Natural Gas Company, U.S. Atomic Energy Commission, U.S. Bureau of Mines, and Lawrence Radiation Laboratory. Project Gasbuggy: A Feasibility Study. 1965. Prepared by H. Gevertz, R.F. Lemon and W.T. Hollis (EPNG); M.A. Lekas (AEC); D.C. Ward, and C.H. Atkinson (USBM); and Dr. N Bonner (LRL). El Paso, TX.

EPA, see U.S. Environmental Protection Agency.

EPNG, see El Paso Natural Gas Company.

F\&S, see Fenix \& Scisson, Inc.

Fenix \& Scission, Inc. 1968. Hole History Data, GB-E.

Holmes \& Narver, Inc. 1967a. "Project Gasbuggy Control Point Site Plan,” R-094-C5.1. Las Vegas, NV.

Holmes \& Narver, Inc. 1967b. “Project Gasbuggy Recording Trailer Park Site Plan,” R-094-C4.1. Las Vegas, NV.

Holmes \& Narver, Inc. 1967c. "Project Gasbuggy Surface Ground Zero Site Plan,” R-094-C3.1. Las Vegas, NV.

Holzer, A. 1970. "Gasbuggy in Perspective." In Proceedings of the American Nuclear Society Symposium of Engineering with Nuclear Explosives: 662-697, CONF-700101, Vol. 1. Washington, DC: American Nuclear Society.

Koopman, F.C., and W.C. Ballance. 1968a. Hydrologic Tests in Hole GB-1, Project Gasbuggy, Rio Arriba County, New Mexico, USGS-OFR, PNE-G-26. Denver, CO: U.S. Geological Survey.

Koopman, F.C., and W.C. Ballance. 1968b. Hydrologic Tests in Hole GB-2, Project Gasbuggy, Rio Arriba County, New Mexico, USGS-OFR, PNE-G-27. Denver, CO: U.S. Geological Survey.

LANL, see Los Alamos National Laboratory. 
Lawrence Berkeley National Laboratory. 1995a. "Analysis of Over-Pressure Mechanisms in the Uinta Basin, Utah." In Proceedings of the TOUGH Workshop '95, LBL-37200, CONF-9503110: 157-162. Prepared by B. McPherson and J. Bredehoeft. Berkeley, CA.

Lawrence Berkeley National Laboratory. 1995b. Proceedings of the TOUGH Workshop 1995, LBL-37200, CONF-9503110. Edited by K. Pruess. Berkeley, CA.

Lawrence Berkeley National Laboratory. 1998. Proceedings of the TOUGH Workshop 1998, LBL-41995, CONF-9503110. Edited by K. Pruess. Berkeley CA.

Lawrence Berkeley National Laboratory. 1999. TOUGH2 User's Guide, Version 2.0, LBL-43134. Prepared by K. Pruess. Berkeley, CA.

Lawrence Livermore National Laboratory. 1976. Information Pertinent to the Migration of Radionuclides in Ground Water at the Nevada Test Site, Part 1: Review and Analysis of Existing Information, UCRL-52078, Pt. 1. Prepared by I.V. Borg, R. Stone, H.B. Levy, and L.D. Ramspott. Livermore, CA.

Lawrence Livermore National Laboratory. 1995. Uncertainties Associated with the Definition of a Hydrologic Source Term for the Nevada Test Site, UCRL-ID-120322. Prepared by D. K. Smith, B.K. Esser, and J.L. Thompson. Livermore, CA.

Lawrence Livermore National Laboratory. 1999. Evaluation of the Hydrologic Source Term from Underground Nuclear Tests in Frenchman Flat at the Nevada Test Site: The Cambric Test, UCRL-ID-132300. Edited by F.B. Thompson, C.J. Bruton, and G.A. Pawloski. Livermore, CA.

Lawrence Radiation Laboratory. 1967a. Acceptability of the Gasbuggy Site, UCID-15132. Prepared by D.E. Rawson and J.A. Korver. Livermore, CA.

Lawrence Radiation Laboratory. 1967b. Photographs of Gasbuggy Site: AEC-67-8175. Copies of photographs are available in the ITLV Technical Information Center. Livermore, CA.

Lawrence Radiation Laboratory. 1968a. Gasbuggy Postshot Investigations in GB-ER, UCRL-50425. Prepared by J.A. Korver and D.E. Rawson. Livermore, CA.

Lawrence Radiation Laboratory. 1968b. Gasbuggy Preliminary Postshot Summary Report, UCRL-50386. Prepared by F. Holzer. Livermore, CA.

Lawrence Radiation Laboratory. 1970. Gasbuggy Postshot Hydrologic Investigations in GB-3, PNE-G-62, UCRL-50812. Prepared by J.A. Korver. Livermore, CA.

LBL, see Lawrence Berkeley National Laboratory.

LLNL, see Lawrence Livermore National Laboratory. 
Los Alamos National Laboratory. 1996. Users Manual for the FEHMN Application,

LA-UR-94-3788: 127. Prepared by G.A. Zyvoloski, B.A. Robinson, Z.V. Dash, and L.L. Trease. Los Alamos, NM.

LRL, see Lawrence Radiation Laboratory.

Mercer, J.W. 1967. Geology and Hydrology of Project Gasbuggy Site, Rio Arriba County, New Mexico, USGS Technical Letter: Gasbuggy-4. Denver, CO: U.S. Geological Survey.

Mercer, J.W. 1968. Inventory of Wells and Springs Within a 10-Mile Radius of Project Gasbuggy, Rio Arriba County, New Mexico, USGS-OFR, PNE-G-25. Denver, CO: U.S. Geological Survey.

Mercer, J.W. 1969. Hydrology of Project Gasbuggy Site, Rio Arriba County, New Mexico, PNE-1013. Denver, CO: U.S. Geological Survey.

Moridis, G.J. 1999. "Semianalytical Solutions for Parameter Estimation in Diffusion Cell Experiments." In Water Resources Research, V 35(6): 1729-1740. Washington DC: American Geophysical Union.

New Mexico Administrative Code. 1996a. Title 20 NMAC 6.2, Ground and Surface Water Protection. Santa Fe, NM.

New Mexico Administrative Code. 1996b. Title 19 NMAC 15 Part C, 105, Pit for Clay, Shale, Drill Fluid and Drill Cuttings. Santa Fe, NM.

New Mexico Administrative Code. 1997. Title 20 NMAC 7 Part 3, 410, Abandoned Sewers and On-Site Liquid Waste Systems. Santa Fe, NM.

New Mexico Bureau of Mines and Mineral Resources. 1983. Hydrogeology and Water Resources of San Juan Basin, New Mexico, Hydrologic Report 6. Prepared by W.J. Stone, F.P. Lyford, P.F. Frenzel, N.H. Mizell, and E.T. Padgett. Sante Fe, NM.

New Mexico Environment Department. 2000a. Application of Inorganic Background Values in the Risk Assessment Process, Position Paper. Santa Fe, NM: Hazardous and Radioactive Materials Bureau.

New Mexico Environment Department. 2000b. Use of Total Petroleum Hydrocarbon (TPH) Test Results for Site Characterization, Position Paper. Santa Fe, NM: Hazardous Waste Bureau.

NMAC, see New Mexico Administrative Code.

NMED, see New Mexico Environmental Department. 
Parker, J.C., R.J. Lenhard, and T. Kuppusamy. 1987. "A Parametric Model for Constitutive Properties Governing Multiphase Flow in Porous Media." In Water Resources Research, V23 (4): 618-624.

Peterson, J.A., A.J. Loleit, C.W. Spencer, and R.A. Ullrich. 1965. "Sedimentary History and Economic Geology of San Juan Basin." In Bulletin of the American Association of Petroleum Geologists, V.49(11): 2076-2119. Tulsa, OK.

Power, D.V., and C.R. Bowman. 1970. "An Evaluation of Water Production from the Gasbuggy Reentry Well." In Proceedings, American Nuclear Society Symposium on Engineering with Nuclear Explosives, PNE-G-58, Conf. 700101-11. La Grange Park, IL: American Nuclear Society.

REECo, see Reynolds Electrical \& Engineering Co., Inc.

Reynolds Electrical \& Engineering Co., Inc. 1986. Hazardous Waste Installation Assessment Report, DOE/NV/10327-23. Prepared by D.N. Fauver. Las Vegas, NV.

SAIC, see Science Application International Corporation.

Science Application International Corporation. 2000. Third Quarter 2000 Surface Geophysical Survey Report Gasbuggy Site Dulce, New Mexico. Prepared by J. Warren. Harrisburg, PA.

Smith, C.F., and F.F. Momyer. 1969. "Studies of Chemical and Radiochemical Composition of Natural Gas from the Cavity Produced by the Project Gasbuggy Nuclear Shot." In Radiological Health Data and Reports, 10(7): 281-288. Washington, DC: U.S. Department of Health, Education, and Welfare.

Sokol, D. 1970. Ground Water Safety Evaluation - Project Gasbuggy, PNE-1009. Palo Alto, CA: Teledyne Isotopes.

Stosur, J.J. 1977. "Current Status of Projects Gasbuggy, Rulison, and Rio Blanco and an Appraisal of Nuclear-Explosive Fracturing Potential for the Near Future." In The Future Supply of Nature-Made Petroleum and Gas; Technical Reports: 697-721. Edited by R.F. Meyer. New York, NY: Pergamon Press.

Unknown DOE Contractor. 1967. Photographs of the Gasbuggy Site taken by unknown DOE contractor. Copies of photographs are available in the ITLV Technical Information Center. Las Vegas, NV.

U.S. Atomic Energy Commission. 1971. Project Gasbuggy Manager's Report, PNE-G-79, NVO-37. Las Vegas, NV.

U.S. Atomic Energy Commission. 1973. Planning and Operations Directive, Gasbuggy, 1973 Production Testing Program, NVO-137. Las Vegas, NV. 
U.S. Department of Energy, Nevada Operations Office. 1978. Project Gasbuggy Well Plugging and Site Restoration Plan, NVO-195. Las Vegas, NV.

U.S. Department of Energy, Nevada Operations Office. 1983. Project Gasbuggy Site Restoration Final Report, PNE-G-90, NVO-211. Prepared by Holmes \& Narver, Inc. Las Vegas, NV.

U.S. Department of Energy, Nevada Operations Office. 1986. Long-Term Hydrologic Monitoring Program, Project Gasbuggy, Rio Arriba County, New Mexico, NVO-277. Las Vegas, NV.

U.S. Department of Energy, Nevada Operations Office. 1988. CERCLA Preliminary Assessment of DOE's Nevada Operations Office Nuclear Weapons Testing Areas. Prepared by Desert Research Institute. Las Vegas, NV.

U.S. Department of Energy, Nevada Operations Office. 1993a. A Class III Cultural Resources Survey of the U.S. Department of Energy Gasbuggy Stimulation Test Site, Rio Arriba County, New Mexico, DOE/NV/10972--66. Prepared by IT Corporation and Mariah Associates. Las Vegas, NV.

U.S. Department of Energy, Nevada Operations Office. 1993b. Floodplains and Wetlands Survey Results for the Gasbuggy and Gnome-Coach Sites, New Mexico, DOE/NV/10972--58. Prepared by IT Corporation. Las Vegas, NV.

U.S. Department of Energy, Nevada Operations Office. 1993c. Nevada Test Site Annual Site Environmental Report - 1992, DOE/NV/10630-66, Vol. 1, UC-600. Reynolds Electrical \& Engineering Co., Inc. Las Vegas, NV.

U.S. Department of Energy, Nevada Operations Office. 1993d. Sensitive Species Survey Results for the Gasbuggy and Gnome-Coach Sites, New Mexico, DOE/NV/10972--54. Prepared by IT Corporation. Las Vegas, NV.

U.S. Department of Energy, Nevada Operations Office. 1993e. Survey Plans for DOE/NV Sites Outside of Nevada, DOE/NV/10972--27. Prepared by IT Corporation. Las Vegas, NV.

U.S. Department of Energy, Nevada Operations Office. 1994a. Nevada Test Site Annual Site Environmental Report - 1993, DOE/NV/11432-123, Vol. 1, UC-600. Las Vegas, NV.

U.S. Department of Energy, Nevada Operations Office. 1994b. United States Nuclear Tests, July 1945 through September 1992, Rev. 14, DOE/NV-209. Las Vegas, NV.

U.S. Department of Energy, Nevada Operations Office. 1995. Nevada Test Site Annual Site Environmental Report - 1994, DOE/NV/11432-175, UC-600. Reynolds Electrical \& Engineering Co., Inc. Las Vegas, NV. 
U.S. Department of Energy, Nevada Operations Office. 1996. Nevada Test Site Annual Site Environmental Report for Calendar Year 1995, DOE/NV/11718-037. Prepared by Bechtel Nevada. Las Vegas, NV.

U. S. Department of Health, Education, and Welfare, Southwestern Radiological Health Laboratory. 1970. Report of Off-Site Surveillance for Project Gasbuggy March 1967 to June 1968, SWRHL-99R. Las Vegas, NV.

U.S. Environmental Protection Agency. 1973. Results of Sampling Natural Gas Wells in the Vicinity of Project Gasbuggy, NERC-LV-539-9. Las Vegas, NV.

U.S. Environmental Protection Agency. 1974. Final Report of the Radiological Surveillance Program for the Project Gasbuggy Production Test May 15, 1973 to November 6, 1973, NERC-LV-539-30. Las Vegas, NV.

U.S. Environmental Protection Agency. 1989a. Offsite Environmental Monitoring Report: Radiation Monitoring Around United States Nuclear Test Areas, Calendar Year 1988, EPA/600/4-89/019, DOE/DP/00539-061. Las Vegas, NV.

U.S. Environmental Protection Agency. 1989b. Soil Sampling Quality Assurance User's Guide, Second Edition, EPA/600/8-89/046. Prepared by D.S. Barth, B.J. Mason, T.H. Starks, and K.W. Brown. Las Vegas, NV.

U.S. Environmental Protection Agency. 1990. Offsite Environmental Monitoring Report: Radiation Monitoring Around United States Nuclear Test Areas, Calendar Year 1989, EPA 600/4-90/016, DOE/DP00539-062. Las Vegas, NV.

U.S. Environmental Protection Agency. 1991. Offsite Environmental Monitoring Report: Radiation Monitoring Around United States Nuclear Test Areas, Calendar Year 1990, EPA 600/4-91/030, DOE/DP00539-063. Las Vegas, NV.

U.S. Environmental Protection Agency. 1992. Offsite Environmental Monitoring Report: Radiation Monitoring Around United States Nuclear Test Areas, Calendar Year 1991, EPA 600/R-93/141. Las Vegas, NV.

U.S. Environmental Protection Agency. 1994a. Guidance for the Data Quality Objective Process, EPA AQ/G-4. Washington, DC.

U.S. Environmental Protection Agency. 1994b. USEPA Contract Laboratory Program National Functional Guidelines for Inorganic Data Review, EPA-540/R-94/013. Washington, DC.

U.S. Environmental Protection Agency. 1995. Surface Radioactivity at the Plowshare Gas-Stimulation Test Sites: Gasbuggy, Rulison, Rio Blanco, EPA 600/R-95/002. Prepared by S.H. Faller. Washington, DC. 
U.S. Environmental Protection Agency. 1996. Test Methods for Evaluating Solid Waste, Physical/Chemical Methods, SW-846, CD Rom PB97-5019286GEI (CD Rom contains updates for 1986, 1992, 1994 and 1996). Washington, DC.

U.S. Environmental Protection Agency. 1997. Annual Water Sampling and Analysis Calendar Year 1996, EPA-402-R-97-010. Prepared by M.Davis. Las Vegas, NV.

U.S. Environmental Protection Agency. 1998. Annual Water Sampling and Analysis Calendar Year 1997, Rulison Test Site Area, Rio Blanco Test Site Area, Faultless Test Site Area, Shoal Test Site Area, Gasbuggy Test Site Area, Gnome Test Site Area, EPA-402-R-98-005. Las Vegas, NV.

U.S. Environmental Protection Agency. 1999a. Annual Water Sampling and Analysis Calendar Year 1998, Rulison Test Site Area, Rio Blanco Test Site Area, Faultless Test Site Area, Shoal Test Site Area, Gasbuggy Test Site Area, Gnome Test Site Area, EPA-402-R-98-014. Las Vegas, NV.

U.S. Environmental Protection Agency. 1999b. Annual Water Sampling and Analysis Calendar Year 1999, Rulison Test Site Area, Rio Blanco Test Site Area, Faultless Test Site Area, Shoal Test Site Area, Gasbuggy Test Site Area, Gnome Test Site Area, EPA-402-R-99-012. Las Vegas, NV.

U.S. Environmental Protection Agency. 1999c. Region IX Preliminary Remediation Goals (PRGs) 1999. Prepared by S.J. Smucker. San Francisco, CA.

U.S. Environmental Protection Agency. 1999d. USEPA Contract Laboratory Program National Functional Guidelines for Organic Data Review, EPA 540/R-99/008. Washington, DC.

USGS, see U.S. Geological Survey.

U.S. Geological Survey. 1995. "Rock School Quadrangle, Colorado - Rio Blanco County," 7.5-Minute Series (Topographic). Denver, CO.

Wang, J.S.Y., and T.N. Narasimhan. 1985. "Hydrologic Mechanisms Governing Fluid Flow in a Partially Saturated, Fractured, Porous Medium." In Water Resources Research, V.21: 1861-1874. Washington, DC: American Geophysical Union.

Ward, D.C., C.H. Atkinson, and J.W. Watkins. 1966. "Project Gasbuggy - A Nuclear Fracturing Experiment.” In Journal of Petroleum Technology: 139-145. Richardson, TX: Society of Petroleum Engineers.

Weir, Jr., J.E. 1971. Hydraulic Testing of the Ojo Alamo Sandstone in Hole GB-3, Project Gasbuggy, Rio Arriba County, New Mexico, USGS-OFR, USGS-474-91. Denver, CO: U.S. Geological Survey. 
Wofford, S., Lawrence Livermore National Laboratory. 2000a. Letter to D. Arnold (Science Applications International Corporation) transmitting 25 photographs of the Gasbuggy Site, 5 June. Copies of photographs are available in the ITLV Technical Information Center. Livermore, CA: Laboratory Archives.

Wofford, S., Lawrence Livermore National Laboratory. 2000b. Letter to J. Simms (IT Corporation) transmitting 16 photographs of the Gasbuggy Site, 7 March. Copies of photographs are available in the ITLV Technical Information Center. Livermore, CA: Laboratory Archives.

Wycoff, R.F., U.S. Department of Energy, Nevada Operations Office. 2000. Letter to James P. Bearzi (NMED), 30 August, entitled Highlights of August 2-3, 2000, Meeting. Las Vegas, NV. 
Appendix A

Gasbuggy Historical Radiological Monitoring and Sampling Results 


\section{A.1.0 Summary of Radiological Monitoring and Sampling for the Gasbuggy Site Surface}

A review of the historical radiological environmental monitoring data for the Gasbuggy Site was performed to help determine if additional radiological characterization will be required. The information in this appendix does not include information on all monitoring and sampling efforts conducted in support of Project Gasbuggy, but those data that provide information which may be used to help determine current site surface and shallow subsurface conditions. For simplicity, shallow subsurface is defined as the area in which there is a potential for contamination associated with surface activities (e.g., gas flaring). A discussion of the historical data to be used in the subsurface (e.g., contamination from the cavity) investigation effort is included in Section 5.0 of the Work Plan. Therefore, it is not included in this appendix.

The review consisted of an evaluation of the historical data associated with radiological monitoring of the SGZ area during and after the detonation, natural gas discharges to the flare stack, wastes, air samples, gas samples, soil moisture sampling, vegetation sampling, thermoluminescent dosimeter measurements, remote area monitoring system, and aerial radiological surveys. It was concluded from this review of historical reports that:

- The level of radionuclide contamination in the soil that resulted from atmospheric releases from the flare stack were minimal.

- No radionuclides other than tritium and naturally occurring radioisotopes were found in soil samples collected during the 1978 Gasbuggy restoration effort (EIC, 1979).

- No soil moisture samples collected during the 1978 sampling event exceeded the site clearance criteria of 30,000 picocuries per milliliter $(\mathrm{pCi} / \mathrm{mL})$ of soil moisture (EIC, 1979).

- The highest concentration of tritium in soil moisture $(1,303 \mathrm{pCi} / \mathrm{mL})$ was at a location near the flare stack at a depth of $4 \mathrm{ft}$ below ground surface (EIC, 1979).

- No radioactive material or low-level radioactive waste was buried on site during the 1978 restoration except for tritium contaminated water which was injected into the emplacement well and detonation cavity (EIC, 1979).

- The results from thermoluminescent dosimeter (TLD) radiation measurements were within the range that would be encountered from natural background radiation (AEC, 1973). 
- Aerial surveys conducted during the detonation and after site restoration (1994) indicated that the range of exposure rates measured were within the range expected for natural background. No evidence of Cs-137 or any other man-made radionuclides were found (AEC, 1973 and EG\&G/EM, 1995). 


\section{A.2.0 Monitoring and Sampling During Detonation and Posttest Drilling}

Extensive monitoring and sampling was conducted during the detonation and subsequent posttest drilling. The information presented in this section includes information and data which supports the conclusion that no dynamic venting occurred during the detonation; therefore, the only radionuclides of concern at the Gasbuggy Site are the result of gas-flaring operations.

\section{A.2.1 Detonation and Containment}

Although the stemming plan was designed to seal the emplacement well and prevent any leakage from the test, a small amount of radioactivity was detected at ground surface about eight hours after the detonation. The leakage apparently occurred in the explosive arming and firing cable with breaks in that cable possibly allowing radioactive gas to leak to porous portions of the stemmed emplacement hole (LRL, 1968a). After 1/1/2 hours, all cables were cut and sealed at the wellhead. It is estimated that about one curie of gaseous radioactivity had escaped to the atmosphere (LRL, 1968b). Analysis of a sample of the gas leaking up the cables determined the only radioactive materials present were inert noble gases (i.e., krypton and xenon) (AEC, 1971).

\section{A.2.2 Thermoluminescent Dosimeters}

The U.S. Bureau of Radiological Health (Southwestern Radiological Health Laboratory) provided off-site radiological safety support to the Gasbuggy Project in June 1967. As a part of an interagency agreement with the AEC, a network of TLDs was established around the site out to approximately eight miles. Approximately 50 TLDs were located at approximately 11/2-mile intervals along the existing roads and highways. The TLDs were posted on October 17, 1967, and exchanged on November 15, 1967, to measure background radiation prior to the experiment. They were exchanged again on December 8, 1967, two days before the detonation and removed on January 15, 1968, following the drill back into the test cavity. This set of TLDs were to measure radiation levels following the detonation and during drill-back activities (DHEW, 1970).

Readout of the predetonation TLDs (posted 11/15/1967 - 12/08/1967) showed dose rates ranging from 0.25 to 0.50 milliRoentgen (mR) per day. The post detonation TLD sets (posted 12/08/1967 - 
1/15/1968) read from 0.29 to $0.55 \mathrm{mR}$ per day (DHEW, 1970). The mean plus or minus one standard deviation for the pre- and postdetonation TLD sets were $0.37 \pm 0.47$ and $0.37 \pm 0.55 \mathrm{mR}$ per day, respectively. The results for the two sets of TLDs were within the range of naturally occurring background levels, and showed no statistically significant difference between pre- and postdetonation periods.

\section{A.2.3 Remote Area Monitoring System}

Remote area monitoring system (RAMS) detectors were installed in the emplacement well (Well GB-E), at the wellhead and on 250-ft and 450-ft arcs around the emplacement well, during the detonation. The RAMS detectors positioned down-hole and at the wellhead registered minimal readings due to radioactive gas migrating up the hole in the hours immediately after detonation. The maximum reading at the wellhead was $160 \mathrm{mR}$ per hour, approximately 11 hours after detonation. None of the RAMs stations on the 250-ft and 450-ft arcs positioned around the wellhead indicated any radiation levels above background. No RAMS readings above background were observed during posttest operations, except in response to radioactive sources used during well-logging (AEC, 1973).

\section{A.2.4 Air Samples}

Twenty-four hour air samples were collected daily from December 10, 1967, until after the drill-back and gas sampling operations were completed, and the wellhead was shut in on January 17, 1968. Air samples indicated that "airborne radioactivity around SGZ never varied significantly from normal background levels" (AEC 1971).

\section{A.2.5 Gas Sampling}

During posttest drilling, gas samples were collected directly from the wellhead, the high pressure containment system, the cellar under the drill rig, and from the bottom of the reentry hole (Well GB-ER). None of the gas samples collected during posttest drilling contained radioactive material except for the noble gases xenon and krypton (AEC, 1971). 


\section{A.2.6 Aerial Surveys}

Aerial radiation measurements were performed by the U.S. Public Health Service's (PHS) South Western Radiological Health Laboratory on December 10, 1967, during the Gasbuggy detonation. A U.S. Air Force C-47 equipped for tracking radioactive plumes was flown at 11,000 ft. A PHS Turbo-Beech, Vegas 8, was used for low altitude monitoring (7,700-8,700 ft) of SGZ and was equipped for sampling and tracking any released activity. All readings made by both aircraft during the mission were at background levels (DHEW, 1970). 


\section{A.3.0 Effluent Monitoring During Gas Production Testing}

Six major production tests were conducted after reentry drilling was completed in January 1968. Two took place in 1968, three in 1969, and the last one in 1973. Long-term production testing was completed in November 1973 and pressure monitoring activities were completed in late 1976 (DOE/NV, 1978). During production testing, water was carried up the tubing with the gas in the reentry well when the velocity of gas was sufficient to carry up water (AEC, 1971).

The limited tests in June and July 1968 produced 1,440 gallons of water. This water was placed in 36 55-gallon drums, "gelled," and sent to the NTS for disposal. The subsequent tests produced too much water to drum and dispose of in this fashion. Therefore, a steam/spray system was designed to vaporize the water into the flame at the top of the flare stack (AEC, 1971).

Tritium and $\mathrm{Kr}-85$ were the primary radionuclides detected in the gas and liquid samples that were collected during production tests. A system to analyze low levels of krypton and tritium (STALLKAT) was utilized during all production test through November of 1969 (AEC, 1971).

During the 1973 gas production tests, the literature indicates that "The EPNG on-line monitoring trailer was used to maintain a continuous record of radioactivity produced and flared. A Liquid Scintillation Spectrometer was used to measure radioactivity concentrations in water sampled daily (AEC, 1973)."

Calculations for the total tritium released during the June and July 1968 tests was based on analysis of gas and moisture samples collected and analyzed by LRL. The tritium released during the tests was composed of three parts: tritium in the gas monitored by the STALLKAT system, tritium in wastewater from the steam spray operations, and freeze-out samples collected after the bulk liquid separation. The data show 2,432 curies of tritium were released to the environment through November of 1969. The Kr-85 released during the June and July 1968 gas production tests was based on STALLKAT readings. The data show 364 curies of $\mathrm{Kr}-85$ were released to the environment through November of 1969 (AEC, 1971).

The final set of gas production tests were conducted from May 15 - November 6, 1973. The details of how the release data was measured was not found. However, it was assumed that the methodology 
was similar to that mentioned for the tests conducted in 1968. Through November 6, 1973, 48.93 curies of tritium and 4.69 curies of $\mathrm{Kr}-85$ were released to the environment (EPA, 1973). The two sets of production tests are listed in Table A.3-1.

Table A.3-1

\section{Radioactive Release Measurements of Gaseous Effluents During Gasbuggy Production Testing}

\begin{tabular}{|l|c|c|}
\hline \multicolumn{1}{|c|}{ Gas Production Test } & $\begin{array}{c}\text { Kr-85 } \\
\text { (curies) }\end{array}$ & $\begin{array}{c}\text { Tritium } \\
\text { (curies) }\end{array}$ \\
\hline \hline $\begin{array}{l}\text { All production tests through } \\
\text { December of 1969 }\end{array}$ & 364 & 2,432 \\
\hline 1973 Production test & 4.69 & 48.93 \\
\hline All production tests combined & 369 & 2,481 \\
\hline
\end{tabular}

Kr-85 = Krypton-85

Source: EIC, 1971 and EPA, 1973

These results indicate that the level of soil contamination that could have resulted from the flare stack releases would be minimal. This is based on: (1) the $\mathrm{Kr}-85$ radionuclide is a noble gas which would not directly result in soil contamination; (2) the majority (approximately 75 percent) of what was released has decayed away in the 25-year period following the last release based on the half-lives for tritium and $\mathrm{Kr}-85$, the two major nuclides; and (3) the tritium that may have condensed and infiltrated the soil would have dissipated due to evapotranspiration. The half-life for $\mathrm{Kr}-85$ is 10.72 years, and the half-life for tritium is 12.3 years. 


\section{A.4.0 Restoration Activities}

Site restoration activities were conducted over a six-week period in August-September 1978.

Restoration activities included: (1) well plugging and abandonment; (2) decontamination, transport and disposal of equipment; (3) packaging, transport, and disposal of solid and liquid waste; (4) land surface restoration; and (5) final status sampling and analysis (DOE/NV, 1983). This section will concentrate on those activities affecting the amount of radioactivity at the site surface and shallow subsurface today.

\section{A.4.1 Disposal of Radioactive Material}

The facilities and structures at the Gasbuggy Site were dismantled and decontaminated (DOE/NV, 1983). Government-owned materials were shipped to the NTS. Equipment that was used by Eberline Instrument Corporation (EIC) (the AEC contractor for radiation safety) was surveyed and released for unrestricted use and EPNG-owned equipment was returned (DOE/NV, 1983).

Items that were impractical to decontaminate or could not be decontaminated were contained and shipped to the NTS for disposal (DOE/NV, 1983). Ten 55-gallon drums of materials, either known to be slightly radioactive or difficult to make a determination of radioactive content, were sealed, externally steam cleaned, and labeled for shipment as low-level radioactive waste. Nuclides other than tritium and naturally occurring isotopes were not found to be present. The total tritium content of all ten 55-gallon drums was less than 1 millicurie (mCi) (EIC, 1979).

Liquid waste materials consisted primarily of tritium contaminated sludge and liquids from decontamination operations. Approximately 60 55-gallon drums (approximately 3,000 gallons) of tritium-contaminated water and sludge with an average concentration of $1,439 \mathrm{pCi} / \mathrm{mL}$, and 7.3 55-gallon drums of tritium-contaminated water and sludge with an average concentration of $350 \mathrm{pCi} / \mathrm{mL}$ were pumped from the storage tank, and the decontamination sump. The water did not contain other radioactive isotopes above detection limits except naturally occurring radioactive isotopes (see Table A.4-1). This material was injected into the GB-ER cavity before the reentry well was plugged (EIC, 1979). 
Table A.4-1

Reported Results of Additional Analysis for Samples Collected During 1978 Restoration

\begin{tabular}{|c|c|c|c|c|c|c|c|c|c|c|c|}
\hline \multirow[b]{2}{*}{ Description of Sample } & \multicolumn{8}{|c|}{ Gamma-Emitting Isotopes } & \multirow[b]{2}{*}{ 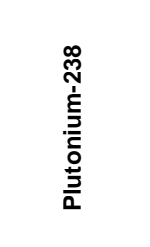 } & \multirow[b]{2}{*}{ 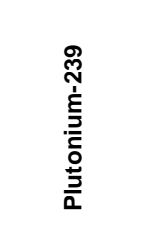 } & \multirow[b]{2}{*}{ 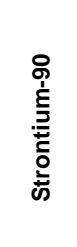 } \\
\hline & 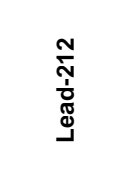 & 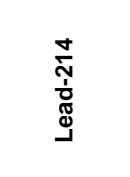 & 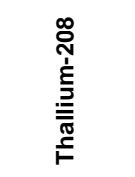 & 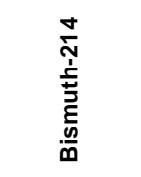 & 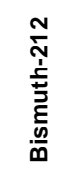 & 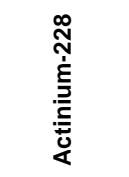 & 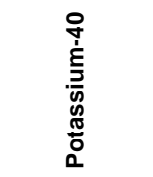 & 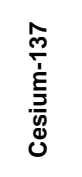 & & & \\
\hline & \multicolumn{11}{|c|}{ Concentration of Isotopes in Liquid Samples (pCi/L) } \\
\hline $\begin{array}{l}\text { Sludge from decon sump and } \\
\text { storage tank that was pumped } \\
\text { down Well GB-ER }\end{array}$ & $400+/-50$ & $300+/-50$ & $200+/-20$ & $300+/-50$ & $<400$ & $100+/-20$ & $2000+/-500$ & $<50$ & NA & NA & $<12.3$ \\
\hline \multirow[t]{2}{*}{ Water and sludge from separator } & $200+/-30$ & $300+/-40$ & $<50$ & $<50$ & $<300$ & $<100$ & $750+/-300$ & $<80$ & NA & NA & $<14.3$ \\
\hline & \multicolumn{11}{|c|}{ Concentration of Isotopes in Solid Samples (pCi/g) } \\
\hline Storage tank sludge & $0.6+/-0.1$ & $0.4+/-0.1$ & $<0.3$ & $<0.3$ & $<2.0$ & $<0.3$ & $<2.0$ & $<0.2$ & $0.0+/-0.02$ & $0.0+/-0.02^{\mathrm{a}}$ & $<0.07$ \\
\hline $\begin{array}{l}\text { Soil sample from profile hole \#1, } \\
1 \text {-foot depth }\end{array}$ & $0.7+/-0.2$ & $0.7+/-0.2$ & $<0.4$ & $0.6+/-0.2$ & $<1.0$ & $<0.3$ & $41+/-6$ & $<0.2$ & NA & NA & $<0.03$ \\
\hline $\begin{array}{l}\text { Soil sample from profile hole \#1, } \\
5 \text {-foot depth }\end{array}$ & $0.9+/-0.2$ & $<0.2$ & $<0.2$ & $0.2+/-0.1$ & $<1.0$ & $<0.2$ & $10+/-2$ & $<0.1$ & NA & NA & $<0.04$ \\
\hline $\begin{array}{l}\text { Soil sample from profile hole \#24, } \\
\text { 4-foot depth }\end{array}$ & $3.0+/-1.0$ & $2.0+/-1.0$ & $1.2+/-0.4$ & $0.4+/-0.2$ & $<2.0$ & $<0.3$ & $41+/-10$ & $<0.2$ & NA & NA & $<0.12$ \\
\hline $\begin{array}{c}\text { Soil sample from forestry road } \\
\# 357 \text { at windmill, distance from } \\
\text { site is } 4.4 \text { miles, depth of sample - } \\
1 \text { foot }\end{array}$ & $2.0+/-1.0$ & $2.0+/-1.0$ & $0.5+/-0.1$ & $0.8+/-0.2$ & $<1.0$ & $<0.2$ & $32+/-5$ & $<0.1$ & NA & NA & $<0.06$ \\
\hline $\begin{array}{l}\text { Soil sample from forestry road } \\
\text { \#357 at windmill, distance from } \\
\text { site is } 4.4 \text { miles, depth of sample - } \\
2 \text { feet }\end{array}$ & $0.7+/-0.2$ & $0.4+/-0.2$ & $<0.3$ & $0.6+/-0.2$ & $<2.0$ & $<0.3$ & $20+/-4$ & $<0.2$ & NA & NA & $<0.05$ \\
\hline
\end{tabular}

${ }^{a}$ Value reflects dry weight of sample $\mathrm{pCi} / \mathrm{L}=$ Picocuries per liter

$<=$ Less than

Source: EIC, 1979 
One hundred seventy-five 55-gallon drums (approximately 9,000 gallons) of low-level tritium-contaminated water was accumulated in a storage tank from the steam decontamination operations after GB-ER was plugged. This water was disposed of by vaporization to the atmosphere using a steam generator. Tritium levels in this water ranged from $14.7 \mathrm{pCi} / \mathrm{mL}$ to $43.7 \mathrm{pCi} / \mathrm{mL}$, and a total of $1.31 \mathrm{mCi}$ was estimated to have been released to the atmosphere over a period of 25 days in September 1978 (EIC, 1979).

\section{A.4.2 On-Site Disposal of Materials}

The historic decontamination area consisted of a concrete pad and asphalt/plastic sump liner. This pad, located in the northwest corner of the site, was broken up and buried in place by enlarging the original sump. Along with the decontamination pad, several other concrete pads from the site were broken up and buried at this location (DOE/NV, 1983). Swipe samples of the concrete pieces were analyzed for beta and tritium activity. The concentrations were less than $(<)$ the LLD. Soil samples taken in the sump prior to backfilling were analyzed and the results were < LLD for tritium (2 $\mathrm{pCi} / \mathrm{mL})$. No radioactive material was disposed of in this burial (EIC, 1979).

Mud and "gel" loaded water used during the well plugging operations was buried on-site at three separate locations. Samples of this material were also taken prior to burial. The sample results were $<$ LLD for tritium (EIC 1979).

\section{A.4.3 Soil Sampling}

Prior to environmental restoration activities (October 1973), EPNG personnel performed radiological soil sampling at the Gasbuggy Site. Data from this sampling event was not published and is not currently available. The EPNG data was used by EIC personnel to plan the 1978 environmental cleanup and sampling investigation. Three types of soil samples were collected by EIC personnel during restoration activities: (1) near surface soil samples, (2) profile (shallow subsurface) soil samples and, (3) operational soil samples. All soil samples were analyzed for tritium in soil moisture. The LLD for tritium contained in the moisture of soil samples was $2 \mathrm{pCi} / \mathrm{mL}$ at three sigma error (EIC, 1979). 
Surface soil sampling points were set on a 50-ft grid. Samples were collected at most of the grid nodes within the fence line (see Figure A.4-1) at a depth of 12 to14 in. bgs. The highest concentration detected, $965 \mathrm{pCi} / \mathrm{mL}$ tritium in soil moisture, was at location near the separators. All of the near surface soil sample results were less than the clearance criterion of $30,000 \mathrm{pCi} / \mathrm{mL}$ tritium in soil moisture established by DOE (EIC, 1979).

Profile soil samples were collected in order to obtain data on the vertical distribution of the tritium concentration with depth. The surface soil sample results guided selection of sampling points for the soil profiles. Originally, 21 profiles were performed to a depth of $6 \mathrm{ft}$. The results from these profile samples determined the selection of more locations and the need to go deeper at several of the first 21 locations. The profile samples were taken at the locations shown on Figure A.4-2 (EIC, 1979).

Thirty-one sets of profile sample results are reported in the Project Gasbuggy Radiation Contamination Clearance Report (see Table A.4-2). Elevated readings were observed at the flare stack and steamer shack locations. A sample collected at a depth of $4 \mathrm{ft} \mathrm{bgs} \mathrm{from} \mathrm{profile} \mathrm{\#} \mathrm{24,} \mathrm{located}$ near the Flare Stack, had the highest tritium result $(1,303 \mathrm{pCi} / \mathrm{mL})$. All of the profile soil sample results were less than the clearance criterion of $30,000 \mathrm{pCi} / \mathrm{mL}$ established by DOE for tritium in soil moisture (EIC, 1979).

Operational soil samples were collected by EIC personnel at 46 locations. Soil samples were taken in support of cleanup whenever a hole needed to be dug or soil disturbed. The sampling method was to remove man-made and vegetative material from the surface. Then a 100 square centimeters area of soil was taken down to a depth sufficient to provide enough moisture for a tritium distillation analysis. The location of these operational soil samples are shown on Figure A.4-3. Seventeen of 46 soil samples had tritium concentrations greater than the LLD. The results for these samples are listed in Table A.4-3 along with a description of their location. Elevated readings were located in the vicinity of the flare stack and steamer shack (EIC, 1979).

In addition, three soil samples collected on site and two off site were analyzed for Sr-90 and gamma-emitting isotopes along with several of the operation waste/water samples. This included the soil sample with the highest tritium concentration (EIC, 1979). The results of these analyses are presented in Table A.4-1. 


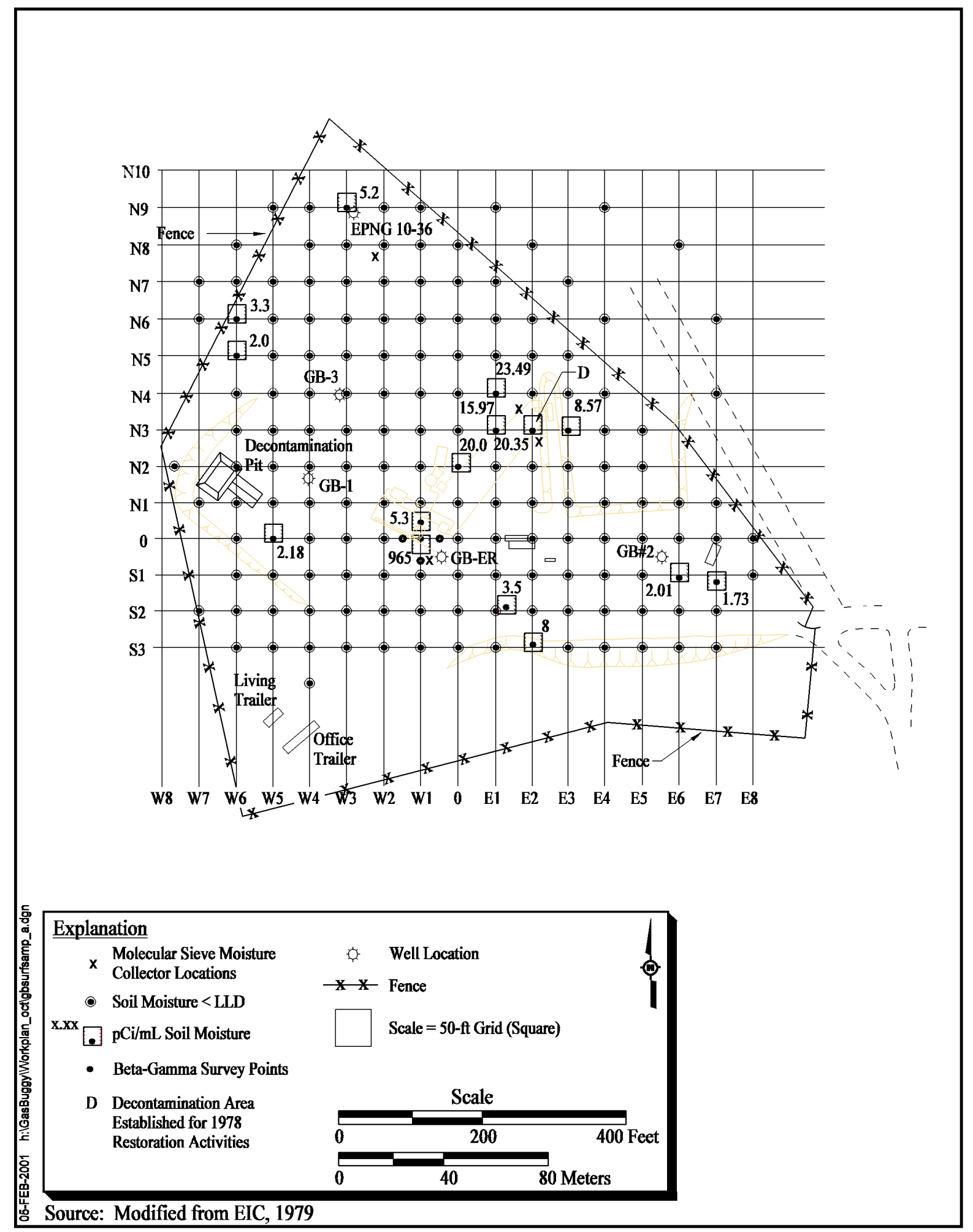

Figure A.4-1 Location of Surface Sampling Points 


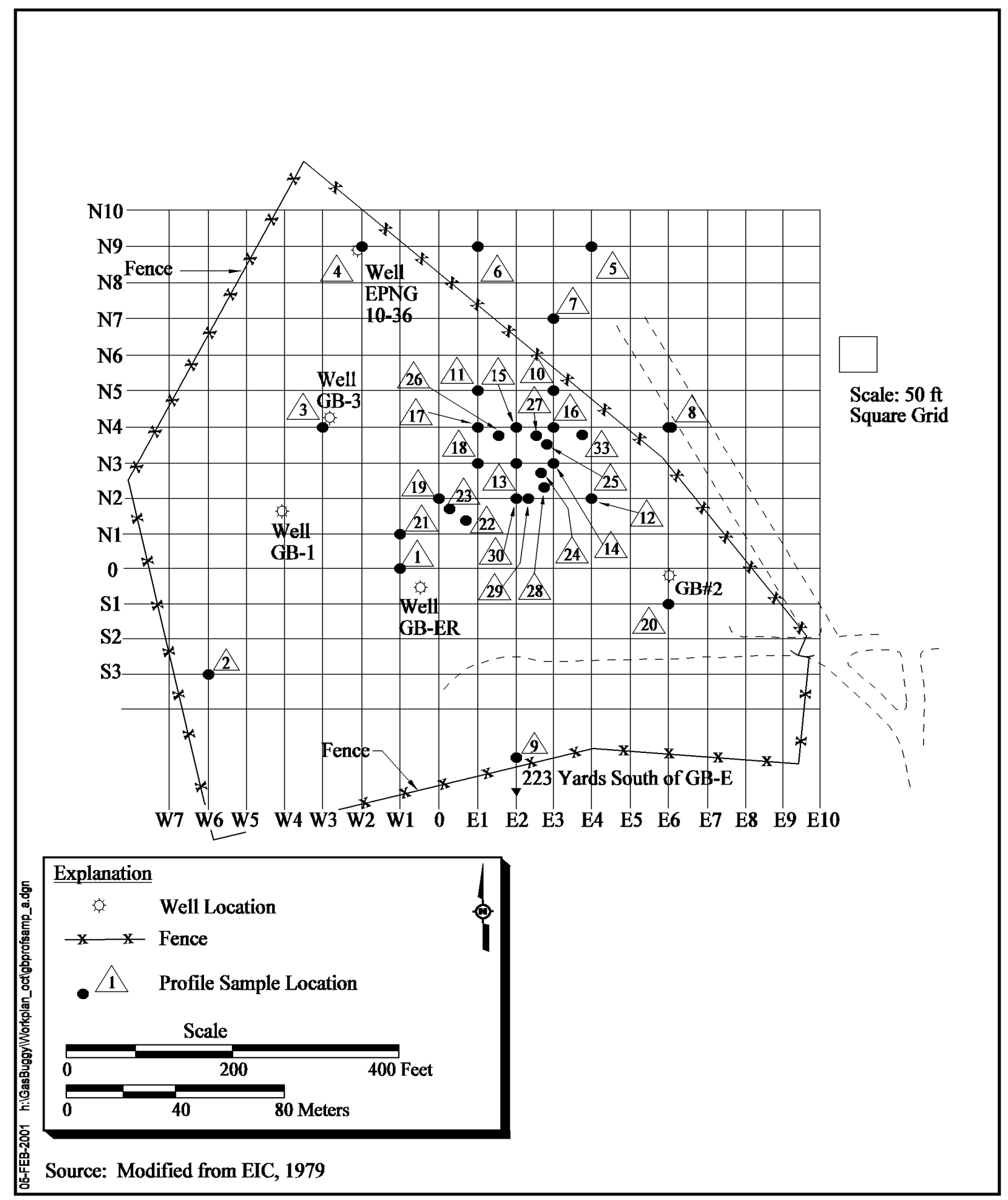

Figure A.4-2 Location of Profile Sample Sets 
Table A.4-2

Results of Profile Sampling Sets

(Page 1 of 4 )

\begin{tabular}{|c|c|c|c|c|c|c|c|c|c|}
\hline Hole & $\begin{array}{c}\text { Grid } \\
\text { Location }^{a}\end{array}$ & $\begin{array}{c}\text { Depth } \\
\text { (ft) }\end{array}$ & $\begin{array}{c}\text { Tritium in } \\
\text { Soil } \\
\text { Moisture } \\
\text { (pCi/mL) }\end{array}$ & $\begin{array}{c}\text { Rerun of } \\
\text { Hole }^{b}\end{array}$ & Hole & Grid Location $^{a}$ & $\begin{array}{c}\text { Depth } \\
\text { (ft) }\end{array}$ & $\begin{array}{l}\text { Tritium in } \\
\text { Soil } \\
\text { Moisture } \\
\text { (pCi/mL) }\end{array}$ & $\begin{array}{l}\text { Rerun } \\
\text { of Hole }\end{array}$ \\
\hline \multirow[t]{10}{*}{1} & \multirow[t]{10}{*}{ W1 N0 } & 1 & 154 & 74.5 & \multirow[t]{6}{*}{5} & \multirow[t]{6}{*}{ E4 N9 } & 1 & $<$ LLD & -- \\
\hline & & 2 & 180 & 69.3 & & & 2 & $2.3(\mathrm{RC}<\mathrm{LLD})$ & -- \\
\hline & & 3 & 234 & 60.7 & & & 3 & $1.9(\mathrm{RC}<\mathrm{LLD})$ & -- \\
\hline & & 4 & 232 & 126 & & & 4 & $<$ LLD & -- \\
\hline & & 5 & 249 & 164 & & & 5 & $<$ LLD & -- \\
\hline & & 6 & 558 & 121 & & & 6 & $<$ LLD & -- \\
\hline & & 7 & -- & 112 & \multirow[t]{6}{*}{6} & \multirow[t]{6}{*}{ E1 N9 } & 1 & $<$ LLD & -- \\
\hline & & 8 & -- & 63.9 & & & 2 & $<$ LLD & -- \\
\hline & & 9 & -- & 40.4 & & & 3 & $<$ LLD & -- \\
\hline & & 10 & -- & 24.7 & & & 4 & $<$ LLD & -- \\
\hline \multirow[t]{6}{*}{2} & \multirow[t]{6}{*}{ W6 S3 } & 1 & $<$ LLD & -- & & & 5 & $<$ LLD & -- \\
\hline & & 2 & $<$ LLD & -- & & & 6 & $<$ LLD & -- \\
\hline & & 3 & $<$ LLD & -- & \multirow[t]{6}{*}{7} & \multirow[t]{6}{*}{ E3 N7 } & 1 & $<$ LLD & -- \\
\hline & & 4 & $<$ LLD & -- & & & 2 & $<$ LLD & -- \\
\hline & & 5 & $<$ LLD & -- & & & 3 & $<$ LLD & -- \\
\hline & & 6 & $<$ LLD & -- & & & 4 & $<$ LLD & -- \\
\hline \multirow[t]{6}{*}{3} & \multirow[t]{6}{*}{ W3 N4 } & 1 & $<$ LLD & -- & & & 5 & $<$ LLD & -- \\
\hline & & 2 & $<$ LLD & -- & & & 6 & $<$ LLD & -- \\
\hline & & 3 & $<$ LLD & -- & \multirow[t]{6}{*}{8} & \multirow[t]{6}{*}{ E6 N4 } & 1 & $<$ LLD & -- \\
\hline & & 4 & $<$ LLD & -- & & & 2 & $<$ LLD & -- \\
\hline & & 5 & $<$ LLD & -- & & & 3 & $<$ LLD & -- \\
\hline & & 6 & $<$ LLD & -- & & & 4 & $<$ LLD & -- \\
\hline \multirow[t]{8}{*}{4} & \multirow[t]{6}{*}{ W2 N9 } & 1 & $<$ LLD & -- & & & 5 & $<$ LLD & -- \\
\hline & & 2 & $<$ LLD & -- & & & 6 & $<$ LLD & -- \\
\hline & & 3 & $<$ LLD & -- & \multirow[t]{6}{*}{9} & \multirow[t]{6}{*}{$\begin{array}{l}223 \text { yards S of } \\
\text { GB-ER on } E 2\end{array}$} & 1 & $<$ LLD & -- \\
\hline & & 4 & $<$ LLD & -- & & & 2 & $<$ LLD & -- \\
\hline & & 5 & $<$ LLD & -- & & & 3 & $<$ LLD & -- \\
\hline & & 6 & $<$ LLD & -- & & & 4 & $<$ LLD & -- \\
\hline & & & & & & & 5 & $<$ LLD & -- \\
\hline & & & & & & & 6 & $<$ LLD & -- \\
\hline
\end{tabular}


Table A.4-2

Results of Profile Sampling Sets

(Page 2 of 4)

\begin{tabular}{|c|c|c|c|c|c|c|c|c|c|}
\hline Hole & $\begin{array}{c}\text { Grid } \\
\text { Location }^{a}\end{array}$ & $\begin{array}{l}\text { Depth } \\
\text { (ft) }\end{array}$ & $\begin{array}{c}\text { Tritium in } \\
\text { Soil } \\
\text { Moisture } \\
\text { (pCi/mL) }\end{array}$ & $\begin{array}{c}\text { Rerun of } \\
\text { Hole }^{b}\end{array}$ & Hole & Grid Location $^{a}$ & $\begin{array}{c}\text { Depth } \\
\text { (ft) }\end{array}$ & $\begin{array}{c}\text { Tritium in } \\
\text { Soil } \\
\text { Moisture } \\
\text { (pCi/mL) }\end{array}$ & $\begin{array}{l}\text { Rerun } \\
\text { of Hole }\end{array}$ \\
\hline \multirow[t]{6}{*}{10} & \multirow[t]{6}{*}{ E3 N5 } & 1 & $<$ LLD & -- & \multirow[t]{6}{*}{14} & \multirow[t]{6}{*}{ E3 N3 } & 1 & 39.9 & -- \\
\hline & & 2 & $<$ LLD & -- & & & 2 & 135 & -- \\
\hline & & 3 & $<$ LLD & -- & & & 3 & 311 & -- \\
\hline & & 4 & $<$ LLD & -- & & & 4 & 422 & -- \\
\hline & & 5 & $<$ LLD & -- & & & 5 & 282 & -- \\
\hline & & 6 & $<$ LLD & -- & & & 6 & 83 & -- \\
\hline \multirow[t]{6}{*}{11} & \multirow[t]{6}{*}{ E1 N5 } & 1 & 13.3 & -- & \multirow[t]{6}{*}{15} & \multirow[t]{6}{*}{ E2 N4 } & 1 & 3.2 & -- \\
\hline & & 2 & $<$ LLD & -- & & & 2 & 10.2 & -- \\
\hline & & 3 & 2.0 & -- & & & 3 & 23.1 & -- \\
\hline & & 4 & $<$ LLD & -- & & & 4 & 39.1 & -- \\
\hline & & 5 & 1.8 & -- & & & 5 & 34.3 & -- \\
\hline & & 6 & 1.6 & -- & & & 6 & 18.8 & -- \\
\hline \multirow[t]{8}{*}{12} & \multirow[t]{8}{*}{ E4 N2 } & 1 & $<$ LLD & 3.8 & \multirow[t]{10}{*}{16} & \multirow[t]{10}{*}{ E3 N4 } & 1 & 9.8 & 9.7 \\
\hline & & 2 & $<$ LLD & 9.2 & & & 2 & 8.6 & 4.6 \\
\hline & & 3 & $<$ LLD & 4.2 & & & 3 & 12.2 & 8.3 \\
\hline & & 4 & $<$ LLD & 7.8 & & & 4 & 10.1 & 10.5 \\
\hline & & 5 & 2.6 & 33.1 & & & 5 & 16.2 & 12.0 \\
\hline & & 6 & 13.4 & 42.3 & & & 6 & 18.8 & 31.2 \\
\hline & & 7 & -- & 44.9 & & & 9 & 71.5 & 53.4 \\
\hline & & 8 & -- & 31.3 & & & 10 & 72.2 & 54.1 \\
\hline \multirow[t]{9}{*}{13} & \multirow[t]{9}{*}{ E2 N3 } & 1 & 52.0 & 15.7 & & & 11 & 71.2 & -- \\
\hline & & 2 & 31.7 & 38.1 & & & 12 & 73.3 & -- \\
\hline & & 3 & 331 & 83.2 & \multirow[t]{6}{*}{17} & \multirow[t]{6}{*}{ E1 N4 } & 1 & 22.3 & -- \\
\hline & & 4 & 131 & 34.6 & & & 2 & 74.3 & -- \\
\hline & & 5 & 919 & 181 & & & 3 & 117.2 & -- \\
\hline & & 6 & 980 & -- & & & 4 & 79.4 & -- \\
\hline & & 6 & 6.8 & -- & & & 5 & 24.0 & -- \\
\hline & & 7 & $<$ LLD & -- & & & 6 & 6.1 & -- \\
\hline & & 8 & $<$ LLD & -- & & & & & \\
\hline
\end{tabular}


Table A.4-2

Results of Profile Sampling Sets

(Page 3 of 4)

\begin{tabular}{|c|c|c|c|c|c|c|c|c|c|}
\hline Hole & $\begin{array}{c}\text { Grid } \\
\text { Location }^{a}\end{array}$ & $\begin{array}{l}\text { Depth } \\
\text { (ft) }\end{array}$ & $\begin{array}{c}\text { Tritium in } \\
\text { Soil } \\
\text { Moisture } \\
\text { (pCi/mL) }\end{array}$ & $\begin{array}{c}\text { Rerun of } \\
\text { Hole }^{b}\end{array}$ & Hole & Grid Location $^{a}$ & $\begin{array}{c}\text { Depth } \\
\text { (ft) }\end{array}$ & $\begin{array}{c}\text { Tritium in } \\
\text { Soil } \\
\text { Moisture } \\
\text { (pCi/mL) }\end{array}$ & $\begin{array}{l}\text { Rerun } \\
\text { of Hole }\end{array}$ \\
\hline \multirow[t]{6}{*}{18} & \multirow[t]{6}{*}{ E1 N3 } & 1 & 6.7 & -- & \multirow[t]{8}{*}{22} & \multirow[t]{8}{*}{$\mathrm{E} 1 \mathrm{~N} 1+10 \mathrm{~N} 18 \mathrm{~W}$} & 1 & 9.3 & -- \\
\hline & & 2 & 20.4 & -- & & & 2 & 7.4 & -- \\
\hline & & 3 & 23.5 & -- & & & 3 & 6.9 & -- \\
\hline & & 4 & 30.7 & -- & & & 4 & 7.3 & -- \\
\hline & & 5 & 24.1 & -- & & & 5 & 23.7 & -- \\
\hline & & 6 & 14.3 & -- & & & 6 & 99 & -- \\
\hline \multirow[t]{6}{*}{19} & \multirow[t]{6}{*}{$0 \mathrm{~N} 2$} & 1 & 4.7 & -- & & & 7 & 298 & -- \\
\hline & & 2 & 7.1 & -- & & & 8 & 218 & -- \\
\hline & & 3 & 6.6 & -- & \multirow[t]{8}{*}{23} & \multirow[t]{8}{*}{$E 1 N 1+16 N 33 W$} & 1 & 2.7 & -- \\
\hline & & 4 & 5.2 & -- & & & 2 & 6.8 & -- \\
\hline & & 5 & 3.0 & -- & & & 3 & 10.2 & -- \\
\hline & & 6 & $<$ LLD & -- & & & 4 & 10.8 & -- \\
\hline \multirow[t]{6}{*}{20} & \multirow[t]{6}{*}{ E6 S1 } & 1 & $<$ LLD & -- & & & 5 & 34.9 & -- \\
\hline & & 2 & $<$ LLD & -- & & & 6 & 49.9 & -- \\
\hline & & 3 & $<$ LLD & -- & & & 7 & 69.9 & -- \\
\hline & & 4 & $<$ LLD & -- & & & 8 & 59.6 & -- \\
\hline & & 5 & $<$ LLD & -- & \multirow[t]{8}{*}{24} & \multirow[t]{8}{*}{$\mathrm{E} 3 \mathrm{~N} 2+45 \mathrm{~N} 17 \mathrm{~W}$} & 1 & 49.3 & -- \\
\hline & & 6 & $<$ LLD & -- & & & 2 & 135 & -- \\
\hline \multirow[t]{11}{*}{21} & \multirow[t]{6}{*}{ W1 N1 } & 1 & $<$ LLD & -- & & & 3 & 434 & -- \\
\hline & & 2 & $<$ LLD & -- & & & 4 & 1303 & -- \\
\hline & & 3 & $<$ LLD & -- & & & 5 & 578 & -- \\
\hline & & 4 & $<$ LLD & -- & & & 6 & 385 & -- \\
\hline & & 5 & $<$ LLD & -- & & & 7 & 186 & -- \\
\hline & & 6 & $<$ LLD & -- & & & 8 & 86.9 & -- \\
\hline & & & & & 25 & $E 3 N 3+27 N 14 W$ & 1 & 16.2 & -- \\
\hline & & & & & & & 2 & 6.6 & -- \\
\hline & & & & & & & 3 & 25.3 & -- \\
\hline & & & & & & & 4 & 61.5 & -- \\
\hline & & & & & & & 5 & 158 & -- \\
\hline
\end{tabular}


Table A.4-2

Results of Profile Sampling Sets

(Page 4 of 4 )

\begin{tabular}{|c|c|c|c|c|c|c|c|c|c|}
\hline Hole & $\begin{array}{c}\text { Grid } \\
\text { Location }^{a}\end{array}$ & $\begin{array}{c}\text { Depth } \\
\text { (ft) }\end{array}$ & $\begin{array}{c}\text { Tritium in } \\
\text { Soil } \\
\text { Moisture } \\
\text { (pCi/mL) }\end{array}$ & $\begin{array}{c}\text { Rerun of } \\
\text { Hole }^{b}\end{array}$ & Hole & Grid Location $^{a}$ & $\begin{array}{c}\text { Depth } \\
\text { (ft) }\end{array}$ & $\begin{array}{c}\text { Tritium in } \\
\text { Soil } \\
\text { Moisture } \\
\text { (pCi/mL) }\end{array}$ & $\begin{array}{l}\text { Rerun } \\
\text { of Hole } \text { Ho }^{b}\end{array}$ \\
\hline \multirow[t]{5}{*}{26} & \multirow[t]{5}{*}{$E 2 N 3+19 N 7 W$} & 1 & 3.2 & -- & \multirow[t]{8}{*}{29} & \multirow[t]{8}{*}{$\mathrm{E} 2 \mathrm{~N} 2+21 \mathrm{E}$} & 1 & $<$ LLD & -- \\
\hline & & 2 & 3.4 & -- & & & 2 & 2.2 & -- \\
\hline & & 3 & 6.4 & -- & & & 3 & $<$ LLD & -- \\
\hline & & 4 & 15.5 & -- & & & 4 & $<$ LLD & -- \\
\hline & & 5 & 35.1 & -- & & & 5 & $<$ LLD & -- \\
\hline \multirow[t]{5}{*}{27} & \multirow[t]{5}{*}{$\mathrm{E} 2 \mathrm{~N} 3+32 \mathrm{~N} 9 \mathrm{E}$} & 1 & 4.9 & -- & & & 6 & 31.5 & -- \\
\hline & & 2 & 13.0 & -- & & & 7 & $<$ LLD & -- \\
\hline & & 3 & 10.6 & -- & & & 8 & $<$ LLD & -- \\
\hline & & 4 & 31.5 & -- & \multirow[t]{8}{*}{30} & \multirow[t]{8}{*}{ E2 N2 } & 1 & $<$ LLD & -- \\
\hline & & 5 & 52.5 & -- & & & 2 & $<$ LLD & -- \\
\hline \multirow[t]{14}{*}{28} & \multirow[t]{8}{*}{$E 3 N 2+21 N 11 W$} & 1 & $<$ LLD & -- & & & 3 & $<$ LLD & -- \\
\hline & & 2 & $<$ LLD & -- & & & 4 & 3.2 & -- \\
\hline & & 3 & $<$ LLD & -- & & & 5 & $<$ LLD & -- \\
\hline & & 4 & $<$ LLD & -- & & & 6 & $<$ LLD & -- \\
\hline & & 5 & $<$ LLD & -- & & & 7 & $<$ LLD & -- \\
\hline & & 6 & 2.5 & -- & & & 8 & 4.9 & -- \\
\hline & & 7 & $<$ LLD & -- & \multirow[t]{8}{*}{$33^{c}$} & \multirow[t]{8}{*}{$E 4 N 3+38 N 19 W$} & 1 & $<$ LLD & -- \\
\hline & & 8 & $<$ LLD & -- & & & 2 & $<$ LLD & -- \\
\hline & & & & & & & 3 & $<$ LLD & -- \\
\hline & & & & & & & 4 & $<$ LLD & -- \\
\hline & & & & & & & 5 & 3.7 & -- \\
\hline & & & & & & & 6 & 6.9 & -- \\
\hline & & & & & & & 7 & 5.1 & -- \\
\hline & & & & & & & 8 & 3.2 & -- \\
\hline
\end{tabular}

${ }^{a}$ For location, see Figure A.4-2. Additional descriptions given after the coordinates refer to distance from coordinate in feet.

bBased on results, samples were recollected or additional samples were collected from Holes 1, 12, 13, and 16.

${ }^{\mathrm{c}}$ The source document (EIC, 1979) does not give results for Sample Sets 31 and 32.

$\mathrm{E}=$ East

$\mathrm{W}=$ West

$\mathrm{N}=$ North

$\mathrm{S}=$ South
$<\mathrm{LLD}=$ Less than the lower limit of detectability (i.e., $2 \mathrm{pCi} / \mathrm{mL}$ )

$\mathrm{RC}=$ Recount (sample was reanalyzed)

-- $=$ No sample collected 


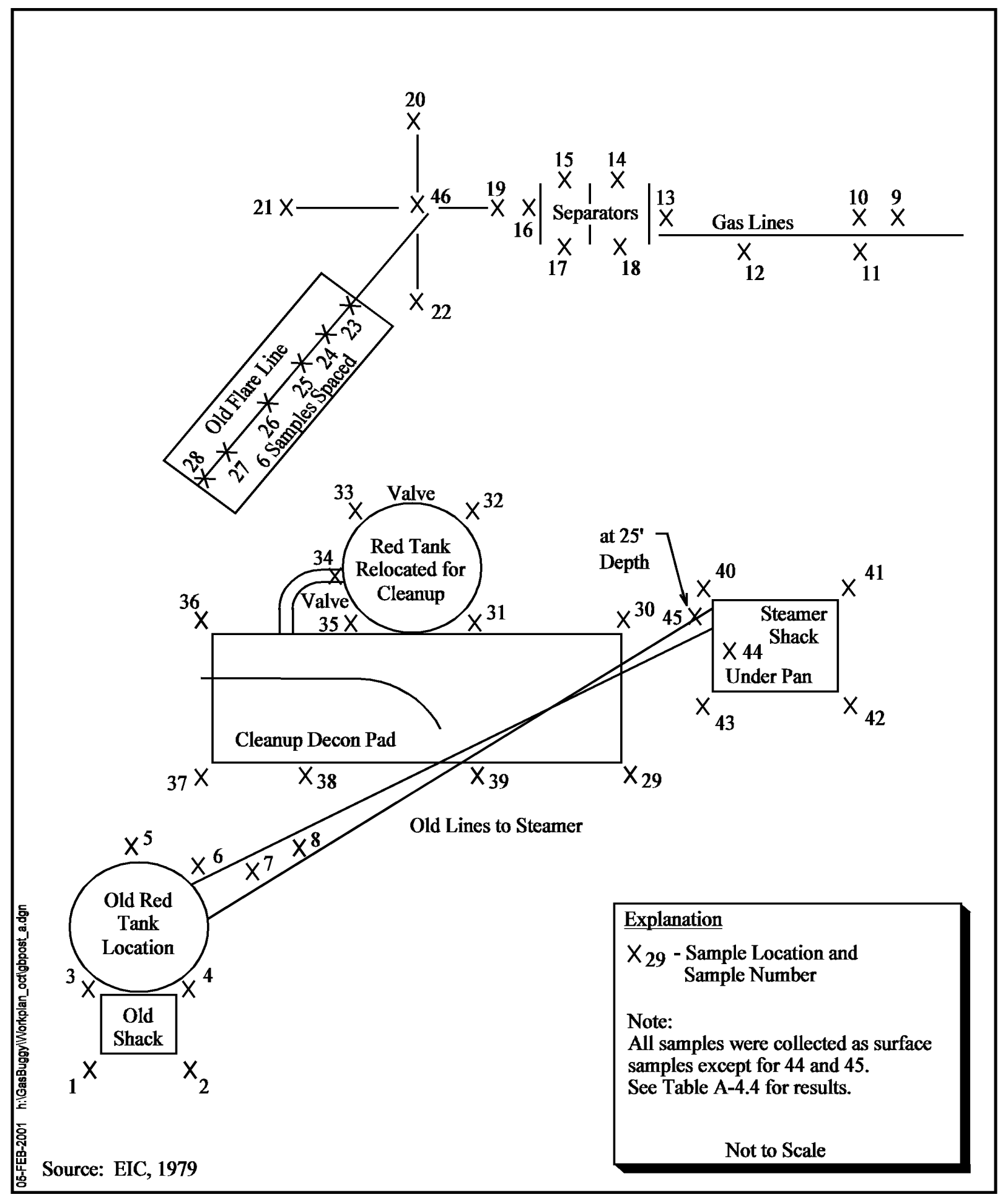

Figure A.4-3 
Table A.4-3

Results for Post-Operational Soil Samples

\begin{tabular}{|c|c|c|c|c|c|}
\hline Sample & Site Location & $\begin{array}{l}\text { Tritium in } \\
\text { Soil } \\
\text { Moisture } \\
\text { (pCi/mL) }\end{array}$ & Sample & Site Location & $\begin{array}{c}\text { Tritium in } \\
\text { Soil } \\
\text { Moisture } \\
\text { (pCi/mL) }\end{array}$ \\
\hline 1 & Near storage tank and pump shack & $<$ LLD & 24 & Along old flare line & $<$ LLD \\
\hline 2 & Near storage tank and pump shack & 3.3 & 25 & Along old flare line & $<$ LLD \\
\hline 3 & Near storage tank and pump shack & $<$ LLD & 26 & Along old flare line & $<$ LLD \\
\hline 4 & Near storage tank and pump shack & $<$ LLD & 27 & Along old flare line & $<$ LLD \\
\hline 5 & Near storage tank and pump shack & $<$ LLD & 28 & Along old flare line & $<$ LLD \\
\hline 6 & Near storage tank and pump shack & $<$ LLD & 29 & $\begin{array}{l}\text { Around new operational location } \\
\text { of storage tank and decon pan }\end{array}$ & $<$ LLD \\
\hline 7 & Along water line from storage tank & $<$ LLD & 30 & $\begin{array}{l}\text { Around new operational location } \\
\text { of storage tank and decon pan }\end{array}$ & 3.0 \\
\hline 8 & Along water line from storage tank & $<$ LLD & 31 & $\begin{array}{l}\text { Around new operational location } \\
\text { of storage tank and decon pan }\end{array}$ & $<$ LLD \\
\hline 9 & Along gas lines & $<$ LLD & 32 & $\begin{array}{l}\text { Around new operational location } \\
\text { of storage tank and decon pan }\end{array}$ & $<$ LLD \\
\hline 10 & Along gas lines & $<$ LLD & 33 & $\begin{array}{l}\text { Around new operational location } \\
\text { of storage tank and decon pan }\end{array}$ & 1.7 \\
\hline 11 & Along gas lines & $<$ LLD & 34 & $\begin{array}{l}\text { Around new operational location } \\
\text { of storage tank and decon pan }\end{array}$ & 10.5 \\
\hline 12 & Along gas lines & $<$ LLD & 35 & $\begin{array}{l}\text { Around new operational location } \\
\text { of storage tank and decon pan }\end{array}$ & 4.0 \\
\hline 13 & Where separators were & $<$ LLD & 36 & $\begin{array}{l}\text { Around new operational location } \\
\text { of storage tank and decon pan }\end{array}$ & 3.9 \\
\hline 14 & Where separators were & $<$ LLD & 37 & $\begin{array}{l}\text { Around new operational location } \\
\text { of storage tank and decon pan }\end{array}$ & 2.6 \\
\hline 15 & Where separators were & $<$ LLD & 38 & $\begin{array}{l}\text { Around new operational location } \\
\text { of storage tank and decon pan }\end{array}$ & 2.4 \\
\hline 16 & Where separators were & 2.5 & 39 & $\begin{array}{l}\text { Around new operational location } \\
\text { of storage tank and decon pan }\end{array}$ & 1.8 \\
\hline 17 & Where separators were & $<$ LLD & 40 & Around steamer shack & 5.9 \\
\hline 18 & Where separators were & $<$ LLD & 41 & Around steamer shack & 6.6 \\
\hline 19 & 6 feet north from GB-ER & $<$ LLD & 42 & Around steamer shack & 2.9 \\
\hline 20 & 6 feet east from GB-ER & 17.3 & 43 & Around steamer shack & 63.1 \\
\hline 21 & 6 feet south from GB-ER & 2.1 & 44 & Under steamer sump & 60.7 \\
\hline 22 & 6 feet west from GB-ER & $<$ LLD & 45 & 2.5 feet under steamer sump & 280 \\
\hline 23 & Along old flare line & $<$ LLD & 46 & At GB-ER & 7.8 \\
\hline
\end{tabular}

$<=$ Less than

LLD = Lower Limit of Detectability

$\mathrm{pCi} / \mathrm{mL}$ - Picocuries per milliliter

Source: EIC, 1979 
The results of this review suggest that, with the exception of tritium, the concentration of radionuclides measured in soil were not distinguishable from natural background levels. Tritium has a half-life of 12.72 years, and the concentrations would now be no more than approximately a quarter of the values measured in 1978. Lastly, no radionuclides other than tritium and naturally occurring radioisotopes were found in soil during the 1978 Gasbuggy restoration effort.

\section{A.4.4 Vegetation Sampling}

Vegetation samples were obtained from six locations on the Gasbuggy Site during the 1978 restoration. Results are presented in Table A.4-4. The tritium concentrations in the vegetation were consistent with the results of soil samples taken in the various areas. The highest concentration of tritium detected in the vegetation was at the flare stack area and measured $470 \mathrm{pCi} / \mathrm{mL}$ (EIC, 1979). This is well below the clearance criterion of $30,000 \mathrm{pCi} / \mathrm{mL}$ established by DOE for tritium in soil moisture (EIC, 1979).

Table A.4-4

Vegetation Sample Results

\begin{tabular}{|c|c|}
\hline Location & $\begin{array}{c}\text { Total Tritium }^{\mathrm{a}} \\
\text { (pCi/mL water) }\end{array}$ \\
\hline \hline South side of road & $2.8+/-0.5$ \\
\hline North side of road & $<3.2+/-0.5$ \\
\hline Storage tank area & $10.4+/-0.3$ \\
\hline Separator area & $7.7+/-0.3$ \\
\hline Flare stack area & $470+/-2.6$ \\
\hline Profile hole \#16 & $7.2+/-0.6$ \\
\hline
\end{tabular}

\footnotetext{
${ }^{\mathrm{a}}$ Free and organically bound water

$\mathrm{pCi} / \mathrm{mL}$ - Picocuries per milliliter

$+/-=$ Plus or minus

$<=$ Less than

Source: EIC, 1979
}

\section{A.4.5 Ground Radiation Surveys}

After all site activity was complete, the area was surveyed for beta-gamma radiation. All readings were $<0.05$ millirad per hour for beta-gamma. 


\section{A.5.0 Post-Restoration Sampling and Monitoring}

Two radiological monitoring efforts have been undertaken at the Gasbuggy Site since the 1978 restoration.

\section{A.5.1 Ground Radiation Survey (1993)}

In June of 1993, the EPA conducted a surface monitoring program. The goal of the program was to assess the extent of contamination and obtain data on the amounts and types of radionuclides at the site for use in future remediation activities. Gamma-ray spectra were obtained in the field with a high purity germanium detector. The total gamma-ray flux was measured with a portable pressurized ion chamber system for comparison with the in situ spectrometry results. Measurements were taken at eight survey locations at or near the site and a ninth location at Gobernador, New Mexico, approximately 10 miles northeast of the site. Results indicated radiation surveys conducted at on-site locations are similar to those taken off site (EPA, 1995).

\section{A.5.2 Aerial Radiation Survey (1994)}

An aerial radiological survey was conducted over the Project Gasbuggy Site on October 27, 1994.

Parallel lines were flown at intervals of $300 \mathrm{ft}$ over a 16 square mile area at a 150-ft altitude centered over the Gasbuggy Site. The purpose of the aerial survey was to detect and document any anomalous gamma radiation in the environment which may have been caused as a result of an underground nuclear detonation and from subsequent production tests. The exposure rates measured within the survey regions were generally uniform and typical of rates resulting from natural background radiation. No evidence of Cs-137 or any other man-made radionuclide was found (EG\&G EM, 1995). 


\section{A.6.0 Conclusion}

Extensive radiological monitoring was conducted during the detonation, gas production operations, site restoration activities, and subsequent to site restoration activities. Data indicate tritium is the only radionuclide of concern for the surface/shallow subsurface of the Gasbuggy Site. Sampling and analysis detected tritium in several soil and vegetation samples. No radionuclides other than tritium and naturally occurring radioisotopes were found in samples taken during the 1978 Gasbuggy restoration effort. 


\section{A.7.0 References}

AEC, see U.S. Atomic Energy Commission.

DHEW, see U.S. Department of Health, Education, and Welfare.

DOE/NV, see U.S. Department of Energy, Nevada Operation Office.

Eberline Instrument Corporation. 1971. On-Site Radiological Safety During Production Testing January 25, 1968 to December 31, 1969, PNE-1006. Sante Fe, NM.

Eberline Instrument Corporation. 1979. Project Gasbuggy Radiation Contamination Clearance Report, PNE-G-89. Sante Fe, NM.

EG\&G EM, see EG\&G Energy Measurements.

EIC, see Eberline Instrument Corporation.

EPA, see U.S. Environmental Protection Agency.

EG\&G Energy Measurements. 1995. An Aerial Radiological Survey of Project Gasbuggy and Surrounding Area, EGG 11265-1129. Las Vegas, NV.

Lawrence Radiation Laboratory. 1968a. Gasbuggy Postshot Investigations in GB-ER, UCRL-50425. Prepared by J.A. Korver and D.E. Rawson. Livermore, CA.

Lawrence Radiation Laboratory. 1968b. Gasbuggy Preliminary Postshot Summary Report, UCRL-50386. Prepared by F. Holzer. Livermore, CA.

LRL, see Lawrence Radiation Laboratory.

U.S. Atomic Energy Commission. 1971. Project Gasbuggy Manager's Report, PNE-G-79, NVO-37. Las Vegas, NV.

U.S. Atomic Energy Commission. 1973. Planning and Operations Directive, Gasbuggy, 1973 Production Testing Program, NVO-137. Las Vegas, NV.

U.S. Department of Energy, Nevada Operations Office. 1978. Project Gasbuggy Well Plugging and Site Restoration Plan, NVO-195. Las Vegas, NV.

U.S. Department of Energy, Nevada Operations Office. 1983. Project Gasbuggy Site Restoration Final Report, PNE-G-90, NVO-211. Prepared by Holmes \& Narver. Las Vegas, NV. 
U.S. Department of Health, Education, and Welfare. 1970. Report of Off-Site Surveillance for Project Gasbuggy March 1967 to June 1968, SWRHL-99R. Washington. DC.

U.S. Environmental Protection Agency. 1973. Results of Sampling Natural Gas Wells in the Vicinity of Project Gasbuggy, NERC-LV-539-9. Las Vegas, NV.

U.S. Environmental Protection Agency. 1995. Surface Radioactivity at the Plowshare Gas-Stimulation Test Sites: Gasbuggy, Rulison, Rio Blanco, EPA 600/R-95/002. Prepared by S.H. Faller. Washington, DC. 


\section{Appendix B}

\section{New Mexico Quality Assurance Project Plan}

(This quality assurance project plan is applicable to all

U.S. Department of Energy, Nevada Operations Office sites in the state of New Mexico.) 


\section{B.1.0 Introduction}

This Quality Assurance Project Plan (QAPP) is a planning document used for the Offsites Project New Mexico Sites by the DOE/NV Environmental Restoration Project (NV ERP). The NV ERP conducts environmental investigation and remediation activities at sites under the oversight of the DOE/NV. It is the policy of the NV ERP to conduct all environmental restoration activities in a manner that produces data of a known quality. Safety is integrated into management and work practices at all levels so that missions are accomplished while protecting the public, the worker, and the environment.

The information provided in this QAPP describes policies, organization, responsibilities, and objectives of the New Mexico Sites and is intended to provide a consistent framework for the collection, evaluation, analysis, and use of data. This QAPP provides for the evaluation of risks associated with the activities to be performed and uses the graded approach to determine the required level of quality assurance. This document supplements, and is to be used in conjunction with, project planning documents which will contain QA/QC requirements appropriate for the site and activities being performed. Attachment 1 of this QAPP delineates the quality criteria that should be addressed in site-specific planning documents. In the event that project objectives or regulatory jurisdiction changes, this document will be reevaluated for adequacy.

The requirements of this QAPP are consistent with those provided in DOE Order 414.1A, Quality Assurance (DOE, 1999). The NV ERP activities shall also be in compliance with DOE Order 440.1A, Worker Protection Management for DOE Federal and Contractor Employees (DOE, 1998), and DOE Order 450.4, Safety Management System Policy (DOE, 1996b). Work at hazardous waste sites shall be conducted in accordance with the applicable sections of 29 Code of Federal Regulations (CFR) 1910.120, Hazardous Waste Operations and Emergency Response (CFR, 1998b), and in accordance with New Mexico Administrative Code regulations for the disposal of hazardous waste.

Work at the New Mexico Sites will be conducted in accordance with the applicable New Mexico Administrative Code regulations and New Mexico Statutes. Should radioactive waste be generated, it shall be handled and disposed of in accordance with 10 CFR Part 71, Subpart H, Packaging and 
Transportation of Radioactive Materials - Quality Assurance (CFR, 1998a), and Nevada Test Site Waste Acceptance Criteria (NTSWAC) (DOE/NV, 1999b). Sites that conduct activities or operations that involve radioactive and/or fissionable materials in such form and quantity that a nuclear hazard potentially exists shall also comply with the relevant parts of 10 CFR 830.120, Quality Assurance Requirements (CFR, 1996).

Figure B.1-1 delineates the hierarchy of documents for NV ERP activities.

\section{QAPP Organization}

The organization of this plan reflects the criteria of DOE Order 414.1A, Quality Assurance (DOE, 1999). The ten criteria therein covers three major areas: management, performance, and assessments. Management entails the planning and preparation required for the successful completion of the New Mexico Sites mission. Additionally, this section incorporates quality improvement processes to enable personnel to detect and prevent quality problems. The performance section establishes the requirements and procedures to be implemented to ensure that newly collected environmental data are valid, that uses of existing data are appropriate, and that methods of environmental modeling are reliable. Assessments provide a feedback loop to Offsites Project management whereby the feedback information can be used to evaluate and, if necessary, modify a system or process to ensure the quality of the product. 


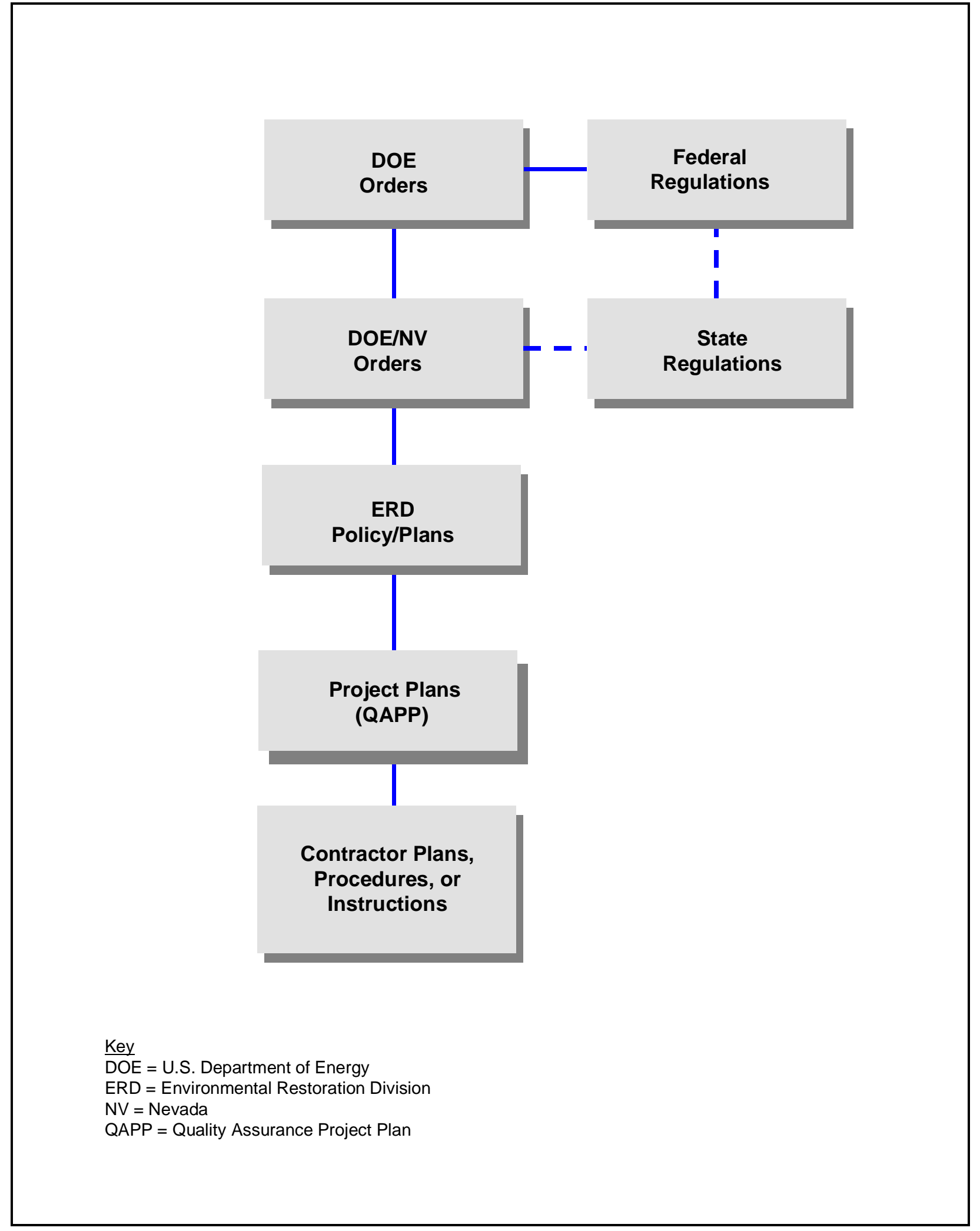

Figure B.1-1

Hierarchy of Documents 


\section{B.2.0 Criteria 1 - Quality Program}

The management systems for the New Mexico Sites encompass the planning and preparation necessary to ensure the successful completion of identified objectives. This QAPP has been prepared to provide the planning and control necessary for effective and efficient work processes. This document provides the overall QA Program requirements and the general quality practices to be applied to activities at the New Mexico Sites. Policy is established, roles and responsibilities are defined, lines of communication are identified, the needs and objectives of the Project are confirmed, and reviews are conducted to ensure (to the extent possible) that all necessary planning and preparation activities have taken place. Low-level radioactive and mixed waste managed under the NV ERP must also meet the requirements of the NTSWAC and the IT Corporation, Las Vegas (ITLV) waste certification program plan. The following sections describe the quality management systems to be employed for the effective management of the New Mexico Sites.

\section{B.2.1 Quality Management Policy}

It is the policy of the NV ERP to provide environmental management that incorporates applicable regulatory requirements. The Quality Management Program described in this document should be implemented for all New Mexico Sites environmental activities to ensure that work is performed in an efficient, controlled manner, and is appropriately documented. Project requirements should be applied on a graded approach, commensurate with the risk of failure of the items or processes and the potential harm those risks pose for human health and the environment. Activities shall conform with applicable federal, state, and local regulations, and contract requirements. Quality will be part of the normal course of work and incorporated from the earliest planning stages to completion of the work.

\section{B.2.2 Project Organization}

The DOE/NV Environmental Restoration Division (ERD) is responsible for the administration of the NV ERP. The NV ERP is a major project under the DOE Office of Environmental Management, Southwestern Area Programs. Personnel from the ERD are assigned project management and technical support responsibilities. All NV ERP Project Managers are responsible for achieving quality within the specific projects they manage. The DOE/NV ERD organization chart is provided in Figure B.2-1. 


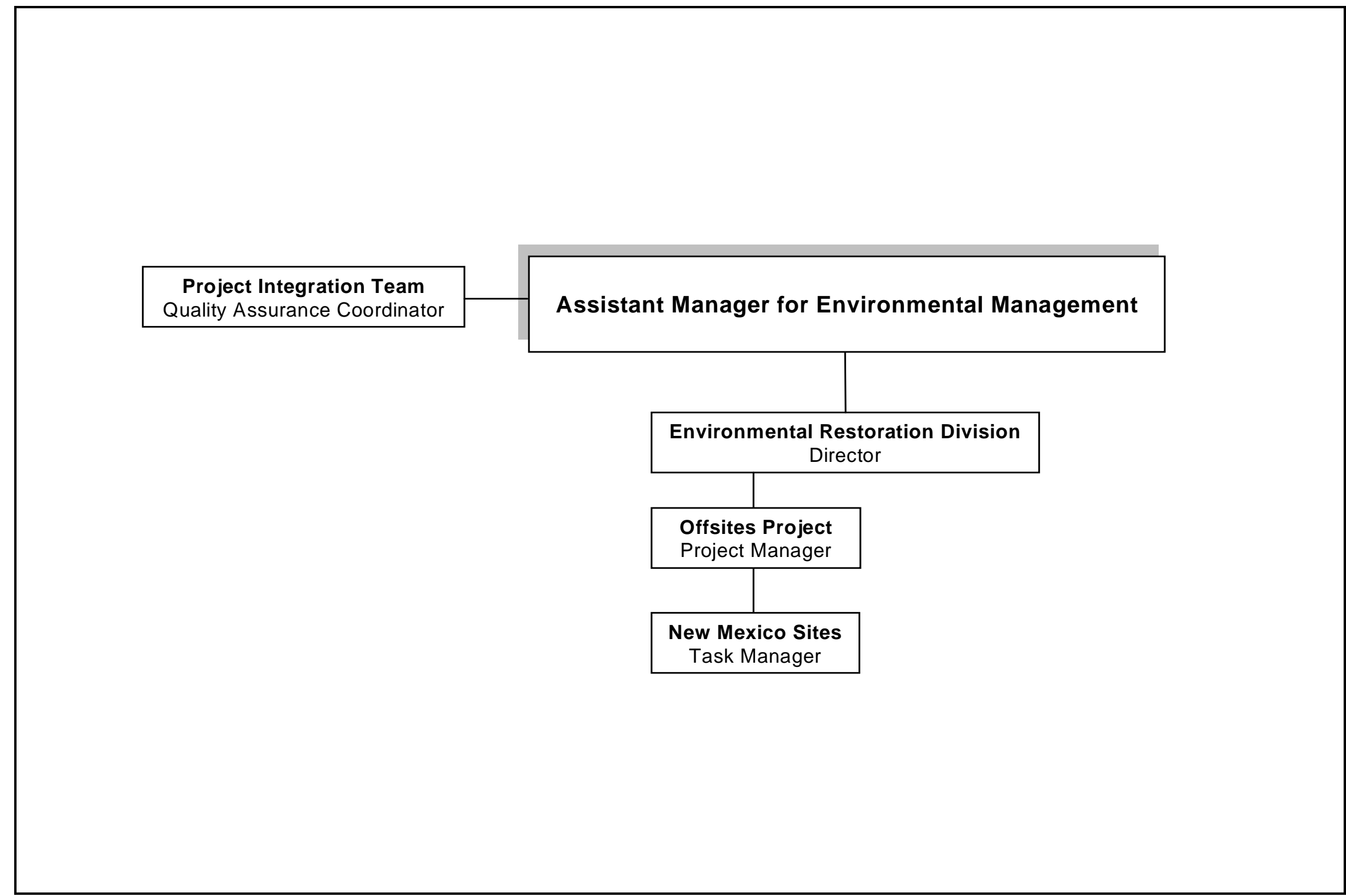

Figure B.2-1

DOE/NV ERD Organizational Chart 
Roles and responsibilities for NV ERP personnel and supporting contractors and organizations (referred to as Project participants) are described in the following sections.

\section{B.2.3 DOE/NV ERD Director}

The DOE/NV ERD Director has oversight and management responsibilities for all projects under the NV ERP and is responsible for the scope and implementation of the QA Program defined in this document. The Director is the senior management official responsible for ensuring that this QAPP is established, that quality requirements are implemented, and that opportunities for improvement are identified and incorporated.

\section{B.2.3.1 NV ERP Project Manager}

The NV ERP Project Manager reports directly to and is the prime point-of-contact with the DOE/NV ERD Director. The NV ERP Project Manager has day-to-day management responsibilities for technical, financial, and scheduling aspects of his/her assigned project and shall monitor contractor performance of project activities. At a minimum, the DOE/NV Project Manager is responsible for the following duties:

- Review, approve, and direct the implementation of NV ERP project-specific plans.

- Disseminate pertinent information from DOE/NV to NV ERP participants.

- Review and approve changes to NV ERP project-specific documents.

- Monitor the activities of participating organizations and provide direction and guidance for improvement.

- Verify Project participants are adequately executing the responsibilities as delineated in this section.

- $\quad$ Notify and apprise the DOE/NV ERD Director and DOE/NV ERP Quality Assurance Coordinator (QAC) of significant conditions adverse to quality.

- Act as the point-of-contact for state regulator for all aspects of the project. 


\section{B.2.3.1.1 NV ERP Task Manager}

The NV ERP Task Managers report directly to their respective NV ERP Project Managers. The Task Managers have day-to-day management responsibilities for technical and scheduling aspects of the assigned project task and shall monitor contractor performance of task activities. At a minimum, the Task Managers are responsible for the following duties:

- Ensure effective communication among contractors performing work for their assigned tasks.

- Participate in the organization and planning of activities.

- Perform periodic assessments (such as surveillances) of activities under their purview.

- Monitor the activities of participating organizations and provide direction and guidance for improvement.

- Notify the responsible NV ERP Project Manager and other involved personnel of significant conditions adverse to quality.

\section{B.2.3.1.2 NV ERP Quality Assurance Coordinator}

The NV ERP QAC has a direct line of communication with the DOE/NV ERD Director and the NV ERP Project Managers. The NV ERP QAC will provide the overall direction of the QA function. At a minimum, the NV ERP QAC shall have the following duties:

- Identify and respond to QA/QC needs of the NV ERP and provide QA/QC guidance or assistance to individual Project Managers and Task Managers.

- Verify that systems are in place to evaluate data against analytical quality criteria.

- Verify that appropriate corrective actions are taken for nonconforming conditions.

- Notify the DOE/NV ERD Director, the individual NV ERP Project Managers, and other involved personnel, of significant conditions adverse to quality or any adverse trends.

\section{B.2.3.2 New Mexico Sites Project Participants}

Project participants, such as supporting contractors and organizations, are responsible for developing the necessary procedures for their assigned scope of work and ensuring that work is performed in accordance with applicable federal, state, and local regulations, and approved NV ERP project plans 
and procedures consistent with individual contracts and agency agreements. To fulfill responsibilities specific to QA, participants shall, at a minimum, be responsible for the following:

- Report to the NV ERP Project Managers or NV ERP Task Managers concerning scope, schedules, costs, technical execution, and quality achievement of task order activities.

- Ensure the proper resources are provided for QA activities and that QA activities are integrated into project activities.

- Evaluate activities to ensure that planning document requirements are implemented.

- Implement applicable procedures and instructions that govern NV ERP activities.

- Verify that work is technically sound, of acceptable quality, and is consistent with project objectives.

- Ensure personnel are trained and qualified to achieve initial proficiency, maintain proficiency, and adapt to changes in technology, methods, or job responsibilities.

- Perform assessments, as applicable, to verify compliance with applicable requirements.

- Identify deficient areas and implement effective corrective action for quality problems.

- $\quad$ Notify the NV ERP Project Managers, the NV ERP Task Managers, and other involved personnel of significant conditions adverse to quality or any adverse trends.

- Verify that appropriate corrective actions are taken for nonconformances.

\section{B.2.3.3 Analytical Laboratories}

Analytical laboratories used to support the NV ERP are responsible for ensuring that samples are received, handled, stored, and analyzed according to the analytical laboratory's QA program and contract requirements. Analytical laboratories performing data analysis shall participate in Performance Evaluation Sample Programs appropriate for analyses performed and be subject to periodic audits. Subcontracted analytical services are subject to the same requirements. Verification of subcontractor conformance is the responsibility of the contracting organization. 


\section{B.2.4 Planning}

The NV ERP and participant personnel responsible for oversight of data collection operations should verify that the data-collection system design is defined, controlled, verified, and documented. All planning shall incorporate the principles of Integrated Safety Management to mitigate hazards to workers, the public, and the environment. A graded approach to data quality requirements shall be used to meet the sampling objectives and data needs of a given site and the dynamic nature of the program. Work assignments should be clearly communicated with lines of communication established among all participants. Organizations assigned lead responsibilities shall coordinate project planning with decision makers and participating organizations.

\section{B.2.4.1 Task Initiation}

A project kickoff meeting should be conducted at the beginning of each task. This meeting should brief key personnel assigned to the task on the purpose of the task, the expected outcome, the schedule for the task, and personnel responsibilities for completion of the effort. The responsible manager should monitor the planning process to ensure communication of status, to assess progress, and to implement any corrective action needed to achieve timely completion.

\section{B.2.4.2 Data Quality Objectives}

When appropriate, planning and scoping for environmental data/information needs will include the use of the DQO process to determine the type, quantity, and quality of the data to be collected and the appropriate use of such data. Participants in the DQO process for each operation should include representatives of all data users and decision makers involved with that operation. The DQO process provides a systematic procedure for defining the criteria that a data collection design should satisfy. The appropriate DOE/NV ERD personnel, NV ERP participants, and state regulators will jointly establish DQOs for each site, or group of similar sites, to allow the work to be planned in a manner that will ensure data will meet the needs of the end users. Representatives from these organizations should include data users and decision makers. 
The most current version of EPA QA/G-4, Guidance for the Data Quality Objectives Process (EPA, 1994a), or an equivalent approach that incorporates the applicable elements of QA/G-4, should be used to develop DQOs. The DQO process should:

- Clarify the study objective.

- Define the most appropriate type of data to collect.

- Determine the most appropriate conditions from which to collect the data.

- Specify tolerable limits on decision errors which will be used as the basis for establishing the quantity and quality of data needed to support the decision.

Results of the DQO process shall be documented and project participants shall use the DQOs to develop a scientific and resource-effective data collection design.

\section{B.2.5 Quality Indicators}

Data quality indicator goals are qualitative and quantitative statements that specify the data requirements for the project. Sample analytical data goals are based on the intended use of the data, current field procedures, instrumentation, and available resources. Quality indicator goals are established during the site-specific DQO process to properly support the overall project or sampling task objectives. An evaluation of the quality indicators shall be performed during the assessment of data to determine if the goals set during the DQO process have been accomplished. Indicators of data quality as they relate to data collection and laboratory analysis include precision, accuracy, representativeness, completeness, and comparability.

\section{B.2.5.1 Precision}

Precision measures the reproducibility of data under a given set of conditions. Specifically, precision is a quantitative measurement of the variability of a population of measurements compared to their average value. Precision for inorganic analyses shall be assessed by collecting, preparing, and analyzing duplicate field samples and by creating, preparing, and analyzing laboratory duplicates from one or more field samples. Precision for organic analyses shall be assessed by collecting, preparing, and analyzing matrix spike (MS) and matrix spike duplicate (MSD) samples. Precision will be reported as relative percent difference (RPD). The RPD is calculated as the difference 
between the measured concentrations of Sample 1 and Sample 2, divided by the average of the two concentrations, and multiplied by 100. If the RPD exceeds predetermined limits for a given parameter, the data shall be evaluated for usability based on the purpose for the data and reasons for the increased RPD. This evaluation must be documented.

\section{B.2.5.2 Accuracy}

Analytical accuracy is defined as the nearness of a measurement to the true or accepted reference value. It is the composite of the random and systematic components of the measurement system and measures bias in a measurement system. Accuracy measurements for spike samples and laboratory control samples shall be calculated as percent recovery, which is calculated by dividing the measured sample concentration by the true concentration and multiplying the quotient by 100 . The percent recovery shall be within the limits defined in site-specific plans. Values exceeding the acceptance criteria, established during the site-specific DQO process, must be evaluated for corrective actions.

Field accuracy is assessed by confirming that the documents of record track the sample from origin, through transfer of custody, to disposal. The goal of field accuracy is for all samples to be collected from the correct locations, at the correct time, placed in a correctly labeled container with the correct preservative, and sealed with custody tape to prevent tampering.

\section{B.2.5.3 Representativeness}

Representativeness expresses the degree to which sample data accurately and precisely represent a characteristic of a sample population, a parameter variation at a sampling point, a process condition, or an environmental condition (EPA, 1998). Representativeness depends on the proper design and execution of a sampling program and it will be achieved through careful selection of sampling intervals and locations as well as analytical parameters and the correct collection methods.

The number of samples collected must be sufficient to demonstrate that the data represent the population of interest to the statistical certainty required by the DQOs. Collection, storage, handling, and transport of samples should be performed in a manner that preserves the in situ characteristics of the samples and maintains the representativeness of the sample to the site. 


\section{B.2.5.4 Completeness}

Page B-12 of B-69

Completeness is a measure of the amount of valid data obtained from a measurement system compared to the amount that was expected to be obtained under correct, normal conditions (EPA, 1998). Completeness is affected by unexpected conditions that may occur during the data collection process. The number of samples prescribed for an activity must be sufficient to meet data requirements identified in the DQO process and must consider typical loss of data caused by handling, shipping, and analytical processes.

\section{B.2.5.5 Comparability}

Comparability is a measure of the confidence with which one dataset or method can be compared with another (EPA, 1998). Comparability is achieved by using standard techniques and procedures (e.g., standard operating procedures) to collect and analyze representative samples and by reporting analytical results in appropriate units. Comparability is limited by the other quality indicators because only when precision and accuracy are known can datasets be compared with confidence.

\section{B.2.6 Reports to Management}

Contractor management and NV ERP Project Managers shall be made aware of project activities and shall participate in the development, review, and operation of these activities. Management shall be informed of quality-related activities through the receipt, review, and/or approval of:

- $\quad$ Project-specific plans and procedures

- Assessment reports

- Corrective action requests, corrective actions, and schedules

- Nonconformance reports (NCR)

Individuals identifying nonconforming conditions or deficiencies are responsible for documenting and reporting said conditions. All nonconformances and findings related to quality shall be corrected as required, documented, and properly reported. In addition, periodic assessment of QA/QC activities and data quality parameters shall be evaluated and reported to the participating project field and laboratory management. 


\section{B.2.7 Readiness Reviews}

Readiness reviews shall verify that all planning documents and processes are in place for the successful and efficient accomplishment of the mission. The readiness review includes verification that personnel are qualified and knowledgeable in the activities they are assigned to perform.

Readiness reviews shall be performed by participating organizations prior to the start of any major scheduled activity and prior to restarting work (following stop work orders) to verify and document that project planning and prerequisites have been satisfactorily completed. At a minimum, readiness reviews shall verify that the following issues have been addressed:

- The scope of work is compatible with project objectives.

- The planned work is appropriate to meet objectives.

- Work instructions have been reviewed for adequacy and appropriateness, formally approved, and issued to personnel who will be performing the work.

- Hazards have been identified, analyzed, categorized, and controls implemented.

- Proper resources (e.g., personnel, equipment, and materials) have been identified and are available.

- Assigned personnel have read the applicable work instructions and have been trained and qualified.

- Internal and external interfaces have been defined.

- Proper work authorizations and permits have been obtained.

- The calibration of all material and test equipment is current.

- A feedback mechanism has been established to facilitate process improvement. 


\section{B.3.0 Criteria 2 - Personnel Training and Qualifications}

The NV ERP and project participant management shall ensure that personnel are qualified and knowledgeable in the activities they perform. Training should emphasize correct performance of assigned work and provide an understanding of quality requirements. Personnel qualification and training records shall be maintained as quality documents in accordance with DOE Order 414.1A, Quality Assurance (DOE, 1999).

\section{B.3.1 Project Personnel}

Personnel shall be trained and qualified to perform the tasks to which they are assigned. Objective evidence of qualifications may include academic credentials, personal resumes, registrations and/or certifications, licenses, and training records. The qualifications of personnel shall be evaluated against assigned responsibilities and any identified training needs must be addressed.

Training should be provided to achieve and maintain proficiency; adapt to changes in technology, methods, or job description; and allow for feedback and effectiveness of job performance. Training may take the form of orientation and/or indoctrination, formal classroom training, or on-the-job training. This training should include regulatory requirements, scopes of work, QA/QC requirements, and applicable work instructions.

Any required on-the-job training should be conducted and documented by personnel experienced in the task being performed in accordance with each organization's requirements. Any work performed by a trainee should be under the supervision of an experienced individual. Trainees should demonstrate capability prior to performing work independently.

\section{B.3.2 Subcontractor Personnel}

Subcontractor personnel shall be qualified and trained to perform the duties for which they were contracted. The contracting organization shall be responsible for verifying the qualifications of their subcontractors. 


\section{B.4.0 Criteria 3 - Quality Improvement}

An objective of the New Mexico Sites activities is to produce quality products and to continuously seek methods to improve both processes and products. Processes shall be established with the objective of preventing problems and improving quality. Peer reviews of various work products should be built into the work processes to ensure the quality of the products prior to release. All personnel are encouraged to identify and suggest improvements in all areas of work performed for the New Mexico Sites.

Management shall seek to cultivate an atmosphere which fosters the belief that improvement is always possible, and accountability and excellence must be established at all levels. It is equally important to identify and implement process improvements and efficiencies. Successful techniques should be evaluated to determine the potential for performance improvements in other areas or projects. The following sections identify processes that, at a minimum, shall be implemented.

\section{B.4.1 Internal Quality Control Checks}

Quality control checks shall be performed for data collected in the field and data obtained through on-site and/or off-site analysis. Information shall be reviewed by someone other than the originator to ensure correct collection, transcription, and manipulation. Transcribed data shall be verified to ensure the correctness of the transcription. Data that has been manipulated shall be checked to ensure the manipulation process was performed as the originator intended.

Proprietary computer applications used for the evaluation of historical data maintained or transferred via electronic media shall have QC checks performed that are appropriate to the application being used. These checks must be documented and maintained in accessible files.

Field sampling and laboratory analytical activities shall incorporate QC procedures. All field and laboratory operations and systems shall be evaluated for their potential to impact the quality of generated data. System quality controls that meet the requirements of this QAPP shall be established and documented through the use of approved procedures, plans, or instructions. 
The QC samples shall be incorporated into the analytical stream to assess the overall data quality produced by the program. The QC samples consist of field- and laboratory-generated samples which are used to evaluate sampling and analytical precision and accuracy as well as the levels of potential contamination introduced by the sampling and analytical effort. The following paragraphs describe the QC samples that will be generated.

\section{B.4.1.1 Field Quality Control}

The field data collection QC program is designed to provide confidence that data collected during field activities adequately represents the area of interest. For sampling activities, field QC samples provide a mechanism for assessing and documenting that the collection process meets the QA objectives of the project. The number and type of field QC samples required shall be determined during the planning process for each site. Field QC samples include, as applicable, trip blanks, equipment rinsate blanks, source blanks, field blanks, and field duplicates. Field QC samples shall be submitted to the laboratory in such a manner that the laboratory is not aware that the sample is for QC purposes. Collection and documentation of field QC samples shall be in accordance with approved procedures and site-specific plans. Other types of data collected, such as observational data and measurements, shall have the appropriate quality control checks applied to ensure the information collected is of a quality that meets the objectives of the activity.

\section{B.4.1.1.1 Equipment Rinsate Blank Samples}

An equipment rinsate blank is collected from the final rinse solution from the equipment decontamination process to determine the effectiveness of the decontamination process. The blanks shall be prepared by pouring deionized water through or over a sampling device after it has been decontaminated and prior to using the device for environmental sample collection. Care shall be taken to ensure that each part of the sample device which comes in contact with the sample is included in the rinse. If equipment rinsate blank analytical results indicate possible contamination of samples, environmental sample results shall be reviewed to determine whether qualifiers should be assigned to the data or whether the source should be resampled. Results of rinsate blank analyses shall be maintained with the corresponding sample analytical data in the laboratory records file and reported in the laboratory data package. One equipment rinsate blank sample shall be collected for each method of equipment decontamination employed. 


\section{B.4.1.1.2 Field Blank Samples}

Page B-17 of B-69

Field blanks are collected and analyzed by the laboratory to determine if contamination in the air during sample collection and packaging may have contaminated the samples. The field blanks are prepared by pouring deionized water or solid material that is certified to be without the contaminants of concern into clean sample containers in the field near the sampling locations, or by exposing a clean swipe to the same ambient conditions as those present during sampling. Field blanks should be collected as closely in time and space to the environmental sample as possible. If field blank analytical results indicate possible contamination of associated samples, environmental sample results shall be reviewed to determine whether qualifiers should be assigned to the data or whether the source should be resampled. One field blank is collected for each 20 samples collected. Field blanks shall be analyzed for the same analytical suite as the samples being collected.

\section{B.4.1.1.3 Trip Blank Samples}

A trip blank is a 40-milliliter volatile organic analysis (VOA) container of organic-free water that is shipped to the field along with the other VOA sample containers. The blank is not opened, but is otherwise maintained, handled, stored, packaged, and shipped as if it were collected in the field. The purpose of the trip blank is to determine if contaminants have entered the sample through diffusion across the Teflon ${ }^{\mathrm{TM}}$-faced, silicone rubber septum of the sample vial during the performance of laboratory, field, or shipping procedures. The trip blank is only analyzed for volatile organic constituents. Trip blanks shall be submitted for analysis at a frequency of one sample per shipping container that contains field VOA samples. If trip blank analytical results indicate possible contamination, environmental sample results shall be reviewed to determine whether qualifiers should be assigned to the data.

Following the analyses, if the trip blanks indicate possible contamination of the samples, the appropriate project personnel shall be notified. Results of trip blank analyses shall be maintained with the corresponding sample analytical data in the laboratory records file and reported in the laboratory data package. 


\section{B.4.1.1.4 Duplicate Samples}

Page B-18 of B-69

Field duplicates are QC samples that are collected as closely in time and space to the environmental sample as possible to assess sample variability and to measure sampling and analytical variability. Collection of the required number of duplicates shall be evenly distributed throughout the sampling activity. One duplicate shall be collected for each 20 samples collected. The field duplicates shall mirror the sampling and analytical profile of the original sample and be assigned a unique sample number. The duplicate sample number shall not indicate that it is a QC sample to minimize handling, analysis, and data-evaluation bias. Parameters to be analyzed shall be the same as those analyzed for the corresponding environmental samples. Sample management and documentation procedures for duplicates shall be the same as those used for environmental samples. When the RPD results between the environmental sample and its duplicate are outside control limits, environmental results will be reviewed to determine whether qualifiers should be assigned to the data.

\section{B.4.1.1.5 Source Blanks}

A minimum of one source blank shall be collected from each source of water used for project activities to include decontamination. Source blanks shall be analyzed for the same parameters as the original samples. Source blanks shall be collected as close to the source as practical, but may be collected from on-site storage containers.

\section{B.4.1.2 Analytical Laboratory Quality Control}

All on-site and off-site analytical laboratories performing analyses for the New Mexico Sites shall conduct their activities in accordance with a written and approved QA plan. Laboratory quality control (LQC) samples shall be analyzed using the same analytical procedures used to analyze environmental samples. Each analytical laboratory shall generate QC samples during each analytical run to assess and document accuracy and precision associated with each analytical measurement in accordance with the laboratory QA plan. All data from concurrently analyzed LQC samples and other quality controls which are used to demonstrate analytical control shall be included in the laboratory's analytical report. The requirements for the types and number of LQC samples will depend on the analytical procedure or method and the laboratory's QA objective for each test. 
Laboratory quality control samples include Laboratory Control Samples (LCS), method blanks, surrogate-spike, and MS/MSD samples.

\section{B.4.1.2.1 Laboratory Control Samples}

One LCS shall be prepared and analyzed with each batch of samples per matrix. The LCS shall be carried throughout the sample preparation and analysis procedures to assess laboratory accuracy and precision. The LCS shall be analyzed concurrently with each analytical batch for each analyte of interest and shall be prepared from standards independent of the calibration standard. Control limits for recovery shall be established, and recovery data shall be plotted on internal control charts. The LCS data outside these recovery limits shall be considered "out of control," and the laboratory shall initiate corrective action(s) that shall be performed in accordance with the laboratory's QA plan. Results of duplicate LCS analyses shall be reported as RPD and percent recovery and included with the associated analytical report. When LCS percent recovery is outside the control limits, environmental sample results will be reviewed to determine whether qualifiers should be assigned to the data.

\section{B.4.1.2.2 Method Blank Samples}

Method blanks shall be analyzed by the laboratory to check for instrument contamination and contamination and interference from reagents used in the analytical method. A method blank shall be concurrently prepared and analyzed for each analyte of interest for each analytical batch. Method blank data outside statistical control limits shall be considered "out of control," and corrective action(s) shall be performed in accordance with the laboratory's QA plan. Method blank data shall be reported in the same units as the corresponding environmental samples, and the results shall be included with each analytical report.

\section{B.4.1.2.3 Surrogate-Spike Samples}

Surrogate-spike sample analysis shall be performed for all samples analyzed by gas chromatography (GC), gas chromatography/mass spectrometry (GC/MS), and High Performance Liquid Chromatography (HPLC) to monitor laboratory performance and analytical procedures on a sample-by-sample basis. Surrogate standards are nontarget compounds added to GC, GC/MS, and HPLC standards, blanks, and samples prior to extraction or purging. Surrogate compounds are 
compounds that are not expected to be present in the associated environmental samples but behave similar to target compounds chromatographically. Surrogate compounds and concentrations added shall be those specified in the applicable analytical method. Recovery values for surrogate compounds shall be within the control limits specified by the laboratory and in accordance with assessment procedures in the laboratory's QA plan, or the analysis shall be repeated. Results of surrogate-spike sample analyses shall be reported as percent recovery. When surrogate percent recovery is outside the control limits, environmental sample results will be reviewed to determine whether qualifiers should be assigned to the data.

\section{B.4.1.2.4 Matrix-Spike/Matrix-Spike Duplicate Samples}

Project site-specific MS/MSD samples shall be analyzed by the laboratory to determine interferences of the sample matrix on the analytical methods and subsample variance of the laboratory data. A separate sample aliquot shall be spiked with the analytes of interest and analyzed with every 20 samples per matrix or, if fewer than 20 samples were collected, at least one of the samples shall be spiked. Results of the MS/MSD analyses shall be reported as percent recovery and RPD and included with the analytical report. Results that are outside the established recovery or reproducibility limits for the analytical method shall be considered "out of control," and the laboratory shall initiate corrective action(s) that shall be performed in accordance with the laboratory's QA plan. When the RPD results between the MS and MSD samples are outside control limits, environmental results will be reviewed to determine whether qualifiers should be assigned to the data. The MS/MSD samples shall not be collected for radiochemical analysis.

\section{B.4.1.2.5 Laboratory Duplicate Samples}

Two aliquots of the same sample per matrix shall be prepared and analyzed for inorganic analysis, and the duplicate results will be used to calculate the precision as defined by the RPD. If the precision value exceeds the control limit, the appropriate laboratory personnel will identify the root cause of the nonconformance and implement corrective actions. A laboratory duplicate analysis shall be performed with every 20 samples. When the RPD results between the environmental sample and its lab duplicate are outside control limits, environmental results will be reviewed to determine whether qualifiers should be assigned to the data. 


\section{B.4.1.3 On-Site Radiological Laboratory Quality Control}

On-site radiological laboratory analysis may be performed for direct counting of soils by gamma spectral analysis. Any on-site laboratory analysis shall be performed in accordance with written, approved work instructions by trained personnel using properly calibrated equipment. Gamma spectroscopy requires physical preparation of the sample and direct counting. QC checks required shall verify the accuracy and precision of the counting system. A National Institute for Standards and Technology (NIST)-traceable mixed gamma standard shall be used.

\section{B.4.1.3.1 Instrument Control Samples}

An instrument control sample shall be analyzed with each batch of samples. The control sample shall be carried through the analysis procedures to assess laboratory accuracy and precision. Control limits for recovery shall be established, and recovery data shall be plotted on internal control charts.

\section{B.4.1.3.2 Blank Samples}

Blanks shall be analyzed to check for instrument and container contamination. A method blank shall be concurrently prepared and analyzed for each analytical batch. A minimum of one method blank shall be analyzed with each 20 samples.

\section{B.4.1.3.3 Duplicate Samples}

Duplicate results will be obtained and used to calculate precision. One in 20 samples shall be counted twice to provide precision data.

\section{B.4.2 Data Precision, Accuracy, and Completeness}

Quality control sample results are used to evaluate laboratory and field precision and accuracy. Precision shall be determined by comparing the concentrations of the various constituents between duplicate analyses. Accuracy shall be determined by comparing analytical results with the known (true) value of a reference standard (i.e., a laboratory control sample). The analytical accuracy for the spiked samples must be within the accepted accuracy of the method of analysis for the analyte of interest. Sample results falling outside of acceptable ranges for precision and accuracy shall be brought to the attention of laboratory management for evaluation and corrective action(s), as needed. 
Completeness shall be determined by comparing the amount of valid data obtained from a measurement system to the amount that was expected to be obtained. Data precision, accuracy, and completeness requirements shall be dependant on the end use of the data and determined during the DQO process for each site.

Laboratory results shall be checked upon receipt. If there appears to be an error in the analysis, the laboratory shall be contacted immediately, and corrective action(s) must be taken. If investigation reveals that processes were not in control, corrective action(s) shall be taken, and the resulting data evaluated to determine any impacts.

\section{B.4.3 Corrective Action}

This section establishes the methods and responsibilities for identifying, reporting, controlling, and resolving conditions of nonconformance and conditions adverse to quality for activities performed in support of the New Mexico Sites work.

\section{B.4.3.1 Nonconformance}

A nonconformance is a deficiency in characteristic, documentation, or procedure that renders the quality of an item or activity as unacceptable, or indeterminate. The NV ERP policy encourages all personnel to identify and document nonconforming items and processes. It is also NV ERP policy to identify nonconformances in a manner that focuses on solutions and discourages fault-finding to encourage the open identification and resolution of problems. Individuals identifying nonconforming conditions or items are responsible for documenting and reporting the nonconformance. Responsible personnel should be notified at the time the nonconformance is identified so that, when possible, corrective measures may be taken immediately.

All NCRs shall be handled in accordance with each organization's internal processes. An NCR shall specify:

\section{- Originator}

- Date of the nonconformance

- NCR number (unique)

- Responsible organization

- Requirement(s) 
- Nature of the nonconformance

- Disposition

- Technical justification for disposition

When an NCR affects cost, schedule, scope, or is a health and safety issue, the applicable NV ERP Project Manager and the NV ERP QAC and Health and Safety Representatives must be notified.

\section{B.4.3.2 Cause Analysis}

A root cause is the most basic element that, if corrected, will prevent recurrence of the same (or similar) problem. Cause analysis should be used where the understanding of the basic underlying cause is important to the prevention of similar or related problems. The cause analysis should be used to gain an understanding of the deficiency, its causes, and the necessary corrective actions to prevent recurrence. The level of effort expended should be based on the possible negative consequences of a repeat occurrence of a problem. The term "root cause" is used generally and does not require the use of highly sophisticated methods such as is used for accidents.

\section{B.4.3.3 Trend Analysis}

Trend analyses should be performed on nonconforming conditions, deficiencies, root causes, and the results of improvement initiatives to identify any possible trends. Adverse trends shall be brought to the attention of the appropriate management. Positive trends, such as improved performance or cost savings resulting from enhancements or the application of new technology, should be shared to facilitate improvement in other areas or projects. As appropriate, information obtained from trend analyses should be included in a Lessons Learned system.

\section{B.4.3.4 Lessons Learned}

A Lessons Learned system has been established at DOE/NV as a focal point for reporting and retrieving important information concerning experiences gained through previous activities. Improvement can be fostered through incorporation of applicable Lessons Learned into work processes and project planning activities, including work plan development, budget development, and strategic planning. The Lessons Learned program should be used interactively with other management tools such as critiques, assessments, readiness reviews, and evaluations of field activities. 


\section{B.5.0 Criteria 4 - Documents and Records}

The New Mexico Sites shall have planning documents, as deemed necessary, for the work to be performed. Contractors may determine that additional procedures are necessary to further define the responsibilities and activities of specific scopes of work. Figure B.1-1 is a flowchart of the guidance documents.

\section{B.5.1 Documents and Records}

Systems and controls shall be implemented by project participants for identifying, preparing, reviewing, approving, revising, collecting, indexing, filing, storing, maintaining, retrieving, distributing, and disposing of pertinent quality documentation and records.

\section{B.5.1.1 Document Review and Control}

Plans and reports shall be reviewed for quality requirements, technical adequacy, completeness, and accuracy prior to their approval and issuance. The NV ERP documents shall be reviewed in accordance with the DOE/NV procedure AMEM-02-002, Document Review and Coordination (DOE/NV, 1999a).

A system or process for identifying documents that require control and controlling those documents shall be implemented to ensure that the latest revision of a document is used. The New Mexico Sites management is responsible for ensuring that personnel who perform work are in possession of the most current version of the documents applicable to the activities being conducted.

Revisions to controlled documents shall be approved by the same level of authority or organization as the original. Documents no longer in use should have their status clearly indicated, and record copies should be maintained in accordance with DOE Order 200.1, Information Management Program (DOE, 1996a).

\section{B.5.1.2 Change Control}

Changes or modifications to approved procedures or plans may be necessary to adjust an activity to actual field conditions or to revise programmatic methods of implementing project requirements. 
New Mexico Sites participants shall ensure that changes are properly identified, documented, approved, and controlled in accordance with the individual procedures of each participant organization. Verbal authorization of changes are permitted but must be documented and followed up with a written change notice in a timely manner. Changes shall be approved commensurate with the original document prior to implementation of the change. Changes to the SSHASP shall be in accordance with the participants applicable procedures. The DOE/NV Project Manager shall be notified of changes that impact the technical scope, cost, or schedule of the project.

\section{B.5.1.3 Records Maintenance}

Sufficient records of New Mexico Sites activities shall be prepared, reviewed, and maintained. Project records shall be maintained in accordance with DOE Order 200.1 (DOE, 1996a), Information Management Program. Contractors and other agency participants shall have a system in place for the storage and retrieval of quality records that is consistent with environmental regulations and DOE Order 200.1 (DOE, 1996a). 


\section{B.6.0 Criteria 5 - Work Processes}

The performance of activities shall be based upon the objectives of the project. Details of specific, environmental, data-collection activities will be discussed in the applicable site-specific planning documents. Appropriate technical methods or a scientific rationale shall be employed. Activities shall be performed in accordance with approved procedures and site-specific plans that comply with the applicable requirements of DOE Orders, procedures, and project planning documents. Upon request, contractors and participating organizations shall supply the DOE/NV with copies of applicable procedures. Deviations from the applicable approved project plans and procedures shall be approved and documented.

\section{B.6.1 Evaluation and Use of Existing and New Data}

Existing and new data shall be evaluated against current requirements for their intended use. This analysis consists of editing, screening, checking, auditing, verification, and review. Methods shall be in place for the control and transfer of data, control of interpretive work products, and the control of data within a database. The process should provide guidance for gathering, manipulating, and distributing data. The quality of existing data shall be determined, based on the traceability of data and the level of QA/QC applied to the data during initial collection, prior to inclusion into a central database. Reports or interpretative works shall indicate the quality of the data being used. Prior to use, newly acquired analytical data will be evaluated against predetermined objectives and criteria.

\section{B.6.2 Computer Hardware and Software}

Computer hardware/software configurations are defined as the combination of computer program software version, operating software version, and model of computer hardware. Computer software and hardware/software configurations used in the acquisition, modeling or storage of environmental data shall be installed, tested, used, maintained, controlled, and documented to meet the requirements of the user and/or data management criteria. Compatibility between software and hardware systems must be achieved for long-term retrievability. To the extent possible, contractor's and project participant's hardware and software should be compatible with that of the NV ERP. 


\section{B.6.2.1 Computer Systems}

Computer hardware/software configurations for the storage and manipulation of environmental data should be tested by knowledgeable individuals prior to actual use and the results documented and maintained. Changes to hardware/software configurations should be assessed to determine the impact of the change on the technical and quality objectives of the environmental program. If any of the components are changed or modified and a new configuration results, or if program requirements change so that the capability of the hardware/software configurations to meet the new requirements is uncertain, then the configuration should be retested and redocumented.

Computer hardware/software configurations integral to measurement and testing equipment (M\&TE) that are calibrated for specific uses do not require further testing unless the software uses change or the configuration is modified.

The physical media on which software is stored shall be controlled and protected so that software and data are physically retrievable and protected from loss or compromise by catastrophic events. Back-up copies shall be maintained so that a single event will not cause a significant loss of software or data.

\section{B.6.2.2 Software Design/Development}

Project participants involved in the development or use of major-use software for modeling or technical computations will develop and implement processes for the development, modification, verification/validation, and control of computer software codes. Code criteria should be clearly defined prior to development or purchase and should be consistent with applicable national standards. Software will be qualified for use, based on its ability to provide acceptable results for its intended application. The configuration of software should be controlled and documented so traceability is maintained through the developmental history. Documentation of the development or modification of software codes must include the appropriate peer reviews and verification/validation. 


\section{B.6.2.2.1 Code Evaluation}

Newly developed computer codes or modifications to existing software shall be reviewed and the reviews documented by individuals who are knowledgeable in the area of code development. Reviewers should consider the following aspects:

- Assumptions are reasonable and valid

- Correctness of the mathematical model

- Conformance of methods to accepted and published concepts (recognizing that alternative methods and interpretations other than those of the evaluators may be acceptable)

- Consistency of results with known data

- Reasonable and prudent use of data and analysis tools

- Appropriateness for intended purpose

\section{B.6.2.2.2 Code Verification/Validation}

Software should be qualified for use based on its ability to provide acceptable results for the intended application. Software verification and validation activities will include provisions for providing confidence that the software adequately and correctly performs all intended functions. The extent of verification/validation required shall depend on the complexity, risk, and uniqueness of the code. Computer software code modifications shall be verified and validated according to the same requirements as the original code. Verification of changes may be limited to the scope of the modification, if the rest of the code is not affected. Acquired technical software used without modification must have operational checks performed through test cases to verify that the software is functioning as intended.

Computer applications, project participants, used for the evaluation of historical data maintained or transferred via electronic media shall have QC checks performed as appropriate to the application being used. These checks must be documented and maintained in project files. 


\section{B.6.2.2.3 Software Documentation}

All developed or procured computer codes shall be uniquely identified. Computer software code documentation shall be maintained with associated calculations and reference material.

Documentation will consist of software design and reference material, verification/validation records, operational test records, and user-oriented information.

\section{B.6.2.3 Peer Review of Software and Code Applications}

The peer review is an assessment of the assumptions, calculations, extrapolations, alternate interpretations, methodology, acceptance criteria, and conclusions pertaining to interpretive work products generated through use of computer software. Peer reviews shall be performed and documented to ensure that interpretive work products are technically adequate, properly documented, and satisfy established technical and quality requirements. Peer reviewers shall possess the appropriate subject matter/technical expertise and not have participated in preparing the original work. All review comments and the attendant comment responses shall be recorded on review sheets and maintained in the project files. The acceptable level of accuracy of each interpretive work product should be established by project management.

\section{B.6.3 Field Investigation}

Field activities generally involve the collection of data for the purpose of decision making. Field data acquisition shall be accomplished through the use of approved plans, procedures and/or instructions, by qualified personnel, using appropriate tools and calibrated equipment. Additionally, all work shall be performed safely within the controls established to prevent/mitigate hazards. Details of specific environmental data collection activities shall be delineated in the associated project plans and instructions. Data acquisition methods for which a procedure does not exist (those that are unique, experimental, or under development) shall be detailed in the project-specific plans or instructions. 


\section{B.6.3.1 Sample Custody}

Chain of custody for each field sample collected must be documented to provide the traceability of possession from the time the samples are collected until disposal. A sample is considered to be in custody if it meets any of the following criteria:

- Is in a person's actual possession

- Is in a person's unobstructed view after being in the person's physical possession

- Is in a secured area to prevent tampering after having been in the person's physical possession

- Is in a designated secured area, restricted to authorized personnel only

Sampling events shall be monitored to ensure that custody procedures and records are being properly implemented. Without exception, sample custody shall be continuously maintained for all samples collected.

\section{B.6.3.1.1 Chain of Custody Form}

Each individual who possesses a sample is responsible for sample custody until the sample is relinquished to another individual or a secure storage area via the chain of custody form. Field teams shall initiate chain-of-custody forms for samples collected during field activities in accordance with written and approved procedures and/or instruction. Whenever samples are transferred to a new sample custodian, the new custodian shall sign his or her name, the company name, and note the time and date that the transfer occurred. There shall be no gaps on the record of custody. The chain of custody form shall accompany the samples during handling and shipment, and it shall chronicle the history of custody.

\section{B.6.3.1.2 Custody Seals}

To ensure that tampering is easily detectable, each sample container shall be individually sealed with a custody seal. The seal shall be placed over or around the lid of the sample container so that the container cannot be opened without breaking the seal. Each custody seal shall be initialed and dated by the sample custodian. 


\section{B.6.3.1.3 Sample Labels and Identification}

Sample labels shall contain the unique sample numbers and other sampling information. This information must be entered using indelible ink and the label securely affixed to the container. All information and data for a sample are keyed to each sample's unique number. The sample label shall contain the following required information:

- Project name

- Unique sample number

- Sampling date and time (military)

- Sample location and depth interval (if applicable)

- Sample medium

- Requested analyses

- Name of the individual collecting the sample

- Preservation or conditioning of the sample

Each sample number shall be indicated on both the container and field data/sample collection forms. For samples requiring multiple containers, the same sample identification numbers shall be required on each container. Labels that are not plastic coated and have the potential to smear or deteriorate shall be covered with clear tape.

\section{B.6.3.1.4 Sample Handling, Preservation, Packaging, and Shipping}

Proper sample handling is achieved by selecting the appropriate sample containers, preservation procedures, and holding times for specific analyses. Where applicable, sample containers shall be certified clean per EPA protocol and shall remain sealed until ready for use. Certificates of container cleanliness shall be maintained in the project files. A table of parameters and analytical methods is provided in Attachment 2.

Upon completion of sampling, labeling, and custody sealing, each sample shall be placed in a separate, sealable plastic bag; transferred to an appropriate shipping container cooled with ice $4^{\circ} \mathrm{C}\left( \pm 2^{\circ} \mathrm{C}\right)$, if required; and protected from breakage by using shock-absorbent packing material. Approved procedures must comply with Title 49 CFR, Parts 170 to 180 (CFR, 1999) for the packaging, labeling/placarding, and shipping of samples. 


\section{B.6.3.1.5 Decontamination}

To prevent cross-contamination of samples, equipment coming in contact with samples shall be decontaminated prior to use, between sampling locations, and before leaving the site. Certification of cleanliness shall be obtained for disposable or precleaned sampling equipment, if they are not decontaminated by the sampling organization. Decontamination activities shall be performed and documented in accordance with the participating organization's approved written procedures.

Equipment rinsate blanks shall be submitted to the analytical laboratory to assess the effectiveness of the decontamination process. If the rinsate blank results indicate possible contamination, corrective actions shall be implemented to preclude recurrence. Sample results obtained using the suspect sampling equipment shall be reviewed to determine whether analytical qualifiers should be assigned to the data.

\section{B.6.3.1.6 Investigation-Derived Waste}

Investigation-derived waste (IDW) shall be containerized pending the results of waste characterization. To ensure compliance with DOE requirements and federal and state regulations, IDW shall be characterized and disposed of in accordance with approved plans.

\section{B.6.3.1.7 Field Documentation}

Field documentation should be of sufficient detail to facilitate the reconstruction of field activities. Field personnel shall document activities on a logbook or on the appropriate form as required by each contractor doing work for the New Mexico Sites. Documentation should be made in indelible ink and include all information applicable to the activity being performed.

Field-generated records shall be independently reviewed to verify they are complete and accurate. This review should be noted on the reviewed document with an initial and date. Records shall be preserved and maintained in accordance with Section B.5.1.3.

\section{B.6.3.1.8 Photographic Documentation}

With the approval of the DOE/NV Project Manager, photographs may be taken during the corrective action investigation and/or corrective action activities. Photographs shall be documented on a 
photographic log in accordance with contractor procedures. The photographs and negatives shall be processed and stored in accordance with DOE/NV security procedures and National Archives and Records Administration regulations.

\section{B.6.3.2 Identification and Control of Items}

The New Mexico Sites participants shall establish and document sufficient controls to ensure that quality-affecting items, such as equipment, components, and material can be readily identified. These controls shall be established to prevent incorrect use, to retain integrity of materials, and to preserve the desired operating characteristics of equipment. Controls shall be applied that are based on the risk to the project if control of the item is lost. Appropriate controls shall be applied prior to and subsequent to use. Specific requirements for preservation and packaging shall be identified in project documents.

Hazardous materials shall be properly controlled and transported in accordance with Title 49 CFR Part 171-180, Transportation - Hazardous Materials Shipping Regulations (CFR, 1999).

\section{B.6.3.3 Calibration and Preventive Maintenance}

The M\&TE used at the New Mexico Sites shall be uniquely identified and controlled. A system of calibration and preventive maintenance shall be employed by project participants to ensure the proper operation of M\&TE. Reference standards of the correct type, range, and acceptable uncertainty shall be used for collecting data consistent with the project objectives.

\section{B.6.3.3.1 Calibration}

Approved procedures or the manufacturer's recommendations shall be used to calibrate M\&TE prior to use and at prescribed intervals thereafter. The frequency of calibrations (periodic or factory) shall be based on the manufacturer's recommendations, national standards of practice, equipment type and characteristics, and past experience. Operational, or in-house, calibrations and/or source-response checks shall be performed on the appropriate M\&TE prior to the start of work and at prescribed intervals to verify the equipment's continued accuracy and operational function. 
Equipment for which the periodic calibration period has expired, equipment that fails calibration, or equipment that becomes inoperable shall be tagged "out-of-service" and, when possible, segregated to prevent inadvertent use. Results of activities performed using equipment that is out of calibration shall be evaluated for adverse affects and the appropriate personnel notified.

Physical and chemical standards shall have certifications traceable to National Institute of Standards and Technology, EPA, or other nationally recognized agencies. Supporting documentation on all reference standards and equipment shall be maintained.

\section{B.6.3.3.2 Preventive Maintenance}

Preventive maintenance shall be performed to maintain performance and reliability, prevent equipment from failing during use, and to identify sources for repair replacement. Preventive maintenance programs shall include all sensitive equipment.

Field equipment preventive maintenance programs will provide the following as applicable:

- A listing of the equipment included in the program

- The frequency of maintenance considering manufacturer's recommendations and/or previous experience with the equipment

- A list of spare parts to be maintained

- Activities to be performed in the event of equipment failure (i.e., spare parts maintained, back-up instrumentation, or sources to repair or replace instrumentation)

\section{B.6.3.4 Laboratory Operation}

Laboratories performing analytical work for the New Mexico Sites must operate in accordance with an acceptable written QA program. Plans and procedures relevant to the New Mexico Sites work must be made available upon request. Deviations from approved procedures shall be documented.

All New Mexico Sites participants who subcontract analytical services must ensure quality of services through established procurement practices and oversight activities. Laboratories must participate in an Interlaboratory Performance Evaluation program appropriate to sample types and 
analyses. The laboratory must provide the results of these performance evaluation studies along with the laboratory's response to any deficiencies which were identified upon request.

\section{B.6.3.4.1 Preanalysis Storage}

Samples received at the analytical laboratory that have been entered into the sample tracking system shall be placed into a storage refrigerator or secure storage area until analyzed. The methods of storage are generally intended to:

- Retard biological action

- Retard hydrolysis of chemical compounds and complexes

- Reduce volatility of constituents

- Reduce adsorption effects

- Reduce light exposure

Preservation methods are generally limited to $\mathrm{pH}$ control, preservative addition, and refrigeration. Preanalysis sample storage procedures shall be documented and described in laboratory-specific procedures.

\section{B.6.3.4.2 Post-Analysis Storage}

The possibility of reanalysis requires that proper environmental control for post-analysis samples be provided. These controls shall be described in laboratory-specific procedures. The samples shall be properly disposed of by the laboratory unless other arrangements have been made to return them to the site. The laboratory must contact the participants designated personnel prior to disposal of samples.

\section{B.6.4 Analytical Data Usability}

Analytical data received for input into a project shall be assessed for acceptability against the requirements stipulated in the applicable project document. Personnel should verify that analytical data reports have been reviewed by appropriate individuals other than those generating the analytical data or the report, and that all forms of the report (printed or electronic) carry a notice of any limitations on the use of the data. 


\section{B.6.4.1 Data Management}

Analytical data shall be controlled and managed to guarantee data integrity throughout acquisition and development. Systems must be established for directing analytical data results into a controlled data management system. Requirements shall be established for identification, collection, selection, control, and transfer of analytical data both within and external to the NV ERP data management system. Analytical data that are submitted shall be qualified and traceable to original data records and procedures established for processing, storage, and control of data. Analytical data users are responsible for determining if the data are sufficient for their intended use.

Each participating organization responsible for generating environmental data for the New Mexico Sites shall have a management plan for handling data that describes the flow of data from its generation through its final use and storage. The Data Management Plan shall include or reference the specific procedures to be used for data verification and validation to ensure that all data used to support decisions made for the New Mexico Sites are of known and documented quality. Procedures shall be used to optimize the detection and correction of errors and prevent data loss during data reduction, reporting, and data entry into databases.

\section{B.6.4.2 Evaluation and Use of Data}

Participating organizations shall have a system in place for the control and transfer of data and interpretive work products to the NV ERP Common Data Repository, and provide guidance for gathering, manipulating, and distributing data. The quality of existing data shall be determined, based on the traceability of data and the level of QA/QC applied to the data during initial collection and current requirements for their intended use. This analysis consists of editing, screening, checking, auditing, verification, and review. Reports, models, or interpretative works shall indicate the quality of the data being used. Prior to use, newly acquired analytical data will be evaluated against predetermined objectives and criteria. Computer applications used for the evaluation of data maintained or transferred via electronic media shall have quality control checks performed as appropriate to the application being used. 


\section{B.6.4.3 Data Reduction, Verification, and Validation}

Computations performed on raw data are considered data reductions. Numerical reduction of field and analytical data shall be formally checked in accordance with approved procedures, and this checking must be performed prior to the presentation of results. If unchecked results are to be presented, transmittals or subsequent calculations based on these results must be marked "preliminary" until the results are checked and determined to be correct.

Verification is the process of checking and reviewing the data reduction process. Data verification is a systematic review of data by qualified individuals to check data reduction and ensure that data meet specified guidelines.

Validation of analytical data is a comprehensive verification which includes complete review of raw data. The site-specific DQO process shall establish what percentage of analytical data packages shall be validated. Qualifiers may be attached to the data to indicate the results of the verification process. These qualifiers may restrict or limit certain uses of the data.

\section{B.6.4.3.1 Data Completeness Review}

A completeness review should be conducted to ensure that field and laboratory data and documentation are present and complete. During this review, problems should be identified and documented. Information from this review should accompany the data. The review should include the verification that:

- Overall deliverable objectives are met.

- Laboratory documentation is complete and accurate.

- Significant problems are identified in laboratory documentation.

- Chain of custody documents are complete and contain required information.

- Analytical practices are consistent with chain of custody requirements.

- Analytical information presented is correct and complete.

- Analytical practices are within technical guidelines.

- All field forms are present and complete.

\section{B.6.4.3.2 Data Review and Summary}

Selected QC checks and procedures shall be evaluated for compliance or noncompliance with DQO standards. Deficiencies in the data package shall be communicated to the laboratory, and additions or 
corrections to the data package shall be controlled. Data review shall be conducted by personnel with training in, and a technical understanding of, laboratory methods and data quality. Data review shall include, but not be limited to, the examination of the following:

- Analytical requirements have been met.

- Critical items meet the project requirements.

- Analytical method QC compliance evaluated and applied to results/qualifiers.

- Sample data quality indicator goals are evaluated.

- Surrogate data quality indicators are evaluated.

- Laboratory QC sample data quality indicators are evaluated.

- Calibration information evaluated and applied to results/qualifiers.

- Internal standard evaluated and applied to results/qualifiers.

- Serial dilution effects evaluated.

- Holding time criteria has been met.

- Laboratory data qualifiers are correct and explained or a key is included.

- Compound analyte concentration is accurate.

- Sample collection and storage requirements are met.

\section{B.6.4.3.3 Data Validation}

Data validation encompasses a complete validation of the analytical results according to EPA functional guidelines or an equivalent industry-standard protocol. Data validation and review of Contract Laboratory Program (CLP) and CLP-like data packages shall be performed in accordance with the USEPA Contract Laboratory Program, National Functional Guidelines for Inorganic Data Review (EPA, 1994b) and Contract Laboratory Program, National Function Guidelines for Organic Data Review (EPA, 1999) or a national standard. This review is designed to be conducted by personnel with training in, and a technical understanding of, laboratory methods and data quality, and with the extensive experience required of professionally trained data validators. Calculations of results from raw data will be verified, and data validation qualifiers will be assigned. The results of this review and a summary of parameter detections shall be forwarded to the appropriate project manager.

Data validation shall include a check of the calculation of all QC sample results and a third party confirmation of a minimum of five percent, based on direction from the DOE/NV Radioactive Waste Acceptance Program, of the sample result calculations from characterization samples or samples intended to demonstrate that the contaminant(s) of concern have been isolated, stabilized, and/or 
removed. Data validation shall also include a check of all the functional guideline parameters included in lower level reviews.

The percentage of data packages to be validated for the New Mexico Sites shall be dependent on the end use of the data and established during the site-specific DQO process. Sample results selected for validation shall be determined by use of a random number generator or may be selected by project management in cases where special criteria exist. The DOE/NV New Mexico Sites Task Manager shall maintain the option of having additional validation performed.

\section{B.6.4.4 Laboratory Data Reporting}

Analytical data reports must contain, at a minimum, the following information:

- Cover page with the reviewer's signature, data qualifiers, and a description of any technical difficulties encountered during the analyses

- Date the sample was received

- Date the sample was prepared

- Date the sample was analyzed

- Sample identification number

- Laboratory sample identification number

- Analytical method reference number

- Analytical results

- Tabulated QC sample results

- Instrument tuning and calibration results

- Final copy of the chain of custody form, with appropriate signatures

- Hard copy raw data of calibration, QC samples, and the analyses of field samples

Data packages shall be required for all analytical results unless sample results are excluded from data validation by DOE/NV project management. Validated data shall be reviewed to determine whether 
they meet the DQOs of the investigation. The data shall be reviewed to ensure that the required number of samples were collected, critical samples were collected and analyzed, and the results passed data-validation criteria. The data shall also be reviewed to determine whether detection limits were met. Data-reporting techniques shall be in accordance with the project data-reporting requirements; data-reporting procedures should be consistent with those found in the User's Guide to the Contract Laboratory Program (EPA, 2000).

\section{B.6.4.4.1 Data Reporting}

Data shall be reported in accordance with standardized formats. Electronic data transfers shall be delivered, along with the hard copy, on 3.5-inch diskettes or other methods agreed upon with the NV ERP Common Data Repository custodial organization. The laboratory data will not be loaded into the common data repositories for general use until it has been verified/validated. 


\section{B.7.0 Criteria 6 - Design}

Any quality-affecting items or processes designed in support of the New Mexico Sites shall be in accordance with a documented design control process and based on sound engineering and scientific principles using the appropriate standards. The acceptability and adequacy of the design product shall be verified or validated by a qualified individual(s) other than those who performed the original design. Verification and validation shall be completed prior to approval and implementation of the design. Design records shall include the design steps and sources of input that support the final output. The final design output shall be approved in accordance with the participants' internal procedures. Changes or modifications to the final design shall be subject to the same control measures and approvals as applied to the original design. 


\section{B.8.0 Criteria 7 - Procurement}

Procurement of items and services for the New Mexico Sites shall be consistent with standard commercial purchase order terms and conditions, and performed in cooperation with the DOE/NV Contracts Management Division. Project participants must have processes in place that meet the requirements of their contracts or agreements and applicable federal requirements.

\section{B.8.1 Procurement Control}

Items and services of a technical nature procured in support of the New Mexico Sites shall be of a quality that meets the requirements of the project. Project participants shall establish controls to ensure that, as a minimum, procured items and services meet specifications delineated in the procurement documents. Each participating organization shall have systems in place to track items and confirm the delivery of procured items and services as specified. Project participants shall have a program in place, invoking the appropriate quality requirements of the contractor's QA program and specifying any project requirements for the procurement of items and services.

Subcontractors procured for New Mexico Sites activities must be evaluated for prior experience, ability to perform specific tasks, and cost. The capabilities of subcontractor personnel shall be assessed by the procuring contractor to verify qualifications and determine the type and amount of training and supervision needed for environmental restoration activities.

\section{B.8.1.1 Procurement Documents}

Procurement documents for the New Mexico Sites shall define the scope of work for the item or service being procured and provide specifications, acceptance criteria, shipping and handling requirements, health and safety requirements, and any documentation required, as applicable. Technical specifications shall either be directly included in the procurement documents or included by reference to specific drawings, specifications, procedures, regulations, or codes that describe the items or services to be furnished. Procurement documents shall be reviewed for accuracy and completeness by qualified personnel prior to initial issue. Changes to a procurement document require the same level of review and approval as the original document. 


\section{B.8.1.2 Measurement and Testing Equipment}

Procurement documents shall also require that all purchased and rented M\&TE be calibrated to existing national standards prior to acceptance and that calibration documentation is provided. Calibration certification and instrument manufacturer's manuals should be available in project files for M\&TE. Schedules for recalibration shall be established and implemented for M\&TE requiring periodic calibration.

\section{B.8.1.3 Verification of Quality Conformance}

If applicable, procurement documents for New Mexico Sites-related items or services shall require access to the subcontractor's or vendor's facilities, including their subtier facilities, work areas, and records for assessments to verify acceptability. Upon delivery, procured items or services shall be inspected for conformance to procurement specifications and requirements prior to using items or placing them in service. Project personnel have the authority to stop work if significant quality problems are identified. Procured items should be evaluated for suspect/counterfeit parts. If there are indications that suppliers knowingly supplied substandard items or services, the DOE Office of Inspector General shall be notified. 


\section{B.9.0 Criteria 8 - Inspection and Acceptance Testing}

Inspections and acceptance testing shall be accomplished for specific items in accordance with approved inspection documents and test procedures that reflect acceptance and performance criteria. Individuals performing inspections and acceptance testing shall be independent of those who performed the work. Quality-affecting materials used during characterization, corrective action, or sampling activities shall be inspected upon receipt for adequacy. The M\&TE used in the performance of inspections or acceptance tests shall be calibrated and properly maintained. Any item or work determined to be defective shall be controlled to avoid inadvertent use. 


\section{B.10.0 Criteria 9 - Management Assessment}

Planned and periodic assessments shall be conducted and shall involve the participation of project management. The primary emphasis of management assessments is to evaluate the implementation of the integrated QA program and identify problems that hinder the achievement of objectives. Contractor management should conduct periodic assessments that focus on such issues as the:

- Adequacy of implementation of the integrated QA program, with particular emphasis on quality improvement

- Existence of any management biases or organizational barriers that impede the improvement process

- Adequacy of the appraised organization's structure, staffing, and physical facilities

- Existence of effective training programs

The results of the assessment shall be documented in a final report and issued to the appropriate personnel. Management has the primary responsibility to ensure the timely follow-up of corrective actions, including an evaluation of the effectiveness of management's actions. Results of the management assessment should be entered into a tracking system for the purposes of identifying trends and lessons learned. 


\section{B.11.0 Criteria 10 - Independent Assessments}

Independent management and technical assessments shall be performed to verify compliance with applicable quality requirements, DOE policies, and procedures. Assessments shall be conducted to measure item and service quality, the adequacy of work performance, and to promote improvement. The scheduling of the assessments and resource allocation for independent assessments should be based on the status, risk, and complexity of work being assessed.

The group performing the independent assessment shall be composed of individuals that are not directly involved in the work being assessed. Each group performing independent assessments shall have sufficient authority and freedom to carry out the activities necessary to effectively conduct the assessment. Assessments should focus on improving the quality of the processes that lead to the end product.

Results of each assessment should be tracked and resolved by responsible management with follow-up of deficient areas. Assessment responses should include: corrective action, identification of the root cause, actions to prevent recurrence, and actions for improvement. 


\section{B.12.0 References}

American Society of Quality Control. 1994. American National Standard Institute, Specifications and Guidelines for Quality Systems for Environmental Technology Programs, ANSI/ASQ E-4. Milwaukee, WI.

ASQC, see American Society of Quality Control.

CFR, see Code of Federal Regulations.

Code of Federal Regulations. 1996. Title 10, Part 830.120, "Quality Assurance Requirements." Washington, DC.

Code of Federal Regulations. 1998a. Title 10 Part 71, "Energy - Packaging and Transportation of Radioactive Material." Washington, DC.

Code of Federal Regulations. 1998b. Title 29 Part 1910.120, "Hazardous Waste Operations and Emergency Response." Washington, DC.

Code of Federal Regulations. 1999. Title 49, Parts 170 through 180, "Transportation - Hazardous Materials Shipping Regulations." Washington, DC.

DOE, see U.S. Department of Energy.

DOE/NV, see U.S. Department of Energy, Nevada Operations Office.

EPA, see U.S. Environmental Protection Agency.

U.S. Department of Energy. 1990. Requirements for Quality Control of Analytical Data. Washington, DC.

U.S. Department of Energy. 1996a. Information Management Program, DOE Order 200.1. Washington, DC.

U.S. Department of Energy. 1996b. Safety Management System Policy, DOE Order 450.4. Washington, DC.

U.S. Department of Energy. 1998. Worker Protection Management for DOE Federal and Contractor Employees, DOE Order 440.1A. Washington, DC.

U.S. Department of Energy. 1999. Quality Assurance, DOE Order 414.1A. Washington, DC. 
U.S. Department of Energy, Nevada Operations Office. 1993. DOE/NV Quality Glossary. Las Vegas, NV.

U.S. Department of Energy, Nevada Operations Office. 1999a. Document Review and Coordination, AMEM-02-002, Rev. 0. Contained in Policies, Plans, Procedures, and Guidance Manual. Las Vegas, NV: Office of the Assistant Manager for Environmental Management.

U.S. Department of Energy, Nevada Operations Office. 1999b. Nevada Test Site Waste Acceptance Criteria, NTSWAC, DOE/NV-325, Rev. 2. Las Vegas, NV.

U.S. Environmental Protection Agency. 1994a. Guidance for the Data Quality Objectives Process, EPA QA-G-4. Washington, DC.

U.S. Environmental Protection Agency. 1994b. USEPA Contract Laboratory Program National Functional Guidelines for Inorganic Data Review, EPA-540/R-94/013. Washington, DC.

U.S. Environmental Protection Agency. 1998. Guidance for Quality Assurance Project Plans, EPA QA-G-5, EPA/600/R-98/018. Washington, DC.

U.S. Environmental Protection Agency. 1999. USEPA Contract Laboratory Program National Functional Guidelines for Organic Data Review, EPA-540/R-99/008. Washington, DC.

U.S. Environmental Protection Agency. 2000. User's Guide to the Contract Laboratory Program, EPA 540-R-99-004. Washington, DC. 


\section{B.13.0 Glossary}

\section{Acceptance Criteria}

Specific characteristics of an item, process, or service defined in codes, standards, or other requirement documents. (DOE/NV, 1993)

\section{Accuracy}

A measure of the closeness of an individual measurement or the average of a number of measurements to the true value. Accuracy includes a combination of random error (precision) and systematic error (bias) components that are due to sampling and analytical operations; the EPA recommends using the terms "precision" and bias," rather than "accuracy," to convey the information usually associated with accuracy. (EPA, 1998)

\section{Activity}

An all-inclusive term describing a specific set of operations or related tasks to be performed, either serially or in parallel (e.g., research and development, field sampling, analytical operations, equipment fabrication), that in total result in a product or service. (ASQC, 1994)

\section{Assessment}

The evaluation process used to measure the performance or effectiveness of a system and its elements. Assessment is an all-inclusive term used to denote any of the following: audit, performance evaluation, management systems review, peer review, inspection, or surveillance. (ASQC, 1994)

\section{Audit (Quality)}

A systematic and independent examination to determine whether quality activities and related results comply with planned arrangements and whether these arrangements are implemented effectively and are suitable to achieve objectives. (ASQC, 1994)

\section{Bias}

The systematic or persistent distortion of a measurement process which causes errors in one direction (i.e., the expected sample measurement is different from the sample's true value). (ASQC, 1994) 


\section{Calibration}

Comparison of a measurement standard, instrument, or item with a standard or instrument of higher accuracy to detect and quantify inaccuracies and to report or eliminate those inaccuracies by adjustments. (ASQC, 1994)

\section{Certification}

The act of determining, verifying, and attesting in writing to the qualifications of personnel, processes, procedures, or items in accordance with acceptance criteria. (DOE/NV, 1993)

\section{Characteristic}

Any property or attribute of a datum, item, process, or service that is distinct, describable, and/or measurable. (ASQC, 1994)

\section{Comparability}

A measure of the confidence with which one data set can be compared to another. (ASQC, 1994)

\section{Completeness}

A measure of the amount of valid data obtained from a measurement system compared to the amount that was expected to be obtained under correct, normal conditions. (ASQC, 1994)

\section{Condition Adverse to Quality}

An all-inclusive term used in reference to any of the following: failures, malfunctions, deficiencies, defective items or nonconformance. (DOE/NV, 1993)

\section{Corrective Action}

An action taken to eliminate the causes of an existing nonconformance, deficiency, or other undesirable situation in order to prevent recurrence. (ASQC, 1994)

\section{Criteria}

Rules or tests against which the quality of performance can be measured. They are most effective when expressed quantitatively. Fundamental criteria are contained in policies and objectives, as well as codes, standards, regulations, and recognized professional practices that DOE and DOE contractors are required to observe. (DOE/NV, 1993) 


\section{Data Quality Objectives (DQOs)}

Qualitative and quantitative statements derived from the DQO process that clarify study technical and quality objectives, define the appropriate types of data, and specify tolerable levels of potential decision errors that will be used as the basis for establishing the quality and quantity of data needed to support decisions. (ASQC, 1994)

\section{Data Quality Objectives Process}

A systematic strategic planning tool based on the scientific method that identifies and defines the type, quality, and quantity of data needed to satisfy a specific use. The key elements of the process include:

- Concisely defining the problem

- Identifying the decision to be made

- Identifying the key inputs to the decision

- Defining the boundaries of the study

- Developing the decision rule

- Specifying tolerable limits on potential decision errors

- Selecting the most resource efficient data collection design

Data quality objectives are the qualitative and quantitative outputs from the DQO process. The DQO process was developed originally by the EPA, but has been adapted for use by other organizations to meet their specific planning requirements. (ASQC, 1994)

\section{Data Usability}

The process of ensuring or determining whether the quality of the data produced meets the intended use of the data. (ASQC, 1994)

\section{Deficiency}

An unauthorized deviation from acceptable procedures or practices, or a defect in an item.

(ASQC, 1994)

\section{Design}

Specifications, drawings, design criteria, and performance requirements. Also the result of deliberate planning, analysis, mathematical manipulations, and design processes. (ASQC, 1994) 


\section{Document}

Any written or pictorial information describing, defining, specifying, reporting, or certifying activities, requirements, procedures, or results. (ASQC, 1994)

\section{Environmental Data}

Any measurements or information that describe environmental processes or conditions, or the performance of environmental technology. (ASQC, 1994)

\section{Environmental Data Operations}

Work performed to obtain, use, or report information pertaining to environmental processes and conditions. (ASQC, 1994)

\section{Graded Approach}

The process of basing the level of application of managerial controls applied to an item or work according to the intended use of the results and the degree of confidence needed in the quality of the results. (See data quality objectives process.) (ASQC, 1994)

\section{Independent Assessment}

An assessment performed by a qualified individual, group, or organization that is not a part of the organization directly performing and accountable for the work being assessed. (ASQC, 1994)

\section{Inspection}

An activity such as measuring, examining, testing, or gauging one or more characteristics of an entity and comparing the results with specified requirements in order to establish whether conformance is achieved for each characteristic. (ASQC, 1994)

\section{Item}

An all-inclusive term used in place of any of the following: appurtenance, facility, sample, assembly, component, equipment, material, module, part, product, structure, subassembly, subsystem, system, unit, documented concepts, or data. (ASQC, 1994) 


\section{Management Assessment}

The determination of the appropriateness, thoroughness, and effectiveness of management processes. (DOE/NV, 1993)

\section{Measurement and Testing Equipment (M\&TE)}

Tools, gauges, instruments, sampling devices or systems used to calibrate, measure, test, or inspect in order to control or acquire data to verify conformance to specified requirements. (ASQC, 1994)

\section{Method}

A body of procedures and techniques for performing an activity (e.g., sampling, chemical analysis, quantification) systematically presented in the order in which they are to be executed. (ASQC, 1994)

\section{Nonconformance}

A deficiency in characteristic, documentation, or procedure that renders the quality of an item or activity unacceptable or indeterminate; nonfulfillment of a specified requirement. (ASQC, 1994)

\section{Precision}

A measure of mutual agreement among individual measurements of the same property, usually under prescribed similar conditions, expressed generally in terms of the standard deviations. (ASQC, 1994)

\section{Procedure}

A specified way to perform an activity. (ASQC, 1994)

\section{Process}

Any activity or group of activities that takes an input, adds value to it, and provides an output to a customer. The logical organization or people, materials, energy, equipment, and procedures into work activities designed to produce a specified end result (work product). (DOE/NV, 1993)

\section{Quality}

The totality of features and characteristics of a product or service that bear on its ability to meet the stated or implied needs and expectations of the user. (ASQC, 1994) 


\section{Quality Assurance (QA)}

An integrated system of management activities involving planning, implementation assessment, reporting, and quality improvement to ensure that a process, item, or service is of the type and quality needed and expected by the customer. (ASQC, 1994)

\section{Quality Assurance Program}

The overall program (management system) established to assign responsibilities and authorities, define policies and requirements for the performance and assessment of work. (DOE, 1999)

\section{Quality Control $(Q C)$}

The overall system of technical activities that measures the attributes and performance of a process, item, or service against defined standards to verify that they meet the stated requirements established by the customer; operational techniques and activities that are used to fulfill requirements for quality. (ASQC, 1994)

\section{Quality Improvement}

A management program for improving the quality of operations. Such management programs generally entail a formal mechanism for encouraging work recommendations with timely management evaluation and feedback or implementation. (ASQC, 1994)

\section{Quality Indicators}

Measurable attributes of the attainment of the necessary quality for a particular environmental decision. Indicators of quality include precision, bias, completeness, representativeness, reproducibility, comparability, and statistical confidence. (ASQC, 1994)

\section{Quality System}

A structured and documented management system describing the policies, objectives, principles, organizational authority, responsibilities, accountability, and implementation plan of an organization for ensuring quality in its work processes, products (items), and services. The quality system provides the framework for planning, implementing, and assessing work performed by the organization and for carrying out required QA and QC. (ASQC, 1994) 


\section{Readiness Review}

A systematic, documented review of the readiness for startup or continued use of a facility, process, or activity. Readiness reviews are typically conducted before proceeding beyond project milestones and prior to institution of a major phase of work. (ASQC, 1994)

\section{Record}

A completed document that furnishes evidence relating to items or activities. (DOE/NV, 1993)

\section{Remediation}

The process of reducing the concentration of a contaminant (or contaminants) in air, water, or soil media to a level that poses an acceptable risk to human health. (ASQC, 1994)

\section{Representativeness}

A measure of the degree to which data accurately and precisely represent a characteristic of a population, parameter variations at a sampling point, a process condition, or an environmental condition. (ASQC, 1994)

\section{Risk}

A quantitative or qualitative expression of possible loss which considers both the probability that an event occurrence will cause harm or loss and the consequences of that event. (DOE/NV, 1993)

\section{Root Cause}

The most basic reason for conditions adverse to quality that, if corrected, will prevent occurrence or recurrence. (DOE/NV, 1993)

\section{Self Assessment}

Assessments of work conducted by individuals, groups, or organizations directly responsible for overseeing and/or performing the work. (ASQC, 1994)

\section{Service}

The result generated by activities at the interface between the supplier and the customer, and by supplier internal activities to meet customer needs. Such activities in environmental programs include design, inspection, laboratory and/or field analysis, repair, and installation. (ASQC, 1994) 


\section{Specification}

A document stating requirements and which refers to or includes drawings or other relevant documents. Specifications should indicate the means and the criteria for determining conformance. (ASQC, 1994)

\section{Standard Operating Procedure}

A written document that details the method for an operation, analysis, or action with thoroughly prescribed techniques and steps, and that is officially approved as the method for performing certain routine or repetitive tasks. (ASQC, 1994)

\section{Surveillance (Quality)}

Continual or frequent monitoring and verification of the status of an entity and the analysis of records to ensure that specified requirements are being fulfilled. (ASQC, 1994)

\section{Technical Review}

A documented critical review of work that has been performed within the state of the art. The review is accomplished by one or more qualified reviewers who are independent of those who performed the work, but are collectively equivalent in technical expertise to those who performed the original work. The review is an in-depth analysis and evaluation of documents, activities, material, data, or items that require technical verification or validation for applicability, correctness, adequacy, completeness, and assurance that established requirements are satisfied. (ASQC, 1994)

\section{Traceability}

The ability to trace the history, application, or location of an entity by means of recorded identifications. In a calibration sense, traceability relates measuring equipment to national or international standard, primary standards, basic physical constants or properties, or reference materials. In a data collection sense, it relates calculations and data generated throughout the project back to the requirements for quality for the project. (ASQC, 1994)

\section{Training}

The process of providing for and making available to an employee(s) and placing or enrolling an employee(s) in a planned, prepared, and coordinated program, course, curriculum, subject, system, or 
routine of instruction or education, in fiscal, administrative, management, individual development, or other fields which improve individual and organizational performance and assist in achieving the agency's mission and performance goals. (DOE/NV, 1993).

\section{Validation}

Confirmation by examination and provision of objective evidence that the particular requirements for a specific intended use are fulfilled. In design and development, validation concerns the process of examining a product or result to determine conformance to user needs. (ASQC, 1994)

\section{Verification}

Confirmation by examination and provision of objective evidence that specified requirements have been fulfilled. In design and development, verification concerns the process of examining a result of a given activity to determine conformance to the stated requirements for that activity. (ASQC, 1994) 


\section{Attachment 1}

\section{Quality Criteria for Site-Specific Documents}




\section{Site-Specific Quality Assurance Project Plans Requirements}

Site-specific planning documents must contain QA/QC requirements appropriate for the site and activities being performed. This attachment delineates the quality criteria that should be included in either the site-specific planning document or addressed in an appendix to the appropriate document.

- Quality Objectives and Criteria for Measurement Data: Describe the project quality objectives and performance criteria.

- $\quad$ Special Training Requirements/Certification: Identify and describe any specialized training or certification requirements and discuss how such training will be provided and how the necessary skills will be assured and documented.

- $\quad$ Required Documentation and Records: Define the information that must be included in the data report package and the reporting format. Identify documents (e.g., interim progress reports, final reports) that will be produced. Specify the final disposition of records including retention period.

- $\quad$ Sampling Process Design: Describe any experimental design or data collection design for the project and classify all measurements as critical or non-critical.

- $\quad$ Sampling Methods Requirements: Describe specific performance requirements for the method. Address what to do when a failure in the sampling occurs, who is responsible for the corrective action, and how the effectiveness of the corrective action shall be determined and documented.

- Laboratory Requirements: Identify volume requirements, preservative requirements, and holding times.

- Analytical Methods Requirements: Identify the analytical methods, waste disposal requirements (if any), and specific performance requirements for the method.

- Quality Control Requirements: Identify required measurement QC check for both the field and laboratory. State the frequency of analysis for each type of QC check.

- Instrument/Equipment Testing, Inspection, and Maintenance Requirements: Describe how inspections and acceptance testing of environmental sampling and measurement systems and their components will be performed and documented. 
- Reports to Management: Identify the frequency and distribution of reports issued to inform management of the status of the project.

- Reconciliation with Data Quality Objectives: Describe how the results obtained from the project or task will be reconciled with the requirements defined by the data user or decision maker. 


\section{Attachment 2}

\section{Laboratory Chemical, Toxicity Characteristic Leaching Procedure, and Radiochemistry Analytical Requirements for New Mexico Sites}




\section{Laboratory Chemical, Toxicity Characteristic Leaching Procedure, and Radiochemistry Analytical Requirements for New Mexico Sites}

(Page 1 of 7 )

\begin{tabular}{|c|c|c|c|c|c|c|}
\hline $\begin{array}{l}\text { Parameter or } \\
\text { Analyte }\end{array}$ & $\begin{array}{l}\text { Medium or } \\
\text { Matrix }\end{array}$ & $\begin{array}{l}\text { Analytical } \\
\text { Method }\end{array}$ & $\begin{array}{c}\text { Minimum } \\
\text { Reporting Limit }\end{array}$ & $\begin{array}{l}\text { Regulatory } \\
\text { Limit }\end{array}$ & $\begin{array}{c}\text { Relative } \\
\text { Percent } \\
\text { Difference } \\
\text { (RPD) }^{\mathrm{a}}\end{array}$ & $\begin{array}{c}\text { Percent } \\
\text { Recovery }(\% \mathrm{R})^{\mathrm{b}}\end{array}$ \\
\hline \multicolumn{7}{|c|}{ ORGANICS } \\
\hline \multirow{2}{*}{$\begin{array}{l}\text { Total Volatile Organic } \\
\text { Compounds (VOCs) }\end{array}$} & Water & \multirow{2}{*}{$\begin{array}{l}8260 \mathrm{~B}^{\mathrm{c}} \\
5030 \mathrm{~B}^{\mathrm{c}}\end{array}$} & \multirow{2}{*}{$\begin{array}{l}\text { Analyte-specific } \\
\text { estimated } \\
\text { quantitation limits }^{d}\end{array}$} & \multirow{2}{*}{$\begin{array}{l}\text { Not Applicable } \\
\text { (NA) }\end{array}$} & $14^{e}$ & $61-145^{e}$ \\
\hline & Soil & & & & $24^{e}$ & $59-172^{\mathrm{e}}$ \\
\hline \multicolumn{7}{|l|}{$\begin{array}{c}\text { Toxicity } \\
\text { Characteristic } \\
\text { Leaching Procedure } \\
\text { (TCLP) VOCs }\end{array}$} \\
\hline Benzene & \multirow{10}{*}{ Aqueous } & \multirow{10}{*}{$1311 / 8260 B^{c}$} & $0.050 \mathrm{mg} / \mathrm{L}^{d}$ & $0.5 \mathrm{mg} / \mathrm{L}^{d}$ & \multirow{10}{*}{$14^{e}$} & \multirow{10}{*}{$61-145^{\mathrm{e}}$} \\
\hline $\begin{array}{c}\text { Carbon } \\
\text { Tetrachloride }\end{array}$ & & & $0.050 \mathrm{mg} / \mathrm{L}^{\mathrm{d}}$ & $0.5 \mathrm{mg} / \mathrm{L}^{\mathrm{d}}$ & & \\
\hline Chlorobenzene & & & $0.050 \mathrm{mg} / \mathrm{L}^{\mathrm{d}}$ & $100 \mathrm{mg} / \mathrm{L}^{d}$ & & \\
\hline Chloroform & & & $0.050 \mathrm{mg} / \mathrm{L}^{\mathrm{d}}$ & $6 \mathrm{mg} / \mathrm{L}^{\mathrm{d}}$ & & \\
\hline 1,2-Dichloroethane & & & $0.050 \mathrm{mg} / \mathrm{L}^{\mathrm{d}}$ & $0.5 \mathrm{mg} / \mathrm{L}^{\mathrm{d}}$ & & \\
\hline 1,1-Dichloroethene & & & $0.050 \mathrm{mg} / \mathrm{L}^{d}$ & $0.7 \mathrm{mg} / \mathrm{L}^{\mathrm{d}}$ & & \\
\hline Methyl Ethyl Ketone & & & $0.050 \mathrm{mg} / \mathrm{L}^{\mathrm{d}}$ & $200 \mathrm{mg} / \mathrm{L}^{d}$ & & \\
\hline Tetrachloroethene & & & $0.050 \mathrm{mg} / \mathrm{L}^{\mathrm{d}}$ & $0.7 \mathrm{mg} / \mathrm{L}^{\mathrm{d}}$ & & \\
\hline Trichloroethene & & & $0.050 \mathrm{mg} / \mathrm{L}^{d}$ & $0.5 \mathrm{mg} / \mathrm{L}^{\mathrm{d}}$ & & \\
\hline Vinyl Chloride & & & $0.050 \mathrm{mg} / \mathrm{L}^{\mathrm{d}}$ & $0.2 \mathrm{mg} / \mathrm{L}^{\mathrm{d}}$ & & \\
\hline \multirow{2}{*}{$\begin{array}{l}\text { Total Semivolatile } \\
\text { Organic Compounds } \\
\text { (SVOCs) }\end{array}$} & Water & \multirow{2}{*}{$8270 C^{c}$} & \multirow{2}{*}{$\begin{array}{c}\text { Analyte-specific } \\
\text { estimated } \\
\text { quantitation limits }^{d}\end{array}$} & \multirow{2}{*}{ NA } & $50^{e}$ & $9-127^{e}$ \\
\hline & Soil & & & & $50^{\mathrm{e}}$ & $11-142^{\mathrm{e}}$ \\
\hline \multicolumn{7}{|l|}{ TCLP SVOCs } \\
\hline o-Cresol & \multirow{6}{*}{ Aqueous } & \multirow{6}{*}{$1311 / 8270 C^{c}$} & $0.10 \mathrm{mg} / \mathrm{L}^{\mathrm{d}}$ & $200 \mathrm{mg} / \mathrm{L}^{\mathrm{d}}$ & \multirow{6}{*}{$50^{e}$} & \multirow{6}{*}{$9-127^{e}$} \\
\hline m-Cresol & & & $0.10 \mathrm{mg} / \mathrm{L}^{\mathrm{d}}$ & $200 \mathrm{mg} / \mathrm{L}^{d}$ & & \\
\hline $\mathrm{p}$-Cresol & & & $0.10 \mathrm{mg} / \mathrm{L}^{\mathrm{d}}$ & $200 \mathrm{mg} / \mathrm{L}^{d}$ & & \\
\hline Cresol (total) & & & $0.30 \mathrm{mg} / \mathrm{L}^{\mathrm{d}}$ & $200 \mathrm{mg} / \mathrm{L}^{d}$ & & \\
\hline $\begin{array}{l}\text { 1,4-Dichloro- } \\
\text { benzene }\end{array}$ & & & $0.10 \mathrm{mg} / \mathrm{L}^{\mathrm{d}}$ & $7.5 \mathrm{mg} / \mathrm{L}^{\mathrm{d}}$ & & \\
\hline 2,4-Dinitrotoluene & & & $0.10 \mathrm{mg} / \mathrm{L}^{\mathrm{d}}$ & $0.13 \mathrm{mg} / \mathrm{L}^{\mathrm{d}}$ & & \\
\hline
\end{tabular}




\section{Laboratory Chemical, Toxicity Characteristic Leaching Procedure, and Radiochemistry Analytical Requirements for New Mexico Sites}

(Page 2 of 7 )

\begin{tabular}{|c|c|c|c|c|c|c|}
\hline $\begin{array}{c}\text { Parameter or } \\
\text { Analyte }\end{array}$ & $\begin{array}{l}\text { Medium or } \\
\text { Matrix }\end{array}$ & $\begin{array}{l}\text { Analytical } \\
\text { Method }\end{array}$ & $\begin{array}{c}\text { Minimum } \\
\text { Reporting Limit }\end{array}$ & $\begin{array}{l}\text { Regulatory } \\
\text { Limit }\end{array}$ & $\begin{array}{c}\text { Relative } \\
\text { Percent } \\
\text { Difference } \\
\text { (RPD) }^{\mathrm{a}}\end{array}$ & $\begin{array}{c}\text { Percent } \\
\text { Recovery }(\% R)^{b}\end{array}$ \\
\hline $\begin{array}{l}\text { Hexachloro- } \\
\text { benzene }\end{array}$ & \multirow{8}{*}{ Aqueous } & \multirow{8}{*}{$1311 / 8270 C^{c}$} & $0.10 \mathrm{mg} / \mathrm{L}^{\mathrm{d}}$ & $0.13 \mathrm{mg} / \mathrm{L}^{\mathrm{d}}$ & \multirow{8}{*}{$50^{e}$} & \multirow{8}{*}{$9-127^{e}$} \\
\hline $\begin{array}{l}\text { Hexachloro- } \\
\text { butadiene }\end{array}$ & & & $0.10 \mathrm{mg} / \mathrm{L}^{\mathrm{d}}$ & $0.5 \mathrm{mg} / \mathrm{L}^{\mathrm{d}}$ & & \\
\hline $\begin{array}{l}\text { Hexachloro- } \\
\text { ethane }\end{array}$ & & & $0.10 \mathrm{mg} / \mathrm{L}^{\mathrm{d}}$ & $3 \mathrm{mg} / \mathrm{L}^{\mathrm{d}}$ & & \\
\hline Nitrobenzene & & & $0.10 \mathrm{mg} / \mathrm{L}^{\mathrm{d}}$ & $2 \mathrm{mg} / \mathrm{L}^{\mathrm{d}}$ & & \\
\hline $\begin{array}{l}\text { Pentachloro- } \\
\text { phenol }\end{array}$ & & & $0.50 \mathrm{mg} / \mathrm{L}^{\mathrm{d}}$ & $100 \mathrm{mg} / \mathrm{L}^{\mathrm{d}}$ & & \\
\hline Pyridine & & & $0.10 \mathrm{mg} / \mathrm{L}^{\mathrm{d}}$ & $5 \mathrm{mg} / \mathrm{L}^{d}$ & & \\
\hline $\begin{array}{l}\text { 2,4,5-Trichloro- } \\
\text { phenol }\end{array}$ & & & $0.10 \mathrm{mg} / \mathrm{L}^{\mathrm{d}}$ & $400 \mathrm{mg} / \mathrm{L}^{\mathrm{d}}$ & & \\
\hline $\begin{array}{l}\text { 2,4,6-Trichloro- } \\
\text { phenol }\end{array}$ & & & $0.10 \mathrm{mg} / \mathrm{L}^{\mathrm{d}}$ & $2 \mathrm{mg} / \mathrm{L}^{\mathrm{d}}$ & & \\
\hline \multirow{2}{*}{$\begin{array}{c}\text { Total } \\
\text { Pesticides }\end{array}$} & Water & \multirow{2}{*}{$8081 A^{c}$} & \multirow{2}{*}{$\begin{array}{l}\text { Analyte-specific } \\
(\mathrm{CRQL})^{\mathrm{e}}\end{array}$} & \multirow{2}{*}{ NA } & $27^{e}$ & $38-131^{e}$ \\
\hline & Soil & & & & $50^{e}$ & $23-139^{e}$ \\
\hline \multicolumn{7}{|l|}{$\begin{array}{c}\text { TCLP } \\
\text { Pesticides } \\
\end{array}$} \\
\hline Chlordane & \multirow{7}{*}{ Aqueous } & \multirow{7}{*}{$1311 / 8081 A^{c}$} & $0.0005 \mathrm{mg} / \mathrm{L}^{\mathrm{e}}$ & $0.03 \mathrm{mg} / \mathrm{L}^{\mathrm{d}}$ & \multirow{7}{*}{$27^{e}$} & \multirow{7}{*}{$38-131^{e}$} \\
\hline Endrin & & & $0.001 \mathrm{mg} / \mathrm{L}^{\mathrm{e}}$ & $0.02 \mathrm{mg} / \mathrm{L}^{\mathrm{d}}$ & & \\
\hline Heptachlor & & & $0.0005 \mathrm{mg} / \mathrm{L}^{\mathrm{e}}$ & $0.008 \mathrm{mg} / \mathrm{L}^{\mathrm{d}}$ & & \\
\hline $\begin{array}{l}\text { Heptachlor } \\
\text { Epoxide }\end{array}$ & & & $0.0005 \mathrm{mg} / \mathrm{L}^{\mathrm{e}}$ & $0.008 \mathrm{mg} / \mathrm{L}^{\mathrm{d}}$ & & \\
\hline $\begin{array}{c}\text { gamma-BHC } \\
\text { (Lindane) }\end{array}$ & & & $0.0005 \mathrm{mg} / \mathrm{L}^{\mathrm{e}}$ & $0.4 \mathrm{mg} / \mathrm{L}^{\mathrm{d}}$ & & \\
\hline Methoxychlor & & & $0.005 \mathrm{mg} / \mathrm{L}^{\mathrm{e}}$ & $10 \mathrm{mg} / \mathrm{L}^{\mathrm{d}}$ & & \\
\hline Toxaphene & & & $0.05 \mathrm{mg} / \mathrm{L}^{\mathrm{e}}$ & $0.5 \mathrm{mg} / \mathrm{L}^{d}$ & & \\
\hline \multirow[b]{2}{*}{$\begin{array}{l}\text { Polychlorinated } \\
\text { Biphenyls (PCBs) }\end{array}$} & Water & \multirow[b]{2}{*}{$8082^{c}$} & \multirow{2}{*}{$\begin{array}{c}\text { Analyte-specific } \\
\text { contract required } \\
\text { quantitation limits } \\
(\mathrm{CRQL})^{\mathrm{e}}\end{array}$} & \multirow[b]{2}{*}{ NA } & \multirow[b]{2}{*}{ Lab-specific $^{\dagger}$} & \multirow[b]{2}{*}{ Lab-specific ${ }^{\dagger}$} \\
\hline & Soil & & & & & \\
\hline \multirow{2}{*}{$\begin{array}{c}\text { Total } \\
\text { Herbicides }\end{array}$} & Water & \multirow{2}{*}{$8151 A^{c}$} & $1.3 \mu \mathrm{g} / \mathrm{L}^{\mathrm{c}}$ & \multirow{2}{*}{ NA } & \multirow{2}{*}{ Lab-specific $^{\dagger}$} & \multirow{2}{*}{ Lab-specific $^{\dagger}$} \\
\hline & Soil & & $66 \mu \mathrm{g} / \mathrm{kg}^{\mathrm{c}}$ & & & \\
\hline \multicolumn{7}{|l|}{$\begin{array}{c}\text { TCLP } \\
\text { Herbicides }\end{array}$} \\
\hline $2,4-D$ & \multirow{2}{*}{ Aqueous } & \multirow{2}{*}{$1311 / 8151 A^{c}$} & $0.002 \mathrm{mg} / \mathrm{L}^{\mathrm{d}}$ & $10 \mathrm{mg} / \mathrm{L}^{\mathrm{d}}$ & \multirow{2}{*}{ Lab-specific $^{\dagger}$} & \multirow{2}{*}{ Lab-specific $^{\dagger}$} \\
\hline $2,4,5-\mathrm{TP}$ & & & $0.00075 \mathrm{mg} / \mathrm{L}^{\mathrm{d}}$ & $1 \mathrm{mg} / \mathrm{L}^{\mathrm{d}}$ & & \\
\hline
\end{tabular}




\section{Laboratory Chemical, Toxicity Characteristic Leaching Procedure, and Radiochemistry Analytical Requirements for New Mexico Sites}

(Page 3 of 7 )

\begin{tabular}{|c|c|c|c|c|c|c|}
\hline $\begin{array}{l}\text { Parameter or } \\
\text { Analyte }\end{array}$ & $\begin{array}{l}\text { Medium or } \\
\text { Matrix }\end{array}$ & $\begin{array}{l}\text { Analytical } \\
\text { Method }\end{array}$ & $\begin{array}{c}\text { Minimum } \\
\text { Reporting Limit }\end{array}$ & $\begin{array}{l}\text { Regulatory } \\
\text { Limit }\end{array}$ & $\begin{array}{c}\text { Relative } \\
\text { Percent } \\
\text { Difference } \\
\text { (RPD) }^{\mathrm{a}}\end{array}$ & $\begin{array}{c}\text { Percent } \\
\text { Recovery }(\% R)^{b}\end{array}$ \\
\hline \multirow{4}{*}{$\begin{array}{c}\text { Total Petroleum } \\
\text { Hydrocarbons (TPH) }\end{array}$} & $\begin{array}{c}\text { Water } \\
\text { Gasoline }\end{array}$ & \multirow{4}{*}{ 8015B modified ${ }^{c}$} & $0.1 \mathrm{mg} / \mathrm{L}^{\mathrm{g}}$ & \multirow{4}{*}{ NA } & \multirow{4}{*}{ Lab-specific $^{f}$} & \multirow{4}{*}{ Lab-specific $^{\dagger}$} \\
\hline & Soil Gasoline & & $0.5 \mathrm{mg} / \mathrm{kg}^{\mathrm{g}}$ & & & \\
\hline & Water Diesel & & $0.5 \mathrm{mg} / \mathrm{L}^{\mathrm{g}}$ & & & \\
\hline & Soil Diesel & & $25 \mathrm{mg} / \mathrm{kg}^{\mathrm{g}}$ & & & \\
\hline \multirow{2}{*}{ Explosives } & Water & \multirow{2}{*}{$8330^{c}$} & $14 \mu \mathrm{g} / \mathrm{L}^{\mathrm{c}}$ & \multirow{2}{*}{ NA } & \multirow{2}{*}{ Lab-specific $^{\dagger}$} & \multirow{2}{*}{ Lab-specific $^{\dagger}$} \\
\hline & Soil & & $2.2 \mathrm{mg} / \mathrm{kg}^{\mathrm{c}}$ & & & \\
\hline \multirow{2}{*}{$\begin{array}{c}\text { Polychlorinated } \\
\text { Dioxins and Furans }\end{array}$} & Water & \multirow{2}{*}{$8280 \mathrm{~A} / 8290^{\circ}$} & $0.05 \mu \mathrm{g} / \mathrm{L}^{\mathrm{c}}$ & \multirow{2}{*}{ NA } & \multirow{2}{*}{ Lab-specific $^{\dagger}$} & \multirow{2}{*}{ Lab-specific $^{f}$} \\
\hline & Soil & & $5 \mu \mathrm{g} / \mathrm{kg}^{\mathrm{c}}$ & & & \\
\hline \multicolumn{7}{|c|}{ INORGANICS } \\
\hline \multicolumn{7}{|l|}{$\begin{array}{c}\text { Target Analyte List } \\
\text { Metals }\end{array}$} \\
\hline \multirow{2}{*}{ Aluminum } & Water & $6010 \mathrm{~B}^{\mathrm{c}}$ & $100 \mu \mathrm{g} / \mathrm{L}^{\mathrm{g}, \mathrm{h}}$ & \multirow{22}{*}{ NA } & \multirow{22}{*}{$20^{\mathrm{h}}$} & \multirow{22}{*}{$75-125^{\mathrm{h}}$} \\
\hline & Soil & $6010 \mathrm{~B}^{\mathrm{c}}$ & $10 \mathrm{mg} / \mathrm{kg}^{\mathrm{g}, \mathrm{h}}$ & & & \\
\hline \multirow{2}{*}{ Antimony } & Water & $6010 \mathrm{~B}^{\mathrm{c}}$ & $20 \mu \mathrm{g} / \mathrm{L}^{\mathrm{g}, \mathrm{h}}$ & & & \\
\hline & Soil & $6010 \mathrm{~B}^{\mathrm{c}}$ & $2 \mathrm{mg} / \mathrm{kg}^{\mathrm{g}, \mathrm{h}}$ & & & \\
\hline \multirow{2}{*}{ Arsenic } & Water & $6010 \mathrm{~B}^{\mathrm{c}}$ & $10 \mu \mathrm{g} / \mathrm{L}^{\mathrm{g}, \mathrm{h}}$ & & & \\
\hline & Soil & $6010 \mathrm{~B}^{\mathrm{c}}$ & $1 \mathrm{mg} / \mathrm{kg}^{\mathrm{g}, \mathrm{h}}$ & & & \\
\hline \multirow{2}{*}{ Barium } & Water & $6010 B^{c}$ & $200 \mu \mathrm{g} / \mathrm{L}^{\mathrm{g}, \mathrm{h}}$ & & & \\
\hline & Soil & $6010 \mathrm{~B}^{\mathrm{c}}$ & $20 \mathrm{mg} / \mathrm{kg}^{\mathrm{g}, \mathrm{h}}$ & & & \\
\hline \multirow{2}{*}{ Beryllium } & Water & $6010 \mathrm{~B}^{\mathrm{c}}$ & $5 \mu \mathrm{g} / \mathrm{L}^{\mathrm{g}, \mathrm{h}}$ & & & \\
\hline & Soil & $6010 \mathrm{~B}^{\mathrm{c}}$ & $0.5 \mathrm{mg} / \mathrm{kg}^{\mathrm{g}, \mathrm{h}}$ & & & \\
\hline \multirow{2}{*}{ Boron } & Water & $6010 \mathrm{~B}^{\mathrm{c}}$ & $100 \mu \mathrm{g} / \mathrm{L}^{\mathrm{g}, \mathrm{h}}$ & & & \\
\hline & Soil & $6010 \mathrm{~B}^{\mathrm{c}}$ & $10 \mathrm{mg} / \mathrm{kg}^{\mathrm{g}, \mathrm{h}}$ & & & \\
\hline \multirow{2}{*}{ Cadmium } & Water & $6010 \mathrm{~B}^{\mathrm{c}}$ & $5 \mu \mathrm{g} / \mathrm{L}^{\mathrm{g}, \mathrm{h}}$ & & & \\
\hline & Soil & $6010 \mathrm{~B}^{\mathrm{c}}$ & $0.5 \mathrm{mg} / \mathrm{kg}^{\mathrm{g}, \mathrm{h}}$ & & & \\
\hline \multirow{2}{*}{ Calcium } & Water & $6010 \mathrm{~B}^{\mathrm{c}}$ & $1,000 \mu \mathrm{g} / \mathrm{L}^{\mathrm{g}, \mathrm{h}}$ & & & \\
\hline & Soil & $6010 \mathrm{~B}^{\mathrm{c}}$ & $100 \mathrm{mg} / \mathrm{kg}^{\mathrm{g}, \mathrm{h}}$ & & & \\
\hline \multirow{2}{*}{ Chromium } & Water & $6010 \mathrm{~B}^{\mathrm{c}}$ & $10 \mu \mathrm{g} / \mathrm{L}^{\mathrm{g}, \mathrm{h}}$ & & & \\
\hline & Soil & $6010 \mathrm{~B}^{\mathrm{c}}$ & $1 \mathrm{mg} / \mathrm{kg}^{\mathrm{g}, \mathrm{h}}$ & & & \\
\hline Cobolt & Water & $6010 B^{c}$ & $10 \mu \mathrm{g} / \mathrm{L}^{\mathrm{g}, \mathrm{h}}$ & & & \\
\hline Survait & Soil & $6010 \mathrm{~B}^{\mathrm{c}}$ & $1 \mathrm{mg} / \mathrm{kg}^{\mathrm{g}, \mathrm{h}}$ & & & \\
\hline Conner & Water & $6010 \mathrm{~B}^{\mathrm{c}}$ & $10 \mu \mathrm{g} / \mathrm{L}^{\mathrm{g}, \mathrm{h}}$ & & & \\
\hline וים & Soil & $6010 \mathrm{~B}^{\mathrm{c}}$ & $1 \mathrm{mg} / \mathrm{kg}^{\mathrm{g}, \mathrm{h}}$ & & & \\
\hline
\end{tabular}




\section{Laboratory Chemical, Toxicity Characteristic Leaching Procedure, and Radiochemistry Analytical Requirements for New Mexico Sites}

(Page 4 of 7 )

\begin{tabular}{|c|c|c|c|c|c|c|}
\hline $\begin{array}{l}\text { Parameter or } \\
\text { Analyte }\end{array}$ & $\begin{array}{l}\text { Medium or } \\
\text { Matrix }\end{array}$ & $\begin{array}{l}\text { Analytical } \\
\text { Method }\end{array}$ & $\begin{array}{c}\text { Minimum } \\
\text { Reporting Limit }\end{array}$ & $\begin{array}{l}\text { Regulatory } \\
\text { Limit }\end{array}$ & $\begin{array}{c}\text { Relative } \\
\text { Percent } \\
\text { Difference } \\
\text { (RPD) }^{\mathrm{a}} \\
\end{array}$ & $\begin{array}{c}\text { Percent } \\
\text { Recovery }(\% R)^{b}\end{array}$ \\
\hline \multirow{2}{*}{ Iron } & Water & $6010 B^{c}$ & $100 \mu \mathrm{g} / \mathrm{L}^{\mathrm{g}, \mathrm{h}}$ & \multirow{34}{*}{ NA } & \multirow{34}{*}{$20^{\mathrm{h}}$} & \multirow{34}{*}{$75-125^{\mathrm{h}}$} \\
\hline & Soil & $6010 \mathrm{~B}^{\mathrm{c}}$ & $10 \mathrm{mg} / \mathrm{kg}^{\mathrm{g}, \mathrm{h}}$ & & & \\
\hline \multirow{2}{*}{ Lead } & Water & $6010 \mathrm{~B}^{\mathrm{c}}$ & $3 \mu \mathrm{g} / \mathrm{L}^{\mathrm{g}, \mathrm{h}}$ & & & \\
\hline & Soil & $6010 \mathrm{~B}^{\mathrm{c}}$ & $0.3 \mathrm{mg} / \mathrm{kg}^{\mathrm{g}, \mathrm{h}}$ & & & \\
\hline \multirow{2}{*}{ Lithium } & Water & $6010 B^{c}$ & $10 \mu \mathrm{g} / \mathrm{L}^{\mathrm{g}, \mathrm{h}}$ & & & \\
\hline & Soil & $6010 \mathrm{~B}^{\mathrm{c}}$ & $1 \mathrm{mg} / \mathrm{kg}^{\mathrm{g}, \mathrm{h}}$ & & & \\
\hline \multirow{2}{*}{ Magnesium } & Water & $6010 B^{c}$ & $1,000 \mu \mathrm{g} / \mathrm{L}^{\mathrm{g}, \mathrm{h}}$ & & & \\
\hline & Soil & $6010 B^{c}$ & $100 \mathrm{mg} / \mathrm{kg}^{\mathrm{g}, \mathrm{h}}$ & & & \\
\hline \multirow{2}{*}{ Manganese } & Water & $6010 \mathrm{~B}^{\mathrm{c}}$ & $10 \mu \mathrm{g} / \mathrm{L}^{\mathrm{g}, \mathrm{h}}$ & & & \\
\hline & Soil & $6010 B^{c}$ & $1 \mathrm{mg} / \mathrm{kg}^{\mathrm{g}, \mathrm{h}}$ & & & \\
\hline \multirow{2}{*}{ Mercury } & Water & $7470 A^{c}$ & $0.2 \mu \mathrm{g} / \mathrm{L}^{\mathrm{g}, \mathrm{h}}$ & & & \\
\hline & Soil & $7471 A^{c}$ & $0.1 \mathrm{mg} / \mathrm{kg}^{\mathrm{g}, \mathrm{h}}$ & & & \\
\hline \multirow{2}{*}{ Molybdenum } & Water & $6010 B^{c}$ & $10 \mu \mathrm{g} / \mathrm{L}^{\mathrm{g}, \mathrm{h}}$ & & & \\
\hline & Soil & $6010 \mathrm{~B}^{\mathrm{c}}$ & $1 \mathrm{mg} / \mathrm{kg}^{\mathrm{g}, \mathrm{h}}$ & & & \\
\hline \multirow{2}{*}{ Nickel } & Water & $6010 B^{c}$ & $20 \mu \mathrm{g} / \mathrm{L}^{\mathrm{g}, \mathrm{h}}$ & & & \\
\hline & Soil & $6010 \mathrm{~B}^{\mathrm{c}}$ & $2 \mathrm{mg} / \mathrm{kg}^{\mathrm{g}, \mathrm{h}}$ & & & \\
\hline \multirow{2}{*}{ Phosphorus } & Water & $6010 \mathrm{~B}^{\mathrm{c}}$ & $200 \mu \mathrm{g} / \mathrm{L}^{\mathrm{g}, \mathrm{h}}$ & & & \\
\hline & Soil & $6010 \mathrm{~B}^{\mathrm{c}}$ & 20 mg/kg ${ }^{g, h}$ & & & \\
\hline \multirow{2}{*}{ Potassium } & Water & $6010 \mathrm{~B}^{\mathrm{c}}$ & $1,000 \mu \mathrm{g} / \mathrm{L}^{\mathrm{g}, \mathrm{h}}$ & & & \\
\hline & Soil & $6010 \mathrm{~B}^{\mathrm{c}}$ & $100 \mathrm{mg} / \mathrm{kg}^{\mathrm{g}, \mathrm{h}}$ & & & \\
\hline \multirow{2}{*}{ Selenium } & Water & $6010 B^{c}$ & $5 \mu \mathrm{g} / \mathrm{L}^{\mathrm{g}, \mathrm{h}}$ & & & \\
\hline & Soil & $6010 B^{c}$ & $0.5 \mathrm{mg} / \mathrm{kg}^{\mathrm{g}, \mathrm{h}}$ & & & \\
\hline \multirow{2}{*}{ Silica } & Water & $6010 \mathrm{~B}^{\mathrm{c}}$ & $50 \mu \mathrm{g} / \mathrm{L}^{\mathrm{g}, \mathrm{h}}$ & & & \\
\hline & Soil & $6010 B^{c}$ & $5 \mathrm{mg} / \mathrm{kg}^{\mathrm{g}, \mathrm{h}}$ & & & \\
\hline \multirow{2}{*}{ Silver } & Water & $6010 B^{c}$ & $10 \mu \mathrm{g} / \mathrm{L}^{\mathrm{g}, \mathrm{h}}$ & & & \\
\hline & Soil & $6010 B^{c}$ & $1 \mathrm{mg} / \mathrm{kg}^{\mathrm{g}, \mathrm{h}}$ & & & \\
\hline \multirow{2}{*}{ Sodium } & Water & $6010 B^{c}$ & $1,000 \mu \mathrm{g} / \mathrm{L}^{\mathrm{g}, \mathrm{h}}$ & & & \\
\hline & Soil & $6010 B^{c}$ & $100 \mathrm{mg} / \mathrm{kg}^{\mathrm{g}, \mathrm{h}}$ & & & \\
\hline \multirow{2}{*}{ Strontium } & Water & $6010 \mathrm{~B}^{\mathrm{c}}$ & $50 \mu \mathrm{g} / \mathrm{L}^{\mathrm{g}, \mathrm{h}}$ & & & \\
\hline & Soil & $6010 B^{c}$ & $1 \mathrm{mg} / \mathrm{kg}^{\mathrm{g}, \mathrm{h}}$ & & & \\
\hline \multirow{2}{*}{ Thallium } & Water & $6010 \mathrm{~B}^{\mathrm{c}}$ & $5 \mu \mathrm{g} / \mathrm{L}^{\mathrm{g}, \mathrm{h}}$ & & & \\
\hline & Soil & $6010 \mathrm{~B}^{\mathrm{c}}$ & $0.5 \mathrm{mg} / \mathrm{kg}^{\mathrm{g}, \mathrm{h}}$ & & & \\
\hline \multirow{2}{*}{ Tin } & Water & $6010 \mathrm{~B}^{\mathrm{c}}$ & $10 \mu \mathrm{g} / \mathrm{L}^{\mathrm{g}, \mathrm{h}}$ & & & \\
\hline & Soil & $6010 \mathrm{~B}^{\mathrm{c}}$ & $2 \mathrm{mg} / \mathrm{kg}^{\mathrm{g}, \mathrm{h}}$ & & & \\
\hline
\end{tabular}




\section{Laboratory Chemical, Toxicity Characteristic Leaching Procedure, and Radiochemistry Analytical Requirements for New Mexico Sites}

(Page 5 of 7 )

\begin{tabular}{|c|c|c|c|c|c|c|}
\hline $\begin{array}{l}\text { Parameter or } \\
\text { Analyte }\end{array}$ & $\begin{array}{l}\text { Medium or } \\
\text { Matrix }\end{array}$ & $\begin{array}{l}\text { Analytical } \\
\text { Method }\end{array}$ & $\begin{array}{l}\text { Minimum } \\
\text { Reporting Limit }\end{array}$ & $\begin{array}{l}\text { Regulatory } \\
\text { Limit }\end{array}$ & $\begin{array}{c}\text { Relative } \\
\text { Percent } \\
\text { Difference } \\
\text { (RPD) }^{\mathrm{a}}\end{array}$ & $\begin{array}{c}\text { Percent } \\
\text { Recovery }(\% R)^{\mathrm{b}}\end{array}$ \\
\hline \multirow{2}{*}{ Titanium } & Water & $6010 B^{c}$ & $20 \mu \mathrm{g} / \mathrm{L}^{\mathrm{g}, \mathrm{h}}$ & \multirow{8}{*}{ NA } & \multirow{8}{*}{$20^{h}$} & \multirow{8}{*}{$75-125^{h}$} \\
\hline & Soil & $6010 B^{c}$ & $1 \mathrm{mg} / \mathrm{kg}^{\mathrm{g}, \mathrm{h}}$ & & & \\
\hline \multirow{2}{*}{ Uranium } & Water & $6010 B^{c}$ & $20 \mu \mathrm{g} / \mathrm{L}^{\mathrm{g}, \mathrm{h}}$ & & & \\
\hline & Soil & $6010 B^{c}$ & $20 \mathrm{mg} / \mathrm{kg}^{\mathrm{g}, \mathrm{h}}$ & & & \\
\hline \multirow{2}{*}{ Vanadium } & Water & $6010 B^{c}$ & $10 \mu \mathrm{g} / \mathrm{L}^{\mathrm{g}, \mathrm{h}}$ & & & \\
\hline & Soil & $6010 B^{c}$ & $1 \mathrm{mg} / \mathrm{kg}^{\mathrm{g}, \mathrm{h}}$ & & & \\
\hline \multirow{2}{*}{ Zinc } & Water & $6010 \mathrm{~B}^{\mathrm{c}}$ & $20 \mu \mathrm{g} / \mathrm{L}^{\mathrm{g}, \mathrm{h}}$ & & & \\
\hline & Soil & $6010 \mathrm{~B}^{\mathrm{c}}$ & $2 \mathrm{mg} / \mathrm{kg}^{\mathrm{g}, \mathrm{h}}$ & & & \\
\hline \multicolumn{7}{|l|}{$\begin{array}{c}\text { TCLP RCRA } \\
\text { Metals }\end{array}$} \\
\hline Arsenic & \multirow{8}{*}{ Aqueous } & \multirow{8}{*}{$\begin{array}{l}1311 / 6010 B^{c} \\
1311 / 7470 A^{c}\end{array}$} & $0.10 \mathrm{mg} / \mathrm{L}^{\mathrm{g}, \mathrm{h}}$ & $5 \mathrm{mg} / \mathrm{L}^{\mathrm{d}}$ & \multirow{10}{*}{$20^{h}$} & \multirow{10}{*}{$75-125^{\mathrm{h}}$} \\
\hline Barium & & & $2 \mathrm{mg} / \mathrm{L}^{\mathrm{g}, \mathrm{h}}$ & $100 \mathrm{mg} / \mathrm{L}^{\mathrm{d}}$ & & \\
\hline Cadmium & & & $0.05 \mathrm{mg} / \mathrm{L}^{\mathrm{g}, \mathrm{h}}$ & $1 \mathrm{mg} / \mathrm{L}^{\mathrm{d}}$ & & \\
\hline Chromium & & & $0.10 \mathrm{mg} / \mathrm{L}^{\mathrm{g}, \mathrm{h}}$ & $5 \mathrm{mg} / \mathrm{L}^{\mathrm{d}}$ & & \\
\hline Lead & & & $0.03 \mathrm{mg} / \mathrm{L}^{\mathrm{g}, \mathrm{h}}$ & $5 \mathrm{mg} / \mathrm{L}^{\mathrm{d}}$ & & \\
\hline Mercury & & & $0.002 \mathrm{mg} / \mathrm{L}^{\mathrm{g}, \mathrm{h}}$ & $0.2 \mathrm{mg} / \mathrm{L}^{\mathrm{d}}$ & & \\
\hline Selenium & & & $0.05 \mathrm{mg} / \mathrm{L}^{\mathrm{g}, \mathrm{h}}$ & $1 \mathrm{mg} / \mathrm{L}^{\mathrm{d}}$ & & \\
\hline Silver & & & $0.10 \mathrm{mg} / \mathrm{L}^{\mathrm{g}, \mathrm{h}}$ & $5 \mathrm{mg} / \mathrm{L}^{\mathrm{d}}$ & & \\
\hline \multirow{2}{*}{ Cyanide } & Water & \multirow{2}{*}{$9010 \mathrm{~B}^{\mathrm{c}}$} & $0.01 \mathrm{mg} / \mathrm{L}^{\mathrm{h}}$ & \multirow{2}{*}{ NA } & & \\
\hline & Soil & & $1.0 \mathrm{mg} / \mathrm{kg}^{\mathrm{h}}$ & & & \\
\hline \multirow[b]{2}{*}{ Sulfide } & Water & & $0.4 \mathrm{mg} / \mathrm{L}^{\mathrm{c}}$ & & \multirow{4}{*}{ Lab-specific $^{f}$} & \multirow{4}{*}{ Lab-specific ${ }^{f}$} \\
\hline & $\begin{array}{c}\text { Soil or } \\
\text { Sediment }\end{array}$ & $9030 \mathrm{~B} / 9034^{\mathrm{C}}$ & $10 \mathrm{mg} / \mathrm{kg}^{\mathrm{g}}$ & NA & & \\
\hline \multirow{2}{*}{$\mathrm{pH} /$ Corrosivity } & Water & $9040 \mathrm{~B}^{\mathrm{c}}$ & \multirow{2}{*}{ NA } & $\mathrm{pH}>2^{\mathrm{i}}$ & & \\
\hline & Soil & $9045 C^{c}$ & & $\mathrm{pH}<12.5^{\mathrm{i}}$ & & \\
\hline \multirow[b]{2}{*}{ Ignitability } & Water & $1010^{c}$ & \multirow[b]{2}{*}{ NA } & $\begin{array}{l}\text { Flash Point } \\
<140^{\circ} F^{d}\end{array}$ & \multirow[b]{2}{*}{ NA } & \multirow[b]{2}{*}{ NA } \\
\hline & Soil & $1030^{c}$ & & $\begin{array}{c}\text { Burn Rate } \\
>2.2 \mathrm{~mm} / \mathrm{sec} \\
\text { nonmetals; } \\
>0.17 \mathrm{~mm} / \mathrm{sec} \\
\text { metals }\end{array}$ & & \\
\hline \multirow{2}{*}{$\begin{array}{l}\text { Total Dissolved } \\
\text { Solids }\end{array}$} & Water & 16019 & ah-snecific & \multirow{4}{*}{ NA } & \multirow{2}{*}{ Lab-specific } & \multirow{2}{*}{$80-120$} \\
\hline & Soil & 100.1 & Lav-specticic & & & \\
\hline \multirow{2}{*}{ Bromide } & Water & EPA 300.0 & $100 \mu \mathrm{g} / \mathrm{L}^{\mathrm{g}}$ & & \multirow{2}{*}{15} & \multirow{2}{*}{$85-115$} \\
\hline & Soil & EPA 300.0 & $2 \mathrm{mg} / \mathrm{kg}^{\mathrm{g}}$ & & & \\
\hline
\end{tabular}




\section{Laboratory Chemical, Toxicity Characteristic Leaching Procedure, and Radiochemistry Analytical Requirements for New Mexico Sites}

(Page 6 of 7 )

\begin{tabular}{|c|c|c|c|c|c|c|}
\hline $\begin{array}{c}\text { Parameter or } \\
\text { Analyte }\end{array}$ & $\begin{array}{l}\text { Medium or } \\
\text { Matrix }\end{array}$ & $\begin{array}{l}\text { Analytical } \\
\text { Method }\end{array}$ & $\begin{array}{c}\text { Minimum } \\
\text { Reporting Limit }\end{array}$ & $\begin{array}{l}\text { Regulatory } \\
\text { Limit }\end{array}$ & $\begin{array}{c}\text { Relative } \\
\text { Percent } \\
\text { Difference } \\
\text { (RPD) }^{\mathrm{a}} \\
\end{array}$ & $\begin{array}{c}\text { Percent } \\
\text { Recovery }(\% \mathbf{R})^{\mathrm{b}}\end{array}$ \\
\hline \multirow{2}{*}{ Chloride } & Water & EPA 300.0 & $200 \mu \mathrm{g} / \mathrm{L}^{\mathrm{g}}$ & \multirow{8}{*}{ NA } & \multirow{4}{*}{20} & \multirow{2}{*}{$75-115$} \\
\hline & Soil & EPA 300.0 & $2 \mathrm{mg} / \mathrm{kg}^{\mathrm{g}}$ & & & \\
\hline \multirow{2}{*}{ Fluoride } & Water & EPA 300.0 & $200 \mu \mathrm{g} / \mathrm{L}^{\mathrm{g}}$ & & & \multirow{2}{*}{$80-120$} \\
\hline & Soil & EPA 300.0 & $2 \mathrm{mg} / \mathrm{kg}^{\mathrm{g}}$ & & & \\
\hline \multirow{2}{*}{ Nitrate as $\mathrm{NO}_{3}$} & Water & EPA 300.0 & $200 \mu \mathrm{g} / \mathrm{L}^{\mathrm{g}}$ & & \multirow{4}{*}{15} & \multirow{4}{*}{$85-115$} \\
\hline & Soil & EPA 300.0 & $2 \mathrm{mg} / \mathrm{kg}^{\mathrm{g}}$ & & & \\
\hline \multirow{2}{*}{ Sulfate } & Water & EPA 300.0 & $1,000 \mu \mathrm{g} / \mathrm{L}^{\mathrm{g}}$ & & & \\
\hline & Soil & EPA 300.0 & $2 \mathrm{mg} / \mathrm{kg}^{\mathrm{g}}$ & & & \\
\hline \multicolumn{7}{|c|}{ RADIOCHEMISTRY } \\
\hline \multirow{2}{*}{$\begin{array}{l}\text { Gamma-emitting } \\
\text { Radionuclides }^{j}\end{array}$} & Water & EPA $901.1^{\mathrm{k}}$ & \multirow{2}{*}{ Isotope-specific ${ }^{m}$} & \multirow{2}{*}{ NA } & 20 & \multirow{10}{*}{$\begin{array}{c}\text { Tracer Yield } \\
30-105 \\
\text { Laboratory } \\
\text { Control Sample } \\
\text { Yield } \\
80-120\end{array}$} \\
\hline & Soil/Biota & HASL $300^{\prime}$ & & & 35 & \\
\hline \multirow{2}{*}{$\begin{array}{l}\text { Isotopic } \\
\text { Plutonium }\end{array}$} & Water & $\begin{array}{c}\text { HASL } 300^{\prime} \text { or } \\
\text { ASTM D3865-97 }^{\text {n }}\end{array}$ & $0.1 \mathrm{pCi} / \mathrm{L}$ & \multirow{2}{*}{ NA } & 20 & \\
\hline & Soil/Biota & $\begin{array}{c}\text { HASL } 300^{\prime} \text { or } \\
\text { ASTM C1001-90 }\end{array}$ & $0.05 \mathrm{pCi} / \mathrm{g}$ & & 35 & \\
\hline \multirow{2}{*}{$\begin{array}{l}\text { Isotopic } \\
\text { Uranium }\end{array}$} & Water & HASL $300^{\prime}$ & $0.1 \mathrm{pCi} / \mathrm{L}$ & \multirow{2}{*}{ NA } & 20 & \\
\hline & Soil/Biota & HASL $300^{1}$ & $0.05 \mathrm{pCi} / \mathrm{g}$ & & 35 & \\
\hline \multirow{2}{*}{ Strontium - $90^{\mathrm{j}}$} & Water & & $1 \mathrm{pCi} / \mathrm{L}$ & \multirow{2}{*}{ NA } & 20 & \\
\hline & Soil/Biota & ASTM D5811-95 & $0.5 \mathrm{pCi} / \mathrm{g}$ & & 35 & \\
\hline \multirow{2}{*}{ Americium-241 } & Water & ASTM D3972 & $0.1 \mathrm{pCi} / \mathrm{L}$ & \multirow{2}{*}{ NA } & 20 & \\
\hline & Soil/Biota & ASTM 90M & $0.05 \mathrm{pCi} / \mathrm{g}$ & & 35 & \\
\hline \multirow{2}{*}{ Gross Alpha } & Water & EPA $900.0^{k}$ & $4 \mathrm{pCi} / \mathrm{L}$ & \multirow{2}{*}{ NA } & 20 & \multirow{6}{*}{$\begin{array}{c}\text { Laboratory } \\
\text { Control Sample } \\
\text { Yield } \\
80-120\end{array}$} \\
\hline & Soil & Lab Specific $^{\circ}$ & $4 \mathrm{pCi} / \mathrm{g}$ & & 35 & \\
\hline \multirow{2}{*}{ Gross Beta } & Water & EPA $900.0^{k}$ & $4 \mathrm{pCi} / \mathrm{L}$ & \multirow{2}{*}{ NA } & 20 & \\
\hline & Soil & Lab Specific $^{\circ}$ & $4 \mathrm{pCi} / \mathrm{g}$ & & 35 & \\
\hline \multirow{2}{*}{ Tritium $^{\mathrm{j}}$} & Water & EPA $900.0^{k}$ & $400 \mathrm{pCi} / \mathrm{L}$ & NA & 35 & \\
\hline & Soil & EERFH $01^{p}$ & $5 \mathrm{pCi} / \mathrm{g}$ & TIV & 20 & \\
\hline Rodium 206/200 & Water & PAI SOP $712 / 746$ & $1 \mathrm{pCi} / \mathrm{L}$ & $3 \mathrm{pCi} / \mathrm{L}$ & 20 & $75-125$ \\
\hline Radium- $\angle 20 / 2<8$ & Soil & PAI SOP 739 & $0.5 \mathrm{pCi} / \mathrm{g}$ & $5 \mathrm{pCi} / \mathrm{g}$ & 30 & $85-115$ \\
\hline Carbon-14 & Water & Lab Specific ${ }^{\circ}$ & $\begin{array}{l}1 \text { Percent Modern } \\
\text { Carbon }\end{array}$ & NA & $\begin{array}{c}\text { +/- } 1 \text { Percent } \\
\text { Modern Carbon }\end{array}$ & $\begin{array}{l}\text { Within } 1 \text { Percent } \\
\text { Modern Carbon }^{\text {s }}\end{array}$ \\
\hline & & & TABLE ISOTOPES & & & \\
\hline Carbon-13 & & & & & o 2 nor mir & Within 0.4 per mil \\
\hline Oxygen-18 & Water & Lah Snecifico & $N A^{t}-a^{-}$ & $N A$ & $+t=0 .<$ pet IIIII & of Standard ${ }^{\mathrm{s}}$ \\
\hline Deuterium & & & & & $+/-1$ per mil ${ }^{r}$ & $\begin{array}{l}\text { Within } 2 \text { per mil } \\
\text { of Standard }\end{array}$ \\
\hline
\end{tabular}




\title{
Laboratory Chemical, Toxicity Characteristic Leaching Procedure, and Radiochemistry Analytical Requirements for New Mexico Sites
} (Page 7 of 7 )

\author{
${ }^{\text {aRPD }}$ is used to Calculate Precision. \\ Precision is estimated from the relative percent difference of the concentrations measured for the matrix spike and matrix spike \\ duplicate analyses of unspiked field samples, or field duplicates of unspiked samples. It is calculated by: \\ $R P D=100 \times\left\{\left(\left|C_{1}-C_{2}\right|\right) /\left[\left(C_{1}+C_{2}\right) / 2\right]\right\}$, where $C_{1}=$ Concentration of the analyte in the first sample aliquot, $C_{2}=$ Concentration of the \\ analyte in the second sample aliquot. \\ bo $R$ is used to Calculate Accuracy. \\ Accuracy is assessed from the recovery of analytes spiked into a blank or sample matrix of interest, or from the recovery of \\ surrogate compounds spiked into each sample. The recovery of each spiked analyte is calculated by: $\% R=100 \times\left(C_{s}-C_{u} / C_{n}\right)$, \\ where $\mathrm{C}_{\mathrm{s}}=$ Concentration of the analyte in the spiked sample, $\mathrm{C}_{\mathrm{u}}=$ Concentration of the analyte in the unspiked sample, \\ $\mathrm{C}_{\mathrm{n}}=$ Concentration increase that should result from spiking the sample \\ 'U.S. Environmental Protection Agency's (EPAs) Test Methods for Evaluating Solid Waste, 3rd Edition, Parts 1-4, SW-846 \\ (EPA, 1996) \\ 'Estimated Quantitation Limit as given in SW-846 (EPA, 1996) \\ eEPA Contract Laboratory Program Statement of Work for Organic Analysis (EPA, 1988b; and 1991) \\ ${ }^{\dagger}$ In-House Generated RPD and \%R Performance Criteria \\ It is necessary for laboratories to develop in-house performance criteria and compare them to those in the methods. The laboratory \\ begins by analyzing 15-20 samples of each matrix and calculating the mean \%R for each analyte. The standard deviation (SD) of \\ each $\% R$ is then calculated, and the warning and control limits for each analyte are established at \pm 2 SD and \pm 3 SD from the \\ mean, respectively. If the warning limit is exceeded during the analysis of any sample delivery group (SDG), the laboratory \\ institutes corrective action to bring the analytical system back into control. If the control limit is exceeded, the sample results for that \\ SDG are considered unacceptable. These limits are reviewed after every 20-30 field samples of the same matrix and are updated \\ at least semiannually. The laboratory tracks trends in both performance and control limits by the use of control charts. The \\ laboratory's compliance with these requirements is confirmed as part of an annual laboratory audit. Similar procedures are followed \\ in order to generate acceptance criteria for precision measurements. \\ ${ }^{9}$ Minimum reporting level as directed to laboratory by contractor. \\ hEPA Contract Laboratory Program Statement of Work for Inorganic Analysis (EPA, 1988a; and 1994a) \\ 'RCRA Regulations and Keyword Index, 1998 Edition \\ IIsotopic minimum detectable concentrations are defined during the DQO process and specified in the CAIP, as applicable. \\ ${ }^{\mathrm{k}}$ Prescribed Procedures for Measurements of Radioactivity in Drinking Water (EPA, 1980) or equivalent method \\ 'Environmental Measurements Laboratory Procedures Manual (DOE, 1997) or equivalent method \\ mIsotope-Specific Minimum Reporting Limit to be specified in the work plan \\ ${ }^{\mathrm{n}}$ American Society for Testing and Materials, or equivalent method. \\ 'Laboratory-Specific Method, as preapproved by Analytical Services \\ PU.S. Environmental Protection Agency, Eastern Environmental Radiation Facility

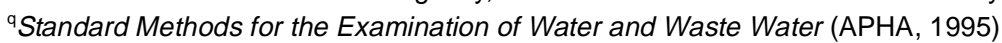 \\ 'Measure of precision as directed to the laboratory by contractor. \\ sMeasure of accuracy as directed to the laboratory by contractor. \\ tA ratio is reported; therefore, a minimum reporting limit is not applicable. \\ Definitions: \\ $\mu \mathrm{g} / \mathrm{kg}=$ Microgram(s) per kilogram \\ $\mathrm{mg} / \mathrm{kg}=$ Milligram(s) per kilogram \\ $\mathrm{pCi} / \mathrm{L}=$ Picocurie(s) per liter \\ $\mathrm{mg} / \mathrm{L}=$ Milligram(s) per liter \\ $\mathrm{pCi} / \mathrm{g}=$ Picocurie(s) per gram \\ $\mu \mathrm{g} / \mathrm{L}=$ Microgram(s) per liter
}




\section{Table References}

APHA, see American Public Health Association.

American Public Health Association. 1995. Standard Methods for the Examination of Water and Waste Water, 19th Edition. Washington, DC.

RCRA Regulations and Keyword Index. 1998. ISSN 1074-1364. New York, NY: Elsevier Science, Inc.

U.S. Department of Energy. 1997. Environmental Measurements Laboratory Procedures Manual, HASL-300, 28th Edition, Vol. 1. New York, NY.

U.S. Environmental Protection Agency. 1980. Prescribed Procedures for Measurements of Radioactivity in Drinking Water, EPA-600/4-80-032. Washington, DC.

U.S. Environmental Protection Agency. 1988a. USEPA Contract Laboratory Program Statement of Work for Inorganic Analysis, SOW No. 788, EPA/540/R-94/093. Washington, DC.

U.S. Environmental Protection Agency. 1988b. USEPA Contract Laboratory Program Statement of Work for Organic Analysis, SOW No. 2/88, EPA/540/R-94/096. Washington, DC.

U.S. Environmental Protection Agency. 1991. USEPA Contract Laboratory Program Statement of Work for Organic Analysis, OLMO 1.8, EPA/540/R-94/078. Washington, DC.

U.S. Environmental Protection Agency. 1994a. USEPA Contract Laboratory Program Statement of Work for Inorganic Analysis, ILMO 3.0, EPA/540/R-94/076. Washington, DC.

U.S. Environmental Protection Agency. 1996. Test Methods for Evaluating Solid Waste, Physical/Chemical Methods, SW-846, $3^{\text {rd }}$ Edition, CD-ROM PB97-501928GEI. Washington, DC. 


\section{Appendix C}

\section{Results of Gasbuggy Preliminary Field Investigation (August - September, 2000)}




\section{C.1.0 Introduction}

This appendix presents the investigation activities and analytical results from the preliminary field investigation conducted at the Gasbuggy Site in Rio Arriba County, New Mexico, during August and September of 2000. The Gasbuggy Site is located approximately 55 air miles east of Farmington, New Mexico, in the Carson National Forest. The site is made up of five operational areas (i.e., Surface Ground Zero area, the Well GB-D area, the Recording Trailer Park, the Control Point, and the Helicopter Pad) (Figure 2-1). Additional information on the site history is presented in the main body of the Site Characterization Work Plan (see Section 2.0) and will not be presented here.

\section{C.1.1 Preliminary Field Investigation Objectives}

The seven primary objectives for the preliminary field investigation of the surface/shallow subsurface were to:

- Complete necessary biological and cultural resource surveys for operational areas not previously surveyed (all except the SGZ area), so that a Special Use Permit may be obtained from the CNF, Jicarilla Ranger District for future work in these areas.

- Complete surface geophysical investigations for all operational areas where shallow subsurface contamination is suspected to identify suspect AOCs and refine sampling locations.

- Collect soil samples to identify the presence and nature of COPCs at the SGZ area.

- Locate the shallow groundwater table in the SGZ area with planned equipment (direct-push), if possible.

- Collect shallow groundwater samples in the SGZ area, if shallow groundwater is found.

- Verify location of septic tanks in the SGZ.

- Verify septic tanks in SGZ area were closed.

Biological and cultural resource surveys were completed by a contractor approved by the CNF. Surface geophysical investigations were carried out using several electromagnetic (EM) techniques (e.g., EM31 and EM61) and ground-penetrating radar (GPR). Soil samples were collected from within the SGZ area and analyzed as planned. 
The other objectives were not met. Limitations of the direct-push technology and site conditions limited the depth to which subsurface observations could be made. Several boreholes were drilled beyond $20 \mathrm{ft}$ bgs and one to $36 \mathrm{ft}$ bgs without contacting groundwater. No shallow groundwater samples were collected. The septic tanks indicated by historical documentation were not definitively located; therefore, closure was not verified. The investigation strategies for the shallow groundwater and septic tanks are presented in Section 4.0 of the Work Plan.

Additionally, two tasks were planned for the subsurface investigation. These included sampling and video logging of Well EPNG 10-36. A qualified subcontractor could not be located to perform the specified work within the project schedule. Therefore, these tasks have been added to the planned future investigation activities (see Section 5.0) of the Work Plan.

\section{C.1.2 Report Content}

This appendix is intended to provide information and data to support the corrective action investigation strategy described in the Site Characterization Work Plan. The content of this appendix is as follows:

- Section C.1.0 describes the investigation background, objectives, and the report content.

- Section C.2.0 provides information regarding the biological and cultural resource surveys.

- Section C.3.0 summarizes the results of the geophysical investigation and presents the data collected in map format.

- Section C.4.0 provides information regarding the sampling methods.

- Section C.5.0 summarizes the results of the laboratory analysis from the soil investigation of the SGZ area.

- Section C.6.0 provides a discussion on the results of the geophysical and soil sampling investigations of the SGZ area.

- Section C.7.0 discusses the quality assurance (QA) and QC procedures that were followed and the results of the QA and QC activities. 
- Section C.8.0 summarizes the significant results pertaining to the Gasbuggy preliminary field investigation.

- Section C.9.0 cites references used to prepare this appendix.

To make this report a concise summary, the complete field documentation and laboratory data (e.g., Field Activity Daily Logs, Sample Collection Logs, Analysis Request/Chain of Custody Forms, Visual Classification of Soils Forms, laboratory certificates of analyses, and analytical results) are not contained in this report. These documents are retained in project files as both hard copy files and electronic media. 


\section{C.2.0 Biological and Cultural Resources Surveys}

Biological and cultural resource surveys were completed for all operational areas excluding the SGZ area. Surveys for the SGZ area were completed in 1993 (DOE/NV, 1993a and b). These surveys were performed to ensure that future planned site characterization activities would not disturb sensitive species or sites of historical significance. Copies of the final reports for both surveys (TRC, 2000a and b) will be sent to the Jicarilla Ranger District of the Carson National Forest.

\section{C.2.1 Biological Survey}

The biological survey was completed on September 7, 2000. A detailed report on the findings of the survey was prepared and will be kept in the project files. The report concluded that "no affect will occur to any U.S. Fish and Wildlife Service (USFWS) threatened, endangered, proposed candidate, or species of concern as a result of environmental studies taking place at the Gasbuggy Site. No affect will occur to State of New Mexico threatened, endangered, or species of concern, or USFS sensitive species as a result of environmental studies at the Gasbuggy Site” (TRC, 2000a).

\section{C.2.2 Cultural Resources Survey}

The cultural resources survey was completed on September 22, 2000, by a contractor on the USFS Jicarilla Ranger district list of archeological permittees. A detailed report on the findings of the survey was prepared and will be kept in the project files. The survey identified three "isolated occurrences" (IOs) and one newly recorded "site". Isolated occurrences are archaeological manifestations offering limited information because they lack identifiable cultural context. Sites, generally speaking, are larger in size and extent. One IO was recorded at each of the following areas: Well GB-D area, RTP, and the HP. The "site" was recorded on the ridge to the south of the CP area. The report concluded that cultural resource monitoring is recommended should any future ground-disturbing work occur south of the road (TRC, 2000b). Although the documented boundaries of the "site" overlap the CP boundaries, no ground-disturbing work is planned within the specified "site" boundaries at the current time. 


\section{C.3.0 Geophysical Investigations}

Geophysical surveys were completed during August 2000 at all operational areas excluding the helicopter pad. Surveys were completed to locate and delineate shallow subsurface features.

\section{C.3.1 Scope and Objectives of Geophysical Investigation}

All shallow subsurface AOCs could not be accurately located exclusively through historical research and current site features. Therefore, a geophysical investigation was conducted to more accurately locate and delineate the known suspect shallow subsurface AOCs identified through the document search; locate other suspect areas; and map mud pits and subsurface features containing buried metal objects and/or debris such as landfills and septic tanks.

The geophysical surveys were conducted to accomplish the following objectives within each identified operational area:

\section{Ground Zero Area}

- Locate and delineate the drilling mud pits in the SGZ area associated with wells EPNG 10-36, GB-1, GB-2(R), GB-E(R), and GB-3.

- Locate the two septic tanks and potential associated influent and effluent lines (Figure 2-8).

- Locate and delineate undocumented landfills including the potential landfill identified along the western edge of the large mud pit (Landfill E) (Figure 2-5).

- Locate and delineate the landfills used to dispose of the drilling fluids and paraffin generated during the 1978 site restoration and well abandonment (Landfills A, C, and D) (Figure 2-9).

- Locate and delineate the "unused" decontamination pad and other concrete pads buried during the 1978 site restoration (Landfill B) (Figure 2-9).

- Locate and delineate undocumented subsurface features.

\section{Well GB-D Area}

- Locate and delineate the drilling mud pit.

- Locate and delineate undocumented subsurface features. 


\section{Recording Trailer Park}

- Locate and delineate the pit identified in Figure 2-10.

- Locate and delineate undocumented subsurface features.

\section{Control Point}

- Locate the septic tank and associated influent and effluent lines (Figure 2-13).

- Locate and delineate undocumented subsurface features.

No geophysical investigation was carried out at the helicopter pad. Based on a search of historical documents and process knowledge from other DOE/NV Offsites locations, there is no reason to suspect shallow subsurface features at this site.

\section{C.3.2 Demarcation of Geophysical Survey Areas}

Prior to conducting the geophysical investigation, the lateral limits of the survey area were marked and base grids were established for each operational area. Using the base grids as a reference, north-south and/or east-west oriented survey lanes were flagged. A base map was created by mapping surface objects that could potentially affect the geophysical data (e.g., roads, fences, well locations, project related equipment) and/or help locate anomalies based on surface features. These objects were accurately mapped using GPS.

\section{C.3.3 Data Acquisition and Processing}

Data was digitally recorded and periodically downloaded into a field computer for quality assurance and preliminary interpretation. All geophysical data was recorded in association with GPS data to accurately place identified anomalies. Field maps were then created by overlaying the base maps with the geophysical data.

Geophysical data was collected at the Gasbuggy Site using two EM methods (i.e., EM31 and EM61) and GPR. The EM31 surveys were conducted at each of the four areas. The EM61 surveys were used to further refine the location and limitations of metallic anomalies found at the SGZ area. The GPR was used to further refine the location and limitations of anomalies in all four areas of investigation (SAIC, 2000). 


\section{C.3.3.1 EM31}

The EM31 technology collects data on the electric and magnetic properties of subsurface materials. The "quadrature phase" measures differences in the conductivity of subsurface materials. The "inphase" reacts well to metal but not the natural conductivity of the earth. The technology measures to approximately $18 \mathrm{ft}$ bgs. Data was collected every 2 seconds or approximately every $2.5 \mathrm{ft}$ to $3 \mathrm{ft}$ while carrying the EM31 antenna over the surface while walking. The GPS antenna was also carried and positioning data was collected once every second while walking.

Prior to each survey, the lateral limits of the area to be surveyed were marked and base grids were established for each site. Using the base grids as a reference survey lanes were flagged. These lanes ensured that transects were evenly spaced. Survey control was maintained by using GPS technology (SAIC, 2000).

\section{C.3.3.2 EM61}

The EM61 is a high-resolution metal detection survey that uses an antenna to transmit an electromagnetic pulse into the subsurface and then uses a second antenna to measure the decay rate of the electromagnetic field. The magnitude of the remnant electromagnetic field provides a measurement of the metallic presence in the subsurface and the difference in the fields. The antenna are pulled across the surface on a frame supported by wheels. The EM61 data was collected over areas where landfills or other potential subsurface features which are suspected to contain metal. Survey lanes were established on 5-ft transects over the area of interest. Survey control was maintained by using GPS technology (SAIC, 2000).

\section{C.3.3.3 Ground-Penetrating Radar}

Ground-penetrating radar data is collected by pulling an antenna along the ground surface. An electromagnetic pulse (much higher in frequency then is used in the EM61) is sent into the subsurface. When there is a contrast in the dielectric permeativity of the subsurface materials, some of the energy is reflected back to the ground surface, where it is recorded. The GPR surveys were conducted to investigate anomalies detected during the EM31 survey and to attempt to identify the location of several septic tanks documented in historical reports (SAIC, 2000). 


\section{C.3.4 Results of Geophysical Investigation}

A detailed report on the results of the geophysical investigations is maintained in the project files (SAIC, 2000). The discussion and data presented here is a summary of this report.

\section{C.3.4.1 Surface Ground Zero Area}

A detailed discussion of the combined geophysical and soil sampling investigation results for the SGZ area is provided in Section C.6.0.

\section{C.3.4.2 Well GB-D Area}

The EM31 was used for an initial geophysical survey of the Well GB-D area. EM31 data indicated three significant anomalies in the quadrature phase. These anomalies are labeled A, B, and C on (Figure C.3-1). Additional data was collected for Anomalies A and C using GPR. Anomalies identified in the inphase were either attributed to known surface features (e.g., abandoned wellhead) or to isolated occurrences of shallow buried metal debris.

Based on the data from the geophysical investigations, process knowledge, and field observations, the following interpretations and conclusions were made:

- Anomaly A appears to be the mud pit used during the drilling of Well GB-D (Figure 2-5). Further investigation of this anomaly will be based on this information.

- Anomaly B is located near a soil pile suggesting the anomaly may represent an excavation and fill event. Further investigation of this anomaly will be based on this information.

- Anomaly C appears to be a natural feature of the area based on interpretation of the EM31 data and lack of anomalous response during GPR survey (SAIC, 2000). Neither historical information nor field observation indicate any reason to suspect contamination due to DOE activities in this specific area. Therefore, this anomaly will not be further investigated.

\section{C.3.4.3 Recording Trailer Park}

The EM31 was used for an initial geophysical survey of the RTP. EM31 data indicated seven significant anomalies in either the quadrature phase or the inphase. These anomalies are labeled A through G on Figure C.3-2 and/or Figure C.3-3. Additional data was collected for three of the anomalies (i.e., Anomalies A, C, and G) using GPR. 


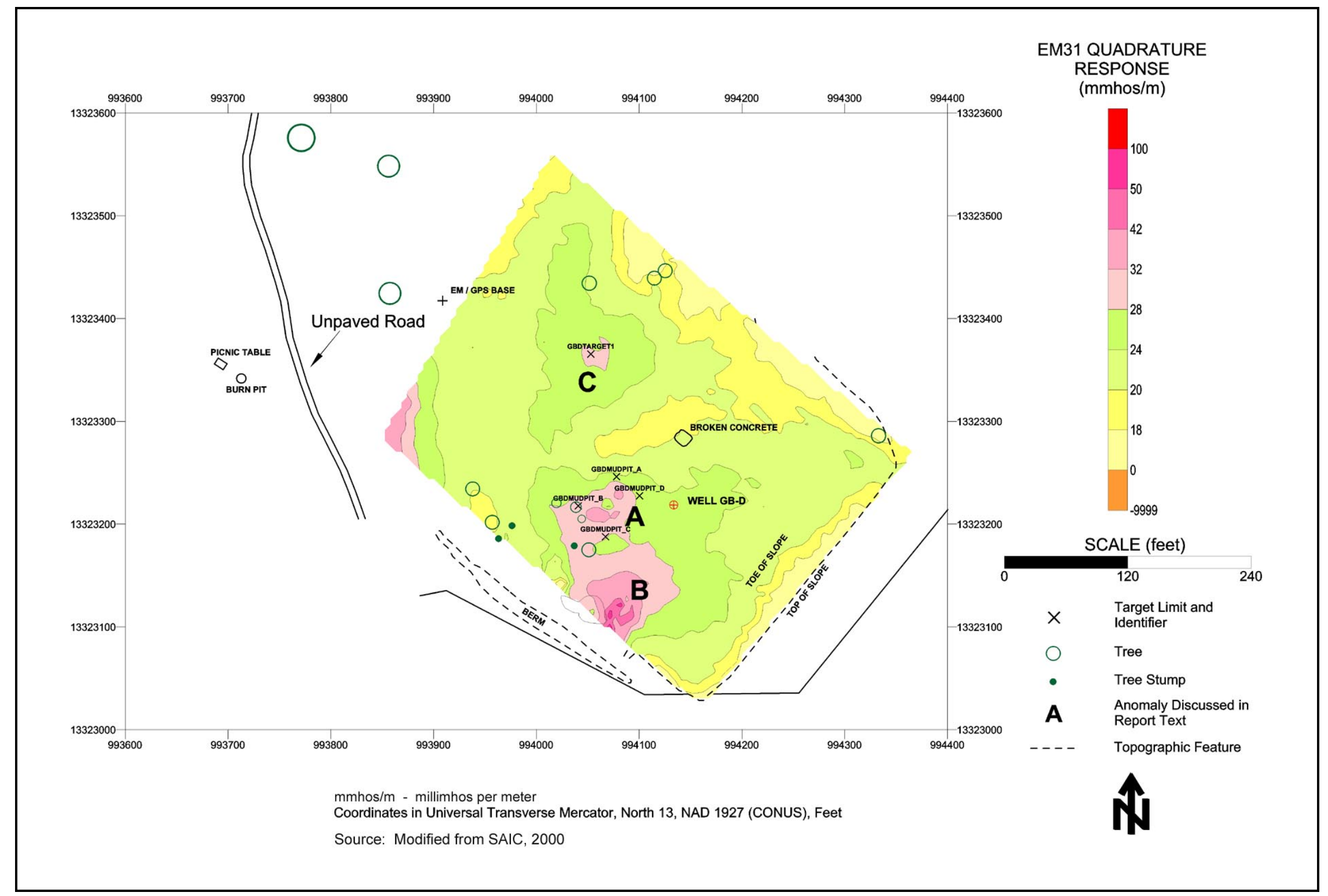

Figure C.3-1

Location of Anomalies Identified by EM31 Survey Quadrature Phase Response at the Well GB-D Area 


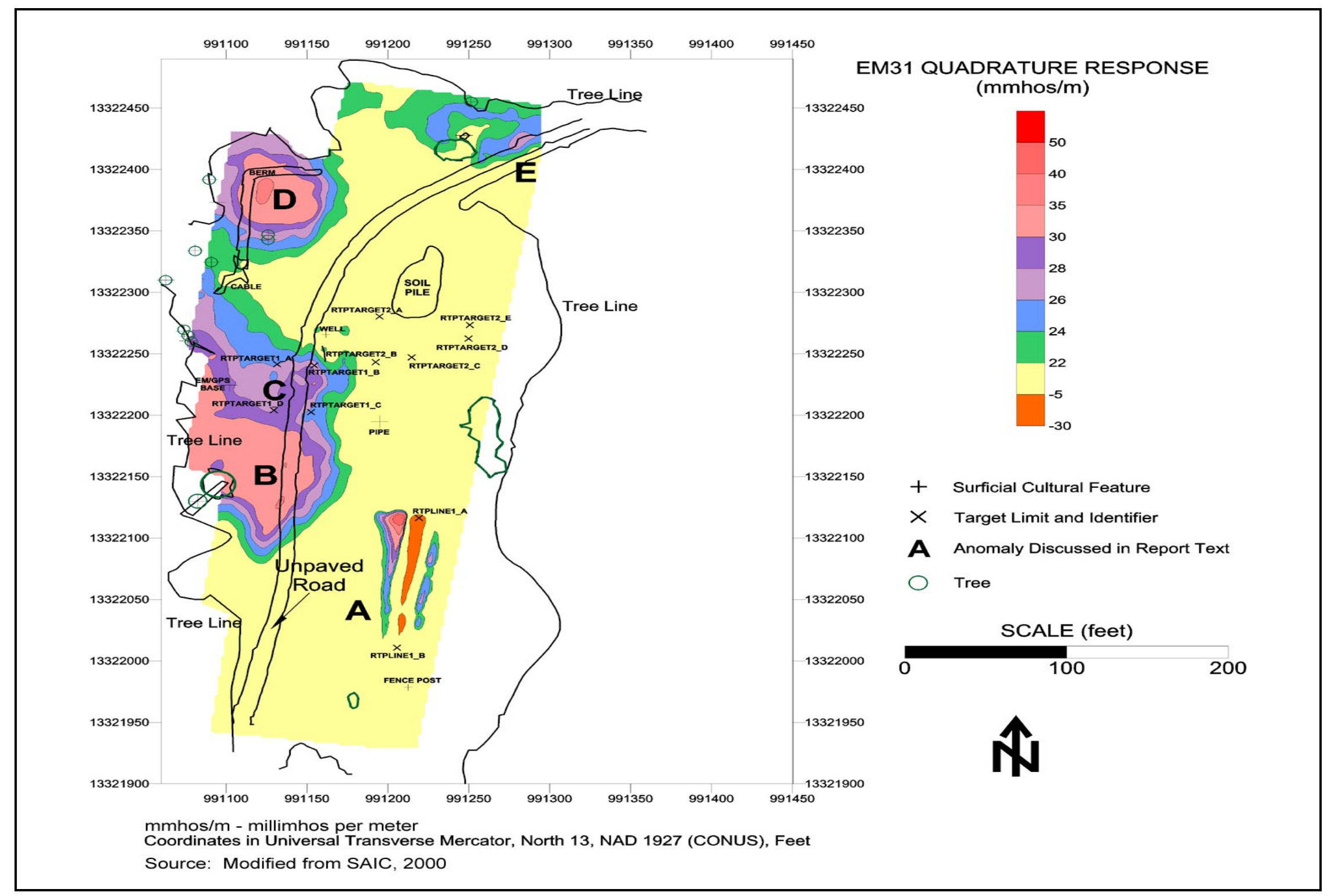

Figure C.3-2

Location of Anomalies Identified by EM31 Quadrature Phase Response at the Recording Trailer Park 


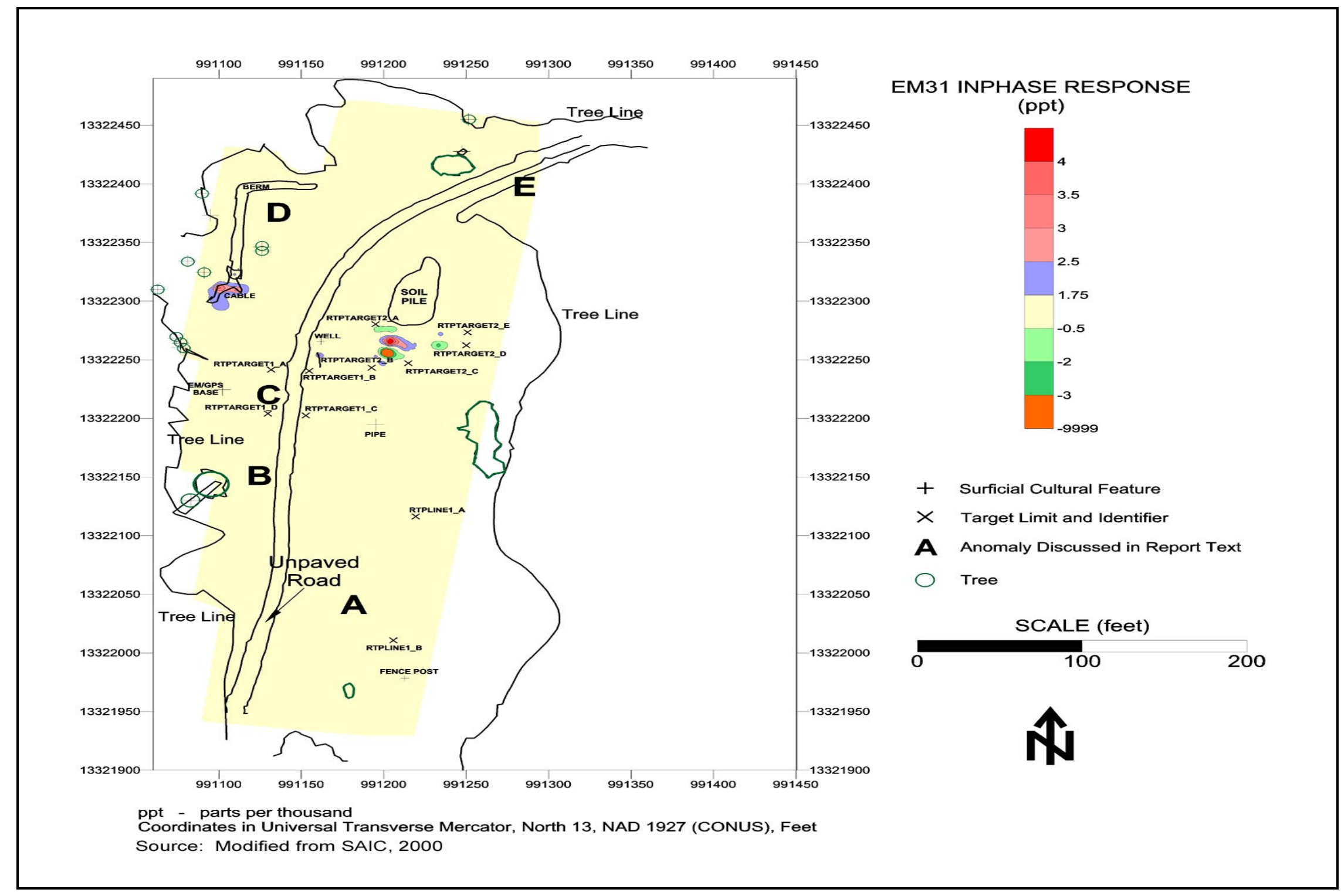

Figure C.3-3

Location of Anomalies Identified by EM31 Inphase Response at the Recording Trailer Park 
Based on the data from the geophysical investigations, process knowledge, and field observations, the following interpretations and conclusions were made:

- Anomaly A is linear and trends north to south. Based on the historical aerial photos of the RTP, this anomaly appears to be in the vicinity of the edge of the compacted earthen pad and driveway constructed at the site during the DOE presence (Figure 2-11). The anomaly may represent the edge of the pad. The GPR traverses perpendicular to this anomaly indicated no evidence of a subsurface pipe or cable. Neither historical information nor field observation indicate any reason to suspect contamination due to DOE activities in this specific area. Therefore, this anomaly will not be further investigated.

- Anomaly B is located along the western edge of the surveyed area in an area of higher elevation. The EM31 data are indicative of a natural feature associated with changes in soil electric properties and increased soil moisture (SAIC, 2000). Therefore, this anomaly will not be further investigated.

- Anomaly $\mathrm{C}$ is located due south of the abandoned natural gas well located on site. As indicated on the pipe marking the well, the well was operated by Meridian Oil and is referred to as San Juan 28-4. A search of the New Mexico Department of Natural Resources records indicates the well was completed in 1955. No abandonment date was found. An "existing" open pit is indicated on historic site drawings (Figure 2-10), and is visible in a historic photograph of the area (Figure 2-11). The GPR did not indicate any anomalies. The anomaly and the "existing" pit in the drawing are assumed to be the same feature (i.e, the sump associated with the on site well). Therefore, this anomaly will not be further investigated.

- Anomaly D is located near an L-shaped berm in the northwest corner of the area. The anomaly appears to represent a gradual change in conductivity as would a natural feature. The DOE activities at the RTP were concentrated in the southern portion of the cleared area (see Figure 2-10). The berm may be related to the natural gas well located approximately $100 \mathrm{ft}$ southeast of the berm. Neither historical information nor field observation indicate any reason to suspect contamination due to DOE activities in this specific area. Therefore, this anomaly will not be further investigated.

- Anomaly E is located adjacent to the dirt road at the entrance to the RTP. Based on interpretation of the geophysical results Anomaly E appears to be a natural feature of the area (SAIC, 2000). Therefore, this anomaly will not be further investigated.

- Anomaly F is located where steel cables are visible on the surface and is attributed to a response to these cables. The cables are likely related to the natural gas well located approximately $100 \mathrm{ft}$ southeast of the cables. Therefore, this anomaly will not be further investigated.

- Anomaly $\mathrm{G}$ is located near a soil pile suggesting the anomaly may represent an excavation and fill event. EM31 data indicated a strong metallic response and GPR traverses across this 
anomaly indicated numerous small hyperbolas, which may indicate buried metal cables. Further investigation of this anomaly will be based on this information.

\section{C.3.4.4 Control Point}

The EM31 was used for an initial geophysical survey of the CP. The EM31 data indicated five significant anomalies in the quadrature phase and/or the inphase. These anomalies are labeled A through E on Figure C.3-4 and/or Figure C.3-5. Additional anomalies were either attributed to known surface features (e.g., fence posts) or to isolated occurrences of shallow buried debris. Additional data was collected for two of the anomalies (i.e., Anomalies C and D) using GPR.

Based on the data from the geophysical investigations, process knowledge, and field observations, the following interpretations and conclusions were made:

- Anomaly A is located where site drawings indicate generators were located (Figure 2-13). The anomaly is assumed to be a response to a concrete pad that is visible at the location. Therefore, no further investigation is proposed for this anomaly.

- Anomaly B is located where site photographs and drawings indicate generators were located (see Figure 2-12 and Figure 2-13). Although no concrete pad is visible at the site surface, it may have been covered by erosion. The geophysical signature (i.e., strong negative response in both the EM31 quadrature phase and inphase) of this anomaly is similar to that of Anomaly A, which was attributed to a concrete pad. Therefore, no further investigation is proposed for this anomaly.

- Anomaly $\mathrm{C}$ is located in the vicinity where drawings indicate a septic tank (Figure 2-13). Numerous GPR traverses over this area indicated some man-made objects are present in the area, although the lack of continuity does not permit the interpretation of a septic tank or associated pipes (SAIC, 2000). Further investigation of this anomaly will be based on this information.

- Anomaly D is in the vicinity where the drawings indicate a leaching pipe for the septic tank (Figure 2-13). This group of small anomalies are nonmetallic and consistent with a clay pipe (SAIC, 2000) and or shallow buried pieces of broken up concrete. Therefore, no further investigation is proposed for this group of small anomalies.

- Anomaly $\mathrm{E}$ is in the vicinity of the southwest corner of the compacted earthen pad. The location and orientation of the anomaly may represent a man-made drainage feature as indicated in Figure 2-13. Due to the vicinity of this anomaly to the location of the mobile radiological laboratory as indicated in historical photos (Wofford, 2000), the origin of this anomaly will be further investigated. The notation "surface metal" south of Anomaly E is in 


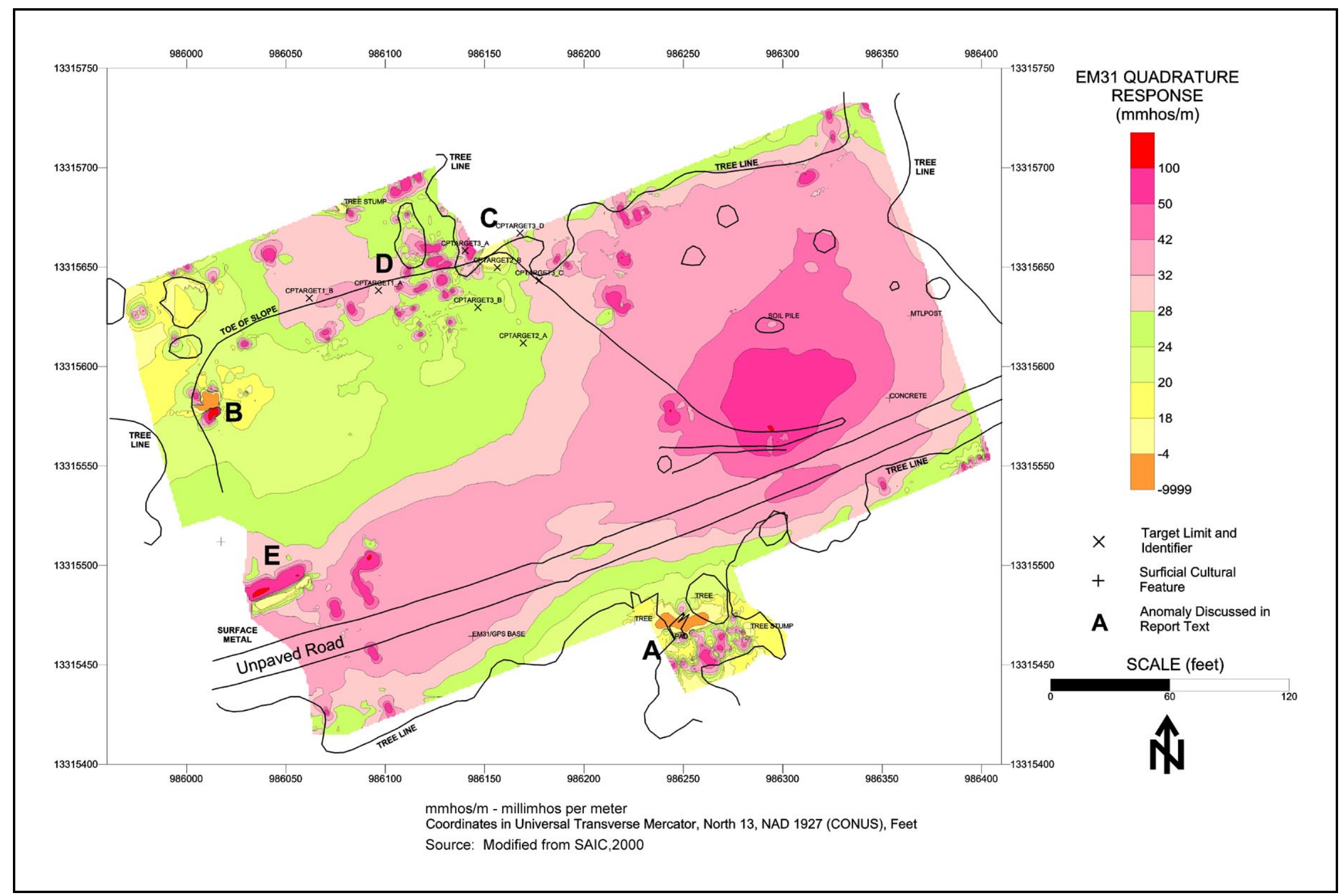

Figure C.3-4

Location of Anomalies Identified by EM31 Quadrature Phase Response at the Control Point 


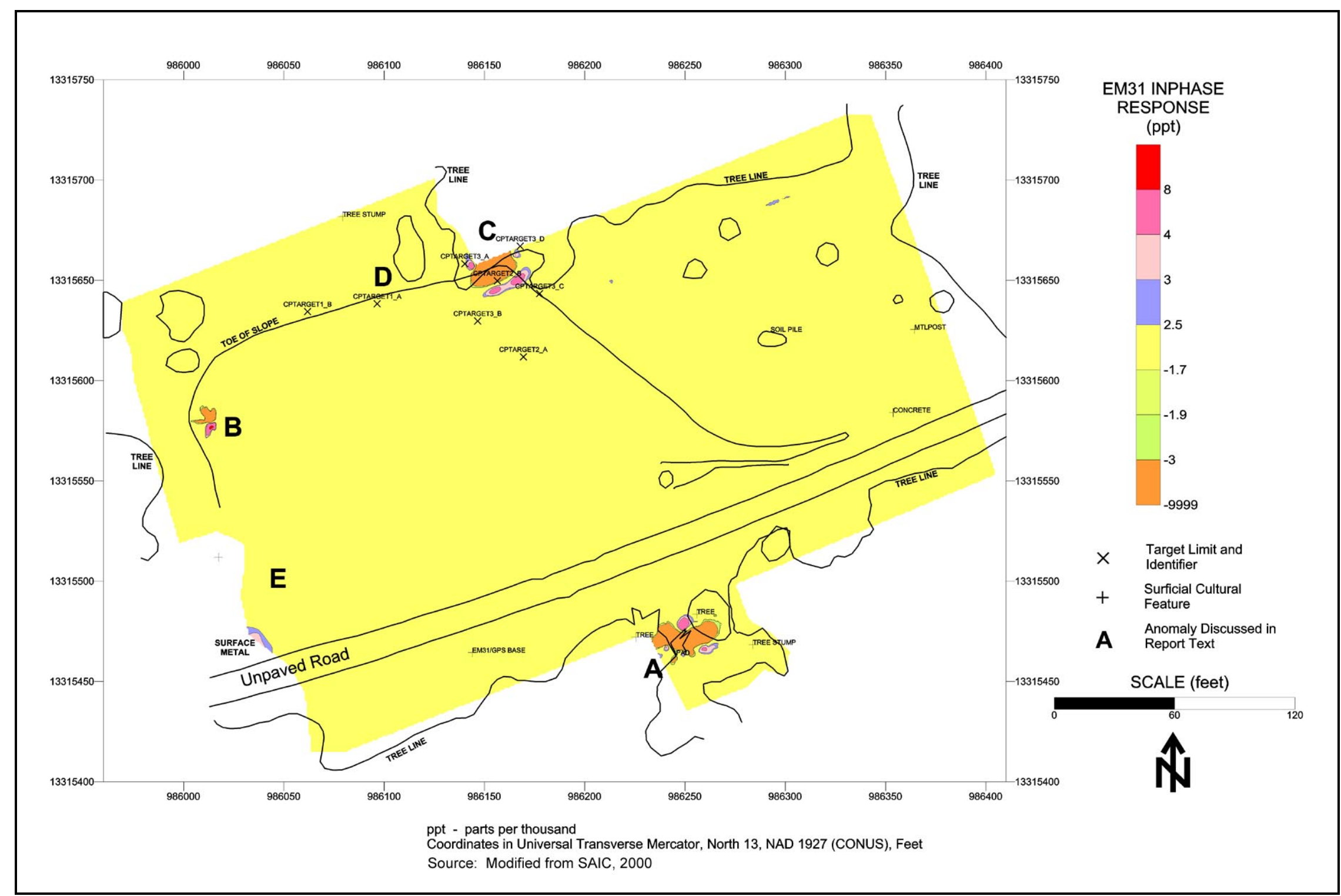

Figure C.3-5

Location of Anomalies Identified by EM31 Inphase Response at the Control Point 
reference to the location of a parked vehicle. The small "blip" in this location on the inphase figure (Figure C.3-5) is believed to be in response to this vehicle. 


\section{C.4.0 Sampling Activities}

Soil samples were collected exclusively from the SGZ area. Soil sampling was conducted in accordance with the NM QAPP presented in Appendix B. The samples were collected and documented by following approved sampling, chain of custody, and shipping procedures. Quality control samples (e.g., field blanks, equipment rinsate blanks, trip blanks, and sample duplicates) were collected as required by the NM QAPP and approved procedures.

\section{C.4.1 Site Description and Conditions}

The SGZ area is approximately 8 to10 acres in size. There are no buildings within the area. The only utility within the area is a underground gas pipeline that runs along the west side of USFS Road 357. Remaining surface features include four well markers, a ground water monitoring well (Well EPNG 10-36), a pipe stanchion, several concrete pads, and miscellaneous drilling rig anchors, fence posts, and other small historical features. Some soil berms and other surface contours from historical site activities are also still visible. There is a moderate amount of surface debris from historical site activities and recreational usage of the site.

\section{C.4.2 Direct-Push Operation}

Shallow subsurface soil samples were collected at 29 site characterization locations and 2 background locations by the direct-push method. All locations were biased based on the conceptual site model, historical knowledge, site features, and results of the geophysical investigation. The direct-push method works by mechanically pushing and/or hammering a core barrel into the soil to the desired depth. The core barrel used at the Gasbuggy Site was 48 in. long with an outside diameter of 2 in. The core barrel was lined with Lexan ${ }^{\mathrm{TM}}$ sleeves. Once brought to the surface, these sleeves were cut open along the length to allow for logging of soil type to the full depth of the borehole.

\section{C.4.3 Sample Collection}

The Lexan ${ }^{\mathrm{TM}}$ sleeve containing the recovered soil was removed from the direct-push equipment, the sleeve was capped, and the bottom cap was marked with the total depth. The sleeve was then brought to the sampling area and cut open. The core was screened for alpha and beta contamination with a 
NT Technologies Electra and gamma exposure rate measurements were collected with a Bicron microroentgen meter. The core was also screened for VOCs with a PID. Samples to be analyzed for volatile parameters were collected first using decontaminated stainless steel utensils to place soil directly into sample bottles from the specified depth. Samples to be analyzed for nonvolatile parameters were then collected by placing soil into decontaminated mixing bowls for homogenization prior to filling the required sample bottles.

The assigned sample numbers indicate the location and depth at which the sample was collected as indicated in Table C.4-1. Samples were generally collected from a 2-ft interval to obtain the required volume to fill the necessary sample bottles. Sample intervals were decreased in several cases to collect the sample in a desired interval based on soil characteristics. Sample intervals were also increased in several cases to obtain the required volume. Samples were collected at the depths specified in Table C.4-2.

Table C.4-1

Sample Identification Examples

\begin{tabular}{|c|c|c|}
\hline Sample Type & Example of Identification Number & Description \\
\hline \multirow{4}{*}{ Soil } & \multirow{4}{*}{$\begin{array}{c}\text { GBPS } 010406 \\
\text { or } \\
\text { GBPB } 010406\end{array}$} & GBP $=$ Gasbuggy Preliminary Investigation \\
\hline & & $\begin{array}{c}\text { S = Soil sample; or } \\
\mathrm{B}=\text { Background sample }\end{array}$ \\
\hline & & $01=$ Sequential boring number \\
\hline & & $\begin{array}{c}0406 \text { = Depth interval sample obtained } \\
(\text { e.g., 4-6 feet below ground surface) }\end{array}$ \\
\hline Duplicate Soil Sample & GBPS01 & $01=$ Sequential number for duplicate sample \\
\hline Source Blank & \multirow{4}{*}{ GBP001 } & \multirow{4}{*}{$001=$ Sequential number for $\mathrm{QA} / \mathrm{QC}$ samples } \\
\hline $\begin{array}{l}\text { Equipment Rinsate } \\
\text { Blank }\end{array}$ & & \\
\hline Trip Blank & & \\
\hline Field Blank & & \\
\hline
\end{tabular}


Table C.4-2

Sample Locations, Types, and Analyses

(Page 1 of 5)

\begin{tabular}{|c|c|c|c|c|}
\hline $\begin{array}{l}\text { Borehole } \\
\text { Number }^{\mathrm{a}}\end{array}$ & $\begin{array}{c}\text { Site Feature (soil samples) } \\
\text { or Sample Type }\end{array}$ & Sample Number ${ }^{c}$ & $\begin{array}{l}\text { Sample } \\
\text { Matrix }\end{array}$ & Analyses $^{d}$ \\
\hline \multirow{4}{*}{ GBP01 } & \multirow{4}{*}{$\begin{array}{l}\text { Well GB-2 Mud Pit and } \\
\text { Well GB-E Mud Pit D }\end{array}$} & GBPS010609 $^{\dagger}$ & $\overline{\text { Soil }}$ & $\overline{S S C, W Q C C, W C}$ \\
\hline & & GBPS010911 & Soil & SC, WQCC, WC \\
\hline & & GBPS011214 & Soil & SC \\
\hline & & GBPS011921 & Soil & SC \\
\hline \multirow{2}{*}{ GBP02 } & \multirow{2}{*}{ Well GB-2 Mud Pit } & GBPS020610 & Soil & SC, WQCC, WC \\
\hline & & GBPS021719 & Soil & SC \\
\hline \multirow{3}{*}{ GBP03 } & \multirow{3}{*}{ Well GB-E Mud Pit A } & GBPS030406 & Soil & SC, WQCC, WC \\
\hline & & GBPS030911 & Soil & SC \\
\hline & & GBPS031416 & Soil & $\mathrm{SC}$ \\
\hline \multirow{3}{*}{ GBP04 } & \multirow{3}{*}{ Landfill E } & GBPS040406 & Soil & SC, WQCC, WC \\
\hline & & GBPS040911 & Soil & SC \\
\hline & & GBPS041416 & Soil & SC \\
\hline \multirow{4}{*}{ GBP05 } & \multirow{4}{*}{ Landfill E } & GBPS050408 & Soil & SC, WQCC, WC \\
\hline & & GBPS051012 & Soil & SC \\
\hline & & GBPS051820 & Soil & SC \\
\hline & & GBPS01 & Soil & Duplicate of above \\
\hline \multirow{3}{*}{ GBP06 } & \multirow{3}{*}{ Well EPNG 10-36 Sump } & GBPS060608 & Soil & SC, WQCC, WC \\
\hline & & GBPS061012 & Soil & SC \\
\hline & & GBPS061618 & Soil & SC \\
\hline \multirow{3}{*}{ GBP07 } & \multirow{3}{*}{ Well GB-E Mud Pit E } & GBPS070608 & Soil & SC, WQCC, WC \\
\hline & & GBPS071012 & Soil & SC \\
\hline & & GBPS071618 & Soil & SC \\
\hline \multirow{2}{*}{ GBP08 } & \multirow{2}{*}{ Well GB-1 Drill Pad } & GBPS080204 & Soil & $\mathrm{SC}$ \\
\hline & & GBPS081416 & Soil & $\mathrm{SC}$ \\
\hline \multirow{2}{*}{ GBP09 } & \multirow{2}{*}{ Well GB-1 Drill Pad } & GBPS090204 & Soil & SC \\
\hline & & GBPS091416 & Soil & SC \\
\hline \multirow{2}{*}{ GBP10 } & \multirow{2}{*}{ Well GB-1 Drill Pad } & GBPS100204 & Soil & SC, WQCC, WC \\
\hline & & GBPS101416 & Soil & SC \\
\hline \multirow{2}{*}{ GBP11 } & \multirow{2}{*}{ Well GB-E Drill Pad } & GBPS110204 & Soil & SC, WQCC, WC \\
\hline & & GBPS111416 & Soil & SC \\
\hline
\end{tabular}


Table C.4-2

Sample Locations, Types, and Analyses

(Page 2 of 5 )

\begin{tabular}{|c|c|c|c|c|}
\hline $\begin{array}{l}\text { Borehole } \\
\text { Number }^{\mathrm{a}}\end{array}$ & $\begin{array}{c}\text { Site Feature (soil samples) } \\
\text { or Sample Type }\end{array}$ & Sample Number ${ }^{c}$ & $\begin{array}{l}\text { Sample } \\
\text { Matrix }\end{array}$ & Analyses $^{d}$ \\
\hline \multirow{3}{*}{ GBP12 } & \multirow{3}{*}{ Well GB-1 Mud Pit } & GBPS120204 $^{f}$ & $\overline{\text { Soil }}$ & SC, WQCC, WC \\
\hline & & GBPS120608 & Soil & SC \\
\hline & & GBPS121719 & Soil & SC \\
\hline GBP13 & Well GB-E Mud Pit $A^{g}$ & GBPS131920 & Soil & $\mathrm{SC}$ \\
\hline \multirow{5}{*}{ GBP14 } & \multirow{5}{*}{ flare stack area } & GBPS140304 & Soil & Tritium \\
\hline & & GBPS140708 & Soil & Tritium \\
\hline & & GBPS141112 & Soil & Tritium \\
\hline & & GBPS141516 & Soil & Tritium \\
\hline & & GBPS141920 & Soil & Tritium \\
\hline \multirow{2}{*}{ GBP15 } & \multirow{2}{*}{ Well EPNG 10-36 Drill Pad } & GBPS150204 & Soil & SC \\
\hline & & GBPS151416 & Soil & $\mathrm{SC}$ \\
\hline \multirow{3}{*}{ GBP16 } & \multirow{3}{*}{ Well EPNG 10-36 Drill Pad } & GBPS160204 & Soil & SC \\
\hline & & GBPS02 & Soil & Duplicate of above \\
\hline & & GBPS161416 & Soil & SC \\
\hline \multirow{3}{*}{ GBP17 } & \multirow{3}{*}{ Well EPNG 10-36 Drill Pad } & GBPS170204 & Soil & SC, WQCC, WC \\
\hline & & GBPS171314 & Soil & SC \\
\hline & & GBPS172123 & Soil & SC \\
\hline \multirow{4}{*}{ GBP18 } & \multirow{4}{*}{ Well GB-E Mud Pit E } & GBPS180608 & Soil & $\mathrm{SC}$ \\
\hline & & GBPS180911 & Soil & SC, WQCC, WC \\
\hline & & GBPS181416 & Soil & SC \\
\hline & & GBPS182122 & Soil & SC \\
\hline \multirow{2}{*}{ GBP19 } & \multirow{2}{*}{ Well GB-3 Drill Pad } & GBPS190204 & Soil & SC \\
\hline & & GBPS191416 & Soil & SC \\
\hline \multirow{2}{*}{ GBP20 } & \multirow{2}{*}{ Well GB-3 Drill Pad } & GBPS200204 & Soil & SC \\
\hline & & GBPS201416 & Soil & SC \\
\hline \multirow{3}{*}{ GBP21 } & \multirow{3}{*}{ Well GB-2 Drill Pad } & GBPS210204 & Soil & SC, WQCC, WC \\
\hline & & GBPS210608 & Soil & $\mathrm{SC}$ \\
\hline & & GBPS211416 & Soil & $\mathrm{SC}$ \\
\hline \multirow{4}{*}{ GBP22 } & \multirow{4}{*}{ Well GB-2 Drill Pad } & GBPS220204 & Soil & SC \\
\hline & & GBPS221416 & Soil & SC \\
\hline & & GBPS03 & Soil & Duplicate of above \\
\hline & & GBPS222021 & Soil & $\mathrm{SC}$ \\
\hline
\end{tabular}


Table C.4-2

Sample Locations, Types, and Analyses

(Page 3 of 5)

\begin{tabular}{|c|c|c|c|c|}
\hline $\begin{array}{l}\text { Borehole } \\
\text { Number }\end{array}$ & $\begin{array}{c}\text { Site Feature (soil samples) } \\
\text { or Sample Type }^{\mathrm{b}}\end{array}$ & Sample Number ${ }^{c}$ & $\begin{array}{l}\text { Sample } \\
\text { Matrix }\end{array}$ & Analyses $^{d}$ \\
\hline \multirow{5}{*}{ GBP23 } & \multirow{5}{*}{ water/gas separator area } & GBPS230304 & $\overline{\text { Soil }}$ & Tritium \\
\hline & & GBPS230708 & Soil & Tritium \\
\hline & & GBPS231112 & Soil & Tritium \\
\hline & & GBPS231516 & Soil & Tritium \\
\hline & & GBPS231920 & Soil & Tritium \\
\hline \multirow{4}{*}{ GBP24 } & \multirow{4}{*}{ Well GB-E Mud Pit A } & GBPS240304 & Soil & Tritium \\
\hline & & GBPS240506 & Soil & SC, Tritium \\
\hline & & GBPS241112 & Soil & Tritium \\
\hline & & GBPS241416 & Soil & SC, Tritium \\
\hline \multirow{4}{*}{ GBP25 } & \multirow{4}{*}{ flare stack area } & GBPS250304 & Soil & Tritium \\
\hline & & GBPS250507 & Soil & SC \\
\hline & & GBPS250708 & Soil & Tritium \\
\hline & & GBPS251012 & Soil & SC, Tritium \\
\hline \multirow{3}{*}{ GBP26 } & \multirow{3}{*}{ Well GB-E Drill Pad } & GBPS260204 & Soil & $\mathrm{SC}$ \\
\hline & & GBPS261416 & Soil & SC \\
\hline & & GBPS04 & Soil & Duplicate of above \\
\hline \multirow{2}{*}{ GBP27 } & \multirow{2}{*}{ Well GB-E Drill Pad } & GBPS270204 & Soil & $\mathrm{SC}$ \\
\hline & & GBPS271416 & Soil & SC \\
\hline \multirow{5}{*}{ GBP28 } & \multirow{5}{*}{$\begin{array}{c}\text { berm that separates the Well } \\
\text { GB-E Mud Pit A and the } \\
\text { Well GB-2 Mud Pit }\end{array}$} & GBPS280608 & Soil & SC \\
\hline & & GBPS281012 & Soil & $\mathrm{SC}$ \\
\hline & & GBPS282224 & Soil & SC \\
\hline & & GBPS283032 & Soil & SC \\
\hline & & GBPS283436 & Soil & SC \\
\hline \multirow{2}{*}{ GBP29 } & \multirow{2}{*}{ Well GB-1 Mud Pit } & GBPS290103 & Soil & SC \\
\hline & & GBPS291416 & Soil & SC \\
\hline \multirow{2}{*}{ GBPB01 } & \multirow{2}{*}{ background } & GBPB010204 & Soil & BG, VOCs \\
\hline & & GBPB010912 & Soil & BG, VOCs \\
\hline \multirow{3}{*}{ GBPB03 } & \multirow{3}{*}{ background } & GBPB030407 & Soil & $B G$ \\
\hline & & GBPB031012 & Soil & $B G$ \\
\hline & & GBPB031416 & Soil & $B G$ \\
\hline NA & trip blank & GBP001 & Water & VOCs \\
\hline NA & trip blank & GBP002 & Water & VOCs \\
\hline
\end{tabular}


Table C.4-2

Sample Locations, Types, and Analyses

(Page 4 of 5)

\begin{tabular}{|c|c|c|c|c|}
\hline $\begin{array}{l}\text { Borehole } \\
\text { Number }^{\mathrm{a}}\end{array}$ & $\begin{array}{c}\text { Site Feature (soil samples) } \\
\text { or Sample Type }\end{array}$ & Sample Number ${ }^{c}$ & $\begin{array}{l}\text { Sample } \\
\text { Matrix }\end{array}$ & Analyses $^{d}$ \\
\hline$\overline{N A}$ & trip blank & GBP003 & Water & VOCs \\
\hline NA & trip blank & GBP004 & Water & VOCs \\
\hline NA & trip blank & GBP005 & Water & VOCs \\
\hline NA & trip blank & GBP006 & Water & VOCs \\
\hline NA & trip blank & GBP007 & Water & VOCs \\
\hline NA & trip blank & GBP008 & Water & VOCs \\
\hline NA & trip blank & GBP009 & Water & VOCs \\
\hline NA & field blank & GBP010 & Water & $\begin{array}{l}\mathrm{SC}, \mathrm{WQCC} \text { (except for } \\
\left.\mathrm{NO}_{3}, \mathrm{Br}, \mathrm{Cl}, \mathrm{F} \text {, and } \mathrm{SO}_{4}\right) \\
\text { tritium }\end{array}$ \\
\hline NA & trip blank & GBP011 & Water & VOCs \\
\hline NA & equipment rinsate blank & GBP012 & Water & $\begin{array}{l}\mathrm{SC}, \mathrm{WQCC} \text { (except for } \\
\left.\mathrm{NO}_{3}, \mathrm{Br}, \mathrm{Cl}, \mathrm{F} \text {, and } \mathrm{SO}_{4}\right), \\
\text { tritium }\end{array}$ \\
\hline NA & trip blank & GBP013 & Water & VOCs \\
\hline NA & trip blank & GBP014 & Water & VOCs \\
\hline NA & $\begin{array}{c}\text { source blank for } \\
\text { decontamination water }\end{array}$ & GBP015 & Water & SC, WQCC, tritium \\
\hline NA & trip blank & GBP016 & Water & VOCs \\
\hline NA & $\begin{array}{l}\text { source blank for Lexan }{ }^{\mathrm{TM}} \\
\text { tube }^{\mathrm{i}}\end{array}$ & GBP017 & Water & SC, WQCC, tritium \\
\hline NA & trip blank & GBP018 & Water & VOCs \\
\hline NA & equipment rinsate blank & GBP019 & Water & $\mathrm{NO}_{3}, \mathrm{Br}, \mathrm{Cl}, \mathrm{F}$, and $\mathrm{SO}_{4}^{\mathrm{j}}$ \\
\hline NA & trip blank & GBP020 & Water & VOCs \\
\hline NA & trip blank & GBP021 & Water & VOCs \\
\hline NA & trip blank & GBP022 & Water & VOCs \\
\hline NA & field blank & GBP023 & Water & VOCs, WQCC, Tritium \\
\hline NA & trip blank & GBP024 & Water & VOCs \\
\hline NA & field blank & GBP025 & Water & SC, WQCC, tritium \\
\hline NA & trip blank & GBP026 & Water & VOCs \\
\hline NA & trip blank & GBP027 & Water & VOCs \\
\hline NA & field blank & GBP028 & Water & SC, WQCC, tritium \\
\hline NA & trip blank & GBP029 & Water & VOCs \\
\hline NA & $\begin{array}{c}\text { source blank for Lexan }{ }^{\mathrm{TM}} \\
\text { tube }\end{array}$ & GBP030 & Water & SC, WQCC, tritium \\
\hline
\end{tabular}


Table C.4-2

Sample Locations, Types, and Analyses

(Page 5 of 5 )

\begin{tabular}{|c|c|c|c|c|}
\hline $\begin{array}{c}\text { Borehole } \\
\text { Number }^{\text {a }}\end{array}$ & $\begin{array}{c}\text { Site Feature (soil samples) } \\
\text { or Sample Type }^{\text {b }}\end{array}$ & Sample Number & $\begin{array}{c}\text { Sample } \\
\text { Matrix }\end{array}$ & Analyses $^{\text {d }}$ \\
\hline \hline NA & trip blank & GBP031 & Water & VOCs \\
\hline NA & trip blank & GBP032 & Water & VOCs \\
\hline
\end{tabular}

${ }^{a}$ The alphanumerical characters indicated that the borehole was drilled during the Gasbuggy preliminary investigation (GBP) which occurred in August-September of 2000, if it is a background borehole (GBPB), and the sequential boring number.

bIf sample matrix is soil, the description in this column describes the site features (e.g., mud pit, landfill) that the samples from the borehole were intended to capture.

'See Table C.4-1 for an explanation of the sample nomenclature.

dSee explanation of abbreviations below for the specific analysis.

${ }^{\mathrm{e}}$ The Well GB-E Mud Pit D is located within the bounds of the Well GB-2 Mud Pit and appears to overlay the Well GB-2 Mud Pit.

fVisual observation of the soil core indicates this sample was collected from a suspect drilling mud layer.

gVisual observation of the soil core did not indicate a layer of drilling mud within this borehole.

${ }^{\mathrm{h}} \mathrm{NO}_{3}, \mathrm{Br}, \mathrm{Cl}, \mathrm{F}$, and $\mathrm{SO}_{4}$ were not collected because the hold time for $\mathrm{NO}_{3}$ is 48 hours, and since the sample was collected on Saturday it would not have been analyzed on time.

'Two different types of Lexan ${ }^{\mathrm{TM}}$ tubes were used to line the sample core. Samples were collected by pouring deionized water through the tube.

${ }^{\mathrm{i}} \mathrm{NO}_{3}, \mathrm{Br}, \mathrm{Cl}, \mathrm{F}$, and $\mathrm{SO}_{4}$ were the only parameters collected in order to make up for them not being collected for sample GBP012.

SC = Site Characterization parameters are: total VOCs, total SVOCs, TAL metals, boron, molybdenum, uranium, TPH (diesel-range organics [DRO] and gasoline-range organics [GRO]).

WQCC $=$ New Mexico Water Quality Control Commission parameters are: nitrates $\left(\mathrm{NO}_{3}\right)$, cyanide, bromide $(\mathrm{Br})$, chloride $(\mathrm{Cl})$, fluoride $(\mathrm{F})$, sulfate $\left(\mathrm{SO}_{4}\right)$, radium-226 and radium-228

WC $=$ Waste Characterization parameters are: TCLP metals, TCLP VOCs, TCLP SVOCS, and Tritium.

$\mathrm{NO}_{3}=$ Nitrates

$\mathrm{Br}=$ Bromide

$\mathrm{Cl}=$ Chloride

$\mathrm{F}=$ Fluoride

$\mathrm{SO}_{4}=$ Sulfate

$\mathrm{BG}$ = Background parameters are: TAL metals, boron, molybdenum, uranium, total SVOCs, cyanide, $\mathrm{Br}, \mathrm{Cl}, \mathrm{F}, \mathrm{SO}_{4}, \mathrm{NO}_{3}$, and radium-226/-228

NA $=$ Not applicable

\section{C.4.4 Waste Management}

Eight drums of investigation-derived waste were generated during the investigation. The waste was characterized as sanitary (i.e., nonhazardous and nonradioactive). All waste was shipped to a licensed disposal facility.

\section{C.4.5 Geology}

The natural contour of the site slopes northeast into Leandro Canyon. Leandro Canyon is an ephemeral drainage and tributary of the ephemeral La Jara Creek. 
Field descriptions performed by the field geologist for each boring were recorded on a Visual Classification of Soil Log. The stratigraphy is dominated by poorly graded red-brown to brown silty sand, poorly graded sand, and silt to a minimum of $30 \mathrm{ft}$ bgs. The maximum depth of any boring was $36 \mathrm{ft}$ bgs. Occasional clay layers exist at depths varying from 2 to $20 \mathrm{ft}$ bgs. Bentonite chips were discovered interspersed in some of the borings. These chips are likely a product of the historic drilling operations at the site. Weathered sandstone bedrock was encountered between 14 to $24 \mathrm{ft}$ bgs in a few of the borings in the northwest portion of the site.

\section{C.4.6 Hydrology}

No groundwater was encountered during the preliminary field investigation. Maximum depth of boreholes was $36 \mathrm{ft}$ bgs. 


\section{C.5.0 Gasbuggy Preliminary Investigation Soil Sample Results}

The analytical results of samples collected during the Gasbuggy preliminary field investigation have been compiled and summarized in the following subsections. The parameters analyzed for in this investigation are presented in Table C.4-2. The laboratory analytical methods utilized for this investigation are presented in Appendix B.

Samples were analyzed at Paragon Analytics in Fort Collins, Colorado. Complete analytical results are retained in project files as both hard copy files and electronic media.

\section{C.5.1 Site Characterization Parameters}

The site characterization parameters (i.e., TPH [DRO, GRO], VOCs, SVOCs, RCRA metals, and tritium) were selected through the application of site knowledge using the EPA's Guidance for the Data Quality Objectives Process (EPA, 1994a). The PALs for these parameters (i.e., the Region IX Industrial Soil PRGs [EPA, 1999a]) are presented in association with the results for these analyses. The results will be used as necessary to formulate corrective action decisions and/or as part of a risk assessment, if necessary.

\section{C.5.1.1 Total Petroleum Hydrocarbon Analytical Results}

The TPH analytical results are provided in Table C.5-1. Analytical results show that seven samples have TPH values greater than 100 milligrams per kilogram $(\mathrm{mg} / \mathrm{kg})$ indicating a significant detection. All of the samples in which TPH was detected above $100 \mathrm{mg} / \mathrm{kg}$, except for two, were collected from a layer of drilling mud identified by visual observation within the mud pits. The exceptions (i.e., GBPS250507 and GBPS280608) were both collected from the berm that separates the Well GB-2 Mud Pit from Well GB-E Mud Pit A. The flare stack was located at the northern end of this berm. Based on visual observation, this berm appears to have been constructed at least partially by pushing up drill cuttings and drilling mud from the mud pits. These two samples were also the only two in which gasoline was detected at concentrations greater than $100 \mathrm{mg} / \mathrm{kg}$. The source of the gasoline is not known. In all cases where TPH was detected at levels greater than $100 \mathrm{mg} / \mathrm{kg}$, a sample collected at a lower depth in the same borehole indicated a TPH concentration of less than $100 \mathrm{mg} / \mathrm{kg}$ and/or a nondetect. 
Table C.5-1

Soil Sample Results for TPH

(Page 1 of 3 )

\begin{tabular}{|c|c|c|c|}
\hline \multirow{2}{*}{ Borehole Location } & \multirow{2}{*}{ Sample Number } & \multicolumn{2}{|c|}{ Contaminants of Potential Concern $(\mathrm{mg} / \mathrm{kg})$} \\
\hline & & Diesel & Gasoline \\
\hline \multirow{4}{*}{$\begin{array}{l}\text { Well GB-2 Mud Pit } \\
\text { and Well GB-E } \\
\text { Mud Pit } D^{a}\end{array}$} & GBPS010609 $^{b}$ & $2,100(J)$ & 3.1 \\
\hline & GBPS010911 & 270 & 1.6 \\
\hline & GBPS011214 & $5.9(U)$ & $0.59(U)$ \\
\hline & GBPS011921 & 27 & $0.57(U)$ \\
\hline \multirow{2}{*}{ Well GB-2 Mud Pit } & GBPS020610 & 300 & $0.041(\mathrm{~J})$ \\
\hline & GBPS021719 & $5.9(U)$ & $0.59(U)$ \\
\hline \multirow{3}{*}{ Well GB-E Mud Pit A } & GBPS030406 & $720(\mathrm{~J})$ & $0.58(U)$ \\
\hline & GBPS030911 & $5.6(U)$ & $0.56(U)$ \\
\hline & GBPS031416 & $5.6(U)$ & $0.56(U)$ \\
\hline \multirow{3}{*}{ Landfill E } & GBPS040406 & $5.7(U)$ & $0.57(U)$ \\
\hline & GBPS040911 & $5.5(U)$ & $0.55(U)$ \\
\hline & GBPS041416 & $5.6(U)$ & $0.56(\mathrm{UJ})$ \\
\hline \multirow{4}{*}{ Landfill E } & GBPS050408 & $5.8(U)$ & $0.58(U)$ \\
\hline & GBPS051012 & $5.3(U)$ & $0.53(U)$ \\
\hline & GBPS051820 & $5.5(U)$ & $0.55(U)$ \\
\hline & GBPSO $01^{c}$ & $5.5(U)$ & $0.55(\mathrm{U})$ \\
\hline \multirow{3}{*}{$\begin{array}{c}\text { Well EPNG 10-36 } \\
\text { Sump }\end{array}$} & GBPS060608 & 8.2 & $0.52(U)$ \\
\hline & GBPS061012 & $6.4(U)$ & $0.53(U)$ \\
\hline & GBPS061618 & $6.3(\mathrm{U})$ & $0.58(U)$ \\
\hline \multirow{3}{*}{ Well GB-E Mud Pit E } & GBPS070608 ${ }^{\mathrm{b}}$ & $5.7(U)$ & $0.57(\mathrm{U})$ \\
\hline & GBPS071012 & $7.6(U)$ & $0.57(U)$ \\
\hline & GBPS071618 & $5.6(U)$ & $0.56(U)$ \\
\hline \multirow{2}{*}{ Well GB-1 Drill Pad } & GBPS080204 & $5.2(U)$ & $0.52(U)$ \\
\hline & GBPS081416 & $5.5(U)$ & $0.55(U)$ \\
\hline \multirow{2}{*}{ Well GB-1 Drill Pad } & GBPS090204 & $5.4(U)$ & $0.54(U)$ \\
\hline & GBPS091416 & $5.3(U)$ & $0.53(U)$ \\
\hline \multirow{2}{*}{ Well GB-1 Drill Pad } & GBPS100204 & $5.6(U)$ & $0.56(U)$ \\
\hline & GBPS101416 & $5.7(\mathrm{U})$ & $0.57(\mathrm{U})$ \\
\hline
\end{tabular}


Table C.5-1

Soil Sample Results for TPH

(Page 2 of 3 )

\begin{tabular}{|c|c|c|c|}
\hline \multirow{2}{*}{ Borehole Location } & \multirow{2}{*}{ Sample Number } & \multicolumn{2}{|c|}{ Contaminants of Potential Concern $(\mathrm{mg} / \mathrm{kg})$} \\
\hline & & Diesel & Gasoline \\
\hline \multirow{2}{*}{ Well GB-E Drill Pad } & GBPS110204 & $5.5(U)$ & $0.55(U)$ \\
\hline & GBPS111416 & $5.7(U)$ & $0.57(U)$ \\
\hline \multirow{3}{*}{ Well GB-1 Mud Pit } & GBPS120204 ${ }^{b}$ & $5.5(U)$ & $0.55(U)$ \\
\hline & GBPS120608 & $6.1(U)$ & $0.54(U)$ \\
\hline & GBPS121719 & $6.3(U)$ & $0.58(U)$ \\
\hline Well GB-E Mud Pit A & GBPS131920 & $5.6(U)$ & $0.56(U)$ \\
\hline \multirow{2}{*}{$\begin{array}{l}\text { Well EPNG 10-36 } \\
\text { Drill Pad }\end{array}$} & GBPS150204 & $5.2(U)$ & $0.52(U)$ \\
\hline & GBPS151416 & $5.8(U)$ & $0.58(U)$ \\
\hline \multirow{3}{*}{$\begin{array}{c}\text { Well EPNG 10-36 } \\
\text { Drill Pad }\end{array}$} & GBPS160204 & $5.2(U)$ & $0.52(\mathrm{UJ})$ \\
\hline & $\mathrm{GBPSO}^{\mathrm{c}}$ & $5.2(U)$ & $0.52(U)$ \\
\hline & GBPS161416 & $6.3(U)$ & $0.58(U)$ \\
\hline \multirow{3}{*}{$\begin{array}{c}\text { Well EPNG 10-36 } \\
\text { Drill Pad }\end{array}$} & GBPS170204 & $5.3(U)$ & $0.53(U)$ \\
\hline & GBPS171314 & $5.4(U)$ & $0.54(U)$ \\
\hline & GBPS172123 & $5.6(U)$ & $0.56(U)$ \\
\hline \multirow{4}{*}{ Well GB-E Mud Pit E } & GBPS180608 & $14(U)$ & $0.55(U)$ \\
\hline & GBPS180911 & 10 & $0.68(U)$ \\
\hline & GBPS181416 & $5.4(U)$ & $0.54(U)$ \\
\hline & GBPS182122 & $5.9(U)$ & $0.59(U)$ \\
\hline \multirow{2}{*}{ Well GB-3 Drill Pad } & GBPS190204 & $5.4(U)$ & 0.54 (UJ) \\
\hline & GBPS191416 & $5.9(U)$ & $0.53(U)$ \\
\hline \multirow{2}{*}{ Well GB-3 Drill Pad } & GBPS200204 & $7.5(U)$ & $0.53(U)$ \\
\hline & GBPS201416 & $5.6(U)$ & $0.56(U)$ \\
\hline \multirow{3}{*}{ Well GB-2 Drill Pad } & GBPS210204 & $5.5(U)$ & $0.55(U)$ \\
\hline & GBPS210608 & $5.3(U)$ & $0.53(U)$ \\
\hline & GBPS211416 & $6.4(U)$ & $0.58(U)$ \\
\hline
\end{tabular}


Table C.5-1

Soil Sample Results for TPH

(Page 3 of 3)

\begin{tabular}{|c|c|c|c|}
\hline \multirow{2}{*}{ Borehole Location } & \multirow{2}{*}{ Sample Number } & \multicolumn{2}{|c|}{ Contaminants of Potential Concern $(\mathrm{mg} / \mathrm{kg})$} \\
\hline & & Diesel & Gasoline \\
\hline \multirow{4}{*}{ Well GB-2 Drill Pad } & GBPS220204 & $5.6(U)$ & $0.56(U)$ \\
\hline & GBPS221416 & $6.1(U)$ & $0.56(U)$ \\
\hline & $\mathrm{GBPSO}^{\mathrm{c}}$ & $6.8(U)$ & $0.56(U)$ \\
\hline & GBPS222021 & $5.6(U)$ & $0.55(U)$ \\
\hline \multirow{2}{*}{ Well GB-E Mud Pit A } & GBPS240506 ${ }^{b}$ & $2,600(J)$ & $6.2(\mathrm{~J})$ \\
\hline & GBPS241416 & 9.9 (UJ) & $0.59(U)$ \\
\hline \multirow{2}{*}{ Flare stack area } & GBPS250507 & $250(J)$ & 340 \\
\hline & GBPS251012 & $6.5(\mathrm{UJ})$ & $0.58(U)$ \\
\hline \multirow{3}{*}{ Well GB-E Drill Pad } & GBPS260204 & $11(\mathrm{~J})$ & $0.52(U)$ \\
\hline & GBPS261416 & $8.6(\mathrm{UJ})$ & $0.54(U)$ \\
\hline & $\mathrm{GBPSO}^{\mathrm{c}}$ & $5.4(U)$ & $0.54(U)$ \\
\hline \multirow{2}{*}{ Well GB-E Drill Pad } & GBPS270204 & $5.3(U)$ & $0.53(U)$ \\
\hline & GBPS271416 & $5.3(U)$ & $0.53(U)$ \\
\hline \multirow{5}{*}{$\begin{array}{l}\text { Berm that separates } \\
\text { the Well GB-E } \\
\text { Mud Pit A and the } \\
\text { Well GB-2 Mud Pit }\end{array}$} & GBPS280608 & 360 & 3,300 \\
\hline & GBPS281012 & $10(U)$ & $0.57(U)$ \\
\hline & GBPS282224 & $5.6(U)$ & $0.56(U)$ \\
\hline & GBPS283032 & $5.9(U)$ & $0.59(U)$ \\
\hline & GBPS283436 & $6(U)$ & $0.6(U)$ \\
\hline \multirow{2}{*}{ Well GB-1 Mud Pit } & GBPS290103 & $5.5(U)$ & $0.55(U)$ \\
\hline & GBPS291416 & $5.8(U)$ & $0.58(U)$ \\
\hline
\end{tabular}

${ }^{a}$ The Well GB-E Mud Pit D is located within the bounds of the Well GB-2 Mud Pit and appears to overlay the Well GB-2 Mud Pit.

${ }^{b}$ Visual observation of the soil core indicates this sample was collected in a suspect drilling mud layer.

'Sample is field duplicate of above sample.

Darker shaded area $=$ Indicates analytical result exceeds $100 \mathrm{mg} / \mathrm{kg}$

$\mathrm{J}=$ Estimated value

$\mathrm{U}=$ Undetected 


\section{C.5.1.2 Total Volatile Organic Compound Results}

The total VOC analytical results above the minimum reporting limits, along with the associated PALs, are presented in Table C.5-2. Nondetects were not reported to limit the length of the report. 1,2,4-Trimethylbezene was detected in sample GBPS250507 at a concentration of 40,000 micrograms per kilogram ( $\mu \mathrm{g} / \mathrm{kg}$ ) (PAL is 5,700 $\mu \mathrm{g} / \mathrm{kg}$ ). This sample was collected from a depth of 5 to $7 \mathrm{ft}$ bgs from the borehole located at the historic location of the flare stack. This compound is known to be found in many petroleums (Merck, 1976). This sample also contained levels of diesel over $100 \mathrm{mg} / \mathrm{kg}$, and is one of the two samples in which gasoline was detected over $100 \mathrm{mg} / \mathrm{kg}$. The source of the contamination is not known but believed to be associated with production and flaring of natural petroleum hydrocarbons. The contamination is believed to be localized to this location. Further investigation will be conducted in the flare stack area to determine the nature and extent of this potential contamination. No other VOCs were detected at levels which exceeded PALs.

Other VOCs that were detected are either in samples in which TPH was detected above $100 \mathrm{mg} / \mathrm{kg}$ or are common laboratory contaminants (i.e., acetone and methylene chloride). The nonlaboratory contaminants are likely present as part of the TPH formulation. The only exceptions to this are contaminants (i.e., 1,2,4-trimethylbenzene; carbon tetrachloride, and chloroform) detected at concentrations less than 1 percent of the associated PAL, in samples collected from borehole GBP28.

\section{C.5.1.3 Total Semivolatile Organic Compound Results}

The total SVOC analytical results above the minimum reporting limits, along with the associated PALs, are presented in Table C.5-3. Nondetects were not reported to limit length of report. Concentrations of TPH above $100 \mathrm{mg} / \mathrm{kg}$ were detected in seven of the eight samples in which SVOCs were detected. These SVOCs are likely present as part of the TPH formulation. The one sample in which SVOCs were detected but TPH was not detected above $100 \mathrm{mg} / \mathrm{kg}$ was sample GBPS270204. The only SVOC detected above minimum reporting limits in this sample was Bis(2-ethylhexyl) phthalate, which is a common laboratory contaminant. No SVOCs were detected at levels which exceeded PALs. 
Table C.5-2

Soil Sample Results for VOCs (Detects Only)

(Page 1 of 4)

\begin{tabular}{|c|c|c|c|c|c|c|c|c|c|c|c|c|c|c|c|c|c|}
\hline \multirow[b]{2}{*}{ Sample No. } & \multicolumn{17}{|c|}{ Contaminants of Potential Concern $(\mu \mathrm{g} / \mathrm{kg})$} \\
\hline & 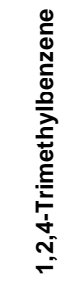 & 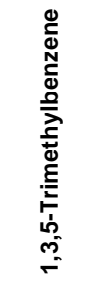 & 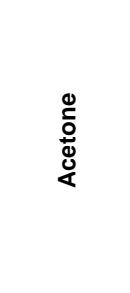 & 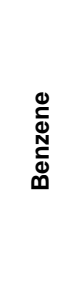 & 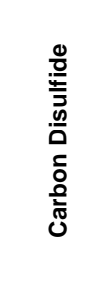 & 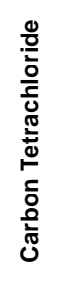 & $\begin{array}{l}E \\
\frac{E}{0} \\
\frac{0}{0} \\
\frac{1}{\delta}\end{array}$ & 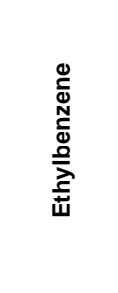 & 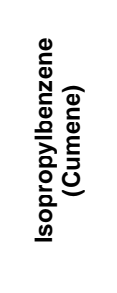 & 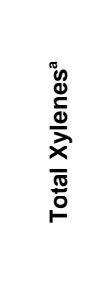 & 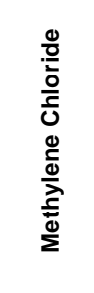 & 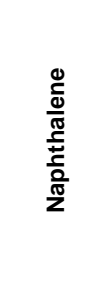 & 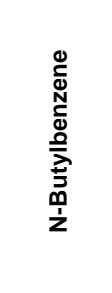 & 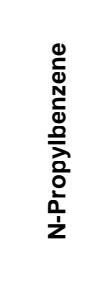 & 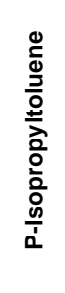 & 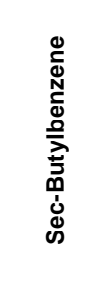 & 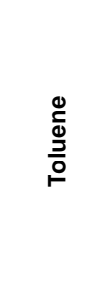 \\
\hline $\begin{array}{c}\text { Preliminary } \\
\text { Action } \\
\text { Levels }^{\mathbf{b}}\end{array}$ & 5,700 & 70,000 & $6,200,000$ & 1,500 & 720,000 & 530 & 520 & 230,000 & 520,000 & 210,000 & 21,000 & 190,000 & 240,000 & 240,000 & NA & 220,000 & 520,000 \\
\hline GBPS010609 & 780 & 220 & -- & $\begin{array}{l}5.3 \\
(\mathrm{~J})\end{array}$ & -- & -- & -- & $14(\mathrm{~J})$ & $15(J)$ & 200 & -- & 1,200 & $57(\mathrm{~J})$ & $35(J)$ & 160 & $39(\mathrm{~J})$ & -- \\
\hline GBPS010911 & 260 & 72 & -- & -- & -- & -- & -- & $4.1(\mathrm{~J})$ & $5.1(\mathrm{~J})$ & 60 & -- & 260 & $16(J)$ & 13 & 31 & 13 & -- \\
\hline GBPS020610 & 44 & 78 & -- & -- & -- & -- & -- & -- & -- & -- & -- & 280 & -- & $3.6(\mathrm{~J})$ & 34 & $6.8(\mathrm{~J})$ & -- \\
\hline GBPS021719 & -- & -- & 24 & -- & -- & -- & -- & -- & -- & -- & -- & -- & -- & -- & -- & -- & -- \\
\hline GBPS030406 & -- & -- & -- & -- & -- & -- & -- & -- & -- & -- & -- & $4.4(\mathrm{~J})$ & -- & -- & -- & -- & -- \\
\hline GBPS031416 & -- & -- & $19(\mathrm{~J})$ & -- & -- & -- & -- & -- & -- & -- & -- & -- & -- & -- & -- & -- & -- \\
\hline GBPS031416 & -- & -- & 65 & -- & -- & -- & -- & -- & -- & -- & -- & -- & -- & -- & -- & -- & -- \\
\hline GBPS040406 & -- & -- & 26 & -- & -- & -- & -- & -- & -- & -- & -- & -- & -- & -- & -- & -- & -- \\
\hline GBPS040911 & -- & -- & 73 & -- & -- & -- & -- & -- & -- & -- & -- & -- & -- & -- & -- & -- & -- \\
\hline GBPS041416 & -- & -- & 180 & -- & -- & -- & -- & -- & -- & -- & -- & -- & -- & -- & -- & -- & -- \\
\hline GBPS050408 & -- & -- & 190 & -- & -- & -- & -- & -- & -- & -- & -- & -- & -- & -- & -- & -- & -- \\
\hline GBPS051012 & -- & -- & 46 & -- & -- & -- & -- & -- & -- & -- & -- & -- & -- & -- & -- & -- & -- \\
\hline GBPS $01^{\circ}$ & -- & -- & 31 & -- & -- & -- & -- & -- & -- & -- & -- & -- & -- & -- & -- & -- & -- \\
\hline GBPS061618 & -- & -- & 160 & -- & -- & -- & -- & -- & -- & -- & -- & -- & -- & -- & -- & -- & -- \\
\hline GBPS071012 & -- & -- & 110 & -- & -- & -- & -- & -- & -- & -- & -- & -- & -- & -- & -- & -- & -- \\
\hline
\end{tabular}


Table C.5-2

Soil Sample Results for VOCs (Detects Only)

(Page 2 of 4)

\begin{tabular}{|c|c|c|c|c|c|c|c|c|c|c|c|c|c|c|c|c|c|}
\hline \multirow[b]{2}{*}{ Sample No. } & \multicolumn{17}{|c|}{ Contaminants of Potential Concern $(\mu \mathrm{g} / \mathrm{kg})$} \\
\hline & 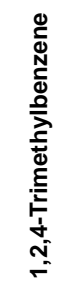 & 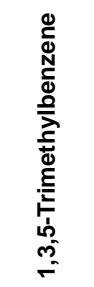 & 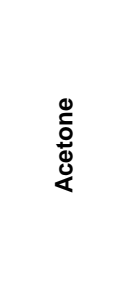 & 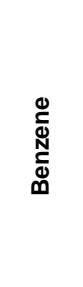 & 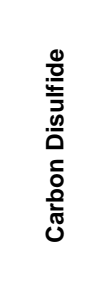 & 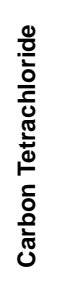 & 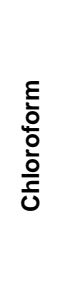 & 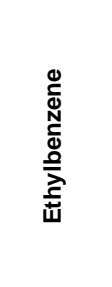 & 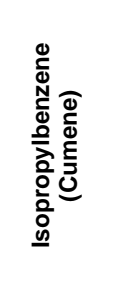 & 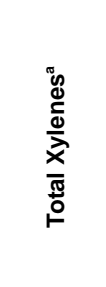 & 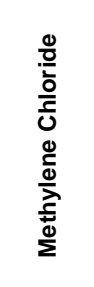 & 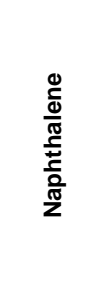 & 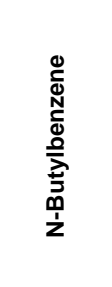 & 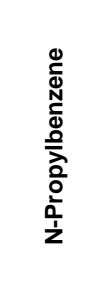 & 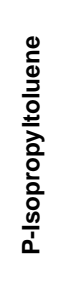 & 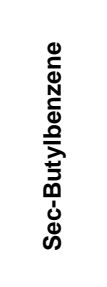 & 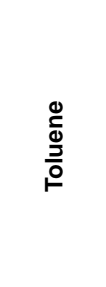 \\
\hline $\begin{array}{l}\text { Preliminary } \\
\text { Action } \\
\text { Levels }^{\mathrm{b}}\end{array}$ & 5,700 & 70,000 & $6,200,000$ & 1,500 & 720,000 & 530 & 520 & 230,000 & 520,000 & 210,000 & 21,000 & 190,000 & 240,000 & 240,000 & NA & 220,000 & 520,000 \\
\hline GBPS071618 & -- & -- & 97 & -- & -- & -- & -- & -- & -- & -- & $\begin{array}{l}110 \\
\text { (B) }\end{array}$ & -- & -- & -- & -- & -- & -- \\
\hline GBPS080204 & -- & -- & -- & -- & -- & -- & -- & -- & -- & -- & $88(\mathrm{~B})$ & -- & -- & -- & -- & -- & -- \\
\hline GBPS081416 & -- & -- & $130(B)$ & -- & -- & -- & -- & -- & -- & -- & -- & -- & -- & -- & -- & -- & -- \\
\hline GBPS101416 & -- & -- & 85 & -- & -- & -- & -- & -- & -- & -- & $54(\mathrm{~B})$ & -- & -- & -- & -- & -- & -- \\
\hline GBPS111416 & -- & -- & -- & -- & -- & -- & -- & -- & -- & -- & $66(\mathrm{~B})$ & -- & -- & -- & -- & -- & -- \\
\hline GBPS120204 & -- & -- & 99 & -- & -- & -- & -- & -- & -- & -- & -- & -- & -- & -- & -- & -- & -- \\
\hline GBPS121719 & -- & -- & 190 & -- & -- & -- & -- & -- & -- & -- & $70(\mathrm{~B})$ & -- & -- & -- & -- & -- & -- \\
\hline GBPS131920 & -- & -- & 150 & -- & -- & -- & -- & -- & -- & -- & -- & -- & -- & -- & -- & -- & -- \\
\hline GBPS150204 & -- & -- & 130 & -- & -- & -- & -- & -- & -- & -- & -- & -- & -- & -- & -- & -- & -- \\
\hline GBPS151416 & -- & -- & 170 & -- & -- & -- & -- & -- & -- & -- & -- & -- & -- & -- & -- & -- & -- \\
\hline GBPS160204 & -- & -- & 52 & -- & -- & -- & -- & -- & -- & -- & -- & -- & -- & -- & -- & -- & -- \\
\hline GBPS 161416 & -- & -- & 30 & -- & -- & -- & -- & -- & -- & -- & -- & -- & -- & -- & -- & -- & -- \\
\hline GBPS170204 & -- & -- & $14(\mathrm{~J})$ & -- & -- & -- & -- & -- & -- & -- & -- & -- & -- & -- & -- & -- & -- \\
\hline $\begin{array}{c}\text { GBPS171314 } \\
\text { RR1 }\end{array}$ & -- & -- & 1,600 & -- & -- & -- & -- & -- & -- & -- & -- & -- & -- & -- & -- & -- & -- \\
\hline
\end{tabular}


Table C.5-2

Soil Sample Results for VOCs (Detects Only)

(Page 3 of 4)

\begin{tabular}{|c|c|c|c|c|c|c|c|c|c|c|c|c|c|c|c|c|c|}
\hline \multirow[b]{2}{*}{ Sample No. } & \multicolumn{17}{|c|}{ Contaminants of Potential Concern $(\mu \mathrm{g} / \mathrm{kg})$} \\
\hline & 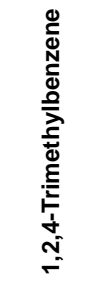 & 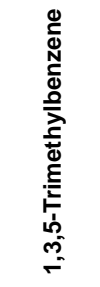 & 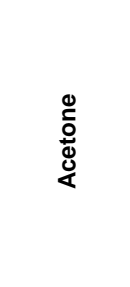 & 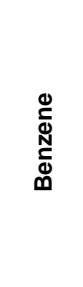 & 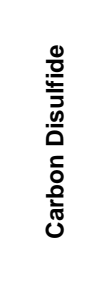 & 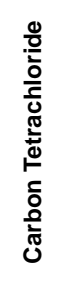 & $\begin{array}{l}\varepsilon \\
\frac{E}{0} \\
\frac{0}{0} \\
\frac{0}{\bar{c}} \\
\end{array}$ & 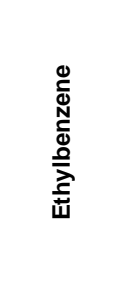 & 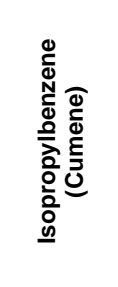 & 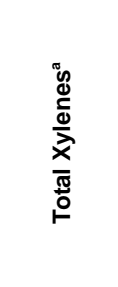 & 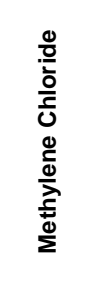 & 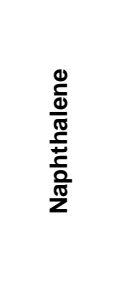 & 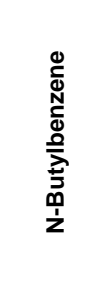 & 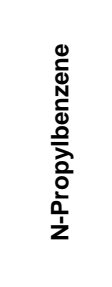 & 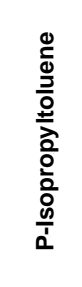 & 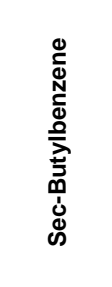 & 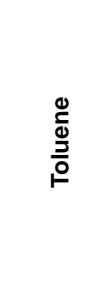 \\
\hline $\begin{array}{c}\text { Preliminary } \\
\text { Action } \\
\text { Levels }^{\mathbf{b}}\end{array}$ & 5,700 & 70,000 & $6,200,000$ & 1,500 & 720,000 & 530 & 520 & 230,000 & 520,000 & 210,000 & 21,000 & 190,000 & 240,000 & 240,000 & NA & 220,000 & 520,000 \\
\hline GBPS172123 & -- & -- & $21(\mathrm{~J})$ & -- & -- & -- & -- & -- & -- & -- & -- & -- & -- & -- & -- & -- & -- \\
\hline GBPS180911 & -- & -- & $55(J)$ & -- & -- & -- & -- & -- & -- & -- & $2.6(\mathrm{~J})$ & -- & -- & -- & -- & -- & -- \\
\hline GBPS181416 & -- & -- & $16(\mathrm{~J})$ & -- & -- & -- & -- & -- & -- & -- & -- & -- & -- & -- & -- & -- & -- \\
\hline GBPS182122 & -- & -- & $17(\mathrm{~J})$ & -- & -- & -- & -- & -- & -- & -- & -- & -- & -- & -- & -- & -- & -- \\
\hline GBPS201416 & -- & -- & 24 & & -- & -- & -- & -- & -- & -- & -- & -- & -- & -- & -- & -- & -- \\
\hline GBPS210204 & -- & -- & 220 & -- & -- & -- & -- & -- & -- & -- & -- & -- & -- & -- & -- & -- & -- \\
\hline GBPS211416 & -- & -- & 450 & -- & -- & -- & -- & -- & -- & -- & -- & -- & -- & -- & -- & -- & -- \\
\hline GBPS03 & -- & -- & $15(\mathrm{~J})$ & -- & -- & -- & -- & -- & -- & -- & -- & -- & -- & -- & -- & -- & -- \\
\hline GBPS222021 & -- & -- & $13(\mathrm{~J})$ & -- & -- & -- & -- & -- & -- & -- & -- & -- & -- & -- & -- & -- & -- \\
\hline GBPS240506 & $650(\mathrm{~J})$ & $220(\mathrm{~J})$ & $80(J)$ & $12(\mathrm{~J})$ & $1.3(\mathrm{~J})$ & -- & -- & $160(\mathrm{~J})$ & $68(\mathrm{~J})$ & 810 & -- & $730(\mathrm{~J})$ & $35(\mathrm{~J})$ & $120(\mathrm{~J})$ & $32(\mathrm{~J})$ & $36(\mathrm{~J})$ & $55(\mathrm{~J})$ \\
\hline GBPS241416 & -- & -- & 100 & -- & -- & -- & -- & -- & -- & -- & $62(\mathrm{~J})$ & -- & -- & -- & -- & -- & -- \\
\hline GBPS250507 & $\begin{array}{c}40,000 \\
\text { (J) }\end{array}$ & $\begin{array}{c}24,000 \\
(\mathrm{~J})\end{array}$ & -- & $23(\mathrm{~J})$ & -- & $\begin{array}{l}6.3 \\
(\mathrm{~J})\end{array}$ & -- & $1,900(\mathrm{~J})$ & $6,600(\mathrm{~J})$ & 38,000 & -- & $3,300(\mathrm{~J})$ & $\begin{array}{c}8,100 \\
(\mathrm{~J})\end{array}$ & $\begin{array}{c}6,700 \\
(J)\end{array}$ & $\begin{array}{c}8,500 \\
(\mathrm{~J})\end{array}$ & $4,800(\mathrm{~J})$ & $\begin{array}{c}2,400 \\
(\mathrm{~J})\end{array}$ \\
\hline GBPS260204 & -- & -- & 440 & -- & -- & -- & -- & -- & -- & -- & -- & -- & -- & -- & -- & -- & -- \\
\hline GBPS251012 & -- & -- & -- & -- & -- & -- & -- & -- & -- & -- & $44(\mathrm{~J})$ & -- & -- & -- & -- & -- & -- \\
\hline GBPS261416 & -- & -- & 73 & -- & -- & -- & -- & -- & -- & -- & -- & -- & -- & -- & -- & -- & -- \\
\hline
\end{tabular}


Table C.5-2

Soil Sample Results for VOCs (Detects Only)

(Page 4 of 4 )

\begin{tabular}{|c|c|c|c|c|c|c|c|c|c|c|c|c|c|c|c|c|c|}
\hline \multirow[b]{2}{*}{ Sample No. } & \multicolumn{17}{|c|}{ Contaminants of Potential Concern $(\mu \mathrm{g} / \mathrm{kg})$} \\
\hline & 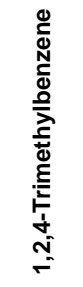 & 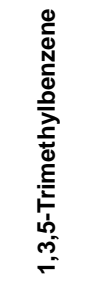 & 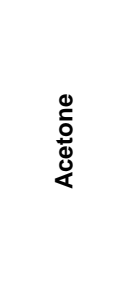 & 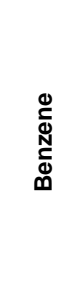 & 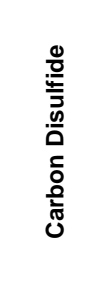 & 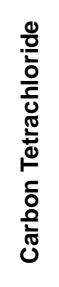 & $\begin{array}{l}\varepsilon \\
\frac{E}{0} \\
\frac{0}{0} \\
\frac{0}{\bar{\tau}} \\
\end{array}$ & 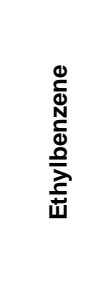 & 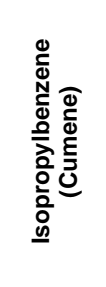 & 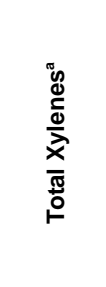 & 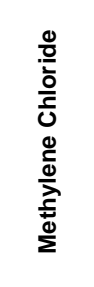 & 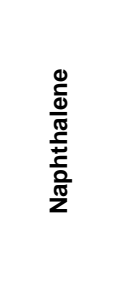 & 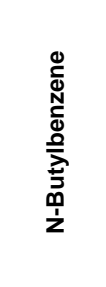 & 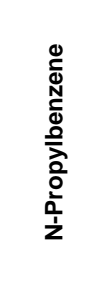 & 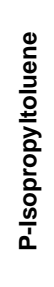 & 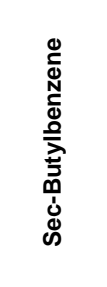 & 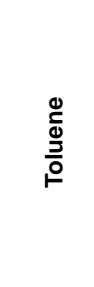 \\
\hline $\begin{array}{l}\text { Preliminary } \\
\text { Action } \\
\text { Levels }^{\mathbf{b}}\end{array}$ & 5,700 & 70,000 & $6,200,000$ & 1,500 & 720,000 & 530 & 520 & 230,000 & 520,000 & 210,000 & 21,000 & 190,000 & 240,000 & 240,000 & NA & 220,000 & 520,000 \\
\hline GBPS280608 & 520 & 210 & 980 & -- & -- & -- & -- & 72 & 36 & 920 & $31(\mathrm{~J})$ & 130 & 37 & 75 & 29 & -- & 150 \\
\hline GBPS281012 & $3.4(\mathrm{~J})$ & -- & -- & -- & -- & -- & -- & -- & -- & -- & -- & 11 & -- & -- & -- & -- & -- \\
\hline GBPS282224 & -- & -- & 49 & -- & -- & -- & -- & -- & -- & -- & -- & -- & -- & -- & -- & -- & -- \\
\hline GBPS283032 & -- & -- & $18(\mathrm{~J})$ & -- & -- & $\begin{array}{l}1.7 \\
\text { (J) }\end{array}$ & -- & -- & -- & -- & -- & -- & -- & -- & -- & -- & -- \\
\hline GBPS283436 & -- & -- & -- & -- & -- & -- & $\begin{array}{l}1.1 \\
(\mathrm{~J})\end{array}$ & -- & -- & -- & -- & -- & -- & -- & -- & -- & -- \\
\hline GBPS291416 & -- & -- & 160 & -- & -- & -- & -- & -- & -- & -- & -- & -- & -- & -- & -- & -- & -- \\
\hline
\end{tabular}

${ }^{a} X y l e n e$ results were reported as concentrations of $m+p$-xylene and o-xylene. The reported values were added to get total xylene.

${ }^{b}$ Environmental Protection Agency Region IX Industrial Preliminary Remediation Goals (EPA, 1999a).

'Sample GBPS01 is a field duplicate of GBPS051820. There were no VOC detects for GBPS051820.

dSample is field duplicate of above sample.

$--=$ Analyte not detected above minimum reporting limits.

$\mathrm{J}=$ Estimated value

$\mathrm{B}=$ Analyte found in associated blank

Darker shaded area $=$ Indicates analytical result exceeds PAL 
Table C.5-3

Soil Sample Results for SVOC (Detects Only)

\begin{tabular}{|c|c|c|c|c|c|}
\hline \multirow[b]{2}{*}{ Sample No. } & \multicolumn{5}{|c|}{ Contaminants of Potential Concern $(\mu \mathrm{g} / \mathrm{kg})$} \\
\hline & 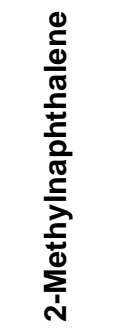 & $\begin{array}{l}\stackrel{0}{\frac{\pi}{J}} \\
\frac{0}{0} \\
\frac{\partial}{4}\end{array}$ & 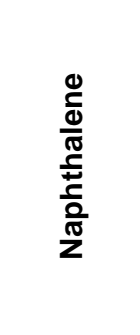 & 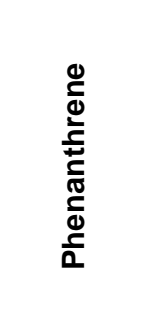 & 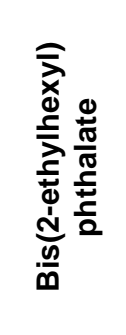 \\
\hline $\begin{array}{c}\text { Preliminary Action } \\
\text { Levels }^{\mathrm{a}}\end{array}$ & NA & $33,000,000$ & 190,000 & NA & 180,000 \\
\hline GBPS010609 & 3,100 & 570 & 1,000 & 660 & -- \\
\hline GBPS010911 & 610 & -- & $190(J)$ & -- & -- \\
\hline GBPS020610 & 1,400 & -- & -- & $200(J)$ & -- \\
\hline GBPS030406 & 1,400 & -- & 440 & 490 & -- \\
\hline GBPS240506 & 15,000 & $990(\mathrm{~J})$ & 6,600 & $1,300(J)$ & -- \\
\hline GBPS250507 & 1,100 & -- & 440 & -- & -- \\
\hline GBPS270204 & -- & -- & -- & -- & 67 \\
\hline GBPS280608 & 310 & -- & -- & -- & 92 \\
\hline
\end{tabular}

aEnvironmental Protection Agency Region IX Industrial Preliminary Remediation Goals (EPA, 1999a)

NA = Not applicable (There is no Region IX Industrial Preliminary Remediation Goals for this constituent.)

-- = Analyte not detected above minimum reporting limits.

$\mathrm{J}=$ Estimated value

\section{C.5.1.4 Total RCRA Metals}

The total RCRA metals analytical results, along with the associated PALs, are presented in

Table C.5-4. Background sample results are located at the bottom of the table. Only arsenic was found in concentrations which exceeded the PAL. Statistical comparison of the arsenic results for the background samples and site characterization samples indicate the two sets of results are not "significantly different." 
Table C.5-4

Soil Sample Results for RCRA Metals

(Page 1 of 4)

\begin{tabular}{|c|c|c|c|c|c|c|c|c|}
\hline \multirow[b]{2}{*}{ Sample Number } & \multicolumn{8}{|c|}{ Contaminants of Potential Concern $(\mathrm{mg} / \mathrm{kg})$} \\
\hline & 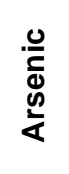 & 云 & 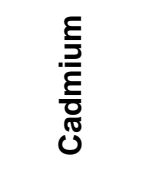 & 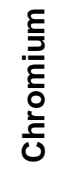 & ర్త్ర & $\begin{array}{l}\frac{\lambda}{J} \\
0 \\
\frac{0}{d} \\
\Sigma\end{array}$ & 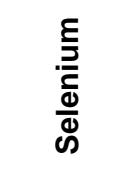 & 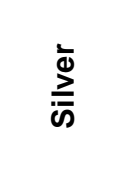 \\
\hline $\begin{array}{l}\text { Preliminary } \\
\text { Action Level }^{\mathrm{a}}\end{array}$ & 2.7 & 100,000 & 810 & 450 & 1,000 & 610 & 10,000 & 10,000 \\
\hline GBPS010609 & 7 & 270 & $1.2(\mathrm{U})$ & 15 & 15 & 0.009 (UJ) & $1.2(U)$ & $1.2(U)$ \\
\hline GBPS010911 & 1.7 & 260 & $0.59(U)$ & 9.7 & 62 & 0.015 (UJ) & $0.59(U)$ & $1.2(U)$ \\
\hline GBPS011214 & 2.1 & 320 & $1.2(U J)$ & 17 & 14 & 0.02 (UJ) & $1.1(\mathrm{~B})$ & $1.2(U)$ \\
\hline GBPS011921 & 1.4 & 88 & 0.57 (UJ) & 11 & 12 & $0.081(\mathrm{~B})$ & $0.42(\mathrm{~B})$ & $1.1(\mathrm{U})$ \\
\hline GBPS020610 & 2.7 & 190 & $0.57(U)$ & 13 & 27 & 0.017 (UJ) & $0.55(\mathrm{~B})$ & $1.1(\mathrm{U})$ \\
\hline GBPS021719 & 1.5 & 380 & $0.59(\mathrm{U})$ & 9.9 & 11 & 0.088 (UJ) & $0.59(\mathrm{U})$ & 1.2 (UJ) \\
\hline GBPS030406 & 2.2 & 190 & $0.58(U)$ & 22 & 9.9 & 0.012 (UJ) & $0.53(\mathrm{~B})$ & $1.2(\mathrm{U})$ \\
\hline GBPS030911 & 3 & 220 & $0.56(\mathrm{U})$ & 13 & 7.7 & 0.112 (UJ) & $0.48(\mathrm{~B})$ & 1.1 (UJ) \\
\hline GBPS031416 & 3 & 220 & $0.56(U)$ & 12 & 7.6 & 0.113 (UJ) & $0.56(\mathrm{U})$ & 1.1 (UJ) \\
\hline GBPS040406 & 3.1 & 220 & $0.57(U)$ & 14 & 7.4 & 0.011 (UJ) & $0.53(\mathrm{~B})$ & $1.1(\mathrm{U})$ \\
\hline GBPS040911 & 2.9 & 200 & $0.55(\mathrm{U})$ & 10 & 6.2 & 0.109 (UJ) & $0.55(\mathrm{U})$ & 1.1 (UJ) \\
\hline GBPS041416 & 3.1 & 230 & $0.56(U)$ & 13 & 8.2 & 0.113 (UJ) & $0.56(U)$ & 1.1 (UJ) \\
\hline GBPS050408 & 3.3 & 220 & $0.58(U)$ & 15 & 8.5 & 0.011 (UJ) & $0.39(\mathrm{~B})$ & $1.2(\mathrm{U})$ \\
\hline GBPS051012 & 2.7 & 160 & $0.53(\mathrm{U})$ & 8.8 & 5.8 & 0.106 (UJ) & $0.53(\mathrm{U})$ & 1.1 (UJ) \\
\hline GBPS051820 & 2.5 & 150 & $0.55(\mathrm{U})$ & 9.4 & 6.4 & 0.11 (UJ) & $0.55(\mathrm{U})$ & 1.1 (UJ) \\
\hline GBPS01 ${ }^{b}$ & 2.9 & 190 & $0.55(\mathrm{U})$ & 10 & 7 & 0.11 (UJ) & $0.55(\mathrm{U})$ & 1.1 (UJ) \\
\hline GBPS060608 & 2.9 & 130 & $0.52(U)$ & 26 & 6.5 & 0.012 (UJ) & $0.52(\mathrm{U})$ & $1(U)$ \\
\hline GBPS061012 & 2.2 & 140 & $0.53(U)$ & 11 & 5.4 & $0.005(U)$ & 0.57 & $1.1(\mathrm{U})$ \\
\hline GBPS061618 & 2 & 340 & $0.58(U)$ & 13 & 10 & $0.12(\mathrm{U})$ & $0.4(\mathrm{~B})$ & $1.2(U)$ \\
\hline GBPS070608 & 2.7 & 310 & $0.57(\mathrm{U})$ & 12 & 14 & 0.006 (UJ) & $0.41(\mathrm{~B})$ & $1.1(\mathrm{U})$ \\
\hline GBPS071012 & 2.4 & 190 & $0.57(U)$ & 10 & 6.8 & $0.005(U)$ & $0.32(\mathrm{~B})$ & $1.1(\mathrm{U})$ \\
\hline GBPS071618 & 2.3 & 290 & $0.56(U)$ & 10 & 6.1 & $0.003(U)$ & $0.56(U)$ & $1.1(\mathrm{U})$ \\
\hline GBPS080204 & 1.8 & 120 & $0.52(U)$ & 8.2 & 6 & $0.1(\mathrm{U})$ & $0.52(\mathrm{U})$ & $1(\mathrm{U})$ \\
\hline GBPS081416 & 2.3 & 150 & $0.55(\mathrm{U})$ & 8.8 & 6.1 & $0.11(\mathrm{U})$ & $0.55(\mathrm{U})$ & $1.1(\mathrm{U})$ \\
\hline
\end{tabular}


Table C.5-4

Soil Sample Results for RCRA Metals

(Page 2 of 4)

\begin{tabular}{|c|c|c|c|c|c|c|c|c|}
\hline \multirow[b]{2}{*}{ Sample Number } & \multicolumn{8}{|c|}{ Contaminants of Potential Concern $(\mathrm{mg} / \mathrm{kg})$} \\
\hline & 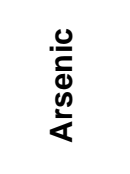 & 云 & 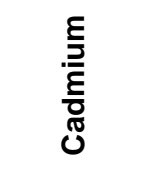 & 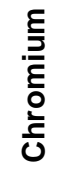 & ర్ల్ర & $\begin{array}{l}\frac{\lambda}{J} \\
0 \\
\frac{0}{d} \\
\Sigma\end{array}$ & 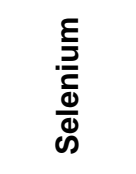 & 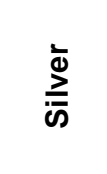 \\
\hline $\begin{array}{l}\text { Preliminary } \\
\text { Action Level }^{\mathrm{a}}\end{array}$ & 2.7 & 100,000 & 810 & 450 & 1,000 & 610 & 10,000 & 10,000 \\
\hline GBPS090204 & 2.8 & 210 & $0.54(\mathrm{U})$ & 13 & 8.3 & $0.007(U)$ & $0.49(\mathrm{~B})$ & $1.1(U)$ \\
\hline GBPS091416 & 2.1 & 140 & $0.53(U)$ & 8.6 & 6.9 & $0.11(\mathrm{U})$ & $0.53(U)$ & $1.1(U)$ \\
\hline GBPS100204 & 3.3 & 230 & $0.56(U)$ & 16 & 11 & 0.023 (UJ) & 0.75 & $1.1(U)$ \\
\hline GBPS101416 & 3.5 & 240 & $0.57(U)$ & 12 & 9.5 & $0.11(\mathrm{U})$ & $0.57(U)$ & $1.1(U)$ \\
\hline GBPS110204 & 3.1 & 240 & $0.55(\mathrm{U})$ & 13 & 7.3 & 0.007 (UJ) & $0.43(\mathrm{~B})$ & $1.1(U)$ \\
\hline GBPS111416 & 3.3 & 240 & $0.57(\mathrm{U})$ & 11 & 9 & $0.005(U)$ & $0.57(\mathrm{U})$ & $1.1(U)$ \\
\hline GBPS120204 & 1.9 & 430 & $0.033(\mathrm{U})$ & 15 & 17 & $0.088(\mathrm{~B})$ & $0.54(\mathrm{~B})$ & $1.1(U)$ \\
\hline GBPS120608 & 2.4 & 2,300 & $0.54(\mathrm{U})$ & 12 & 31 & $0.012(U)$ & 0.42 (B) & $1.1(U)$ \\
\hline GBPS121719 & 2.2 & 180 & $0.58(U)$ & 12 & 9.6 & $0.12(\mathrm{U})$ & $0.58(\mathrm{U})$ & $1.2(U)$ \\
\hline GBPS131920 & 3 & 150 & 0.56 (UJ) & 10 & 6.9 & 0.11 (UJ) & 0.47 (B) & $1.1(U)$ \\
\hline GBPS150204 & 2.3 & 160 & 0.52 (UJ) & 11 & 6.3 & 0.1 (UJ) & 0.58 & $1(\mathrm{U})$ \\
\hline GBPS151416 & 2.4 & 210 & 0.58 (UJ) & 13 & 8.4 & 0.12 (UJ) & 0.86 & $1.2(\mathrm{U})$ \\
\hline GBPS160204 & 2.6 & 180 & 0.52 (UJ) & 13 & 7.2 & 0.002 (UJ) & 0.72 & $1(U)$ \\
\hline $\mathrm{GBPS} 2^{\mathrm{b}}$ & 2.7 & 190 & $0.52(U)$ & 13 & 7.7 & 0.004 (UJ) & 0.72 & $1(U)$ \\
\hline GBPS161416 & 1.8 & 160 & 0.58 (UJ) & 12 & 7.4 & 0.12 (UJ) & $0.58(\mathrm{U})$ & $1.2(U)$ \\
\hline GBPS170204 & 2.5 & 170 & $0.53(U)$ & 12 & 8.1 & 0.005 (UJ) & 0.54 & $1.1(U)$ \\
\hline GBPS171314 & 2.8 & 160 & 0.54 (UJ) & 10 & 6.5 & 0.11 (UJ) & $0.37(\mathrm{~B})$ & $1.1(U)$ \\
\hline GBPS172123 & $0.62(\mathrm{~B})$ & 110 & 0.56 (UJ) & 11 & 5 & 0.11 (UJ) & $0.56(U)$ & $1.1(U)$ \\
\hline GBPS180608 & 2.7 & 210 & 0.55 (UJ) & 14 & 14 & 0.005 (UJ) & 0.67 & $1.1(U)$ \\
\hline GBPS180911 & 2.9 & 230 & $0.68(\mathrm{U})$ & 13 & 63 & 0.012 (UJ) & $0.45(\mathrm{~B})$ & $1.4(U)$ \\
\hline GBPS181416 & 3 & 160 & 0.54 (UJ) & 11 & 6.8 & 0.11 (UJ) & $0.54(U)$ & $1.1(U)$ \\
\hline GBPS182122 & 2.7 & 580 & 1.2 (UJ) & 16 & 12 & 0.082 (UJ) & $1.2(\mathrm{U})$ & $1.2(U)$ \\
\hline GBPS190204 & 3.3 & 290 & 1.1 (UJ) & 14 & 13 & 0.014 (UJ) & $1.1(\mathrm{U})$ & $1.1(\mathrm{U})$ \\
\hline GBPS191416 & 2.6 & 140 & $0.53(\mathrm{U})$ & 8.1 & 4.5 & 0.11 (UJ) & 0.71 & $1.1(U)$ \\
\hline
\end{tabular}


Table C.5-4

Soil Sample Results for RCRA Metals

(Page 3 of 4)

\begin{tabular}{|c|c|c|c|c|c|c|c|c|}
\hline \multirow[b]{2}{*}{ Sample Number } & \multicolumn{8}{|c|}{ Contaminants of Potential Concern $(\mathrm{mg} / \mathrm{kg})$} \\
\hline & 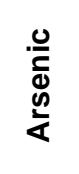 & 占 & $\begin{array}{l}\frac{E}{J} \\
\frac{\bar{g}}{0} \\
\stackrel{\mathbb{J}}{0}\end{array}$ & 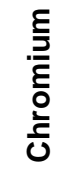 & ర్ల & 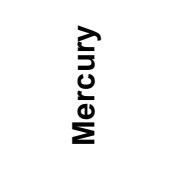 & $\frac{\Xi}{3}$ & 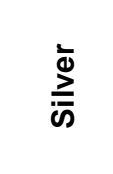 \\
\hline $\begin{array}{l}\text { Preliminary } \\
\text { Action Level }^{\mathrm{a}}\end{array}$ & 2.7 & 100,000 & 810 & 450 & 1,000 & 610 & 10,000 & 10,000 \\
\hline GBPS200204 & 2.3 & 290 & 1.1 & 12 & 26 & 0.021 (UJ) & $0.43(\mathrm{~B})$ & $1.1(U)$ \\
\hline GBPS201416 & 2.7 & 170 & 0.56 (UJ) & 10 & 6.2 & 0.11 (UJ) & 0.59 & $1.1(U)$ \\
\hline GBPS210204 & 1.8 & 380 & $0.37(\mathrm{~B})$ & 11 & 12 & $0.052(\mathrm{~B})$ & $0.34(\mathrm{~B})$ & $1.1(U)$ \\
\hline GBPS210608 & 2.7 & 170 & $0.53(\mathrm{U})$ & 9.5 & 5.6 & 0.11 (UJ) & 0.54 & $1.1(\mathrm{U})$ \\
\hline GBPS211416 & 2.7 & 220 & $0.58(U)$ & 13 & 8.1 & 0.12 (UJ) & 0.68 & $1.2(\mathrm{U})$ \\
\hline GBPS220204 & 2.5 & 1,500 & $1.1(\mathrm{U})$ & 20 & 13 & 0.029 (UJ) & $1.1(\mathrm{U})$ & $1.1(U)$ \\
\hline GBPS221416 & 1.6 & 180 & $1.1(\mathrm{U})$ & 20 & 12 & 0.028 (UJ) & $1.1(\mathrm{U})$ & $1.1(\mathrm{U})$ \\
\hline $\mathrm{GBPSO}^{\mathrm{b}}$ & 1.6 & 150 & $1.1(\mathrm{U})$ & 19 & 12 & $0.028(\mathrm{UJ})$ & $1.1(\mathrm{U})$ & $1.1(\mathrm{U})$ \\
\hline GBPS222021 & 1.1 & 330 & $0.071(\mathrm{~B})$ & 15 & 6.5 & 0.11 (UJ) & 0.76 & $1.1(U)$ \\
\hline GBPS240506 & 3 & 210 & 0.6 (UJ) & 30 & $19(\mathrm{~J})$ & 0.01 (UJ) & 1.1 & $1.2(U)$ \\
\hline GBPS241416 & 3.8 & 280 & 0.59 (UJ) & 17 & $10(\mathrm{~J})$ & 0.002 (UJ) & 1.3 & $1.2(U)$ \\
\hline GBPS250507 & 2.7 & 230 & 0.56 (UJ) & 39 & $13(\mathrm{~J})$ & 0.11 (UJ) & 0.85 & $1.1(U)$ \\
\hline GBPS251012 & 3.5 & 370 & 0.58 (UJ) & 16 & $10(\mathrm{~J})$ & 0.12 (UJ) & 1 & $1.2(U)$ \\
\hline GBPS260204 & 2.1 & 120 & $0.52(U)$ & 8.3 & 5 & 0.1 (UJ) & $0.52(U)$ & $1(U)$ \\
\hline GBPS261416 & 2.5 & 140 & $0.54(U)$ & 8.7 & 6.3 & 0.11 (UJ) & $0.54(U)$ & $1.1(\mathrm{U})$ \\
\hline $\mathrm{GBPSO}^{\mathrm{b}}$ & 3.2 & 200 & $0.54(U)$ & 11 & 7.1 & $0.11(U)$ & $0.54(U)$ & $1.1(U)$ \\
\hline GBPS270204 & 2.4 & 140 & $0.53(\mathrm{U})$ & 10 & 7 & $0.11(\mathrm{U})$ & $0.53(U)$ & $1.1(U)$ \\
\hline GBPS271416 & 2.9 & 190 & $0.53(\mathrm{U})$ & 10 & 6.5 & $0.11(\mathrm{U})$ & $0.3(\mathrm{~B})$ & $1.1(\mathrm{U})$ \\
\hline GBPS280608 & 3 & 330 & $0.57(\mathrm{U})$ & 66 & 17 & $0.11(\mathrm{U})$ & $0.57(\mathrm{U})$ & $1.1(U)$ \\
\hline GBPS281012 & 3.3 & 390 & $0.57(\mathrm{U})$ & 15 & 9 & $0.11(\mathrm{U})$ & $0.57(\mathrm{U})$ & $1.1(U)$ \\
\hline GBPS282224 & 2.3 & 170 & $0.56(U)$ & 9.7 & 6.8 & $0.11(U)$ & $0.56(U)$ & $1.1(U)$ \\
\hline GBPS283032 & 2.6 & 240 & $0.59(U)$ & 12 & 9.3 & $0.12(U)$ & $0.39(\mathrm{~B})$ & $1.2(U)$ \\
\hline GBPS283436 & 2.5 & 280 & $0.6(U)$ & 11 & 9.2 & 0.005 (UJ) & $0.41(\mathrm{~B})$ & $1.2(\mathrm{U})$ \\
\hline GBPS290103 & 2.3 & 410 & $1.1(\mathrm{U})$ & 16 & 12 & 0.018 (UJ) & $1.1(\mathrm{U})$ & $1.1(U)$ \\
\hline
\end{tabular}


Table C.5-4

Soil Sample Results for RCRA Metals

(Page 4 of 4 )

\begin{tabular}{|c|c|c|c|c|c|c|c|c|}
\hline \multirow[b]{2}{*}{ Sample Number } & \multicolumn{8}{|c|}{ Contaminants of Potential Concern $(\mathrm{mg} / \mathrm{kg})$} \\
\hline & 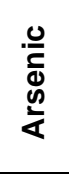 & $\frac{\Sigma}{\frac{\varepsilon}{D}}$ & 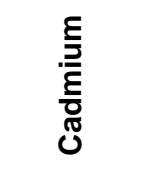 & $\begin{array}{l}\text { E } \\
\text { 를 } \\
\frac{0}{0} \\
\frac{c}{0}\end{array}$ & ర్త్ర & 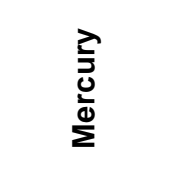 & $\frac{E}{\supset}$ & $\frac{\grave{D}}{\bar{c}}$ \\
\hline $\begin{array}{l}\text { Preliminary } \\
\text { Action Level }^{\mathrm{a}}\end{array}$ & 2.7 & 100,000 & 810 & 450 & 1,000 & 610 & 10,000 & 10,000 \\
\hline GBPS291416 & 1.6 & 320 & $0.58(U)$ & 14 & 8.1 & $0.12(U)$ & $0.58(U)$ & $1.2(U)$ \\
\hline GBPB010204 & 1.8 & 310 & $0.53(U)$ & 11 & 5.6 & 0.11 (UJ) & $0.53(U)$ & $1.1(U)$ \\
\hline GBPB010912 & 1.6 & 250 & $1.1(\mathrm{U})$ & 15 & 7.2 & $0.008(\mathrm{UJ})$ & $1.1(\mathrm{U})$ & $1.1(U)$ \\
\hline GBPB030407 & 3.2 & 280 & $0.54(U)$ & 13 & 8.5 & 0.11 (UJ) & $0.54(U)$ & $1.1(U)$ \\
\hline GBPB031012 & 2.5 & 240 & $0.56(\mathrm{U})$ & 13 & 9.9 & 0.003 (UJ) & $0.31(\mathrm{~B})$ & $1.1(U)$ \\
\hline GBPB031416 & 1.5 & 290 & $1.1(\mathrm{U})$ & 9.7 & 11 & 0.11 (UJ) & $1.1(\mathrm{U})$ & $1.1(\mathrm{U})$ \\
\hline
\end{tabular}

a Environmental Protection Agency Region IX Industrial Preliminary Remediation Goals (EPA, 1999a)

bSample is field duplicate of above sample.

'Sample collected at background location.

Darker shaded area $=$ Indicates analytical result exceeds PAL

$U=$ Undetected

$\mathrm{J}=$ Estimated value

$\mathrm{B}=$ Analyte found in associated blank

\section{C.5.1.5 Tritium Results}

The radioanalytical results for tritium are presented in Table C.5-5. There is no PAL for tritium. Samples were analyzed for tritium for two purposes, waste characterization and site characterization. The waste characterization samples were generally collected from a layer within the borehole in which drilling mud or other disturbed media could be identified. The site characterization samples were collected at arbitrary 4-ft intervals from four Boreholes, GBP14, GBP23, GBP24, and GBP25.

Boreholes GBP14, GBP23, and GBP25 were completed at locations where some of the highest levels of tritium were detected during the 1978 sampling event. Borehole GBP14 was located approximately $25 \mathrm{ft}$ east of the historic flare stack location. This is also the approximate location of profile set \#14 from the 1978 sampling event. Borehole GBP23 was located at the approximate 
Table C.5-5

Soil Sample Results for Tritium

\begin{tabular}{|c|c|c|c|c|c|}
\hline Purpose & Sample Number & $\begin{array}{l}\text { Tritium } \\
(\mathrm{pCi} / \mathrm{g})\end{array}$ & Purpose & Sample Number & $\begin{array}{l}\text { Tritium } \\
(\mathrm{pCi} / \mathrm{g})\end{array}$ \\
\hline WC & GBPS010609 & $0.033(\mathrm{UJ})$ & WC & GBPS170204 & 0.001 (UJ) \\
\hline WC & GBPS010911 & 0.039 (UJ) & WC & GBPS180911 & $1.6(\mathrm{~J})$ \\
\hline WC & GBPS020610 & $0.038(\mathrm{UJ})$ & WC & GBPS210204 & $0(\mathrm{UJ})$ \\
\hline WC & GBPS030406 & 0.037 (UJ) & \multirow{5}{*}{$\begin{array}{c}\text { Profile } \\
\text { samples } \\
\text { from location } \\
\text { of gas } / \text { water } \\
\text { separator }\end{array}$} & GBPS230304 & $0.008(U)$ \\
\hline WC & GBPS040406 & -0.004 (UJ) & & GBPS230708 & $0.011(U)$ \\
\hline WC & GBPS050408 & $0.024(\mathrm{UJ})$ & & GBPS231112 & $0.072(\mathrm{U})$ \\
\hline WC & GBPS060608 & $0.028(\mathrm{UJ})$ & & GBPS231516 & $0.079(U)$ \\
\hline WC & GBPS070608 & $0.142(\mathrm{~J})$ & & GBPS231920 & $0.261(\mathrm{LT})$ \\
\hline WC & GBPS100204 & -0.01 (UJ) & \multirow{4}{*}{$\begin{array}{c}\text { Profile } \\
\text { samples } \\
\text { from location } \\
\text { west of flare } \\
\text { stack }\end{array}$} & GBPS240304 & $0.011(U)$ \\
\hline WC & GBPS110204 & 0.001 (UJ) & & GBPS240506 & $0.07(U)$ \\
\hline WC & GBPS120204 & $-0.004(\mathrm{UJ})$ & & GBPS241112 & $0.007(U)$ \\
\hline \multirow{5}{*}{$\begin{array}{c}\text { Profile } \\
\text { samples from } \\
\text { location just } \\
\text { east of flare } \\
\text { stack }\end{array}$} & GBPS140304 & $0.263(\mathrm{~J})$ & & GBPS241416 & $0.005(U)$ \\
\hline & GBPS140708 & $7.32(\mathrm{~J})$ & \multirow{3}{*}{$\begin{array}{c}\text { Profile } \\
\text { samples } \\
\text { from location } \\
\text { of flare stack }\end{array}$} & GBPS250304 & $0.402(\mathrm{LT})$ \\
\hline & GBPS141112 & $3.36(\mathrm{~J})$ & & GBPS250708 & $0.56(\mathrm{LT})$ \\
\hline & GBPS141516 & $1.73(\mathrm{~J})$ & & GBPS251012 & $0.29(\mathrm{LT})$ \\
\hline & GBPS141920 & $2.5(\mathrm{~J})$ & & & \\
\hline
\end{tabular}

WC $=$ Waste characterization

$\mathrm{pCi} / \mathrm{g}=$ Picocuries per gram

$\mathrm{U}=$ Undetected

$\mathrm{J}=$ Estimated value

$\mathrm{LT}=$ Result is less than requested minimum detectable concentration (MDC), but greater than sample-specific MDC.

location of the gas/water separator used during flaring operations. This is also the approximate location of profile set \#1 from the 1978 sampling event. Borehole GBP25 was located at the approximate historic location of the flare stack and at the approximate location of profile set \#24 from the 1978 sampling event. The highest concentration of tritium in soil moisture (i.e., 1,303 pCi/mL) detected during the 1978 sampling was detected at this location. See Appendix A for results of the 1978 profile sampling. Borehole GBP24 was completed approximately $50 \mathrm{ft}$ west of the historic location of the flare stack and within Well GB-E Mud Pit A. 
Of the 31 soil samples analyzed for tritium, 5 samples produced results higher than 1.0 picocuries per gram (pCi/g). Four of these samples were collected from Borehole GBP14. The highest concentration of tritium detected was $7.32 \mathrm{pCi} / \mathrm{g}$ in sample GBPS 140708 collected at 7 to $8 \mathrm{ft}$ bgs. Samples taken in the same borehole below the depth of sample GBPS140708 indicate lower concentrations of tritium. Based on the preliminary dose/risk assessment provided in Appendix D, these levels do not pose a risk to human health.

\section{C.5.2 New Mexico Oil Conservation Division-Required Parameters}

A second category of parameters were analyzed for indirect comparison to the NM WQCC action levels listed in Title 20 NMAC 6.2.3103 "Standards for Ground Water of 10,000 mg/L Total Dissolved Solids Concentration or Less" (NMAC, 1996b). These parameters (i.e., TAL metals, boron, molybdenum, uranium, bromide, chloride, cyanide, fluoride, nitrates, sulfates, and radium-226/-228) were specified by the NM OCD to show drilling fluids and drill cuttings were disposed of "in a manner to prevent contamination to surface or subsurface waters," as stated in 19 NMAC 15.C.105 (NMAC, 1996b). Sampling activities for these parameters were designed to collect samples at locations where the potential for contamination was highest (i.e., from layers of drilling mud).

All characterization samples collected during the preliminary field investigation were soil samples (i.e., no groundwater was encountered), thus the results can not be directly compared to the NM WQCC water quality standards in 20 NMAC 6.2.3103 (NMAC, 1996a). The Region IX Industrial Soil PRGs (EPA, 1999a), are presented in association with the results for comparison. Further analysis of the data was not done at this time. This data may be used in the corrective action decision document to support decisions made on the closure of the mud pits.

\section{C.5.2.1 Target Analyte List Metals, Boron, Molybdenum, and Uranium Results}

The TAL metals (not including the RCRA metals) plus boron, molybdenum, and uranium analytical results above the minimum reporting limits, along with the associated Region IX PRGs (EPA, 1999a), as applicable, are presented in Table C.5-6. Nondetects were not reported to limit the length of the report. None of these COPCs were detected above the associated Region IX PRGs (EPA, 1999a). 
Table C.5-6

Soil Sample Results for TAL Metals (Except RCRA Metals) and Molybdenum, Boron, and Uranium

(Page 1 of 6 )

\begin{tabular}{|c|c|c|c|c|c|c|c|c|c|c|c|c|c|c|c|c|c|c|}
\hline \multirow[b]{2}{*}{ Sample No. } & \multicolumn{18}{|c|}{ Contaminants of Potential Concern $(\mathrm{mg} / \mathrm{kg})$} \\
\hline & 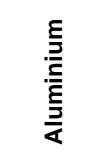 & 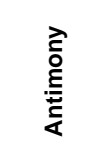 & 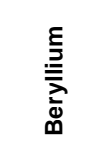 & $\begin{array}{l}\text { 힘 } \\
\text { Ф }\end{array}$ & $\begin{array}{l}\frac{E}{\mathrm{~J}} \\
\frac{\mathrm{J}}{\mathrm{J}} \\
\end{array}$ & $\begin{array}{l}\frac{5}{\pi} \\
\text { o̊ } \\
0\end{array}$ & $\begin{array}{l}\text { むँ } \\
\text { 잉 }\end{array}$ & 호 & 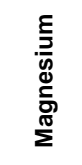 & 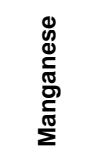 & 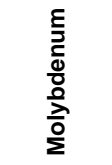 & $\begin{array}{l}\bar{\Phi} \\
\frac{\overline{0}}{\mathbf{Z}}\end{array}$ & 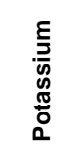 & 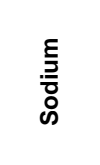 & 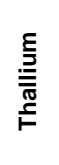 & 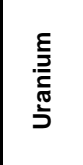 & 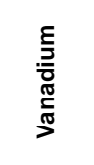 & 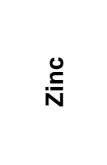 \\
\hline PRG $^{\mathbf{a}}$ & 100,000 & 820 & 2,200 & 79,000 & NA & 100,000 & 76,000 & 100,000 & NA & 32,000 & 10,000 & NA & NA & NA & NA & NA & 14,000 & 100,000 \\
\hline GBPS010609 & 7,300 & $0.84(\mathrm{~J})$ & 0.79 & -- & 4,100 & 8.1 & 16 & 24,000 & 2,100 & 270 & $0.95(\mathrm{~B})$ & 11 & $\begin{array}{c}1,400 \\
(\mathrm{~J})\end{array}$ & $350(\mathrm{~J})$ & -- & -- & 30 & 33 \\
\hline GBPS010911 & 6,700 & -- & 0.81 & -- & 4,900 & 5.7 & 13 & 12,000 & 1,900 & 230 & -- & 9.3 & $\begin{array}{c}1,300 \\
(\mathrm{~J})\end{array}$ & $\begin{array}{c}1,000 \\
(\mathrm{~J})\end{array}$ & -- & -- & 18 & 30 \\
\hline GBPS011214 & 14,000 & $1.2(\mathrm{~B})$ & 1.7 & -- & 9,500 & 9.7 & 46 & 30,000 & 4,700 & 700 & $1(\mathrm{~B})$ & 20 & 2,100 & 520 & -- & 53 & 54 & 63 \\
\hline GBPS011921 & 12,000 & $0.59(\mathrm{~B})$ & 1.3 & -- & 6,700 & 5.5 & 55 & 17,000 & 3,200 & 160 & $0.87(\mathrm{~B})$ & 11 & 2,400 & 990 & -- & 20 (B) & 47 & 51 \\
\hline GBPS020610 & 7,600 & $0.38(\mathrm{~J})$ & 0.66 & -- & 3,900 & 7.5 & 13 & 16,000 & 2,400 & 340 & $0.69(\mathrm{~B})$ & 10 & $\begin{array}{c}1,500 \\
(\mathrm{~J})\end{array}$ & $350(\mathrm{~J})$ & -- & 16 (B) & 25 & 38 \\
\hline GBPS021719 & 11,000 & $0.72(\mathrm{~B})$ & 1.2 & -- & 7,100 & 4 & 36 & 18,000 & 2,900 & 150 & -- & 10 & 1,500 & 320 & -- & -- & 39 & 41 \\
\hline GBPS030406 & 6,900 & $0.61(\mathrm{~J})$ & 0.62 & -- & 5,500 & 7 & 12 & 15,000 & 2,300 & 330 & -- & 9.8 & $\begin{array}{c}1,500 \\
(\mathrm{~J})\end{array}$ & $\begin{array}{c}1,100 \\
(J)\end{array}$ & -- & 12 (B) & 24 & 35 \\
\hline GBPS030911 & 7,800 & $0.44(B)$ & 0.7 & -- & 3,300 & 8 & 11 & 16,000 & 2,500 & 440 & -- & 11 & 1,100 & $100(B)$ & -- & -- & 25 & 35 \\
\hline GBPS031416 & 8,000 & -- & 0.68 & -- & 4,000 & 7.4 & 10 & 16,000 & 2,600 & 390 & -- & 10 & 910 & -- & -- & -- & 25 & 33 \\
\hline GBPS040406 & 9,000 & $0.41(\mathrm{~J})$ & 0.74 & -- & 3,100 & 7.7 & 12 & 18,000 & 2,500 & 420 & 0.64 (B) & 11 & $\begin{array}{c}1,600 \\
(\mathrm{~J})\end{array}$ & $190(\mathrm{~J})$ & -- & 34 & 28 & 38 \\
\hline GBPS040911 & 6,100 & $0.54(\mathrm{~B})$ & $0.52(\mathrm{~B})$ & -- & 2,300 & 6.5 & 8.3 & 13,000 & 2,000 & 340 & -- & 8.4 & 930 & 240 & -- & -- & 21 & 28 \\
\hline GBPS041416 & 8,600 & $0.81(\mathrm{~B})$ & 0.74 & -- & 3,400 & 7.9 & 11 & 17,000 & 2,700 & 430 & -- & 11 & 1,100 & 130 & -- & -- & 27 & 37 \\
\hline GBPS050408 & 9,600 & $0.65(\mathrm{~J})$ & 0.83 & -- & 3,700 & 8.7 & 13 & 19,000 & 2,800 & 520 & -- & 12 & $\begin{array}{c}1,600 \\
(\mathrm{~J})\end{array}$ & $140(\mathrm{~J})$ & -- & 34 & 30 & 42 \\
\hline GBPS051012 & 5,400 & $0.43(\mathrm{~B})$ & $0.49(\mathrm{~B})$ & -- & 2,300 & 5.9 & 7.8 & 12,000 & 1,900 & 300 & -- & 8 & 690 & -- & -- & -- & 19 & 26 \\
\hline
\end{tabular}


Table C.5-6

Soil Sample Results for TAL Metals (Except RCRA Metals) and Molybdenum, Boron, and Uranium

(Page 2 of 6 )

\begin{tabular}{|c|c|c|c|c|c|c|c|c|c|c|c|c|c|c|c|c|c|c|}
\hline \multirow[b]{2}{*}{ Sample No. } & \multicolumn{18}{|c|}{ Contaminants of Potential Concern $(\mathrm{mg} / \mathrm{kg})$} \\
\hline & 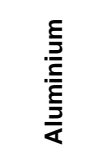 & 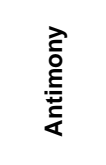 & 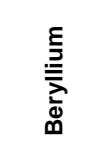 & $\begin{array}{l}\text { 힘 } \\
\text { Ф }\end{array}$ & $\begin{array}{l}\frac{E}{\mathrm{~J}} \\
\frac{\mathrm{J}}{\delta} \\
\end{array}$ & $\begin{array}{l}\frac{}{\pi} \\
\text { o̊ } \\
0\end{array}$ & $\begin{array}{l}\text { む) } \\
\text { 잉 }\end{array}$ & 호 & 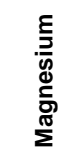 & 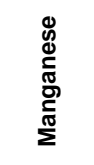 & 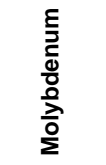 & $\begin{array}{l}\bar{\Phi} \\
\frac{\bar{d}}{z}\end{array}$ & 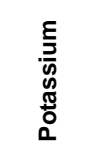 & $\begin{array}{l}\underline{\xi} \\
\text { 흫 } \\
\text { 心 }\end{array}$ & 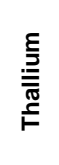 & 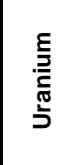 & 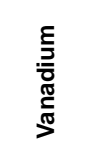 & $\stackrel{0}{\stackrel{0}{N}}$ \\
\hline PRG $^{\mathbf{a}}$ & 100,000 & 820 & 2,200 & 79,000 & NA & 100,000 & 76,000 & 100,000 & NA & 32,000 & 10,000 & NA & NA & NA & NA & NA & 14,000 & 100,000 \\
\hline GBPS051820 & 5,900 & $0.52(\mathrm{~B})$ & $0.51(\mathrm{~B})$ & -- & 3,100 & 6.9 & 7.8 & 13,000 & 2,000 & 370 & -- & 8.5 & 850 & -- & -- & -- & 21 & 27 \\
\hline GBPS0 $1^{\mathrm{b}}$ & 6,700 & $0.31(\mathrm{~B})$ & 0.57 & -- & 3,300 & 7.6 & 8.6 & 14,000 & 2,300 & 400 & -- & 9.7 & 950 & -- & -- & 16 (B) & 23 & 32 \\
\hline GBPS060608 & 5,200 & $0.35(\mathrm{~J})$ & 0.46 (B) & -- & 2,200 & 5.9 & 7.7 & 12,000 & 1,600 & 290 & -- & 7.5 & $780(\mathrm{~J})$ & $170(\mathrm{~J})$ & -- & -- & 19 & 31 \\
\hline GBPS061012 & 4,700 & -- & $0.42(\mathrm{~J})$ & -- & 1,700 & 6 & 6.2 & 10,000 & 1,600 & 320 & $0.64(\mathrm{~B})$ & 7.1 & $550(\mathrm{~J})$ & 470 & -- & -- & 16 & 23 \\
\hline GBPS061618 & 9,800 & -- & $1.2(\mathrm{~J})$ & -- & 5,600 & 11 & 23 & 20,000 & 3,500 & 310 & $0.71(\mathrm{~B})$ & 14 & $\begin{array}{c}1,200 \\
(\mathrm{~J})\end{array}$ & 180 & -- & 38 & 38 & 48 \\
\hline GBPS070608 & 7,800 & -- & 0.71 & -- & 4,500 & 6.5 & 13 & 17,000 & 2,500 & 240 & -- & 10 & $\begin{array}{c}1,300 \\
(\mathrm{~J})\end{array}$ & $410(\mathrm{~J})$ & -- & 20 (B) & 27 & 35 \\
\hline GBPS071012 & 6,400 & -- & $0.59(\mathrm{~J})$ & -- & 3,000 & 6.7 & 9.1 & 13,000 & 2,300 & 370 & -- & 9 & $940(\mathrm{~J})$ & 310 & -- & -- & 20 & 31 \\
\hline GBPS071618 & 5,700 & -- & $0.51(\mathrm{~J})$ & -- & 3,000 & 6.5 & 7.8 & 12,000 & 2,100 & 340 & -- & 8.3 & $730(\mathrm{~J})$ & 98 (B) & -- & -- & 19 & 27 \\
\hline GBPS080204 & 4,300 & -- & $0.39(\mathrm{~J})$ & -- & 2,000 & 5.4 & 8.4 & 9,700 & 1,700 & 260 & -- & 7.2 & $\begin{array}{c}1,300 \\
(\mathrm{~J})\end{array}$ & 170 & -- & -- & 17 & 28 \\
\hline GBPS081416 & 5,300 & -- & $0.51(\mathrm{~J})$ & -- & 2,400 & 7.2 & 7.9 & 13,000 & 1,900 & 350 & -- & 8.2 & $750(\mathrm{~J})$ & -- & -- & -- & 20 & 28 \\
\hline GBPS090204 & 7,400 & -- & $0.72(\mathrm{~J})$ & -- & 3,600 & 8.5 & 13 & 16,000 & 2,500 & 530 & -- & 11 & $\begin{array}{c}1,800 \\
\text { (J) }\end{array}$ & 160 & -- & 22 & 26 & 40 \\
\hline GBPS091416 & 5,100 & -- & $0.44(\mathrm{~J})$ & -- & 2,600 & 5.7 & 6.9 & 11,000 & 1,800 & 310 & -- & 7.4 & $780(\mathrm{~J})$ & -- & -- & -- & 17 & 24 \\
\hline GBPS100204 & 8,800 & $0.47(\mathrm{~J})$ & 0.75 & -- & 3,500 & 9.2 & 13 & 19,000 & 2,700 & 550 & $0.55(\mathrm{~B})$ & 12 & $\begin{array}{c}1,800 \\
(\mathrm{~J})\end{array}$ & $160(\mathrm{~J})$ & -- & 32 & 30 & 42 \\
\hline GBPS101416 & 8,500 & -- & $0.71(\mathrm{~J})$ & -- & 3,200 & 8.7 & 11 & 17,000 & 2,800 & 420 & -- & 11 & $\begin{array}{c}1,200 \\
(J)\end{array}$ & -- & -- & 14 (B) & 28 & 36 \\
\hline
\end{tabular}


Table C.5-6

Soil Sample Results for TAL Metals (Except RCRA Metals) and Molybdenum, Boron, and Uranium

(Page 3 of 6 )

\begin{tabular}{|c|c|c|c|c|c|c|c|c|c|c|c|c|c|c|c|c|c|c|}
\hline \multirow[b]{2}{*}{ Sample No. } & \multicolumn{18}{|c|}{ Contaminants of Potential Concern $(\mathrm{mg} / \mathrm{kg})$} \\
\hline & 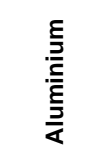 & 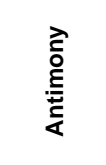 & & $\begin{array}{l}\text { 히 } \\
\text { ஸे }\end{array}$ & $\begin{array}{l}\frac{E}{\bar{J}} \\
\frac{0}{\delta} \\
\end{array}$ & $\begin{array}{l}\frac{5}{\pi} \\
\text { o } \\
0\end{array}$ & $\begin{array}{l}\text { む } \\
\frac{0}{0} \\
0\end{array}$ & 을 & 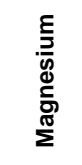 & 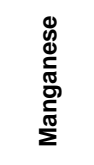 & 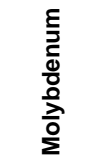 & $\begin{array}{l}\bar{\Phi} \\
\frac{d}{z}\end{array}$ & 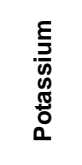 & 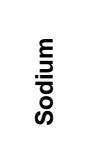 & 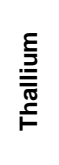 & 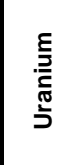 & 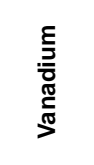 & 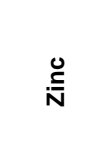 \\
\hline$P_{R G}{ }^{a}$ & 100,000 & 820 & 2,200 & 79,000 & NA & 100,000 & 76,000 & 100,000 & NA & 32,000 & 10,000 & NA & NA & NA & NA & NA & 14,000 & 100,000 \\
\hline GBPS110204 & 8,100 & $0.45(\mathrm{~J})$ & 0.7 & -- & 3,100 & 7.6 & 10 & 17,000 & 2,400 & 440 & -- & 10 & $\begin{array}{c}1,300 \\
(\mathrm{~J})\end{array}$ & $150(\mathrm{~J})$ & -- & 25 & 27 & 34 \\
\hline GBPS111416 & 8,200 & -- & $0.77(\mathrm{~J})$ & -- & 4,400 & 7.5 & 11 & 15,000 & 2,700 & 460 & -- & 11 & $\begin{array}{c}1,200 \\
(\mathrm{~J})\end{array}$ & -- & -- & $18(B)$ & 23 & 36 \\
\hline GBPS120204 & 14,000 & $0.87(\mathrm{~J})$ & 1.6 & -- & 8,700 & 12 & 44 & 22,000 & 4,600 & 340 & -- & 20 & $\begin{array}{c}2,000 \\
(\mathrm{~J})\end{array}$ & $660(\mathrm{~J})$ & -- & 38 & 39 & 68 \\
\hline GBPS120608 & 7,900 & -- & $0.78(\mathrm{~J})$ & -- & 17,000 & 7.8 & 15 & 16,000 & 2,900 & 380 & -- & 11 & $\begin{array}{c}1,300 \\
(\mathrm{~J})\end{array}$ & 770 & -- & $14(\mathrm{~B})$ & 22 & 40 \\
\hline GBPS 121719 & 10,000 & -- & $0.89(\mathrm{~J})$ & -- & 4,300 & 9 & 16 & 17,000 & 3,200 & 370 & -- & 13 & $\begin{array}{c}1,400 \\
(\mathrm{~J})\end{array}$ & 250 & -- & 31 & 26 & 43 \\
\hline GBPS 131920 & 7,400 & -- & $0.53(\mathrm{~J})$ & -- & 2,700 & 7 & 8.8 & 14,000 & 2,200 & 380 & $0.85(\mathrm{~B})$ & 9.1 & 1,100 & 68 (B) & -- & 14 (B) & 23 & 30 \\
\hline GBPS150204 & 6,200 & $0.5(\mathrm{~J})$ & $0.46(\mathrm{~J})$ & -- & 2,100 & 6.6 & 8.6 & 13,000 & 1,900 & 390 & $0.73(\mathrm{~B})$ & 8.2 & 1,400 & 260 & -- & $12(B)$ & 22 & 30 \\
\hline GBPS151416 & 11,000 & $0.66(\mathrm{~J})$ & $1.1(\mathrm{~J})$ & -- & 5,300 & 7.4 & 20 & 20,000 & 3,200 & 730 & $0.58(\mathrm{~B})$ & 19 & 1,400 & $88(B)$ & -- & 20 (B) & 35 & 42 \\
\hline GBPS160204 & 7,300 & $0.59(\mathrm{~J})$ & $0.55(\mathrm{~J})$ & -- & 2,700 & 7.7 & 10 & 16,000 & 2,200 & 460 & $0.99(\mathrm{~B})$ & 9.8 & 1,600 & 170 & -- & 24 & 26 & 36 \\
\hline $\mathrm{GBPS} 2^{\mathrm{b}}$ & 7,600 & $0.44(\mathrm{~B})$ & 0.57 & -- & 3,000 & 7.7 & 11 & 16,000 & 2,500 & 470 & $0.61(\mathrm{~B})$ & 9.8 & 1,700 & 180 & -- & 14 (B) & 26 & 37 \\
\hline GBPS 161416 & 10,000 & $0.68(\mathrm{~J})$ & $0.81(\mathrm{~J})$ & -- & 4,100 & 7.7 & 14 & 18,000 & 3,400 & 360 & -- & 11 & 1,800 & $99(\mathrm{~B})$ & -- & 28 & 27 & 48 \\
\hline GBPS170204 & 7,500 & $0.38(\mathrm{~J})$ & 0.66 & -- & 2,600 & 8.4 & 14 & 16,000 & 2,300 & 450 & $0.48(B)$ & 11 & $\begin{array}{c}1,600 \\
(\mathrm{~J})\end{array}$ & $130(\mathrm{~J})$ & -- & 26 & 28 & 37 \\
\hline GBPS171314 & 6,600 & $0.56(\mathrm{~J})$ & $0.49(\mathrm{~J})$ & -- & 2,400 & 7.1 & 8.3 & 14,000 & 2,200 & 380 & $0.53(\mathrm{~B})$ & 9 & 860 & $82(B)$ & -- & 19 (B) & 23 & 29 \\
\hline GBPS172123 & 10,000 & -- & $0.76(\mathrm{~J})$ & -- & 14,000 & 8.2 & 19 & 15,000 & 4,100 & 230 & -- & 13 & 1,300 & 200 & -- & -- & 22 & 50 \\
\hline
\end{tabular}


Table C.5-6

Soil Sample Results for TAL Metals (Except RCRA Metals) and Molybdenum, Boron, and Uranium

(Page 4 of 6 )

\begin{tabular}{|c|c|c|c|c|c|c|c|c|c|c|c|c|c|c|c|c|c|c|}
\hline \multirow[b]{2}{*}{ Sample No. } & \multicolumn{18}{|c|}{ Contaminants of Potential Concern $(\mathrm{mg} / \mathrm{kg})$} \\
\hline & 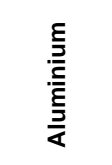 & 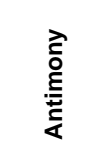 & 昙 & $\begin{array}{l}\text { 히 } \\
\text { ஸे }\end{array}$ & $\frac{\xi}{\frac{\xi}{0}}$ & $\begin{array}{l}\frac{5}{\pi} \\
\text { 。ํㅇ } \\
0\end{array}$ & $\begin{array}{l}\text { むँ } \\
\frac{0}{0} \\
0\end{array}$ & 호 & 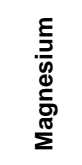 & 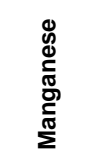 & 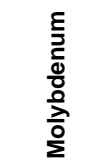 & $\begin{array}{l}\overline{\bar{d}} \\
\frac{\mathrm{d}}{\mathrm{z}}\end{array}$ & 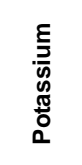 & 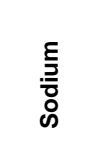 & 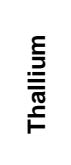 & 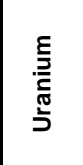 & 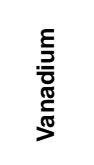 & $\stackrel{0}{\stackrel{\Xi}{N}}$ \\
\hline$P_{R G}{ }^{a}$ & 100,000 & 820 & 2,200 & 79,000 & NA & 100,000 & 76,000 & 100,000 & NA & 32,000 & 10,000 & NA & NA & NA & NA & NA & 14,000 & 100,000 \\
\hline GBPS180608 & 8,400 & $0.44(\mathrm{~J})$ & $0.64(\mathrm{~J})$ & -- & 3,800 & 7.2 & 12 & 16,000 & 2,500 & 270 & $0.82(\mathrm{~B})$ & 10 & 1,500 & 440 & -- & $15(B)$ & 26 & 39 \\
\hline GBPS180911 & 8,400 & $0.42(\mathrm{~J})$ & 0.72 & -- & 21,000 & 7.4 & 15 & 15,000 & 2,600 & 370 & $0.74(\mathrm{~B})$ & 11 & $\begin{array}{c}1,600 \\
(\mathrm{~J})\end{array}$ & $\begin{array}{c}1300 \\
(\mathrm{~J})\end{array}$ & -- & -- & 24 & 36 \\
\hline GBPS181416 & 7,600 & -- & $0.55(\mathrm{~J})$ & -- & 3,100 & 7.4 & 8.8 & 15,000 & 2,400 & 410 & 0.98 (B) & 9.6 & 910 & 210 & -- & 18 (B) & 25 & 32 \\
\hline GBPS182122 & 13,000 & $1.2(\mathrm{~J})$ & $1.5(\mathrm{~J})$ & -- & 11,000 & 5.9 & 24 & 29,000 & 3,400 & 230 & 0.98 (B) & 11 & 2,000 & 820 & -- & $30(B)$ & 68 & 50 \\
\hline GBPS 190204 & 9,600 & $0.84(\mathrm{~J})$ & $0.88(\mathrm{~J})$ & -- & 4,400 & 8.9 & 19 & 21,000 & 3,100 & 390 & 1.6 & 13 & 1,800 & 200 & -- & -- & 33 & 46 \\
\hline GBPS191416 & 5,000 & $0.57(\mathrm{~B})$ & $0.38(\mathrm{~B})$ & -- & 1,800 & 4.4 & 6.9 & 11,000 & 1,500 & 220 & -- & 6.2 & 610 & $64(\mathrm{~B})$ & -- & -- & 19 & 21 \\
\hline GBPS200204 & 7,600 & $0.33(\mathrm{~J})$ & $0.7(\mathrm{~J})$ & -- & 5,900 & 7.2 & 15 & 16,000 & 2,500 & 360 & -- & 10 & 1,700 & 390 & -- & 14 (B) & 23 & 39 \\
\hline GBPS201416 & 7,100 & $0.32(\mathrm{~J})$ & $0.53(\mathrm{~J})$ & -- & 3,700 & 6.6 & 8.3 & 14,000 & 2,200 & 350 & -- & 9 & 880 & $70(B)$ & -- & 14 (B) & 23 & 28 \\
\hline GBPS210204 & 11,000 & -- & 1.3 & -- & 13,000 & 8.1 & 36 & 17,000 & 3,500 & 200 & -- & 15 & $\begin{array}{c}1,700 \\
(\mathrm{~J})\end{array}$ & $230(\mathrm{~J})$ & -- & -- & 31 & 51 \\
\hline GBPS210608 & 6,100 & $0.46(\mathrm{~B})$ & 0.46 (B) & -- & 2,200 & 5.5 & 6.2 & 12,000 & 1,700 & 290 & -- & 7.6 & 1,100 & $63(B)$ & -- & -- & 21 & 24 \\
\hline GBPS211416 & 11,000 & $0.63(\mathrm{~B})$ & 0.89 & -- & 4,300 & 9.4 & 15 & 20,000 & 3,200 & 370 & -- & 12 & 1,400 & 330 & -- & 28 & 35 & 39 \\
\hline GBPS220204 & 14,000 & $0.83(\mathrm{~B})$ & 1.4 & -- & 8,400 & 13 & 31 & 28,000 & 4,800 & 330 & -- & 19 & 1,400 & 320 & -- & -- & 38 & 73 \\
\hline GBPS221416 & 14,000 & $0.91(\mathrm{~B})$ & 1.4 & -- & 6,700 & 17 & 49 & 32,000 & 6,900 & 410 & -- & 27 & 2,600 & 720 & -- & 48 & 49 & 96 \\
\hline GBPS $03^{b}$ & 14,000 & $1.1(\mathrm{~B})$ & 1.4 & -- & 6,200 & 16 & 43 & 33,000 & 6,500 & 400 & -- & 27 & 2,700 & 710 & $\begin{array}{c}0.85 \\
\text { (B) }\end{array}$ & 43 (B) & 50 & 94 \\
\hline GBPS222021 & 11,000 & $0.9(\mathrm{~B})$ & 0.93 & -- & 5,100 & 12 & 24 & 22,000 & 5,100 & 280 & -- & 19 & 2,200 & 610 & -- & 54 & 31 & 70 \\
\hline
\end{tabular}


Table C.5-6

Soil Sample Results for TAL Metals (Except RCRA Metals) and Molybdenum, Boron, and Uranium

(Page 5 of 6 )

\begin{tabular}{|c|c|c|c|c|c|c|c|c|c|c|c|c|c|c|c|c|c|c|}
\hline \multirow[b]{2}{*}{ Sample No. } & \multicolumn{18}{|c|}{ Contaminants of Potential Concern $(\mathrm{mg} / \mathrm{kg})$} \\
\hline & 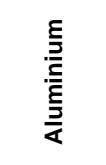 & 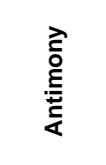 & 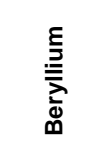 & $\begin{array}{l}\text { 힘 } \\
\text { Ф }\end{array}$ & $\begin{array}{l}\frac{E}{\mathrm{~J}} \\
\frac{\mathrm{J}}{\delta} \\
\end{array}$ & $\begin{array}{l}\frac{}{\pi} \\
\text { o̊ } \\
0\end{array}$ & $\begin{array}{l}\text { む) } \\
\text { 잉 }\end{array}$ & 호 & 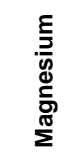 & 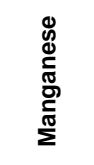 & 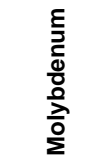 & $\begin{array}{l}\bar{\Phi} \\
\frac{\bar{d}}{z}\end{array}$ & 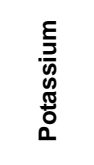 & 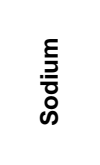 & 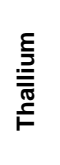 & 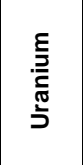 & 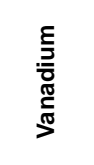 & 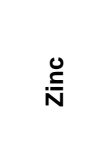 \\
\hline PRG $^{\mathbf{a}}$ & 100,000 & 820 & 2,200 & 79,000 & NA & 100,000 & 76,000 & 100,000 & NA & 32,000 & 10,000 & NA & NA & NA & NA & NA & 14,000 & 100,000 \\
\hline GBPS240506 & 7,800 & -- & 0.82 & -- & 6,800 & $7.6(\mathrm{~J})$ & 24 & 16,000 & 2,800 & 270 & $0.52(\mathrm{~B})$ & 14 & 1,800 & 1,600 & -- & -- & $21(\mathrm{~J})$ & 41 \\
\hline GBPS241416 & 13,000 & -- & 0.96 & -- & 4,600 & $9.6(\mathrm{~J})$ & 14 & 23,000 & 3,800 & 510 & -- & 14 & 1,700 & $96(\mathrm{~B})$ & -- & 34 & $33(\mathrm{~J})$ & 48 \\
\hline GBPS250507 & 9,900 & -- & 0.73 & $9.7(\mathrm{~J})$ & 16,000 & $7.6(\mathrm{~J})$ & 13 & 16,000 & 2,600 & 310 & -- & 10 & 2,000 & 500 & -- & 16 (B) & $26(\mathrm{~J})$ & 41 \\
\hline GBPS251012 & 12,000 & -- & 0.97 & -- & 4,700 & $9.9(\mathrm{~J})$ & 15 & 22,000 & 3,500 & 560 & $0.92(B)$ & 14 & 2,000 & $100(B)$ & -- & 25 & $32(\mathrm{~J})$ & 48 \\
\hline GBPS260204 & 4,400 & $0.65(\mathrm{~B})$ & 0.38 (B) & -- & 1,700 & 5 & 5.4 & 9,900 & 1,500 & 290 & -- & 6.4 & 800 & 98 (B) & -- & -- & 16 & 23 \\
\hline GBPS261416 & 5,700 & -- & $0.5(\mathrm{~B})$ & -- & 2,800 & 6.5 & 7.9 & 12,000 & 2,000 & 350 & -- & 8.4 & 760 & -- & -- & -- & 18 & 26 \\
\hline $\mathrm{GBPS} 4^{\mathrm{b}}$ & 7,200 & $0.42(\mathrm{~J})$ & $0.58(\mathrm{~J})$ & -- & 5,500 & 6.4 & 8.7 & 14,000 & 2,200 & 370 & $0.52(B)$ & 8.9 & $\begin{array}{c}1,000 \\
\text { (J) }\end{array}$ & -- & -- & -- & 24 & 30 \\
\hline GBPS270204 & 5,500 & $0.61(\mathrm{~J})$ & $0.47(\mathrm{~J})$ & -- & 2,300 & 5.8 & 7.2 & 12,000 & 1,800 & 340 & -- & 7.4 & $\begin{array}{c}1,100 \\
\text { (J) }\end{array}$ & $120(\mathrm{~J})$ & -- & 16 (B) & 20 & 34 \\
\hline GBPS271416 & 6,600 & $0.36(\mathrm{~J})$ & $0.53(\mathrm{~J})$ & -- & 4,900 & 6 & 7.9 & 12,000 & 2,000 & 350 & $0.54(\mathrm{~B})$ & 8.3 & $960(\mathrm{~J})$ & -- & -- & $13(\mathrm{~B})$ & 22 & 28 \\
\hline GBPS280608 & 9,300 & $0.68(\mathrm{~J})$ & $0.83(\mathrm{~J})$ & 13 & 15,000 & 8.2 & 17 & 17,000 & 2,900 & 460 & 1.1 & 11 & $\begin{array}{c}1,800 \\
\text { (J) }\end{array}$ & $690(\mathrm{~J})$ & -- & 17 (B) & 25 & 47 \\
\hline GBPS281012 & 10,000 & $0.83(\mathrm{~J})$ & $0.92(\mathrm{~J})$ & -- & 4,700 & 9.1 & 14 & 19,000 & 3,200 & 500 & $1.1(B)$ & 13 & $\begin{array}{c}1,700 \\
(\mathrm{~J})\end{array}$ & $120(\mathrm{~J})$ & -- & 35 & 30 & 42 \\
\hline GBPS282224 & 6,100 & $0.55(\mathrm{~J})$ & $0.55(\mathrm{~J})$ & -- & 2,600 & 7.1 & 8.7 & 13,000 & 2,100 & 420 & $0.64(\mathrm{~B})$ & 8.9 & $950(\mathrm{~J})$ & -- & -- & 12 (B) & 21 & 33 \\
\hline GBPS283032 & 7,600 & $0.44(\mathrm{~J})$ & $0.65(\mathrm{~J})$ & -- & 3,400 & 10 & 9.2 & 16,000 & 2,400 & 640 & $0.5(B)$ & 13 & $\begin{array}{c}1,100 \\
(\mathrm{~J})\end{array}$ & -- & -- & 19 (B) & 26 & 47 \\
\hline GBPS283436 & 8,500 & $0.66(\mathrm{~J})$ & $0.89(\mathrm{~J})$ & -- & 4,700 & 15 & 15 & 19,000 & 2,800 & 370 & -- & 14 & $\begin{array}{c}1,000 \\
(J)\end{array}$ & $170(\mathrm{~J})$ & -- & 29 & 30 & 39 \\
\hline
\end{tabular}


Table C.5-6

Soil Sample Results for TAL Metals (Except RCRA Metals) and Molybdenum, Boron, and Uranium

(Page 6 of 6 )

\begin{tabular}{|c|c|c|c|c|c|c|c|c|c|c|c|c|c|c|c|c|c|c|}
\hline \multirow[b]{2}{*}{ Sample No. } & \multicolumn{18}{|c|}{ Contaminants of Potential Concern $(\mathrm{mg} / \mathrm{kg})$} \\
\hline & 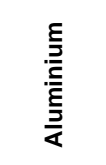 & 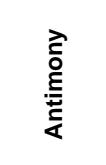 & 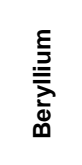 & $\begin{array}{l}\text { 히 } \\
\text { ஸे }\end{array}$ & $\frac{\xi}{\frac{\xi}{0}}$ & $\begin{array}{l}\frac{T}{\pi} \\
\text { o̊ } \\
0\end{array}$ & $\begin{array}{l}\text { むँ } \\
\frac{0}{0} \\
0\end{array}$ & 흔 & 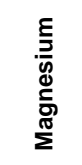 & 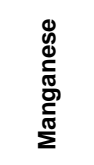 & 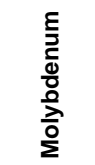 & $\begin{array}{l}\overline{\bar{d}} \\
\frac{\mathrm{d}}{\mathrm{z}}\end{array}$ & 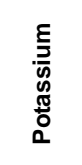 & 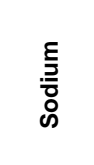 & 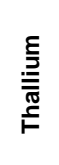 & 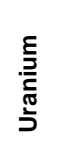 & 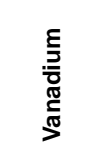 & $\stackrel{0}{\stackrel{\Xi}{N}}$ \\
\hline$P_{R G}{ }^{a}$ & 100,000 & 820 & 2,200 & 79,000 & NA & 100,000 & 76,000 & 100,000 & NA & 32,000 & 10,000 & NA & NA & NA & NA & NA & 14,000 & 100,000 \\
\hline GBPS290103 & 12,000 & $0.65(J)$ & $1(\mathrm{~J})$ & -- & 5,700 & 11 & 21 & 21,000 & 3,900 & 720 & -- & 17 & $\begin{array}{c}1,400 \\
(\mathrm{~J})\end{array}$ & $160(J)$ & -- & -- & 39 & 59 \\
\hline GBPS291416 & 12,000 & $0.66(J)$ & $1(\mathrm{~J})$ & -- & 5,200 & 8.2 & 20 & 21,000 & 3,600 & 220 & -- & 13 & $\begin{array}{c}1,100 \\
(\mathrm{~J})\end{array}$ & $160(\mathrm{~J})$ & -- & 47 & 38 & 47 \\
\hline GBPB010204 & 7,300 & $0.52(\mathrm{~B})$ & 0.56 & -- & 3,200 & 6.2 & 6.9 & 14,000 & 2,700 & 370 & -- & 8.9 & 780 & -- & -- & -- & 21 & 31 \\
\hline GBPB010912 & 12,000 & $0.54(\mathrm{~B})$ & 0.83 & -- & 6,400 & 9.6 & 13 & 21,000 & 5,200 & 460 & -- & 14 & 1,100 & 390 & -- & -- & 28 & 48 \\
\hline GBPB $030407^{\circ}$ & 8,200 & $0.51(\mathrm{~B})$ & 0.77 & -- & 3,900 & 8.1 & 11 & 16,000 & 2,700 & 390 & -- & 11 & 1,100 & $85(B)$ & -- & -- & 24 & 35 \\
\hline GBPB031012 & 10,000 & $0.45(B)$ & 0.93 & -- & 5,100 & 8.8 & 15 & 18,000 & 3,300 & 390 & -- & 13 & 1,400 & 310 & -- & -- & 30 & 45 \\
\hline GBPB031416 & 9,600 & $0.95(\mathrm{~B})$ & 1.4 & -- & 7,200 & 5.8 & 20 & 22,000 & 2,700 & 230 & -- & 14 & 1,600 & 420 & -- & -- & 47 & 45 \\
\hline
\end{tabular}

${ }^{a}$ Environmental Protection Agency Region IX Industrial Preliminary Remediation Goals (EPA, 1999a)

${ }^{b}$ Sample is field duplicate of above sample.

'Sample collected at background location.

$\mathrm{J}=$ Estimated value

$\mathrm{B}=$ Analyte found in associated blank 


\section{C.5.2.2 Bromide, Chloride, Fluoride, Nitrates, Sulfate, and Cyanide Results}

The bromide, chloride, fluoride, nitrates, sulfate, and cyanide analytical results above the minimum reporting limits, along with the associated Region IX PRGs (EPA, 1999a), as applicable, are presented in Table C.5-7. Nondetects were not reported to limit the length of report. None of these COPCs were detected above the associated Region IX PRGs (EPA, 1999a).

\section{C.5.2.3 Radium Results}

The radioanalytical results for radium are presented in Table C.5-8. Radium is not a COPC associated with underground nuclear detonations or other DOE activities at the site.

\section{C.5.3 Waste Characterization Parameters}

Additional parameters including TCLP metals, TCLP VOCs, and TCLP SVOCs, were analyzed for use in characterization of investigation-derived waste. The EPA regulatory limits for hazardous waste (CFR, 1999) are presented in association with the results of these analyses.

\section{C.5.3.1 Toxicity Characteristic Leaching Procedure Metal Results}

The TCLP metals analytical results above the minimum reporting limits, along with the associated regulatory limit (CFR, 1999), are presented in Table C.5-9. Nondetects were not reported to limit the length of the report. No COPCs were detected above regulatory limits.

\section{C.5.3.2 Toxicity Characteristic Leaching Procedure Volatile Organic Compound and Semivolatile Organic Compound Results}

The TCLP VOCs and TCLP SVOCs analytical results above the minimum reporting limits, along with the associated regulatory limit (CFR, 1999), are presented in Table C.5-10. Nondetects were not reported to limit the length of the report. None of these COPCs were detected above the regulatory limits.

\section{C.5.4 Rejected Data}

The data presented in Table C.5-11 was rejected (not usable for site characterization). These constituents, except for antimony, were not detected in other site characterization samples. Antimony was detected at very low levels (i.e., $<2 \mathrm{mg} / \mathrm{kg}$ ), in comparison to the PRG (i.e., $820 \mathrm{mg} / \mathrm{kg}$ ). Rejected data did not impact the characterization. 
Table C.5-7

Soil Sample Results for Bromide, Chloride, Fluoride, Nitrates, Sulfate, and Cyanide (Detects Only)

\begin{tabular}{|c|c|c|c|c|c|c|}
\hline \multirow{2}{*}{ Sample Numbers } & \multicolumn{6}{|c|}{ Contaminants of Potential Concern $(\mathrm{mg} / \mathrm{kg}$ ) } \\
\hline & Bromide & Chloride & Fluoride & Nitrate & Sulfate & Cyanide \\
\hline $\mathbf{P R G}^{\mathrm{a}}$ & NA & NA & 53,000 & NA & NA & NA \\
\hline GBPS010609 & -- & 5 & 5.3 & $1.8(\mathrm{~J})$ & 39 & -- \\
\hline GBPS010911 & -- & 6.7 & 7.5 & $2.3(\mathrm{~J})$ & 43 & -- \\
\hline GBPS020610 & $1.2(\mathrm{~J})$ & 4.3 & $2.4(\mathrm{~J})$ & 11 & 150 & $0.5(\mathrm{~J})$ \\
\hline GBPS030406 & -- & 7 & $4.2(\mathrm{~J})$ & 2.9 & 480 & 0.29 (J) \\
\hline GBPS040406 & -- & $2.2(\mathrm{~J})$ & $3.9(\mathrm{~J})$ & 2.6 & 16 & $0.41(\mathrm{~J})$ \\
\hline GBPS050408 & -- & 2.7 & $4.3(\mathrm{~J})$ & 3.2 & 41 & $0.44(\mathrm{~J})$ \\
\hline GBPS060608 & -- & $1.2(\mathrm{~J})$ & $2(\mathrm{~J})$ & $1.3(\mathrm{~J})$ & $41(\mathrm{~J})$ & -- \\
\hline GBPS070608 & -- & $12(\mathrm{~J})$ & $8.2(\mathrm{~J})$ & $3.9(\mathrm{~J})$ & 130 (J) & -- \\
\hline GBPS100204 & -- & $1(\mathrm{~J})$ & $3.7(\mathrm{~J})$ & $2.3(\mathrm{~J})$ & $53(\mathrm{~J})$ & -- \\
\hline GBPS110204 & -- & $1.1(\mathrm{~J})$ & $4.5(\mathrm{~J})$ & $1.3(\mathrm{~J})$ & $36(\mathrm{~J})$ & -- \\
\hline GBPS120204 & -- & $3.6(\mathrm{~J})$ & $13(\mathrm{~J})$ & $1.8(\mathrm{~J})$ & 110 (J) & -- \\
\hline GBPS170204 & -- & 4.6 & 3.7 & 2.3 & 16 & $0.25(\mathrm{~J})$ \\
\hline GBPS180911 & $1.4(\mathrm{~J})$ & 120 & 6.9 & 3.8 & 380 & $0.42(\mathrm{~J})$ \\
\hline GBPS210204 & -- & $2(\mathrm{~J})$ & $6.7(\mathrm{~J})$ & $1.4(\mathrm{~J})$ & $17(\mathrm{~J})$ & -- \\
\hline GBPS270204 & -- & $1.7(\mathrm{~J})$ & 1.5 & $2(\mathrm{~J})$ & 70 & -- \\
\hline GBPS271416 & -- & 10 & 5.3 & $1.3(\mathrm{~J})$ & $6.1(\mathrm{~J})$ & -- \\
\hline GBPB010204 & -- & $1.1(\mathrm{~J})$ & $2.7(\mathrm{~J})$ & $1.2(\mathrm{~J})$ & 16 & -- \\
\hline GBPB010912b & -- & 66 & $9.1(\mathrm{~J})$ & $1.9(\mathrm{~J})$ & 42 & -- \\
\hline GBPB030407b & -- & 3.4 & $4.8(\mathrm{~J})$ & $1.9(\mathrm{~J})$ & 8.7 (J) & -- \\
\hline GBPB031012 & -- & 27 & $14(\mathrm{~J})$ & $1.2(\mathrm{~J})$ & 32 & -- \\
\hline GBPB031416 & -- & 11 & $13(\mathrm{~J})$ & $1.3(\mathrm{~J})$ & 63 & -- \\
\hline
\end{tabular}

aEnvironmental Protection Agency Region IX Industrial Preliminary Remediation Goals (EPA, 1999a)

bSample collected at background location.

NA = Not applicable (There is no Region IX Industrial Preliminary Remediation Goals for this constituent) -- = Analyte not detected above minimum reporting limits.

$\mathrm{J}=$ Estimated value 
Table C.5-8

Soil Sample Results for Radium-226 and Radium-228

\begin{tabular}{|c|c|c|}
\hline Sample Number & $\begin{array}{l}\text { Radium-226 } \\
(\mathrm{pCi} / \mathrm{g})\end{array}$ & $\begin{array}{l}\text { Radium-228 } \\
(\mathrm{pCi} / \mathrm{g})\end{array}$ \\
\hline GBPS010609 & 1.54 & 1.36 \\
\hline GBPS010911 & 1.5 & 1.3 \\
\hline GBPS020610 & 1.38 & 1.03 \\
\hline GBPS030406 & 1.4 & 1.29 \\
\hline GBPS040406 & 1.54 & 1.06 \\
\hline GBPS050408 & 1.62 & 1.43 \\
\hline GBPS060608 & 1.49 & 1.47 \\
\hline GBPS070608 & 2.4 & 1.93 \\
\hline GBPS100204 & 1.49 & 1.2 \\
\hline GBPS110204 & 1.77 & 0.96 \\
\hline GBPS120204 & 3.06 & 2.52 \\
\hline GBPS170204 & 1.44 & 1.13 \\
\hline GBPS180911 & 1.73 & 1.17 \\
\hline GBPS210204 & 2.49 & 2.29 \\
\hline GBPB010204 ${ }^{a}$ & 1.32 & 1.26 \\
\hline GBPB010912 $^{a}$ & 1.56 & 1.69 \\
\hline GBPB030407 ${ }^{a}$ & 1.83 & 1.25 \\
\hline GBPB031012 & 1.99 & 1.33 \\
\hline GBPB031416 ${ }^{a}$ & 2.86 & 2.15 \\
\hline
\end{tabular}

${ }^{\mathrm{a}}$ Sample collected at background location. 
Table C.5-9

Soil Sample Results for TCLP Metals (Detects Only)

\begin{tabular}{||c|c|c|c||}
\hline \multirow{2}{*}{ Sample Number } & \multicolumn{2}{|c|}{ Constituents of Potential Concern } \\
(mg/L)
\end{tabular}

a40 CFR 261.24, "Identification and Listing of Hazardous Waste" (CFR, 1999)

-- = Analyte not detected above minimum reporting limits.

$B=$ Analyte found in associated blank 
Table C.5-10

TCLP VOCs and SVOCs (Detects Only)

\begin{tabular}{|c|c|c|}
\hline \multirow{2}{*}{ Sample Number } & \multicolumn{2}{|c|}{$\begin{array}{l}\text { Contaminants of Potential Concern } \\
\qquad(\mathrm{mg} / \mathrm{L})\end{array}$} \\
\hline & Chloroform & 2-Butanone (MEK) \\
\hline Regulatory Limit ${ }^{a}$ & 6.0 & 200 \\
\hline GBPS020610 & $0.00099(\mathrm{~J})$ & -- \\
\hline GBPS060608 & -- & $.0073(\mathrm{~J})$ \\
\hline GBPS070608 & $.0067(\mathrm{~J})$ & $0.00023(\mathrm{~J})$ \\
\hline GBPS110204 & $.0064(\mathrm{~J})$ & -- \\
\hline
\end{tabular}

a40 CFR 261.24, "Identification and Listing of Hazardous Waste" (CFR, 1999)

MEK = Methyl ethyl ketone

$--=$ Analyte not detected above minimum reporting limits.

$\mathrm{J}=$ Estimated value 
Table C.5-11

Rejected Data

(Page 1 of 2)

\begin{tabular}{|c|c|c|c|c|c|c|c|c|c|c|c|c|c|c|c|c|c|c|}
\hline \multirow[b]{3}{*}{$\begin{array}{l}\text { Sample } \\
\text { Number }\end{array}$} & \multicolumn{18}{|c|}{ Contaminants of Potential Concern ${ }^{a}$} \\
\hline & $\begin{array}{c}\text { Metals } \\
(\mathrm{mq} / \mathrm{kq})\end{array}$ & \multicolumn{13}{|c|}{ VOCs $(\mu \mathrm{g} / \mathbf{k g})$} & \multicolumn{4}{|c|}{ SVOCs $(\mu \mathrm{g} / \mathbf{k g})$} \\
\hline & 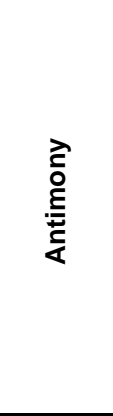 & 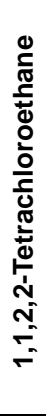 & 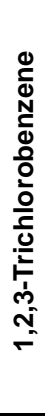 & 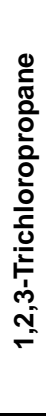 & 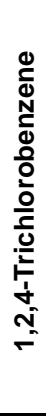 & 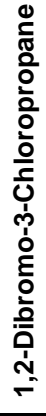 & 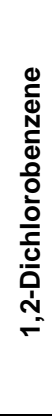 & 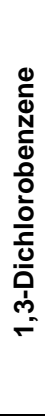 & 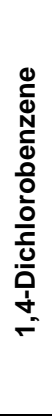 & 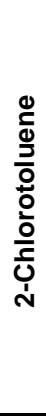 & 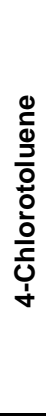 & 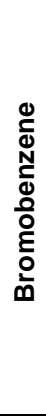 & 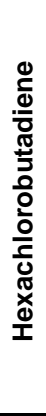 & 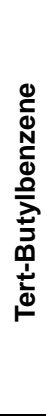 & 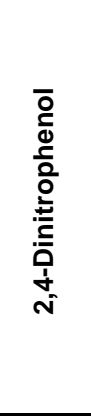 & 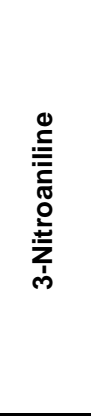 & 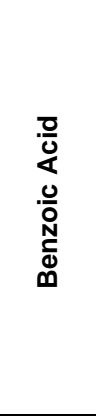 & 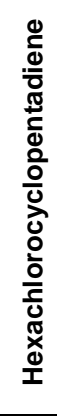 \\
\hline GBPB010204 & -- & -- & -- & -- & -- & -- & -- & -- & -- & -- & -- & -- & -- & -- & 1,800 & -- & 1,800 & 350 \\
\hline GBPB010912 & -- & -- & -- & -- & -- & -- & -- & -- & -- & -- & -- & -- & -- & -- & 1,800 & -- & 1,800 & 360 \\
\hline GBPB030407 & -- & -- & -- & -- & -- & -- & -- & -- & -- & -- & -- & -- & -- & -- & -- & -- & 1,800 & 360 \\
\hline GBPB031012 & -- & -- & -- & -- & -- & -- & -- & -- & -- & -- & -- & -- & -- & -- & -- & -- & 1,900 & 370 \\
\hline GBPB031416 & -- & -- & -- & -- & -- & -- & -- & -- & -- & -- & -- & -- & -- & -- & -- & -- & 1,900 & 370 \\
\hline GBPS010609 & -- & -- & -- & -- & -- & -- & -- & -- & -- & -- & -- & -- & -- & -- & -- & 2,000 & -- & -- \\
\hline GBPS010911 & -- & -- & -- & -- & -- & -- & -- & -- & -- & -- & -- & -- & -- & -- & -- & 2,000 & -- & 370 \\
\hline GBPS020610 & -- & -- & -- & -- & -- & -- & -- & -- & -- & -- & -- & -- & -- & -- & -- & 1,900 & -- & -- \\
\hline GBPS030911 & -- & -- & -- & -- & -- & -- & -- & -- & -- & -- & -- & -- & -- & -- & -- & -- & -- & 370 \\
\hline GBPS031416 & -- & -- & -- & -- & -- & -- & -- & -- & -- & -- & -- & -- & -- & -- & -- & -- & -- & 380 \\
\hline GBPS040406 & -- & -- & -- & -- & -- & -- & -- & -- & -- & -- & -- & -- & -- & -- & -- & 1,900 & -- & -- \\
\hline GBPS041416 & -- & -- & -- & -- & -- & -- & -- & -- & -- & -- & -- & -- & -- & -- & -- & -- & -- & 380 \\
\hline GBPS051012 & -- & -- & -- & -- & -- & -- & -- & -- & -- & -- & -- & -- & -- & -- & -- & -- & -- & 350 \\
\hline GBPS051820 & -- & -- & -- & -- & -- & -- & -- & -- & -- & -- & -- & -- & -- & -- & -- & -- & -- & 370 \\
\hline GBPS $01^{\mathrm{b}}$ & -- & -- & -- & -- & -- & -- & -- & -- & -- & -- & -- & -- & -- & -- & -- & -- & -- & 370 \\
\hline GBPS060608 & -- & -- & -- & -- & -- & -- & -- & -- & -- & -- & -- & -- & -- & -- & -- & 1,700 & -- & -- \\
\hline GBPS170204 & -- & -- & -- & -- & -- & -- & -- & -- & -- & -- & -- & -- & -- & -- & -- & 1,800 & -- & -- \\
\hline GBPS180911 & -- & -- & -- & -- & -- & -- & -- & -- & -- & -- & -- & -- & -- & -- & -- & 2,300 & -- & -- \\
\hline GBPS210608 & -- & -- & -- & -- & -- & -- & -- & -- & -- & -- & -- & -- & -- & -- & -- & -- & -- & 360 \\
\hline GBPS211416 & -- & -- & -- & -- & -- & -- & -- & -- & -- & -- & -- & -- & -- & -- & -- & -- & -- & 390 \\
\hline GBPS220204 & -- & -- & -- & -- & -- & -- & -- & -- & -- & -- & -- & -- & -- & -- & -- & -- & -- & 370 \\
\hline GBPS221416 & -- & -- & -- & -- & -- & -- & -- & -- & -- & -- & -- & -- & -- & -- & -- & -- & -- & 370 \\
\hline $\mathrm{GBPS} 3^{\mathrm{b}}$ & -- & -- & -- & -- & -- & -- & -- & -- & -- & -- & -- & -- & -- & -- & -- & -- & -- & 370 \\
\hline
\end{tabular}


Table C.5-11

Rejected Data

(Page 2 of 2)

\begin{tabular}{|c|c|c|c|c|c|c|c|c|c|c|c|c|c|c|c|c|c|c|}
\hline \multirow[b]{3}{*}{$\begin{array}{l}\text { Sample } \\
\text { Number }\end{array}$} & \multicolumn{18}{|c|}{ Contaminants of Potential Concern ${ }^{a}$} \\
\hline & $\begin{array}{l}\text { Metals } \\
(\mathrm{mg} / \mathrm{kg})\end{array}$ & \multicolumn{13}{|c|}{ VOCs ( $\mu \mathrm{g} / \mathbf{k g})$} & \multicolumn{4}{|c|}{ SVOCs $(\mu \mathrm{g} / \mathbf{k g})$} \\
\hline & $\begin{array}{l}\text { 등 } \\
\text { 들 } \\
\frac{\underline{z}}{4}\end{array}$ & 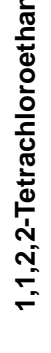 & 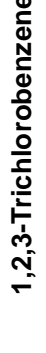 & 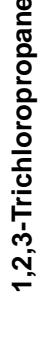 & 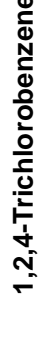 & 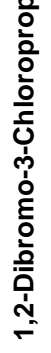 & 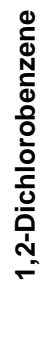 & 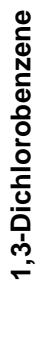 & 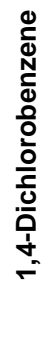 & 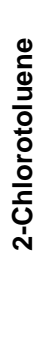 & 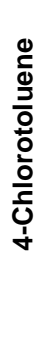 & 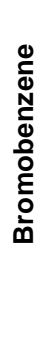 & 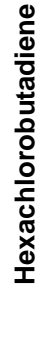 & 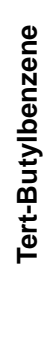 & 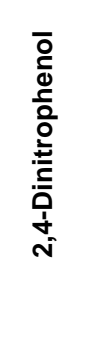 & 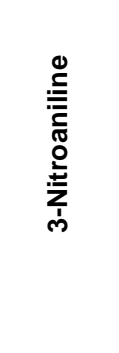 & 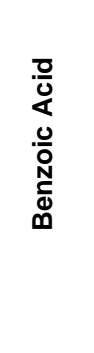 & 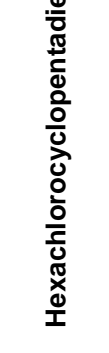 \\
\hline GBPS222021 & -- & -- & -- & -- & -- & -- & -- & -- & -- & -- & -- & -- & -- & -- & -- & -- & -- & 370 \\
\hline GBPS240506 & 0.6 & -- & -- & -- & -- & -- & -- & -- & -- & -- & -- & -- & -- & -- & -- & -- & -- & 1,600 \\
\hline GBPS241416 & 2.3 & -- & -- & -- & -- & -- & -- & -- & -- & -- & -- & -- & -- & -- & -- & -- & 2,000 & 390 \\
\hline GBPS250507 & 2.2 & 28 & 28 & 28 & 28 & 56 & 28 & 28 & 28 & 28 & 28 & 28 & 28 & 28 & -- & -- & -- & 370 \\
\hline GBPS251012 & 0.48 & -- & -- & -- & -- & -- & -- & -- & -- & -- & -- & -- & -- & -- & -- & -- & -- & 390 \\
\hline GBPS260204 & -- & -- & -- & -- & -- & -- & -- & -- & -- & -- & -- & -- & -- & -- & 1,700 & -- & 1,700 & 350 \\
\hline GBPS261416 & -- & -- & -- & -- & -- & -- & -- & -- & -- & -- & -- & -- & -- & -- & 1,800 & -- & 1,800 & 360 \\
\hline GBPS283436 & -- & -- & -- & -- & -- & -- & -- & -- & -- & -- & -- & -- & -- & -- & -- & 2,000 & -- & -- \\
\hline GBPS290103 & -- & -- & -- & -- & -- & -- & -- & -- & -- & -- & -- & -- & -- & -- & -- & 1,800 & -- & -- \\
\hline GBPS291416 & -- & -- & -- & -- & -- & -- & -- & -- & -- & -- & -- & -- & -- & -- & -- & 1,900 & -- & -- \\
\hline GBP025c & -- & -- & -- & -- & -- & -- & -- & -- & -- & -- & -- & -- & -- & -- & -- & $48 \mu \mathrm{g} / \mathrm{l}^{\mathrm{c}}$ & -- & $9.5 \mu \mathrm{g} / \mathrm{l}^{\mathrm{c}}$ \\
\hline GBP028c & -- & -- & -- & -- & -- & -- & -- & -- & -- & -- & -- & -- & -- & -- & -- & $48 \mu \mathrm{g} / \mathrm{l}^{\mathrm{C}}$ & -- & -- \\
\hline GBP030' & -- & -- & -- & -- & -- & -- & -- & -- & -- & -- & -- & -- & -- & -- & -- & $47 \mu \mathrm{g} / \mathrm{l}^{\mathrm{c}}$ & -- & -- \\
\hline
\end{tabular}

aValue shown in the table is the result reported by the laboratory.

bSample is field duplicate of above sample.

'Sample is a field or source blank (see Table C.4-2) and is a water sample.

-- = Data for this constituent was not rejected. 


\section{C.6.0 Discussion of Investigation Results for the Surface Ground Zero Area}

This section provides a summary of the geophysical and soil sampling findings of the preliminary field investigation in the SGZ area, and offers assumptions as to how the data can be interpreted. Conclusions presented in this portion of the document are meant only to provide direction for further investigation and not to draw final conclusions on the nature and extent of contamination.

The EM31 was used for an initial geophysical survey of the SGZ area. The EM31 data indicated numerous anomalies in both the quadrature phase and the inphase (Figure C.6-1 and Figure C.6-2). Additional data was collected using EM61 in Areas 1, 2, and 3, as indicated in Figure C.6-1 and Figure C.6-2. Data was also collected using GPR at the locations specified as Targets 1 through 8 on Figure C.6-1 and Figure C.6-2. Many of the targets identified could be recognized as specific site features based on historical site photos and plans. Many of these features were further investigated through soil boring and soil sampling (Figure C.6-3).

A summary of the SGZ area features identified during the investigation is provided in Table C.6-1.

\section{C.6.1 Mud Pits}

The geophysical survey was able to locate and roughly delineate the mud pits, approximately where historical documentation indicated they would be (Figure C.6-1). As indicated in Table C.6-1, several of the mud pits indicated in historical photos or assumed to exist were not found as distinct anomalies. It is assumed this is because these mud pits overlap others or did not alter the shallow subsurface enough to create a distinct geophysical anomaly. Further investigation of these mud pits (i.e., Well GB-E Mud Pits B and C, and Well GB-3 Mud Pit) will be covered by the investigation of known mud pits. 


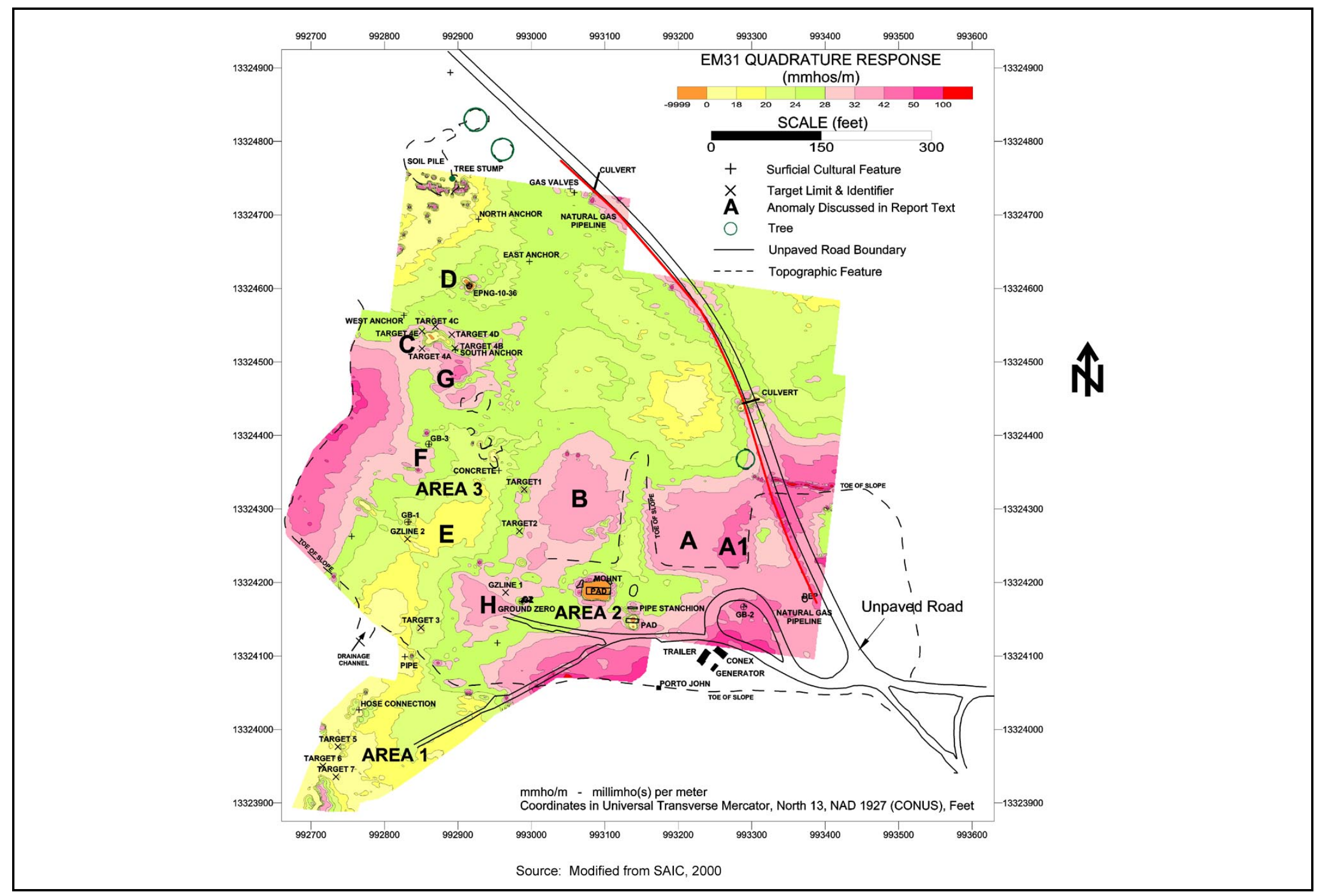

Figure C.6-1

Location of Anomalies Identified by EM31 Survey Quadrature Phase Response at Surface Ground Zero 


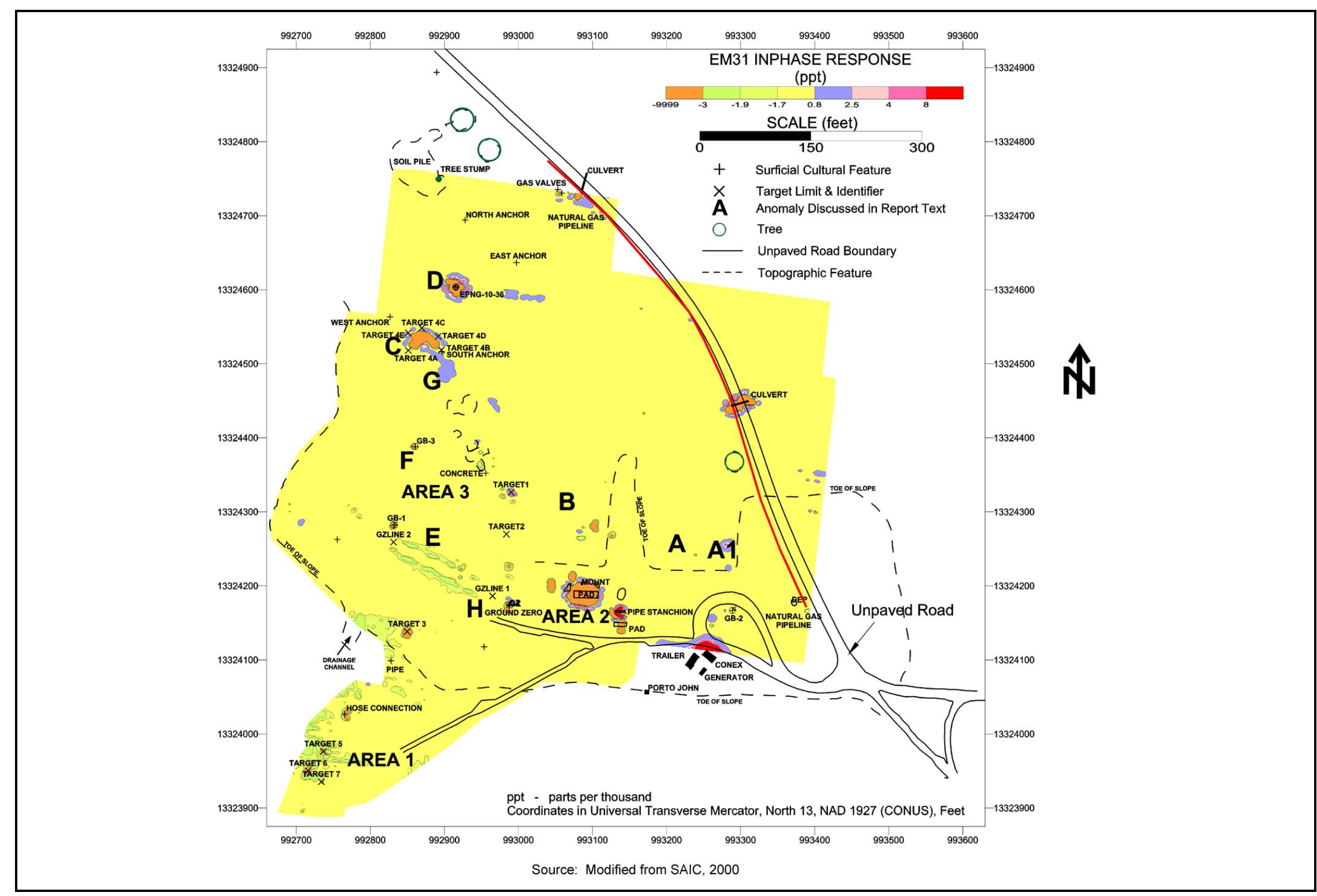

Figure C.6-2

Location of Anomalies Identified by EM31 Survey Inphase Response at Surface Ground Zero 


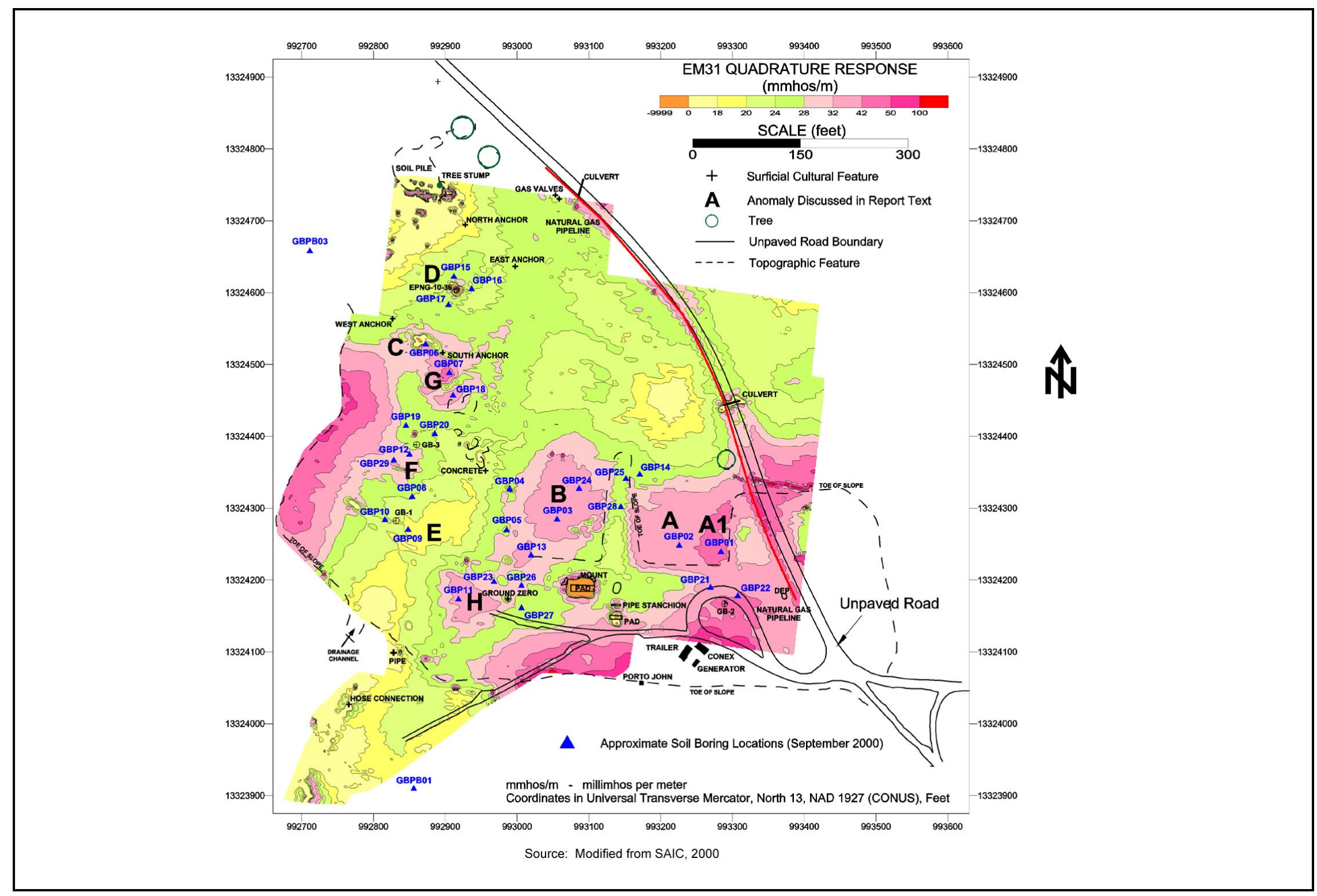

Figure C.6-3

Direct-Push Borehole Locations at Surface Ground Zero 
Table C.6-1

Known and Suspect Site Features

(Page 1 of 5 )

\begin{tabular}{|c|c|c|c|c|c|}
\hline $\begin{array}{l}\text { Unique } \\
\text { Identifier }\end{array}$ & How Feature was Identified ${ }^{a}$ & $\begin{array}{c}\text { Summary of Geophysical } \\
\text { Results }\end{array}$ & $\begin{array}{c}\text { Summary of Borehole } \\
\text { Observations }\end{array}$ & $\begin{array}{c}\text { Summary of Analytical } \\
\text { Results }^{\mathrm{b}}\end{array}$ & Discussion \\
\hline $\begin{array}{l}\text { Well EPNG } \\
10-36 \text { Sump }\end{array}$ & $\begin{array}{c}\text { Historical photos (Figure 2-2) } \\
\text { Geophysics - Anomaly C } \\
\text { (Figure C.6-1 and Figure C.6-2) }\end{array}$ & $\begin{array}{c}\text { EM31 data indicated an } \\
\text { anomaly in area where } \\
\text { sump is expected. EM61 } \\
\text { data indicate buried metal in } \\
\text { area. }\end{array}$ & $\begin{array}{l}\text { One borehole (GBP06) drilled in } \\
\text { approximate center of GP anomaly. } \\
\text { No mud was evident in boring. }\end{array}$ & $\begin{array}{l}\text { Diesel detected at levels } \\
<100 \mathrm{mg} / \mathrm{kg} .\end{array}$ & $\begin{array}{l}\text { Further investigation } \\
\text { planned to define nature } \\
\text { and extent of potential } \\
\text { contamination. }\end{array}$ \\
\hline $\begin{array}{l}\text { Well GB-1 } \\
\text { Mud Pit }\end{array}$ & $\begin{array}{l}\text { Historical plans (Figure 2-3) } \\
\text { Geophysics - Anomaly F } \\
\text { (Figure C.6-1) }\end{array}$ & $\begin{array}{l}\text { EM31 data indicated an } \\
\text { anomaly where mud pit is } \\
\text { expected. Site drawings } \\
\text { indicate mud pit should be } \\
\text { centered approximately } 100 \\
\mathrm{ft} \text { NE of center of anomaly. }\end{array}$ & $\begin{array}{l}\text { One borehole (GBP12) drilled where } \\
\text { center of mud pit indicated by site } \\
\text { drawing. One borehole (GBP29) } \\
\text { drilled in center of GP anomaly. } \\
\text { Evidence of mud observed in both } \\
\text { boreholes within } 4 \mathrm{ft} \text { bgs. }\end{array}$ & $\begin{array}{c}\text { No COPCs detected above } \\
\text { PALs. }\end{array}$ & \multirow{3}{*}{$\begin{array}{l}\text { Based on the results of the } \\
\text { GP survey, it is likely these } \\
\text { mud pits overlap or are not } \\
\text { significant enough to give } \\
\text { a distinct GP profile. For } \\
\text { the purposes of further } \\
\text { investigation, these mud } \\
\text { pits will be characterized } \\
\text { together. Further } \\
\text { investigation is planned to } \\
\text { define extent of this mud } \\
\text { pit(s). }\end{array}$} \\
\hline $\begin{array}{l}\text { Well GB-E } \\
\text { Mud Pit B }\end{array}$ & \multirow{2}{*}{ Historical photos (Figure 2-4) } & \multirow{2}{*}{$\begin{array}{l}\text { Not specifically identified by } \\
\text { GP. }\end{array}$} & \multirow{2}{*}{$\begin{array}{l}\text { No boreholes specifically drilled for } \\
\text { this feature. }\end{array}$} & \multirow{2}{*}{ No samples collected. } & \\
\hline $\begin{array}{l}\text { Well GB-E } \\
\text { Mud Pit C }\end{array}$ & & & & & \\
\hline $\begin{array}{l}\text { Well GB-2 } \\
\text { Mud Pit }\end{array}$ & $\begin{array}{l}\text { Historical plans (Figure 2-3) } \\
\text { Geophysics - Anomaly A } \\
\text { (Figure C.6-1) } \\
\text { Current site features (berms) }\end{array}$ & $\begin{array}{l}\text { EM31 data indicate } \\
\text { anomaly where mud pit } \\
\text { expected. }\end{array}$ & $\begin{array}{c}\text { One borehole (GBP02) drilled in } \\
\text { approximate center of GP anomaly. } \\
\text { Second borehole (GBP01) also } \\
\text { intersected mud pit. Evidence of mud } \\
\text { observed in both borings at } \\
\text { approximately } 9-10 \mathrm{ft} \text { bgs. Mud also } \\
\text { observed at 6-9 ft in GBP01, believed } \\
\text { to be layer associated with Well GB-E } \\
\text { Mud Pit D. }\end{array}$ & $\begin{array}{c}\text { Diesel detected at } \\
\text { approximately } 300 \mathrm{mg} / \mathrm{kg} \text { in } \\
\text { both samples collected within } \\
\text { mud layer associated with Well } \\
\text { GB-2 Mud Pit. }\end{array}$ & $\begin{array}{c}\text { Further investigation } \\
\text { planned to define extent of } \\
\text { mud pit. }\end{array}$ \\
\hline $\begin{array}{l}\text { Well GB-E } \\
\text { Mud Pit A }\end{array}$ & $\begin{array}{l}\text { Historical photos (Figure 2-4) } \\
\text { Geophysics - Anomaly B } \\
\text { (Figure C.6-1) } \\
\text { Current site features (berms) }\end{array}$ & $\begin{array}{c}\text { EM31 data indicate an } \\
\text { anomaly in the area where } \\
\text { mud pit expected. }\end{array}$ & $\begin{array}{l}\text { Two boreholes (GBP03 and GBP24) } \\
\text { drilled in anomaly. Evidence of mud } \\
\text { observed in both borings less than } \\
6 \mathrm{ft} \text { bgs. Third borehole (GBP13) did } \\
\text { not intersect mud pit. }\end{array}$ & $\begin{array}{l}\text { Diesel detected at } \\
\text { concentrations of } 720 \text { and } \\
2,600 \mathrm{mg} / \mathrm{kg} \text { at } 4-6 \mathrm{ft} \text { bgs. }\end{array}$ & $\begin{array}{l}\text { Further investigation } \\
\text { planned to define extent of } \\
\text { mud pit. }\end{array}$ \\
\hline
\end{tabular}


Table C.6-1

\section{Known and Suspect Site Features}

(Page 2 of 5 )

\begin{tabular}{|c|c|c|c|c|c|}
\hline $\begin{array}{l}\text { Unique } \\
\text { Identifier }\end{array}$ & How Feature was Identified ${ }^{a}$ & $\begin{array}{c}\text { Summary of Geophysical } \\
\text { Results }\end{array}$ & $\begin{array}{c}\text { Summary of Borehole } \\
\text { Observations }\end{array}$ & $\begin{array}{c}\text { Summary of Analytical } \\
\text { Results }^{\mathbf{b}}\end{array}$ & Discussion \\
\hline $\begin{array}{l}\text { Well GB-E } \\
\text { Mud Pit D }\end{array}$ & $\begin{array}{l}\text { Historical photo (Figure 2-5) } \\
\text { Geophysics - Anomaly A1 } \\
\text { (Figure C.6-1) } \\
\text { Current features (berms) }\end{array}$ & $\begin{array}{l}\text { EM31 data indicate slight } \\
\text { difference in conductivity at } \\
\text { location where mud pit } \\
\text { expected. This mud pit } \\
\text { overlays the location of the } \\
\text { Well GB-2 Mud Pit }\end{array}$ & $\begin{array}{l}\text { One borehole (GBP01) drilled in } \\
\text { approximate center of anomaly. } \\
\text { Evidence of two distinct mud layers } \\
\text { observed at approximately } 8 \mathrm{ft} \text { bgs } \\
\text { and } 10 \mathrm{ft} \text { bgs. The second layer is } \\
\text { likely from the Well GB-2 Mud Pit, as } \\
\text { discussed above. }\end{array}$ & $\begin{array}{c}\text { Highest incidence of arsenic } \\
(7 \mathrm{mg} / \mathrm{kg}) \text { detected in layer of } \\
\text { mud associated with this mud } \\
\text { pit. Diesel detected at } 2,100 \\
\mathrm{mg} / \mathrm{kg} .\end{array}$ & $\begin{array}{l}\text { Further investigation } \\
\text { planned to define extent of } \\
\text { mud pit. }\end{array}$ \\
\hline $\begin{array}{l}\text { Well GB-E } \\
\text { Mud Pit E }\end{array}$ & $\begin{array}{l}\text { Historical photo(Figure 2-6) } \\
\text { Geophysics - Anomaly G } \\
\text { (Figure C.6-1) }\end{array}$ & $\begin{array}{l}\text { EM31 data indicated an } \\
\text { anomaly where mud pit } \\
\text { expected. }\end{array}$ & $\begin{array}{l}\text { Two boreholes (GBP07 and GBP18) } \\
\text { drilled in anomalous area. Evidence } \\
\text { of mud layer observed in GBP018 } \\
\text { only, at approximately } 10 \mathrm{ft} \text { bgs. }\end{array}$ & $\begin{array}{c}\text { No COPCs were detected } \\
\text { above PALs. }\end{array}$ & $\begin{array}{l}\text { Further investigation } \\
\text { planned to define extent of } \\
\text { mud pit. }\end{array}$ \\
\hline $\begin{array}{l}\text { Well GB-3 } \\
\text { Mud Pit }\end{array}$ & $\begin{array}{l}\text { No historical references to this } \\
\text { mud pit were found during the } \\
\text { records search nor did any site } \\
\text { observations indicate a mud pit. }\end{array}$ & Mud pit not detected by GP. & $\begin{array}{c}\text { No boreholes specifically drilled for } \\
\text { this feature. }\end{array}$ & No samples were collected. & $\begin{array}{l}\text { Based on proximity, it is } \\
\text { assumed that either the } \\
\text { Well GB-1 Mud Pit or the } \\
\text { Well GB-E Mud Pit E, was } \\
\text { likely used during the } \\
\text { drilling of Well GB-3. This } \\
\text { mud pit will not be further } \\
\text { investigated. }\end{array}$ \\
\hline Landfill A & \multirow{3}{*}{ Historical diagram (Figure 2-9) } & \multirow{3}{*}{ Landfill not detected by GP. } & \multirow{3}{*}{$\begin{array}{c}\text { No boreholes specifically drilled for } \\
\text { this feature. }\end{array}$} & \multirow{3}{*}{ No samples were collected. } & \multirow{3}{*}{$\begin{array}{l}\text { Further investigation } \\
\text { planned to determine } \\
\text { nature and extent of } \\
\text { potential contamination. }\end{array}$} \\
\hline Landfill C & & & & & \\
\hline Landfill D & & & & & \\
\hline Landfill B & Historical diagram (Figure 2-9) & Landfill not detected by GP. & $\begin{array}{l}\text { No boreholes specifically drilled for } \\
\text { this feature. }\end{array}$ & No samples were collected. & $\begin{array}{l}\text { Landfill contains only } \\
\text { construction debris. No } \\
\text { further investigation } \\
\text { planned. }\end{array}$ \\
\hline Landfill E & $\begin{array}{l}\text { Historical photos (Figure 2-5) } \\
\text { Geophysics - targets } 1 \text { and } 2 \\
\text { (Figure C.6-2) }\end{array}$ & $\begin{array}{c}\text { EM31 data indicate two } \\
\text { small anomalies where } \\
\text { landfill is expected. GP } \\
\text { data indicate buried metal in } \\
\text { area. }\end{array}$ & $\begin{array}{l}\text { Two boreholes (GBP04 and GBP05) } \\
\text { drilled in approximate center of each } \\
\text { anomaly to } 16 \text { and } 20 \mathrm{ft} \text { bgs, } \\
\text { respectively. No evidence of } \\
\text { contamination observed. }\end{array}$ & $\begin{array}{c}\text { No COPCs were detected } \\
\text { above PALs. }\end{array}$ & $\begin{array}{l}\text { No further investigation } \\
\text { planned. }\end{array}$ \\
\hline
\end{tabular}


Table C.6-1

\section{Known and Suspect Site Features}

(Page 3 of 5 )

\begin{tabular}{|c|c|c|c|c|c|}
\hline $\begin{array}{l}\text { Unique } \\
\text { Identifier }\end{array}$ & How Feature was Identified ${ }^{a}$ & $\begin{array}{c}\text { Summary of Geophysical } \\
\text { Results }\end{array}$ & $\begin{array}{l}\text { Summary of Borehole } \\
\text { Observations }\end{array}$ & $\begin{array}{c}\text { Summary of Analytical } \\
\text { Results }^{\mathrm{b}}\end{array}$ & Discussion \\
\hline Septic Tank A & $\begin{array}{l}\text { Historical diagram (Figure 2-8) } \\
\text { Historical photo (Figure 2-4) } \\
\text { Current site features (tree line) }\end{array}$ & $\begin{array}{c}\text { EM31 data indicated } \\
\text { several anomalies in the } \\
\text { general area. These were } \\
\text { further investigated with } \\
\text { EM61 and GPR. GPR } \\
\text { indicated a subsurface } \\
\text { feature that could represent } \\
\text { a septic tank. }\end{array}$ & $\begin{array}{c}\text { An excavation was dug to } \\
\text { approximately } 2.5 \mathrm{ft} \text { bgs in area } \\
\text { where tank was indicated. No } \\
\text { evidence of septic tank was found. } \\
\text { Seven boreholes were drilled to } 4 \mathrm{ft} \\
\text { bgs and one to } 8 \mathrm{ft} \text { bgs. No indication } \\
\text { of septic tank was evident. }\end{array}$ & \multirow[t]{2}{*}{ No samples were collected. } & \multirow[t]{2}{*}{$\begin{array}{c}\text { Further investigation } \\
\text { planned to verify tank has } \\
\text { been closed in accordance } \\
\text { with NM regulations. }\end{array}$} \\
\hline Septic Tank B & Historical diagram (Figure 2-9) & $\begin{array}{l}\text { Interpretation of GP data } \\
\text { collected by all three } \\
\text { methods does not indicate a } \\
\text { septic tank. }\end{array}$ & $\begin{array}{l}\text { No boreholes specifically drilled for } \\
\text { this feature. }\end{array}$ & & \\
\hline $\begin{array}{l}\text { Well EPNG } \\
\text { 10-36 Drill } \\
\text { Pad }\end{array}$ & $\begin{array}{l}\text { Current site features (wellhead) } \\
\text { Wellhead shows as } \\
\text { geophysics - Anomaly D } \\
\text { (Figure C.6-2) }\end{array}$ & $\begin{array}{l}\text { No anomalies other than } \\
\text { that interpreted as the well } \\
\text { were detected. }\end{array}$ & $\begin{array}{l}\text { Two boreholes (GBP15 and GBP16) } \\
\text { drilled approximately } 20 \mathrm{ft} \text { from well } \\
\text { to } 16 \mathrm{ft} \text { bgs. No evidence of } \\
\text { contamination observed. Third } \\
\text { borehole (GBP17) approximately } \\
25 \mathrm{ft} \text { from center of well advanced to } \\
24 \mathrm{ft} \text { bgs. Possible evidence of } \\
\text { staining observed between } 14 \text { to } 15 \mathrm{ft} \\
\text { bgs. Sample collected at this } \\
\text { interval. }\end{array}$ & $\begin{array}{l}\text { No COPCs were detected } \\
\text { above PALs. }\end{array}$ & $\begin{array}{l}\text { No further investigation } \\
\text { planned. }\end{array}$ \\
\hline $\begin{array}{l}\text { Well GB-1 } \\
\text { Drill Pad }\end{array}$ & $\begin{array}{l}\text { Current site features } \\
\text { (abandoned wellhead) }\end{array}$ & $\begin{array}{l}\text { No anomalies other than } \\
\text { that interpreted as the well } \\
\text { were detected. }\end{array}$ & $\begin{array}{l}\text { Two boreholes (GBP09 and GBP10) } \\
\text { drilled approximately } 20 \mathrm{ft} \text { from well } \\
\text { to } 16 \mathrm{ft} \text { bgs. One borehole (GBP08) } \\
\text { located approximately } 30 \mathrm{ft} \text { from well } \\
\text { also advanced to } 16 \mathrm{ft} \text { bgs. No } \\
\text { evidence of contamination observed } \\
\text { in any of the three boreholes. }\end{array}$ & $\begin{array}{c}\text { No COPCs were detected } \\
\text { above PALs. }\end{array}$ & $\begin{array}{l}\text { No further investigation } \\
\text { planned. }\end{array}$ \\
\hline
\end{tabular}


Table C.6-1

\section{Known and Suspect Site Features}

(Page 4 of 5)

\begin{tabular}{|c|c|c|c|c|c|}
\hline $\begin{array}{l}\text { Unique } \\
\text { Identifier }\end{array}$ & How Feature was Identified ${ }^{a}$ & $\begin{array}{l}\text { Summary of Geophysical } \\
\text { Results }\end{array}$ & $\begin{array}{l}\text { Summary of Borehole } \\
\text { Observations }\end{array}$ & $\begin{array}{c}\text { Summary of Analytical } \\
\text { Results }^{\mathbf{b}}\end{array}$ & Discussion \\
\hline $\begin{array}{l}\text { Well GB-2 } \\
\text { Drill Pad }\end{array}$ & $\begin{array}{l}\text { Current site features } \\
\text { (abandoned wellhead) }\end{array}$ & $\begin{array}{l}\text { No anomalies other than } \\
\text { that interpreted as the well } \\
\text { were detected. }\end{array}$ & $\begin{array}{l}\text { Two boreholes (GBP21 and GBP22) } \\
\text { drilled approximately } 20-25 \mathrm{ft} \text { from } \\
\text { well to depth of } 16 \mathrm{ft} \text { and } 22 \mathrm{ft} \text { bgs, } \\
\text { respectively. Evidence of possible } \\
\text { contamination observed in both holes } \\
\text { from approximately } 0-6 \mathrm{ft} \text { bgs. } \\
\text { Samples collected in this interval. }\end{array}$ & $\begin{array}{l}\text { No COPCs were detected } \\
\text { above PALs. }\end{array}$ & $\begin{array}{l}\text { No further investigation } \\
\text { planned. }\end{array}$ \\
\hline $\begin{array}{l}\text { Well GB-E } \\
\text { Drill Pad }\end{array}$ & $\begin{array}{c}\text { Historical photos (Figure 2-4) } \\
\text { Geophysics - Anomaly H } \\
\text { (Figure C.6-1) } \\
\text { Current site features (SGZ marker) }\end{array}$ & $\begin{array}{l}\text { EM31 data indicate an } \\
\text { anomaly to the south and } \\
\text { west of Well GB-E. This is } \\
\text { likely a compacted pad } \\
\text { used to stabilize the ground } \\
\text { for the drill rig. }\end{array}$ & $\begin{array}{l}\text { One borehole (GBP11) drilled in } \\
\text { approximate center of anomaly } \\
\text { (approximately } 90 \mathrm{ft} \text { west of Well } \\
\text { GB-E) to } 16 \mathrm{ft} \text { bgs. Two additional } \\
\text { boreholes (GBP26 and GBP27) } \\
\text { drilled approximately } 20 \mathrm{ft} \text { from Well } \\
\text { GB-E to } 16 \mathrm{ft} \text { bgs. No evidence of } \\
\text { contamination observed in any of the } \\
\text { three holes. }\end{array}$ & $\begin{array}{c}\text { No COPCs were detected } \\
\text { above PALs. }\end{array}$ & $\begin{array}{l}\text { No further investigation } \\
\text { planned. }\end{array}$ \\
\hline $\begin{array}{l}\text { Well GB-3 } \\
\text { Drill Pad }\end{array}$ & $\begin{array}{l}\text { Current site features } \\
\text { (abandoned wellhead) }\end{array}$ & $\begin{array}{l}\text { No anomalies other than } \\
\text { that interpreted as the well } \\
\text { were detected. }\end{array}$ & $\begin{array}{l}\text { Two boreholes (GBP19 and GBP20) } \\
\text { drilled approximately } 20 \mathrm{ft} \text { from well } \\
\text { to } 16 \mathrm{ft} \text { bgs. No evidence of } \\
\text { contamination observed. }\end{array}$ & $\begin{array}{c}\text { No COPCs were detected } \\
\text { above PALs. }\end{array}$ & $\begin{array}{l}\text { No further investigation } \\
\text { planned. }\end{array}$ \\
\hline $\begin{array}{l}\text { SGZ Cable } \\
\text { Trench }\end{array}$ & $\begin{array}{c}\text { Historical site photos (Figure 2-6) } \\
\text { Geophysics- Anomaly E } \\
\text { (Figure C.6-2) }\end{array}$ & $\begin{array}{c}\text { EM31 data indicates a } \\
\text { linear anomaly trending } \\
\text { northwest from Well GB-E. } \\
\text { Anomaly is likely remnants } \\
\text { of the cable trench visible in } \\
\text { historical photographs. }\end{array}$ & $\begin{array}{l}\text { No boreholes were specifically drilled } \\
\text { for this feature. }\end{array}$ & No samples were collected. & $\begin{array}{l}\text { No further investigation } \\
\text { planned. }\end{array}$ \\
\hline Water line & $\begin{array}{c}\text { Historical photos } \\
\text { (location of water tank) } \\
\text { Geophysics } \\
\text { (EM61 data not shown) } \\
\text { Current site features } \\
\text { (surface depression and hose bib } \\
\text { visible on surface) }\end{array}$ & $\begin{array}{l}\text { EM31 and EM61 data } \\
\text { indicate a linear anomaly } \\
\text { trending north from the } \\
\text { southwest corner of the site. } \\
\text { Based on site drawings and } \\
\text { photographs this is likely a } \\
\text { historical water line. }\end{array}$ & $\begin{array}{l}\text { No boreholes were specifically drilled } \\
\text { for this feature. }\end{array}$ & No samples were collected. & $\begin{array}{c}\text { No further investigation is } \\
\text { planned. }\end{array}$ \\
\hline
\end{tabular}


Table C.6-1

\section{Known and Suspect Site Features}

(Page 5 of 5 )

\begin{tabular}{|c|c|c|c|c|c|}
\hline $\begin{array}{l}\text { Unique } \\
\text { Identifier }\end{array}$ & How Feature was Identified ${ }^{a}$ & $\begin{array}{c}\text { Summary of Geophysical } \\
\text { Results }\end{array}$ & $\begin{array}{c}\text { Summary of Borehole } \\
\text { Observations }\end{array}$ & $\begin{array}{c}\text { Summary of Analytical } \\
\text { Results }^{\mathrm{b}}\end{array}$ & Discussion \\
\hline $\begin{array}{l}\text { Gas flaring } \\
\text { system }\end{array}$ & $\begin{array}{l}\text { Historical photos (Figure 2-7) } \\
\text { Historical diagram (Figure A.4-2) } \\
\quad \text { and documentation } \\
\text { Current site features (berm) }\end{array}$ & NA & $\begin{array}{l}\text { One borehole drilled at the historical } \\
\text { location of the flarestack (GBP25). } \\
\text { Two others were drilled in the vicinity } \\
\text { of the flare stack (GBP14 and } \\
\text { GBP24). Another borehole was } \\
\text { drilled at the location of the gas/water } \\
\text { separator (GBP23). Profile sets } \\
\text { collected for tritium analysis in these } \\
\text { boreholes. }\end{array}$ & $\begin{array}{l}\text { Highest concentration of tritium } \\
\text { (7.32 pCi/g) detected in sample } \\
\text { collected from borehole just } \\
\text { east of flare stack location } \\
\text { (GBP14). The VOC } \\
(1,2,4-\text { Trimethylbezene) was } \\
\text { detected above the PAL at } \\
\text { sample collected } 5-7 \mathrm{ft} \text { bgs in } \\
\text { borehole at former flare stack } \\
\text { location. Diesel and gasoline } \\
\text { were detected above } \\
100 \mathrm{mg} / \mathrm{kg} \text { in same sample. }\end{array}$ & $\begin{array}{l}\text { VOC contaminants } \\
\text { detected are likely from } \\
\text { production and flaring of } \\
\text { petroleum hydrocarbons. } \\
\text { Contamination is assumed } \\
\text { to be localized to the } \\
\text { specific location of the flare } \\
\text { stack. Further investigation } \\
\text { is planned to define the } \\
\text { extent of the } \\
\text { contamination. }\end{array}$ \\
\hline $\begin{array}{l}\text { Berm that } \\
\text { separates } \\
\text { Well GB-2 } \\
\text { Mud Pit and } \\
\text { Well GB-E } \\
\text { Mud Pit A }\end{array}$ & Current site features & NA & $\begin{array}{l}\text { One borehole (GBP28) drilled } \\
\text { through berm approximately midway } \\
\text { along the length. Borehole drilled to } \\
\text { total depth of } 36 \mathrm{ft} \text { bgs. No } \\
\text { groundwater was observed. }\end{array}$ & $\begin{array}{c}\text { Diesel and gasoline were } \\
\text { detected above } 100 \mathrm{mg} / \mathrm{kg} \text {. }\end{array}$ & $\begin{array}{c}\text { Berm is assumed to be } \\
\text { contaminated from Well } \\
\text { GB-E Mud Pit A and Well } \\
\text { GB-2 Mud Pit and will be } \\
\text { further investigated along } \\
\text { with these mud pits and } \\
\text { the flare stack area } \\
\text { investigation. }\end{array}$ \\
\hline
\end{tabular}

${ }^{a}$ Anomalies identified by geophysics are listed by the unique identifiers assigned to them in the report of the results of the geophysical survey (SAIC, 2000).

${ }^{b} \mathrm{COPCs}$ not specifically discussed unless detected above the associated PAL. Arsenic hits above PALs not specifically called out. For the purposes of this table, $100 \mathrm{mg} / \mathrm{kg}$ will be assumed to be the PAL for TPH.

\section{$\mathrm{NE}=$ Northeast}

$\mathrm{GP}=$ Geophysics

NM = State of New Mexico 
A minimum of one borehole was drilled within each identified mud pit. Samples were generally collected within the mud layer, if identifiable; $4 \mathrm{ft}$ below this layer; and again $10 \mathrm{ft}$ below the mud layer. Samples within the mud layer generally indicated levels of TPH diesel above $100 \mathrm{mg} / \mathrm{kg}$. Gasoline was not detected in samples collected within the mud pits. In all cases, except in borehole GBP01, where two distinct layers of mud are evident, the samples collected below the mud layer did not indicate diesel above $100 \mathrm{mg} / \mathrm{kg}$. Thus, it appears that contamination is not migrating. No other COPCs were identified above PALs in mud pits except arsenic. The values of arsenic detected in samples from mud layers or other intervals are not significantly different from those detected in background samples. The highest concentration of arsenic detected, $7 \mathrm{mg} / \mathrm{kg}$, was from a sample collected in the mud layer associated of Well GB-E Mud Pit D. Samples collected at 2 and $3 \mathrm{ft}$ below this sample had levels of arsenic of 1.7 and $2.1 \mathrm{mg} / \mathrm{kg}$, respectively (below the PAL of $2.7 \mathrm{mg} / \mathrm{kg}$ ). Further sampling is needed in this mud pit to ensure a representative value for arsenic is obtained. Further sampling is planned to more accurately define the nature and extent of potential contamination in the mud pits.

\section{Landfills}

The following sections discuss the results of the investigation with regard to the various types of landfills expected to be encountered.

\section{Landfills $A, C$, and $D$ (Mud Landfills)}

These landfills were not identified by the geophysical survey; therefore, no boreholes were drilled in these features during the preliminary field investigation. Their general location is known through historical documentation and further investigations including sampling and analysis are planned.

\section{Landfill B}

The geophysical survey did not identify this landfill. The contents and location of this landfill are known through historical documentation as indicated in Section 2.2.1 of the Work Plan. Since no hazardous constituents are indicated, no further investigation of this feature is planned. 


\section{Landfill E}

The EM31 and EM61 geophysical surveys indicate several anomalies in the general vicinity of where Landfill E was indicated in historical photos. Additional surveys with GPR identified numerous possible metal targets scattered throughout the suspected area. Boreholes GBP04 and GBP05 were drilled in the center of the two "highest" EM31 anomalies. Visual observation of the soil cores did not indicate any evidence of a landfill. Analytical results did not indicate any COPCs above PALs. It is believed this landfill contains metal and other construction debris. No further investigation of this feature is planned.

\section{C.6.2 Septic Tanks}

Geophysics surveys were unable to definitively locate either Septic Tank A (in the southwest portion of the site) or Septic Tank B (near Well GB-E). All three geophysical methods were employed. The EM31and EM61 both indicated several anomalies in the southwest portion of the site that were further investigated with GPR. The results of the GPR investigation indicated one likely target. One borehole was drilled to $8 \mathrm{ft}$ bgs in the center of this target and seven boreholes were drilled to $4 \mathrm{ft}$ bgs within a $3 \mathrm{ft}$ radius of this target. Visual observation of the soil cores did not indicate any evidence of a septic tank.

No likely targets were identified by any of the three geophysical methods in the area where Septic Tank B is indicated by historical documentation. Further investigation of the septic tanks is planned.

\section{C.6.3 Other Anomalies}

Several other distinct anomalies which did not represent known features (e.g., wellhead, road, or culvert pipe) were identified by geophysical methods. A linear anomaly extending roughly from Well GB-E approximately $250 \mathrm{ft}$ to the northwest was identified. Based on interpretation of historical photos, this feature is likely a trench used to run cables from Well GB-E during the experiment (see Figure 2-6). No further investigation of this feature is planned.

A second linear anomaly was identified entering the southwest corner of the site. The anomaly extends approximately $50 \mathrm{ft}$ to the north-northwest, then abruptly turns and extends approximately $250 \mathrm{ft}$ to the northeast. Evidence of this linear anomaly can be seen on the site surface extending an 
additional $240 \mathrm{ft}$, where it ends near the southeast corner of the large concrete pad east of Well GB-E. It is believed that both the geophysical anomaly and the surface depression represent a water line. The water storage tank used during the experiment was located on the hill to the southwest of the site. The path cleared through the trees to construct the water line is still visible. Portions of this water line likely remain in place. No further investigation of this feature is planned.

Numerous small anomalies were identified in the northwest corner of the site near a soil pile. It is possible these anomalies represent small pieces of concrete at or near the surface. The origin of the soil pile is not known. It is not visible in historical photographs taken prior to the original closure (covering) of the Well GB-E mud pits in November-December, 1967 (Figure 2-4). The pile appears to be visible in photographs taken on the day of the detonation (Wofford, 2000b). Further investigation of this soil pile is planned. 


\section{C.7.0 Quality Assurance}

The results of the QA/QC activities for the Gasbuggy preliminary field investigation sampling events are summarized in the following text. Detailed information regarding the QA program is contained in the NM QAPP (Appendix B).

Quality control results are typically judged in terms of precision, accuracy, representativeness, completeness, and comparability and are described in the following sections.

\section{C.7.1 Precision}

Precision is a quantitative measure of the variability of a group of measurements from their average value. Precision is assessed for inorganic analysis by collecting and analyzing duplicate field samples and comparing the results with the original sample. Precision is also assessed by creating, preparing, analyzing, and comparing laboratory duplicates from one or more field samples in inorganic analyses and MS/MSD samples for organic analyses. Precision is reported as RPD, which is calculated as the difference between the measured concentrations of duplicate samples, divided by the average of the two concentrations, and multiplied by 100. Any deviation from these requirements has been documented, explained, and the related data qualified accordingly.

\section{C.7.2 Accuracy}

Analytical accuracy is defined as the nearness of a measurement to the true or accepted reference value. It is the composite of the random and systematic components of the measurement system and measures bias in the measurement system. The random component of accuracy is measured and documented through the analyses of spiked samples. Sampling accuracy is assessed by evaluating the results of spiked samples and laboratory control samples. Accuracy measurements are calculated as percent recovery by dividing the measured sample concentration by the true concentration and multiplying the quotient by 100 .

Field accuracy is assessed by confirming that the documents of record track the sample from its origin, through transfer of custody, to disposal. The goal of field accuracy is for all samples to be collected from the correct locations at the correct time, placed in a correctly labeled container with the 
correct preservative, and sealed with custody tape to prevent tampering. All samples in this sampling event were properly collected and forwarded to the laboratories as described above.

\section{C.7.3 Representativeness}

Representativeness expresses the degree to which sample data accurately and precisely represent a characteristic of a population, parameter variations at a sampling point, or an environmental condition (EPA, 1987). Sample representativeness was achieved through the implementation of a sampling program designed to ensure proper sampling locations, number of samples, and the use of validated analytical methods. Representativeness was assessed through analysis of duplicate samples. Representativeness of the samples taken in this sampling event was assured by collecting the specified number of samples and by analyzing them by the approved analytical methods shown in the NM QAPP (Appendix B).

\section{C.7.4 Completeness}

Completeness is defined as a percentage of measurements made that are judged to be valid. A sampling and analytical requirement of 80 percent completeness was established and achieved for this project. This criteria was taken from the "EPA Guidance for Quality Assurance Project Plans" (EPA, 1998).

The specified sampling locations were utilized as planned. All samples were collected as planned. All sample containers reached the laboratory intact and properly preserved (when applicable). Sample temperatures were maintained during shipment to the laboratory and sample chain of custody was maintained during sample storage and/or shipment.

\section{C.7.5 Comparability}

Comparability is a qualitative parameter expressing the confidence with which one data set can be compared to another (EPA, 1987). To ensure comparability, sampling activities were performed and documented in accordance with approved procedures, and all samples were collected in accordance with the NM QAPP (Appendix B). Approved standardized methods and procedures were also used to analyze and report the data (e.g., CLP and/or CLP-like data packages). This approach ensures that 
the data from this project can be compared to other data sets. Based on the minimum comparability requirements specified in the NM QAPP (Appendix B), all requirements were met.

Field (i.e., sample handling) documentation, laboratory nonconformance reports, and the precision and accuracy of quality-control sample results were evaluated for their effect on the results of the associated environmental sediment samples. The environmental sample results were then qualified according to processes outlined in the following sections. Documentation of the data qualifications resulting from these reviews is retained in project files as both hard copy and electronic media.

\section{C.7.6 Tier I and Tier II Data Evaluations}

All laboratory data from samples collected during the Gasbuggy preliminary field investigation have been evaluated for data quality according to the EPA Functional Guidelines (EPA, 1994b and 1999b). These guidelines are implemented in a tiered process and are presented in the following text. No data rejected during the data evaluation process were used to draw the conclusions. Only valid data, whether estimated (i.e., J-qualified) or not, were used.

The adjustments to data and data qualifiers resulting from the data evaluation process were documented in the project files and were summarized in memoranda for each sample delivery group. These memoranda are maintained in the project files.

\section{C.7.6.1 Tier I Evaluation}

Tier I evaluation for both chemical and radiological analysis examines (but is not limited to):

- Sample count/type consistent with chain of custody

- Analysis count/type consistent with chain of custody

- Correct sample matrix

- Significant problems stated in cover letter or case narrative

- Completeness of certificates of analysis

- Completeness of CLP or CLP-like packages

- Completeness of signatures, dates, and times on chain of custody

- Condition-upon-receipt variance form included

- Requested analyses performed on all samples

- Date received/analyzed given for each sample

- Correct concentration units indicated

- Electronic data transfer supplied 
- Results reported for field and laboratory QC samples

- Whether or not the deliverable met the overall objectives of the project

\section{C.7.6.2 Tier II Evaluation}

Tier II evaluation for both chemical and radiological analysis examines (but is not limited to):

\section{Chemical:}

- Sample date, preparation date, and analysis date for each sample

- Holding time criteria met

- QC batch association for each sample

- Cooler temperature upon receipt

- Sample $\mathrm{pH}$ for aqueous samples, as required

- Detection limits properly adjusted for dilution, as required

- Blank contamination evaluated and applied to sample results/qualifiers

- $\quad$ MS/MSD percent recoveries (\%R) and RPDs evaluated and applied to laboratory results/qualifiers

- Field duplicate RPDs evaluated using professional judgement and applied to laboratory results/qualifiers

- Laboratory duplicate RPDs evaluated and applied to laboratory results/qualifiers

- Surrogate $\% \mathrm{R}$ evaluated and applied to laboratory results/qualifiers

- Laboratory control sample \%R evaluated and applied to laboratory results/qualifiers

- Initial and continuing calibration evaluated and applied to laboratory results/qualifiers

- Internal standard evaluated and applied to laboratory results/qualifiers

- Recalculation of 10 percent of laboratory results from raw data

- Mass spectrometer tuning criteria

- Initial and continuing calibration verification

- Internal standard evaluation

- Organic compound quantification

- Inductively coupled plasma (ICP) interference check sample evaluation

- Graphite furnace atomic absorption quality control

- ICP serial dilution effects 


\section{Radioanalytical:}

- Blank contamination evaluated and validation data qualifier applied to sample results

- Certificate of Analysis consistent with data package documentation

- Quality control sample results (e.g., duplicates, laboratory control samples, MS/MSD) evaluated and validation data qualifiers applied to sample results

- Sample results, error, and minimum detectable activity evaluated and applied to laboratory result qualifiers

- Detector system calibrated to NIST-traceable sources

- Calibration sources preparation was documented, demonstrating proper preparation and appropriateness for sample matrix, emission energies, and concentrations

- Detector system response to daily, weekly, and monthly background and calibration checks for peak energy, peak centroid, peak full-width half-maximum, and peak efficiency

- Tracers NIST-traceable, appropriate for the analysis performed, and recoveries that met QC requirements

- Documentation of all QC sample preparation complete and properly performed

- Spectra lines, emissions, particle energies, peak areas, and background peak areas support the identified radionuclide and its concentration

\section{C.7.6.3 Tier III Evaluation}

Data quality considerations that are included in EPA data review functional guidelines (EPA, 1994b and 1999b) as a Tier III review include the additional evaluations:

\section{Chemical:}

- Recalculation of all laboratory results from raw data

\section{Radioanalytical:}

- QC sample results (e.g., calibration source concentration, percent recovery, and RPD) verified

- Radionuclides and their concentration appropriate considering their decay schemes, half-lives, and process knowledge and history of the facility and site

- Each identified line in spectra verified against emission libraries and calibration results

- Independent identification of spectra lines, area under the peaks, and quantification of radionuclide concentration in a random number of sample results

Tier III review of at least five percent of the sample analytical data is planned. 


\section{C.7.7 Field Quality Control Samples}

There were 23 trip blanks, 4 field blanks, 2 equipment rinsate blanks, 3 source blanks, 4 field duplicates, and 4 MS/MSD collected and submitted for off-site laboratory analysis as shown in Table C.4-2. In addition, 19 laboratory duplicates were analyzed. The samples and duplicates were assigned individual sample numbers and sent to the laboratory "blind." The field blanks were taken by placing deionized water into appropriate sample bottles at the sampling location and preserving them according to the requirements specified in the NM QAPP (Appendix B). The equipment rinsate blank was obtained by collecting deionized water, which was poured over the decontaminated sampling equipment, into the appropriate sample bottles, and preserved as applicable. The field duplicates were taken at the same location as the environmental sample and MS/MSD. The trip blanks, which were received preserved and sealed from the laboratory, were placed in each shipping cooler containing samples for VOC analysis. The source blank for the rinsate water was obtained by collecting rinsate source water (Farmington municipal source) directly from the container used to store the water on site, into the appropriate sample bottles and preserved as applicable. The two source blanks for the Lexan ${ }^{\mathrm{TM}}$ tubes (liners for the sample collection core barrel) were collected in the same fashion as the equipment rinsate blank. The MS/MSD samples were collected as duplicate volumes of environmental samples. The results of the QC samples are discussed in the following sections.

\section{C.7.7.1 Field Blank Analysis}

Review of the field-collected blank analytical data for the Gasbuggy preliminary field investigation indicates that contamination from field methods may have occurred during sample collection. Samples were analyzed for the parameters listed in Table C.4-2. Acetone and chloroform were detected in several equipment rinsate and field blanks at concentrations that exceeded the Contract-Required Detection Limit (CRDL). Acetone was also detected in trip blank sample 25400547 at a concentration that was at the CRDL. An overall review of the data indicated that field and shipping cross-contamination may have occurred. Although concentrations were above the CRDL, the PALs were not exceeded and the results did not have an impact on the investigation. 


\section{C.7.7.2 Field Duplicate Analysis}

During the sampling event, four field duplicate samples were sent as blind samples to the laboratory to be analyzed for the investigation parameters listed in Table C.4-2. For these samples, the precision of duplicate sample results (i.e., RPDs between the environmental sample results and their corresponding field duplicate sample results) were evaluated to the guidelines set forth in EPA Functional Guidelines (EPA, 1994b and 1999b). The EPA Functional Guidelines state that there are no required review criteria for field duplicate analyses comparability, but allow the data reviewer to exercise professional judgement in qualifying data based upon the results of the field duplicates. The RPD between the environmental samples results and their corresponding field duplicates exceeded the 20 percent criteria for water and the 35 percent for soil (EPA, 1994b).

\section{C.7.7.3 Matrix Spike Analysis}

A total of four field samples were selected for use as MS/MSD samples. The percent recoveries of these samples (a measure of accuracy) and the relative percent differences in these sample results (a measure of precision) were compared to EPA Functional Guidelines criteria (EPA, 1994b and 1999b). The results were used to qualify associated environmental sample results accordingly.

The EPA Functional Guidelines for review of organic data state that no data qualification action is taken on the basis of MS/MSD results alone. As allowed by EPA functional guidelines, the data reviewer exercises professional judgement in considering these results in conjunction with the results of laboratory control samples (LCSs) and other QC criteria in applying qualifications to the data.

Generally, if the spike recovery is greater than the upper acceptance limits ( $>125$ percent), nondetections are acceptable for use. If the spike recovery is greater than the upper acceptance limits ( $>125$ percent) or less than the lower acceptance limits ( $<75$ percent), positive results are qualified as estimated (J). If spike recovery is within the range of 30-74 percent, nondetections are qualified as estimated (UJ). If spike recovery is less than 30 percent (grossly low), positive results are not qualified and nondetections were qualified as unusable (R). 


\section{C.7.8 Laboratory Quality Control Samples}

Analysis of QC method blanks, LCSs, and surrogate spikes for organic analyses (and method blanks, preparation blanks, initial and continuing calibration blanks, and LCSs for metals) were performed for each sample delivery group by Paragon Analytics, Inc. The results of these analyses were used to qualify associated environmental sample results according to EPA Functional Guidelines (EPA, 1994b and 1999b).

The EPA Functional Guidelines (EPA, 1994b and 1999b) state that no qualification action is taken if a compound is found in a sample, but not in the associated blank. The action taken when a compound is detected in both the sample and the associated blank varies depending upon the analyte involved, and is described in the "The $5 \mathrm{X} / 10 \mathrm{X}$ Rule."

For most VOCs, SVOCs, TPH (i.e., DRO and GRO), and radionuclides, if an analyte is detected in the sample and is also detected in an associated blank, the result is qualified as undetected (U), if the sample concentration is less than five times (5X) the blank concentration. However, for the common laboratory contaminants (e.g., methylene chloride, acetone, 2-butanone [methyl ethyl ketone], and phthalate esters [especially bis(2-ethylhexyl)phthalate]), the factor is raised to ten times (10X) the blank concentration. The sample result is elevated to the quantitation limit if it is less than the quantitation limit, or remains unaltered if the sample result is greater than or equal to the quantitation limit.

For inorganics (i.e., metals), sample results greater than the instrument detection limit, but less than five times (5X) the amount found in an associated blank, are qualified as undetected (U). There are no metallic common laboratory contaminants, so there is no "10X Rule" for metals, and the sample result is never altered. When applying the $5 \mathrm{X}$ criteria to soil sample data or calibration blank data, the raw data results are used to evaluate and qualify the reported results on the Certificate of Analysis. Preparation blanks (PB) are evaluated for each matrix, with every sample delivery group, or with each batch of samples digested, whichever is more frequent. The analyte concentration in the PB should be below the CRDL. If any analyte concentration in the PB is above the CRDL, the lowest concentration of that analyte in the associated samples must be ten times (10X) the PB concentration. Otherwise, all samples associated with the PB with the analyte's concentration less than 10X the PB 
concentration, and above the CRDL, should be redigested and reanalyzed. If the concentration of the PB is less than or equal to the CRDL, no corrective action to the associated sample is required.

\section{C.7.8.1 Laboratory Surrogate Spikes}

Surrogate spikes (e.g., system monitoring compounds) are added to the environmental samples analyzed by chromatographic techniques for VOCs, SVOCs, TPH (i.e., DRO and GRO). Surrogate compounds are analytes that are not expected to be present in associated environmental samples, but behave the same as similar target compounds chromatographically. Known amounts of each surrogate are added prior to sample preparation and are carried throughout the preparation and analysis procedures. The percent recoveries of these surrogate compounds give some measure of the anticipated recoveries of the target compounds whose chromatographic behavior they mimic.

If any surrogate percent recoveries are out of the acceptable range (which differs for each surrogate in each method), laboratory protocol requires the sample to be reprepared and/or reanalyzed. When the surrogate recoveries are acceptable on the second run, only the second analysis results are reported. When both analyses yield the same unacceptable range, the results of both analyses are reported.

The evaluation of surrogate spike percent recovery results is not straightforward. The functional guidelines suggest several optional approaches, but require the data reviewer to exercise professional judgement in reviewing surrogate data and qualifying associated data as estimated ( $\mathrm{J}$ or UJ for detections or nondetections, respectively) or unusable (R).

\section{C.7.8.2 Laboratory Duplicate Analysis}

The laboratory duplicate samples were compared to the criteria set forth in the EPA Functional Guidelines (EPA, 1994b and 1999b), and the associated sample results were qualified accordingly. Both detections and nondetections have been qualified as estimated ( $\mathrm{J}$ and $\mathrm{UJ}$, respectively), if the relative percent difference between an environmental sample and its laboratory duplicate fell outside established criteria.

One laboratory duplicate analysis for metals was performed for each sample delivery group and sample matrix that reported metals. The duplicate results were compared to the results of the original sample to give a measure of analytical laboratory precision. If the results from a duplicate analysis 
for a particular analyte fall outside the control limits, the EPA Functional Guidelines for Inorganic Data Review (EPA, 1994b) call for all results for that analyte in all associated samples of the same matrix to be qualified as estimated (J).

Laboratory control samples, also known as blank spikes, consist of known quantities of target compounds added to purified sand or deionized, deionized water prepared and analyzed along with the environmental samples in the sample delivery group. The percent recoveries of the compounds in the LCS give a measure of laboratory accuracy. The functional guidelines call for the data reviewer to use professional judgement to qualify associated data according to established criteria.

\section{C.7.9 Field Nonconformances}

During the Gasbuggy preliminary field investigation, the DOE contractor QA representatives provided field guidance and oversight to verify that sampling activities were performed in accordance with applicable requirements. Quality assurance representatives did not observe findings, deficiencies, or nonconformances with sampling activities. There were no nonconformances found during data review and validation.

\section{C.7.10 Laboratory Nonconformances}

Laboratory nonconformances are generally due to inconsistencies in analytical instrumentation operation, sample preparations, extractions, and fluctuations in internal standard and calibration results. Several nonconformances were documented for this project. These nonconformances have been accounted for in the data qualification process. Documentation of these results is retained in the project files Gasbuggy preliminary field investigation. 


\section{C.8.0 Summary}

Analysis of data and observations from the surface and shallow subsurface preliminary field investigation conducted at the Gasbuggy Site indicate the following:

- The report on the results of the biological survey concluded that "no affect will occur to any USFW threatened, endangered, proposed candidate, or species of concern as a result of environmental studies taking place at the Gasbuggy Site. No affect will occur to State of New Mexico threatened, endangered, or species of concern or USFS Sensitive Species as a result of environmental studies at the Gasbuggy Site" (TRC, 2000a).

- The cultural resources survey identified one site on the south side of the road through the CP that could potentially impact future investigations. The report on the survey findings concluded that cultural resource monitoring is recommended should any future ground-disturbing work occur south of the road (TRC, 2000b). Although the documented boundaries of the "site" overlap the CP boundaries, no ground-disturbing work is planned within the specified "site" boundaries at the current time.

- Geophysical surveys in the Well GB-D area identified two anomalies that will be further investigated. One is believed to be the mud pit used during drilling of Well GB-D. The second anomaly is believed to be associated with a nearby soil pile, and may be representative of an excavation and fill event. Further investigation at the Well GB-D area will be based on this information.

- Geophysical surveys at the RTP identified one anomaly that will be further investigated. This anomaly is believed to be associated with a nearby soil pile, and may be representative of an excavation and fill event. Further investigation at the RTP will be based on this information.

- Geophysical surveys at the CP identified several anomalies believed to be associated with the septic system located at this site. Further investigation will be conducted to determine if the septic tank was closed (filled) in accordance with State of New Mexico regulations.

Geophysical surveys also identified an anomaly near the historic location of the mobile radiological trailer. This anomaly will be further investigated by sampling and analysis.

- Geophysical surveys in the SGZ area identified and defined most of the predicted mud pits. Those not identified by geophysics are believed either to have not existed (e.g., no mud pit was specifically constructed during the drilling of Well GB-3, but instead existing mud pits such as Well GB-E Mud Pit E, were used) or the mud pits were not significant enough to produce an identifiable EM signature. Geophysical data will be used, where applicable, to delineate the lateral extent of the mud pits. 
- Samples collected from observed mud layers within several of the mud pits indicated potential diesel contamination. Further sampling and analysis is planned to further refine the nature and extent of contamination in the mud pits.

- Geophysical surveys in the SGZ area did not identify the Landfills (A, C, and D) used to dispose of the drilling fluids generated during the abandonment of site wells in 1978. These landfills were not sampled during the preliminary field investigation. Sampling and analysis to define the nature and extent of potential contamination within these landfills is planned.

- Geophysical surveys in the SGZ area did not identify Landfill B used to dispose of concrete and asphalt pads. No further investigation of this landfill is proposed.

- Geophysical surveys identified two small anomalous areas where Landfill E was predicted. Samples from boreholes in these areas did not detect and COPCs above PALs. No further investigation of this landfill is proposed.

- Geophysical surveys in the SGZ area did not definitively define or eliminate from consideration the septic tanks indicated by historical documentation to be located in this area. Further investigation will be conducted to determine if the septic tanks were closed (filled) in accordance with State of New Mexico regulations.

- Concentrations of TPH were detected above $100 \mathrm{mg} / \mathrm{kg}$ in seven samples. Five of these seven samples were collected from a layer of drilling mud identified by visual observation within the mud pits. TPH diesel was detected above $100 \mathrm{mg} / \mathrm{kg}$ in all of these samples. Gasoline was not detected above $100 \mathrm{mg} / \mathrm{kg}$ in these samples. The remaining two of seven were collected from the berm that separates the Well GB-2 Mud Pit from Well GB-E Mud Pit A. One of these from the northern end of the berm at the historic location of the flare stack. Each of these two samples had detections of TPH, both in the diesel and gasoline range, over $100 \mathrm{mg} / \mathrm{kg}$. In all cases where TPH was detected at levels greater than $100 \mathrm{mg} / \mathrm{kg}$, a sample collected at a lower depth in the same borehole indicated a TPH concentration of less than $100 \mathrm{mg} / \mathrm{kg}$ and/or a nondetect. The diesel contamination will be further investigated as part of the investigations of the mud pits. The gasoline contamination will be further investigated as part of the flare stack area investigation.

- The only VOC detected above PALs was 1,2,4-Trimethylbenzene. This contaminant was detected at the 5 to $7 \mathrm{ft}$ bgs interval in a borehole drilled at the historic location of the flare stack. The contamination is believed to be localized to this location. The source of the contamination is not known but believed to be associated with production and flaring of natural petroleum hydrocarbons. Further investigation will be conducted in the flare stack area to determine the nature and extent of this potential contamination.

- $\quad$ No SVOCs were detected at levels which exceeded PALs. 
- Arsenic was the only metal detected above PALs. Based on statistical analysis, arsenic levels in background and site characterization samples appear to be not significantly different from each other. Additional site characterization and background samples will be collected.

- Tritium levels, detected in samples collected from locations where the highest levels of tritium were detected in 1978, indicate a range of less than the minimum detectable concentration to $7.32 \mathrm{pCi} / \mathrm{g}$ of tritium. Based on the preliminary dose/risk assessment provided in Appendix D, these levels do not pose a risk to human health.

- The COPCs requested to be analyzed for by NM OCD were compared against Region IX PRGs, if applicable. None of these COPCs exceeded its corresponding PRG. Further analysis of the data was not done at this time. This data may be used in the corrective action decision document to support decisions made on the closure of the mud pits.

- Analysis of samples by TCLP did not detect any COPCs which exceeded RCRA regulatory limits (CFR, 1999).

- Rejected data did not impact the characterization.

- Groundwater was not found in the areas investigated. The maximum depth of investigation was $36 \mathrm{ft}$ bgs. The deepest contamination detected was at 9 to $11 \mathrm{ft}$ bgs. 


\section{C.9.0 References}

CFR, see Code of Federal Regulations.

Code of Federal Regulations. 1999. Title 40, Part 261, "Identification and Listing of Hazardous Waste." Washington, DC: U.S. Government Printing Office.

EPA, see U.S. Environmental Protection Agency.

Merck and Co., Inc. 1976. The Merck Index, Ninth Edition. Rahway, NJ.

Merck, see Merck and Co., Inc.

NMAC, see New Mexico Administrative Code.

New Mexico Administrative Code. 1996a. Title 20 NMAC 6.2, Ground and Surface Water Protection. Santa Fe, NM.

New Mexico Administrative Code. 1996b. Title 19 NMAC 15 Part C, 105, Pit for Clay, Shale, Drill Fluid and Drill Cuttings. Santa Fe, NM.

SAIC, see Science Application International Corporation.

Science Application International Corporation. 2000. Third Quarter 2000 Surface Geophysical Survey Report Gasbuggy Site Dulce, New Mexico. Prepared by J. Warren. Harrisburg, PA.

TRC. 2000a. Biological Assessment and Evaluation Gasbuggy Site Carson National Forest Rio Arriba County, New Mexico. Prepared by N.J. Kasting. Albuquerque, NM.

TRC. 2000b. Cultural Resources Survey of Four Operational Areas for the Gasbuggy Site Carson National Forest Rio Arriba County, New Mexico, 1993-02-64C. Prepared by J.C. Acklen. Albuquerque, NM.

U.S. Department of Energy, Nevada Operations Office. 1993a. A Class III Cultural Resources Survey of the U.S. Department of Energy Gasbuggy Stimulation Test Site, Rio Arriba County, New Mexico, DOE/NV/10972--66. Prepared by IT Corporation and Mariah Associates. Las Vegas, NV.

U.S. Department of Energy, Nevada Operations Office. 1993b. Sensitive Species Survey Results for the Gasbuggy and Gnome-Coach Sites, New Mexico, DOE/NV/10972--54. Prepared by IT Corporation. Las Vegas, NV. 
U.S. Environmental Protection Agency. 1987. Data Quality Objectives for Remedial Response Activities, EPA/540/G-87-003. Washington, DC.

U.S. Environmental Protection Agency. 1994a. Guidance for the Data Quality Objective Process, EPA QA/G-4, September. Washington, DC.

U.S. Environmental Protection Agency. 1994b. USEPA Contract Laboratory Program National Functional Guidelines for Inorganic Data Review, EPA-540/R-94/013. Washington, DC.

U.S. Environmental Protection Agency. 1998. EPA Guidance for Quality Assurance Project Plans, EPA/600/R-98/018. Washington, DC.

U.S. Environmental Protection Agency. 1999c. Region IX Preliminary Remediation Goals (PRGs) 1999. Prepared by S.J. Smucker. San Franciso, CA.

U.S. Environmental Protection Agency. 1999b. USEPA Contract Laboratory Program National Functional Guidelines for Organic Data Review, EPA 540/R-99/008. Washington, DC.

Wofford, S., Lawrence Livermore National Laboratory. 2000. Letter to J. Simms (IT Corporation) transmitting 16 photographs of the Gasbuggy Site, 7 March. Copies of photographs are available in the ITLV Technical Information Center. Livermore, CA: Laboratory Archives. 
Appendix D

Gasbuggy Site Surface Radiological Dose/Risk Assessment 


\section{D.1.0 Introduction}

This appendix addresses the overall baseline human health effects of exposure to radionuclides of potential concern in surface soil, shallow subsurface soil, air, and shallow groundwater at the Gasbuggy Site. This assessment focuses on the potential dose to a human receptor for three potentially exposed populations. The objective of this assessment was to determine the need for additional data on tritium concentrations in the surface and shallow subsurface soil. Based on the findings of this assessment no further samples for tritium in surface and shallow subsurface soil at the Gasbuggy Site need to be collected.

The human health dose assessment was performed to estimate the potential risk which may occur at the Gasbuggy Site under normal operating conditions. This dose assessment was performed using the RESRAD computer code, Version 5.95 (ANL, 1993b and 1999). The use of the maximum contaminant concentration and/or other maximum parameter values in this appendix is not meant to set precedent. Use of maximum values is not in accordance with the guidance given in DOE Order 5400.5 or the guidance given in the guides for implementing RESRAD (ANL, 1993a and b). Maximum parameter values were used to simplify the modeling process. Using the more conservative parameter values, resulted in an estimated risk from radiological contaminants at the Gasbuggy Site below acceptable action levels (CFR, 1999). 


\section{D.2.0 Identification of Radionuclides of Potential Concern}

The historical radiological survey and sampling results for the surface and shallow subsurface soil at the Gasbuggy Site are summarized in Appendix A. Based on the information and conclusions presented in Appendix A, tritium is the only radionuclide of potential concern for the surface/shallow subsurface at the Gasbuggy Site.

Tritium samples were collected at the Gasbuggy Site during the preliminary field investigation in August and September 2000. The results of the sampling are summarized in Appendix C. The maximum detected tritium activity found during the preliminary field investigation was $7.32 \mathrm{pCi} / \mathrm{g}$ at a depth of 7 to $8 \mathrm{ft}$ bgs. This activity was used throughout this assessment. 


\section{D.3.0 Human Health Dose Assessment}

This human health assessment was performed in accordance with applicable state and federal guidance.

\section{D.3.1 Exposure Assessment}

This section identifies exposure pathways and quantifies radionuclide exposure. The purpose of this exposure assessment is to estimate the type and magnitude of exposure to humans.

\section{D.3.1.1 Exposure Pathways}

For exposure and potential risks to occur, complete exposure pathways must exist. A complete pathway requires the following elements (EPA, 1989):

- A source and mechanism for release of contamination

- A transport or retention medium

- A point of potential human contact (exposure point)

- An exposure route at the exposure point

If any one of these elements is missing, the pathway is not considered complete. Following is a brief discussion of the exposure pathway elements.

For the purposes of this assessment, the contamination source is assumed to be the flaring of contaminated gas and water vapor that took place as part of the Gasbuggy Project. The transport/retention mediums of concern for this assessment are surface and shallow subsurface soil.

Exposure points are locations of human contact with contaminated media. Exposure points consider human activity patterns and the location of potentially exposed individuals relative to the location of contaminated media. The Gasbuggy Site is surrounded by national forest and the primary land use for Gasbuggy is recreational or open space. However, there is cattle grazing in the vicinity of Gasbuggy and the potential for on-site ranching does exist. In addition, the Jicarilla Apache reservation is also adjacent to the Gasbuggy Site. Therefore, there is also the potential for Native American recreational land use at the site, including the potential for on-site hunting. On-site recreational hunting is assumed to be similar to a Native American hunter, therefore, the doses are 
similar. Only the Native American hunter will be presented in this assessment. To maintain the conservative methodology, the contact point for soil, both surface and shallow subsurface, contamination in all exposure scenarios is located at the contaminant source (i.e., direct contact is assumed). It is assumed the Native American will not reside at the site.

The following exposure routes were examined:

- Ingestion

- Inhalation

- Dermal absorption

- External exposure (tritium is a beta emitter; therefore, the dose due to external exposure is negligible)

- Ingestion of on-site cattle (rancher scenario only)

- Ingestion of on-site deer (native American scenario only)

The potentially complete exposure pathways include exposure to surface soil, shallow subsurface soil (under limited conditions), air, and groundwater (as modeled by RESRAD). Table D.3-1 lists the complete human exposure pathways for current and future land use. This table also indicates which pathways have been selected for risk characterization, and presents the rationale for inclusion or exclusion of each pathway. 
Table D.3-1

Potentially Complete Human Exposure Pathways at Gasbuggy

(Page 1 of 2)

\begin{tabular}{|c|c|c|c|c|}
\hline $\begin{array}{l}\text { Environmental } \\
\text { Medium }\end{array}$ & Exposure Route & $\begin{array}{l}\text { Potentially Exposed } \\
\text { Population }\end{array}$ & $\begin{array}{l}\text { Pathway Selected } \\
\text { for Evaluation }\end{array}$ & Reason for Selection or Exclusion \\
\hline Surface Soil & $\begin{array}{l}\text { Inhalation } \\
\text { Ingestion } \\
\text { Dermal Absorption } \\
\text { External Exposure }^{a}\end{array}$ & $\begin{array}{l}\text { Residential } \\
\text { Occupational }\end{array}$ & No & $\begin{array}{l}\text { Gasbuggy is surrounded by national forest land and the } \\
\text { land use is expected to remain similar in the future. }\end{array}$ \\
\hline Surface Soil & $\begin{array}{l}\text { Inhalation } \\
\text { Ingestion } \\
\text { Dermal Absorption } \\
\text { External Exposure }^{\mathrm{a}}\end{array}$ & $\begin{array}{l}\text { Recreational } \\
\text { Rancher } \\
\text { Native American }\end{array}$ & Yes & $\begin{array}{l}\text { Potential intermittent recreational exposure is likely under } \\
\text { current and future conditions. Ranching is known to occur } \\
\text { in the general vicinity of the Gasbuggy Site. }\end{array}$ \\
\hline $\begin{array}{l}\text { Shallow } \\
\text { Subsurface Soil }\end{array}$ & $\begin{array}{l}\text { Inhalation } \\
\text { Ingestion } \\
\text { Dermal Absorption } \\
\text { External Exposure }^{\mathrm{a}}\end{array}$ & $\begin{array}{l}\text { Residential } \\
\text { Occupational }\end{array}$ & No & $\begin{array}{l}\text { Gasbuggy is surrounded by national forest land and the } \\
\text { land use is expected to remain similar in the future. }\end{array}$ \\
\hline $\begin{array}{l}\text { Shallow } \\
\text { Subsurface Soil }\end{array}$ & $\begin{array}{l}\text { Inhalation } \\
\text { Ingestion } \\
\text { Dermal Absorption } \\
\text { External Exposure }^{\mathrm{a}}\end{array}$ & $\begin{array}{l}\text { Recreational } \\
\text { Rancher } \\
\text { Native American }\end{array}$ & Yes & $\begin{array}{l}\text { Potential intermittent exposure is likely under current and } \\
\text { future conditions. Direct contact with shallow subsurface } \\
\text { soil is assumed. }\end{array}$ \\
\hline Soil & Ingestion of Meat & $\begin{array}{l}\text { Residential } \\
\text { Occupational } \\
\text { Recreational }\end{array}$ & No & $\begin{array}{l}\text { Gasbuggy is surrounded by national forest land and the } \\
\text { land use is expected to remain similar in the future. }\end{array}$ \\
\hline Soil & Ingestion of Meat & $\begin{array}{l}\text { Rancher } \\
\text { Native American }\end{array}$ & Yes & $\begin{array}{l}\text { Ranching is known to occur in the general vicinity of the } \\
\text { Gasbuggy Site. It is assumed the ranchers ingest meat } \\
\text { from on-site cattle. For the Native American scenario, } \\
\text { on-site recreation use is assumed, including hunting and } \\
\text { ingestion of on-site deer. }\end{array}$ \\
\hline Surface Water & $\begin{array}{l}\text { Inhalation } \\
\text { Ingestion } \\
\text { External Exposure }\end{array}$ & $\begin{array}{l}\text { Residential } \\
\text { Occupational } \\
\text { Recreational } \\
\text { Rancher } \\
\text { Native American }\end{array}$ & No & $\begin{array}{l}\text { There are no permanent on-site surface water bodies at } \\
\text { Gasbuggy. }\end{array}$ \\
\hline
\end{tabular}


Table D.3-1

Potentially Complete Human Exposure Pathways at Gasbuggy

(Page 2 of 2)

\begin{tabular}{|c|c|c|c|c|}
\hline $\begin{array}{l}\text { Environmental } \\
\text { Medium }\end{array}$ & Exposure Route & $\begin{array}{c}\text { Potentially Exposed } \\
\text { Population }\end{array}$ & $\begin{array}{l}\text { Pathway Selected } \\
\text { for Evaluation }\end{array}$ & Reason for Selection or Exclusion \\
\hline $\begin{array}{c}\text { Shallow } \\
\text { Groundwater }\end{array}$ & $\begin{array}{l}\text { Inhalation } \\
\text { Ingestion } \\
\text { Dermal Absorption } \\
\text { External Exposure }^{a}\end{array}$ & $\begin{array}{l}\text { Residential } \\
\text { Occupational }\end{array}$ & No & $\begin{array}{l}\text { Gasbuggy is surrounded by national forest land. The } \\
\text { established institutional controls and land use is expected } \\
\text { to remain similar in the future. }\end{array}$ \\
\hline $\begin{array}{l}\text { Shallow } \\
\text { Groundwater }\end{array}$ & $\begin{array}{l}\text { Inhalation } \\
\text { Ingestion } \\
\text { Dermal Absorption } \\
\text { External Exposure }^{a}\end{array}$ & $\begin{array}{l}\text { Recreational } \\
\text { Rancher } \\
\text { Native American }\end{array}$ & Yes & $\begin{array}{l}\text { Potential intermittent recreational exposure is likely under } \\
\text { current and future conditions. Ranching is known to occur } \\
\text { in the general vicinity of the Gasbuggy Site. Groundwater } \\
\text { doses were based on modeled tritium concentrations from } \\
\text { soil. Depth to shallow groundwater was not encountered } \\
\text { during the preliminary field investigation. During the } \\
\text { investigation, boreholes were routinely drilled to } 20 \mathrm{ft} \text { bgs } \\
\text { and a maximum of } 36 \mathrm{ft} \text { bgs. Depth to shallow } \\
\text { groundwater was assumed to be approximately } 30 \mathrm{ft} \text { bgs }\end{array}$ \\
\hline
\end{tabular}

${ }^{\text {aT }}$ Tritium is a beta emitter; therefore, the dose due to external exposure is negligible.

Note: For the recreational, rancher, and Native American scenarios, it was assumed that food and water consumed on site will be brought in by the respective individuals. 
Since land use at Gasbuggy is expected to remain similar, future pathways will be similar to the current pathways listed above. Therefore, this risk assessment assumes that restrictions currently in place (see Section 2.1.1 of the Work Plan) will remain for the foreseeable future.

Under these conditions, the current and future human health risks are identical (i.e., the pathways and receptors are the same). For the remainder of the document, these risks/doses will be linked to the same receptors with no further consideration of whether the exposure is current or future.

\section{D.3.1.2 Quantification of Exposure}

This section describes the estimation of exposure for tritium that may come into contact with human receptors. The process involves the following:

- Identification of applicable human exposure models (i.e., RESRAD) and input parameters

- Determination of the concentration of each contaminant in environmental media at the point of human exposure

- Estimation of human doses

For each potentially complete exposure pathway identified in Section D.3.1.1, a reasonable maximum exposure (RME) scenario has been developed. The RME is the highest exposure that is reasonably expected to occur at a site (EPA, 1989). The intent of the RME, as defined by EPA, is to estimate a conservative exposure case (i.e., well above the average case) that is still within the possible range of exposures. The RME is both protective and reasonable but is not the worst possible case (EPA, 1991b).

\section{D.3.1.3 Exposure Models}

RESRAD is a computer code developed at Argonne National Laboratory for DOE to calculate site-specific residual radioactive material guidelines as well as radiation dose and excess lifetime cancer risk to a chronically exposed on-site receptor (ANL, 1993b). A soil release guideline is defined as the radionuclide concentration in soil that is acceptable if the site is to be used without radiological restrictions. Soil is defined as unconsolidated earth material, including rubble and debris that might be present. These guidelines are based on the following principles: (1) the annual radiation dose received by a member of the critical population group from the residual radioactive 
material (i.e., predicted by a realistic but reasonably conservative analysis and calculated as committed effective dose equivalent [CEDE]) should not exceed 25 millirem per year (mrem/yr), and (2) doses should be kept as-low-as-reasonable-achievable (ALARA).

RESRAD uses a pathway analysis method in which the relation between radionuclide concentrations in soil and the dose to a member of a critical population group is expressed as a pathway sum, which is the sum of products of "pathway factors". Pathway factors correspond to pathway segments connecting compartments in the environment between which radionuclides can be transported or radiation emitted. Radiation doses, health risks, soil guidelines, and media concentrations are calculated over user-specified time intervals. The source is adjusted over time to account for radioactive decay and ingrowth, leaching, erosion, and mixing. For tritium, the transport coefficient used was 1.0. In addition, RESRAD includes an estimate for dermal contact of tritium within the internal radiation exposure pathway. RESRAD results are presented as CEDE.

\section{D.3.1.4 Exposure Parameters}

Three types of parameters are used in exposure models to estimate potential dose:

- Radionuclide-related parameters (e.g., exposure-point concentrations, dose conversion factors)

- $\quad$ Site-specific parameters (e.g., wind speed, precipitation)

- Parameters that describe the exposed population (e.g., contact rate, exposure frequency, and duration)

The exposed population and exposure-related parameters are summarized in Table D.3-2. The exposure parameters were taken from available site information, EPA guidance, and best professional judgement using site-specific information, where available. Upper-bound values are generally $90^{\text {th }}$ or $95^{\text {th }}$ percentile values, depending on the data available for each parameter. Because of the preliminary nature of this dose calculation, the more conservative $90^{\text {th }}$ or $95^{\text {th }}$ percentile value is used instead of the mean, which is more appropriate for a RME dose calculation. If no site-specific information was available, the RESRAD default was used as a reasonable upper bound estimate (ANL, 1993a). A combination of upper-bound and average exposure parameters were used to estimate the RME for each scenario. 
Table D.3-2

RESRAD Parameters for Gasbuggy

(Page 1 of 6)

\begin{tabular}{|c|c|c|c|c|}
\hline Parameters & $\begin{array}{l}\text { Recreational } \\
\text { Scenario }\end{array}$ & $\begin{array}{l}\text { Native } \\
\text { American } \\
\text { Scenario }\end{array}$ & $\begin{array}{l}\text { Rancher } \\
\text { Scenario }\end{array}$ & Source of Parameter Data \\
\hline $\begin{array}{l}\text { Area of contaminated zone } \\
\qquad\left(\mathrm{m}^{2}\right)\end{array}$ & 32,000 & 32,000 & 32,000 & $\begin{array}{l}\text { Total site area - approximately } \\
8 \text { acres } \\
\text { (estimate based on aerial } \\
\text { photo, see Figure } 2-1 \text { ) }\end{array}$ \\
\hline $\begin{array}{l}\text { Initial input concentration for } \\
\text { tritium }(\mathrm{pCi} / \mathrm{g})\end{array}$ & $7.32^{\mathrm{a}}$ & $7.32^{\mathrm{a}}$ & $7.32^{\mathrm{a}}$ & $\begin{array}{l}\text { Maximum measured } \\
\text { radionuclide concentrations } \\
\text { (see Appendix } \mathrm{C} \text { ) }\end{array}$ \\
\hline $\begin{array}{l}\text { Thickness of contaminated } \\
\text { zone }(\mathrm{m})\end{array}$ & 0.3048 & 0.3048 & 0.3048 & Assumes one foot ${ }^{b}$ \\
\hline $\begin{array}{l}\text { Length parallel to aquifer } \\
\text { flow }(\mathrm{m})\end{array}$ & 300 & 300 & 300 & $\begin{array}{l}\text { Maximum length of site cross } \\
\text { section parallel to aquifer flow } \\
\text { based on site dimensions } \\
\text { (see Figure } 2-1 \text { ) }\end{array}$ \\
\hline $\begin{array}{l}\text { Basic radiation dose limit } \\
\text { (mrem/yr) }\end{array}$ & 25 & 25 & 25 & See Section D.3.2 \\
\hline $\begin{array}{l}\text { Time since placement of } \\
\text { radioactive material }(\mathrm{yr})\end{array}$ & 0 & 0 & 0 & $\begin{array}{l}\text { Based on current tritium levels } \\
\text { in soil }\end{array}$ \\
\hline Cover depth (m) & 0 & 0 & 0 & $\begin{array}{c}\text { Assumes surface } \\
\text { contamination (conservative } \\
\text { assumption) }\end{array}$ \\
\hline $\begin{array}{l}\text { Density of cover material } \\
\qquad\left(\mathrm{g} / \mathrm{cm}^{3}\right)\end{array}$ & NA & NA & NA & NA \\
\hline $\begin{array}{l}\text { Cover depth erosion rate } \\
\qquad(\mathrm{m} / \mathrm{yr})\end{array}$ & NA & NA & NA & NA \\
\hline $\begin{array}{l}\text { Density of contaminated } \\
\text { zone }\left(\mathrm{g} / \mathrm{cm}^{3}\right)\end{array}$ & 1.5 & 1.5 & 1.5 & RESRAD default \\
\hline $\begin{array}{c}\text { Contaminated zone erosion } \\
\text { rate }(\mathrm{m} / \mathrm{yr})\end{array}$ & 0.001 & 0.001 & 0.001 & RESRAD default \\
\hline $\begin{array}{l}\text { Contaminated zone total } \\
\text { porosity }\end{array}$ & 0.4 & 0.4 & 0.4 & RESRAD default \\
\hline $\begin{array}{l}\text { Contaminated zone effective } \\
\text { porosity }\end{array}$ & 0.2 & 0.2 & 0.2 & RESRAD default \\
\hline $\begin{array}{l}\text { Contaminated zone } \\
\text { hydraulic conductivity (m/yr) }\end{array}$ & 10 & 10 & 10 & RESRAD default \\
\hline $\begin{array}{c}\text { Contaminated Zone B } \\
\text { parameter }\end{array}$ & 5.3 & 5.3 & 5.3 & RESRAD default \\
\hline
\end{tabular}


Table D.3-2

RESRAD Parameters for Gasbuggy (Page 2 of 6)

\begin{tabular}{|c|c|c|c|c|}
\hline Parameters & $\begin{array}{l}\text { Recreational } \\
\text { Scenario }\end{array}$ & $\begin{array}{c}\text { Native } \\
\text { American } \\
\text { Scenario }\end{array}$ & $\begin{array}{l}\text { Rancher } \\
\text { Scenario }\end{array}$ & Source of Parameter Data \\
\hline $\begin{array}{l}\text { Evapotranspiration } \\
\text { coefficients }\end{array}$ & 0.8 & 0.8 & 0.8 & $\begin{array}{c}\text { Conservative value based on } \\
\text { regional data }{ }^{c}\end{array}$ \\
\hline Precipitation (m/yr) & 0.43 & 0.43 & 0.43 & Regional climate center ${ }^{c}$ \\
\hline Irrigation (m/yr) & 0.0 & 0.0 & 0.0 & No on-site irrigation \\
\hline Irrigation mode & Overhead & Overhead & Overhead & RESRAD default \\
\hline Runoff coefficient & 0.2 & 0.2 & 0.2 & RESRAD default \\
\hline $\begin{array}{l}\text { Watershed area from nearby } \\
\text { stream or pond }\left(\mathrm{m}^{2}\right)\end{array}$ & $10^{6}$ & $10^{6}$ & $10^{6}$ & RESRAD default \\
\hline $\begin{array}{l}\text { Accuracy for water/soil } \\
\text { computations }\end{array}$ & 0.001 & 0.001 & 0.001 & RESRAD default \\
\hline $\begin{array}{l}\text { Density of saturated zone } \\
\qquad\left(\mathrm{g} / \mathrm{cm}^{3}\right)\end{array}$ & 1.5 & 1.5 & 1.5 & RESRAD default \\
\hline Saturated zone total porosity & 0.4 & 0.4 & 0.4 & RESRAD default \\
\hline $\begin{array}{l}\text { Saturated zone effective } \\
\text { porosity }\end{array}$ & 0.2 & 0.2 & 0.2 & RESRAD default \\
\hline $\begin{array}{l}\text { Saturated zone hydraulic } \\
\text { conductivity }(\mathrm{m} / \mathrm{yr})\end{array}$ & 100 & 100 & 100 & RESRAD default \\
\hline $\begin{array}{l}\text { Saturated zone hydraulic } \\
\text { gradient }\end{array}$ & 0.02 & 0.02 & 0.02 & RESRAD default \\
\hline Saturated Zone B parameter & 5.3 & 5.3 & 5.3 & RESRAD default \\
\hline Water table drop rate (m/yr) & 0.001 & 0.001 & 0.001 & RESRAD default \\
\hline $\begin{array}{l}\text { Well pump intake depth (m } \\
\text { below water table) }\end{array}$ & 10 & 10 & 10 & RESRAD default \\
\hline $\begin{array}{c}\text { Model: Nondispersion (ND) } \\
\text { or Mass-Balance (MB) }\end{array}$ & ND & ND & ND & RESRAD default \\
\hline Well pumping rate $\left(\mathrm{m}^{3} / \mathrm{yr}\right)$ & Not used & Not used & Not used & NA \\
\hline $\begin{array}{l}\text { Number of Uncontaminated } \\
\text { unsaturated zone strata }\end{array}$ & 1 & 1 & 1 & Assumed value \\
\hline $\begin{array}{l}\text { Unsaturated Zone 1, } \\
\text { thickness }(\mathrm{m})\end{array}$ & 10 & 10 & 10 & $\begin{array}{l}\text { Conservative assumption } \\
\text { based on preliminary field } \\
\text { investigation } \\
\text { (see Appendix C) }\end{array}$ \\
\hline $\begin{array}{l}\text { Unsaturated Zone 1, soil } \\
\text { density }\left(\mathrm{g} / \mathrm{cm}^{3}\right)\end{array}$ & 1.5 & 1.5 & 1.5 & RESRAD default \\
\hline
\end{tabular}


Table D.3-2

RESRAD Parameters for Gasbuggy

(Page 3 of 6)

\begin{tabular}{|c|c|c|c|c|}
\hline Parameters & $\begin{array}{l}\text { Recreational } \\
\text { Scenario }\end{array}$ & $\begin{array}{c}\text { Native } \\
\text { American } \\
\text { Scenario }\end{array}$ & $\begin{array}{l}\text { Rancher } \\
\text { Scenario }\end{array}$ & Source of Parameter Data \\
\hline $\begin{array}{l}\text { Unsaturated Zone 1, total } \\
\text { porosity }\end{array}$ & 0.4 & 0.4 & 0.4 & RESRAD default \\
\hline $\begin{array}{l}\text { Unsaturated Zone 1, } \\
\text { effective porosity }\end{array}$ & 0.2 & 0.2 & 0.2 & RESRAD default \\
\hline $\begin{array}{l}\text { Unsaturated Zone 1, } \\
\text { soil-specific b parameter }\end{array}$ & 5.3 & 5.3 & 5.3 & RESRAD default \\
\hline $\begin{array}{c}\text { Unsaturated Zone } 1, \\
\text { hydraulic conductivity (m/yr) }\end{array}$ & 10 & 10 & 10 & RESRAD default \\
\hline $\begin{array}{l}\text { Exposure Frequency (d/yr) } \\
\text { (not used as input value) }\end{array}$ & 14 & 14 & 30 & Assumed value \\
\hline $\begin{array}{c}\text { Daily inhalation rate }\left(\mathrm{m}^{3} / \mathrm{d}\right) \\
\text { (not used as input value) }\end{array}$ & 20 & 20 & 20 & EPA, 1991a \\
\hline $\begin{array}{l}\text { Annual inhalation rate } \\
\qquad\left(\mathrm{m}^{3} / \mathrm{yr}\right)\end{array}$ & 280 & 280 & 600 & EPA, 1991a \\
\hline $\begin{array}{l}\text { Daily drinking rate }(\mathrm{L} / \mathrm{d}) \\
\text { (not used as input value) }\end{array}$ & 2 & 2 & 2 & EPA, 1991a \\
\hline Annual drinking rate (L/yr) & 28 & 28 & 60 & EPA, 1991a \\
\hline $\begin{array}{l}\text { Mass loading for inhalation } \\
\qquad\left(\mathrm{g} / \mathrm{m}^{3}\right)\end{array}$ & 0.00001 & 0.00001 & 0.00001 & Anspaugh et al., 1974 \\
\hline Exposure duration (yr) & 30 & 30 & 25 & EPA, 1991a \\
\hline Shielding factor, inhalation & 1.0 & 1.0 & 1.0 & No indoor shielding \\
\hline $\begin{array}{l}\text { Shielding factor, external } \\
\text { gamma }\end{array}$ & 1.0 & 1.0 & 1.0 & $\begin{array}{c}\text { Conservative assumption - no } \\
\text { shielding }\end{array}$ \\
\hline $\begin{array}{l}\text { Fraction of time spent } \\
\text { indoors }\end{array}$ & 0.0 & 0.0 & 0.0 & No on-site indoor exposure \\
\hline $\begin{array}{l}\text { Fraction of time spent } \\
\text { outdoors (on site per year) }\end{array}$ & 0.038 & 0.038 & 0.082 & $\begin{array}{l}\text { Based on fraction of time } \\
\text { spent on site }\end{array}$ \\
\hline $\begin{array}{l}\text { Shape factor, external } \\
\text { gamma }\end{array}$ & 1.0 & 1.0 & 1.0 & RESRAD default \\
\hline $\begin{array}{l}\text { Fruits, vegetables, and grain } \\
\text { consumption }(\mathrm{kg} / \mathrm{yr})\end{array}$ & NA & NA & NA & NA \\
\hline $\begin{array}{l}\text { Leafy vegetable } \\
\text { consumption (kg/yr) }\end{array}$ & NA & NA & NA & NA \\
\hline Meat consumption (kg/yr) & NA & 63 & 63 & RESRAD default \\
\hline
\end{tabular}


Table D.3-2

RESRAD Parameters for Gasbuggy

(Page 4 of 6)

\begin{tabular}{|c|c|c|c|c|}
\hline Parameters & $\begin{array}{l}\text { Recreational } \\
\text { Scenario }\end{array}$ & $\begin{array}{c}\text { Native } \\
\text { American } \\
\text { Scenario }\end{array}$ & $\begin{array}{l}\text { Rancher } \\
\text { Scenario }\end{array}$ & Source of Parameter Data \\
\hline Milk consumption (L/yr) & NA & NA & NA & $\begin{array}{l}\text { Milk ingestion not considered; } \\
\text { primarily beef cattle and deer }\end{array}$ \\
\hline Soil ingestion rate $(\mathrm{g} / \mathrm{yr})$ & 1.4 & 1.4 & 3.0 & $\begin{array}{l}\text { Based on } 100 \mathrm{mg} / \mathrm{d} \\
\quad(\mathrm{EPA}, 1991 \mathrm{a})\end{array}$ \\
\hline $\begin{array}{l}\text { Household water fraction } \\
\text { contaminated }\end{array}$ & 1 & 1 & 1 & RESRAD default ${ }^{d}$ \\
\hline $\begin{array}{c}\text { Livestock water fraction } \\
\text { contaminated }\end{array}$ & NA & 1.0 & 1.0 & Conservative assumption \\
\hline Milk consumption (L/yr) & NA & NA & NA & $\begin{array}{l}\text { Milk ingestion not considered; } \\
\text { primarily beef cattle and deer }\end{array}$ \\
\hline $\begin{array}{l}\text { Irrigation water fraction } \\
\text { contaminated }\end{array}$ & NA & 1 & 1 & Site/scenario-specific ${ }^{e}$ \\
\hline $\begin{array}{c}\text { Contaminated fraction of } \\
\text { plants }\end{array}$ & NA & NA & NA & NA \\
\hline $\begin{array}{l}\text { Contaminated fraction of } \\
\text { meat }\end{array}$ & NA & 0.016 & 0.08 & Assumed value \\
\hline $\begin{array}{l}\text { Livestock fodder intake for } \\
\text { meat }(\mathrm{kg} / \mathrm{d})\end{array}$ & NA & $68^{f}$ & 68 & RESRAD default \\
\hline $\begin{array}{l}\text { Livestock water intake for } \\
\text { meat }(\mathrm{l} / \mathrm{d})\end{array}$ & NA & 50 & 50 & RESRAD default \\
\hline $\begin{array}{l}\text { Livestock intake for soil } \\
\qquad(\mathrm{kg} / \mathrm{d})\end{array}$ & NA & 0.5 & 0.5 & RESRAD default \\
\hline $\begin{array}{l}\text { Mass loading for foliar } \\
\text { deposition }\left(\mathrm{g} / \mathrm{m}^{3}\right)\end{array}$ & NA & 0.00001 & 0.00001 & Anspaugh et al., 1974 \\
\hline $\begin{array}{l}\text { Depth of soil mixing layer } \\
\qquad(\mathrm{m})\end{array}$ & 0 & 0 & 0 & RESRAD default \\
\hline Depth of roots $(\mathrm{m})$ & NA & 0.9 & 0.9 & RESRAD default \\
\hline $\begin{array}{l}\text { Household fractional usage } \\
\text { from groundwater }\end{array}$ & NA & NA & NA & NA \\
\hline $\begin{array}{l}\text { Irrigation fractional usage } \\
\text { from groundwater }\end{array}$ & NA & 1 & 1 & Site/scenario-specific ${ }^{e}$ \\
\hline
\end{tabular}


Table D.3-2

RESRAD Parameters for Gasbuggy

(Page 5 of 6)

\begin{tabular}{|c|c|c|c|c|}
\hline Parameters & $\begin{array}{l}\text { Recreational } \\
\text { Scenario }\end{array}$ & $\begin{array}{c}\text { Native } \\
\text { American } \\
\text { Scenario }\end{array}$ & $\begin{array}{l}\text { Rancher } \\
\text { Scenario }\end{array}$ & Source of Parameter Data \\
\hline $\begin{array}{l}\text { Livestock fractional usage } \\
\text { from groundwater }\end{array}$ & NA & 1 & 1 & $\begin{array}{l}\text { Conservative assumption - } \\
\text { fraction of usage from } \\
\text { groundwater is unknown }\end{array}$ \\
\hline \multicolumn{5}{|c|}{ Storage times for contaminated foodstuffs } \\
\hline $\begin{array}{l}\text { Fruits, nonleafy vegetables } \\
\text { and grains (d) }\end{array}$ & NA & NA & NA & NA \\
\hline Leafy vegetables (d) & NA & NA & NA & NA \\
\hline Meat $(d)$ & NA & 20 & 20 & RESRAD default \\
\hline Milk (d) & NA & NA & NA & NA \\
\hline Water well $(d)$ & 1 & 1 & 1 & RESRAD default \\
\hline Water surface $(d)$ & NA & NA & NA & NA \\
\hline Livestock fodder (d) & NA & 45 & 45 & RESRAD default \\
\hline \multicolumn{5}{|c|}{ Thickness of material (m) } \\
\hline In the foundation & NA & NA & NA & NA \\
\hline In contamination zone soil & NA & NA & NA & NA \\
\hline \multicolumn{5}{|c|}{ Density of material $\left(\mathrm{g} / \mathrm{cm}^{3}\right)$} \\
\hline In the foundation & NA & NA & NA & NA \\
\hline In the contaminated soil & NA & NA & NA & NA \\
\hline \multicolumn{5}{|c|}{ Total porosity of material } \\
\hline In the foundation & NA & NA & NA & NA \\
\hline In the contaminated soil & NA & NA & NA & NA \\
\hline \multicolumn{5}{|c|}{ Volumetric water content } \\
\hline In the foundation & NA & NA & NA & NA \\
\hline In the contaminated soil & NA & NA & NA & NA \\
\hline \multicolumn{5}{|c|}{ Diffusion coefficient for radon gas (m/sec) } \\
\hline In the foundation & NA & NA & NA & NA \\
\hline In the contaminated soil & NA & NA & NA & NA \\
\hline $\begin{array}{l}\text { Contamination zone radon } \\
\text { diffusion coefficient }\end{array}$ & NA & NA & NA & NA \\
\hline
\end{tabular}


Table D.3-2

RESRAD Parameters for Gasbuggy

(Page 6 of 6 )

\begin{tabular}{|c|c|c|c|c|}
\hline Parameters & $\begin{array}{l}\text { Recreational } \\
\text { Scenario }\end{array}$ & $\begin{array}{c}\text { Native } \\
\text { American } \\
\text { Scenario }\end{array}$ & $\begin{array}{l}\text { Rancher } \\
\text { Scenario }\end{array}$ & Source of Parameter Data \\
\hline $\begin{array}{l}\text { Radon vertical dimension of } \\
\text { mixing }\end{array}$ & NA & NA & NA & NA \\
\hline $\begin{array}{l}\text { Average annual wind speed } \\
\qquad(\mathrm{m} / \mathrm{sec})\end{array}$ & 2.0 & 2.0 & 2.0 & RESRAD Default \\
\hline $\begin{array}{l}\text { Average building air } \\
\text { exchange rate }(1 / \mathrm{hr})\end{array}$ & NA & NA & NA & NA \\
\hline $\begin{array}{l}\text { Height of the building (room) } \\
\qquad(\mathrm{m})\end{array}$ & NA & NA & NA & NA \\
\hline Building interior area factor & NA & NA & NA & NA \\
\hline $\begin{array}{l}\text { Building depth below ground } \\
\text { surface }(\mathrm{m})\end{array}$ & NA & NA & NA & NA \\
\hline $\begin{array}{c}\text { Emanating power of } \mathrm{Rn}-222 \\
\text { gas }\end{array}$ & NA & NA & NA & NA \\
\hline $\begin{array}{c}\text { Emanating power of } R n-220 \\
\text { gas }\end{array}$ & NA & NA & NA & NA \\
\hline
\end{tabular}

${ }^{\mathrm{a}} \mathrm{A}$ concentration of $7.32 \mathrm{pCi} / \mathrm{g}$ was the highest detection of tritium encountered during the preliminary field investigation (Appendix C). Since this investigation focused on areas where previous sampling indicated the highest levels of tritium and a limited number of samples were collected, a mean value was not calculated; therefore, $7.32 \mathrm{pCi} / \mathrm{g}$ was used as a conservative value.

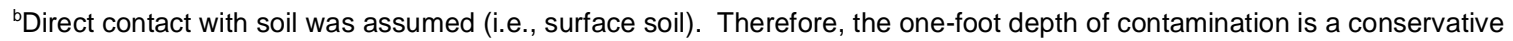
estimation assuming that all of the soil is at the maximum tritium activity of $7.32 \mathrm{pCi} / \mathrm{g}$.

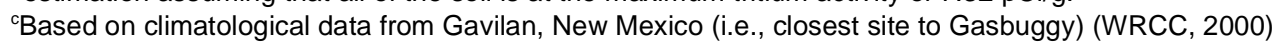

${ }^{\mathrm{d}}$ This parameter value cannot be edited in the application input file.

${ }^{\text {e}}$ Although there is no on-site irrigation, it was conservatively assumed to exist for the Native American and Rancher scenarios to account for the possibility of deer/cattle drinking on-site water (e.g., runoff).

'The deer ingestion rate was assumed to be identical to the cattle ingestion rate due to the lack of site-specific data. This is conservative due to the fact that deer eat considerably less than cattle.

NA $=$ Not applicable

$\mathrm{m}^{2}=$ Square meters

$\mathrm{pCi} / \mathrm{g}=$ Picocuries per gram

$\mathrm{m}=$ Meters

$\mathrm{mrem} / \mathrm{yr}=$ Millirem per year

$\mathrm{yr}=$ Year

$\mathrm{g} / \mathrm{cm}^{3}=$ Grams per cubic centimeter

\author{
$\mathrm{m} / \mathrm{yr}=$ Meters per year \\ $\mathrm{m}^{3} / \mathrm{yr}=$ Square meters per year \\ $\mathrm{d} / \mathrm{yr}=$ Days per year \\ $\mathrm{m}^{3} / \mathrm{d}=$ Cubic meters per day \\ $\mathrm{L} / \mathrm{d}=$ Liters per day \\ $\mathrm{L} / \mathrm{yr}=$ Liters per year \\ $\mathrm{kg} / \mathrm{yr}=$ Kilograms per year
}

$\mathrm{g} / \mathrm{yr}=$ Grams per year $\mathrm{mg} / \mathrm{d}$ Milligrams per day $\mathrm{kg} / \mathrm{d}=$ Kilograms per day $\mathrm{d}=$ Days $\mathrm{m} / \mathrm{sec}=$ Meters per second $\mathrm{L} / \mathrm{hr}=$ Liters per hour 


\section{D.3.2 Dose/Risk Characterization}

This section provides a characterization of the potential doses/risks associated with the exposure to tritium at the Gasbuggy Site. This assessment employs a health-protective bias that leads to the overestimation of potential dose. Individuals are exposed to an RME (see Section D.3.1.1), and exposure is evaluated (see Section D.3.1.2) to provide estimates of annual exposure.

\section{D.3.2.1 Dose/Risk Criteria}

Summarized below are dose criteria guidelines from existing and proposed regulations and guidance. The dose criteria are used in the corrective action level evaluation by determining what level of residual concentrations of contaminants is the soil is acceptable and do not exceed established guidelines. The following is a brief summary of the applicable DOE and Nuclear Regulatory Commission (NRC) regulations. Also included is a discussion of the ALARA analysis as outlined in each of the regulations. The following regulatory dose standards are summarized below:

- DOE Order 5400.5, Radiation Protection of the Public and the Environment (DOE, 1993)

- 10 CFR Part 20, Standards for Protection Against Radiation (CFR, 2000).

\section{DOE Order 5400.5}

The primary dose limits for members of the public from all DOE activities, including remedial actions, are established in Chapters II and IV in DOE Order 5400.5 (DOE, 1993). Chapter II of DOE Order 5400.5 states, "the exposure of members of the public to radiation sources as a consequence of all routine DOE activities shall not cause, in a year, an effective dose equivalent greater then 100 mrem."

The primary dose limit is expressed as a CEDE, a term developed by the International Commission on Radiological Protection (ICRP) for their risk-based system, which requires the risk-weighted summation of doses to various tissues and organs of the body. The basic dose limit (100 mrem) is used in establishing guideline concentrations of residual radioactive material in the soil. This basic dose limit is an annual limit for members of the public who are assumed to participate in worst-case exposure scenarios (residential rancher and farmer). Other exposure scenarios could include an industrial worker and/or a recreational user. This regulation requires an environmental pathway analysis using approved models such as RESRAD to derive acceptable levels of radionuclides in soils 
from all exposure pathways. Radiation dose is assessed for these exposure scenarios every year during a 1,000 year time frame.

Chapter II of DOE Order 5400.5 requires that the ALARA process be adopted in planning, monitoring, cleanup, and control of residual radioactive material (DOE, 1993). DOE Order 5400.5 states "ALARA requires judgement with respect to what is reasonably achievable. Factors that relate to societal, technological, economic, and other policy considerations shall be evaluated to the extent practicable in making such judgements." These factors include:

- The maximum dose to members of the public

- The collective dose to the population

- Alternative processes

- Doses for each alternative processes

- Costs for each technological alternative

- Differential doses from various pathways

The ALARA analysis may be quantitative (i.e., cost-benefit analysis) or qualitative. However, in either case, the bases for judgement should be clearly stated. The ALARA process for DOE Order 5400.5 is summarized in greater detail in the draft document Applying the ALARA Process for Radiation Protection of the Public and Environmental Compliance with 10 CFR Part 834 and DOE 400.5 ALARA Program Requirements - Volumes I and II (DOE, 1997).”

\section{Title 10 CFR Part 20}

The 10 CFR Part 20 regulations (CFR, 2000) establish standards for protection against ionizing radiation resulting from activities conducted under licenses issued by the NRC. Subpart D of 10 CFR Part 20 states that operations should be conducted so "the total effective dose equivalent to individual members of the public from the licensed operation does not exceed 100 mrem in a year, exclusive of the dose contributions from background radiation, any medical administration the individual has received, voluntary participation in medical research programs, and the licensee's disposal of radioactive material into sanitary sewerage." Subpart E further states this criteria for license termination: "a site will be considered acceptable for unrestricted use if the residual radioactivity that is distinguishable from background radiation results in a total effective dose equivalent (TEDE) to an average member of the critical group that does not exceed 25 mrem per year, including that from groundwater sources of drinking water, and the residual radioactivity has been 
reduced to ALARA levels." Subpart E further states that, if the land use was restricted, the $25 \mathrm{mrem} /$ year limit would still apply. Therefore, an unrestricted exposure scenario would still have to be considered. The radiation dose (if the land restrictions fail) shall not exceed $100 \mathrm{mrem} / \mathrm{year}$. Therefore, any individual will not receive more than the ICRP recommended dose limit of $100 \mathrm{mrem} /$ year under any land-use scenarios.

Title 10 CFR Part 20 states that to the extent practicable, procedures and engineering controls based upon sound radiation protection principles shall be used to achieve occupational doses and doses to members of the public that are ALARA.

Based on the available information and regulations, a dose criteria of $25 \mathrm{mrem} / \mathrm{yr}$ is the only promulgated dose criteria and is considered protective to human health. Therefore, $25 \mathrm{mrem} / \mathrm{yr}$ will be used for comparison purposes at the Gasbuggy Site. Note that DOE Order 5400.5 is currently being revised to include the $25 \mathrm{mrem} / \mathrm{yr}$ criteria. It is not known when the revised DOE Order will be issued.

\section{D.3.2.2 Risk Criteria}

The EPA classifies all radionuclides as Group A carcinogens. Ingestion and inhalation slope factors are central estimates in a linear model of the age-averaged, lifetime attributable radiation cancer incidence (fatal and nonfatal cancer) risk per unit of activity inhaled or ingested, expressed as risk/pCi. External exposure slope factors $(\mathrm{SF})$ are central estimates of lifetime attributable radiation cancer incidence risk for each year of exposure to external radiation from photon-emitting radionuclides distributed uniformly in a thick layer of soil and are expressed as risk/yr per pCi/gram soil. When combined with site-specific media concentration data and appropriate exposure assumptions, SFs can be used to estimate lifetime cancer risks to members of the general population due to radionuclide exposures. In most cases, cancer risks are limiting, exceeding both mutagenic and teratogenic risks. The slope factor used in RESRAD Version 5.95 (ANL, 1999) is taken from the EPA Health Effects Assessment Summary Tables (EPA, 1995).

In evaluating the calculated exposure from potentially carcinogenic radionuclides, a reasonable level of risk must be selected. The EPA used an incremental lifetime cancer risk (ILCR) (also referred to as excess cancer risk) of one in one million $\left(1 \times 10^{-6}\right)$ as the lower bound of an acceptable range. The 
upper bound of an acceptable ILCR recommended by the EPA for drinking water is 1 in 10,000 $\left(1 \times 10^{-4}\right)(\mathrm{EPA}, 1999)$. In addition, the EPA specifies a risk range of $10^{-6}$ to $10^{-4}$ associated with the consideration and selection of remedial alternatives for contaminated media in the National Contingency Plan (NCP) (CFR, 1999).

Based on the regulatory precedents cited above, a reasonable and appropriate ILCR range would be from $10^{-6}$ to $10^{-4}$. As implemented under the NCP, pathway risks greater than $10^{-6}$ ILCR must receive risk management consideration (CFR, 1999). This quantitative risk screening is one of many factors that are considered in the decision-making process for the need for additional analytical data. Therefore, there is no single risk value that defines "acceptable" and "unacceptable" risk. The purpose of this risk screening is to present qualitative estimates of potential risk; thus, all sites greater than the cumulative upper bound of $10^{-4}$ will be examined further for the need for additional data.

Cumulative site radionuclide ILCRs were developed for surface and shallow subsurface soils. However, the risks for the individual media were not combined. These cumulative ILCRs included all media and pathways that were appropriate to combine. Combined pathways occur when there is potential for an individual to be exposed to multiple pathways at the same given instant in time. Where the cumulative ILCR site risk to an individual based on the RME for both current and future land use is less than $10^{-4}$, action generally is not warranted unless there are adverse environmental impacts (EPA, 1991b).

\section{D.3.2.3 Results of the Human Health Dose/Risk Characterization}

The results for each potential receptor are as follows:

- Recreational User in Contact with Soil - the maximum dose was 7.7 x $10^{-4} \mathrm{mrem} / \mathrm{yr}$ at 23 years (i.e., 2023) and the cumulative ILCR was $1.4 \times 10^{-8}$

- Rancher User in Contact with Soil - the maximum dose was 1.7 x $10^{-3} \mathrm{mrem} / \mathrm{yr}$ at 23 years (i.e., 2023) and the cumulative ILCR was $2.8 \times 10^{-8}$

- Native American User in Contact with Soil - the maximum dose was $7.8 \times 10^{-4} \mathrm{mrem} / \mathrm{yr}$ at 23 years (i.e., 2023) and the cumulative ILCR was $1.4 \times 10^{-8}$

The difference in the dose numbers for the recreational user and Native American user scenarios, although the ILCR numbers are the same, is due to rounding. 
Based on the maximum detected tritium activity, all of the potential doses are significantly below the allowable dose of $25 \mathrm{mrem} / \mathrm{yr}$ and the potential risks were significantly below the lower bound ILCR of $1.0 \times 10^{-6}$. The site does not pose a potential risk to human health based on exposure to tritium in soil. Based on the significant number analytical samples (both historical and confirmatory) and the overall potential dose, no further soil sampling for tritium is necessary. 


\section{D.4.0 References}

ANL, see Argonne National Laboratory.

Anspaugh, L.R., J.H. Shinn, and D.W. Wilson. 1974. "Evaluation of the Resuspension Pathway Toward Protective Guidelines for Soil Contamination with Radioactivity." In Proceedings Seminar on Radiological Safety Evaluation of Population Doses and Application of Radiological Safety Standards to Man and Environment, Portaraz, Yugoslavia, 20-24 May, 1974; 513. Vienna Austria: International Atomic Energy Agency.

Argonne National Laboratory. 1993a. Data Collection Handbook to Support Modeling the Impacts of Radioactive Material in Soil, ANL/EAIS-8. Prepared by C. Yu, C. Loureiro, J.J. Cheng, L.G. Jones, Y.Y. Wang, Y.P. Chia, and E. Faillace. Argonne, IL.

Argonne National Laboratory. 1993b. Manual for Implementing Residual Radioactive Material Guidelines Using RESRAD, Version 5.0, ANL/EAD/LD-2. Prepared by C. Yu, A.J. Zielen, J.J. Cheng, Y.C. Yuan, L.G. Jones, D.J. LePoire, Y.Y. Wang, C.O. Loureiro, E. Gnanapragasam, E. Faillace, A. Wallo III, W.A. Williams, and H. Peterson. Argonne, IL.

Argonne National Laboratory. 1999. RESRAD for Windows, Version 5.95. Argonne, IL: Environmental Assessment Division.

CFR, see Code of Federal Regulations.

Code of Federal Regulations. 1999. Title 40, Part 300, "National Oil and Hazardous Substances Pollution Contingency Plan." Washington, DC: U.S. Government Printing Office.

Code of Federal Regulations. 2000. Title 10, Part 20, "Standards for Protection Against Radiation." Washington, DC: U.S. Government Printing Office.

DOE, see U.S. Department of Energy.

DOE/NV, see U.S. Department of Energy, Nevada Operations Office.

EPA, see U.S. Environmental Protection Agency.

U.S. Department of Energy. 1993. Radiation Protection of the Public and the Environment, Order 5400.5. Washington, D.C.

U.S. Department of Energy. 1997. Draft, Applying the ALARA Process for Radiations Protection of the Public and Environmental Compliance with 10 CFR Part 834 and DOE 5400.5 ALARA Program Requirements - Volumes I and II. Washington, DC. 
U.S. Environmental Protection Agency. 1989. "Risk Assessment Guidance for Superfund (RAGS), Vol. I, Human Health Evaluation Manual (Part A)," OSWER Directive 9285.7-01A. Washington, DC: Office of Emergency and Remedial Response.

U.S. Environmental Protection Agency. 1991a. "Risk Assessment Guidance for Superfund, Human Health Evaluation Manual, Supplemental Guidance: Standard Default Exposure Factors," OSWER Directive 9285.6-03, Vol. I. Washington, DC: Office of Solid Waste and Emergency Response.

U.S. Environmental Protection Agency. 1991b. Role of the Baseline Risk Assessment in Superfund Remedy Selection Decisions, OSWER Directive 9355.0-30. Washington, DC: Office of Solid Waste and Emergency Response.

U.S. Environmental Protection Agency. 1995. Health Effect Assessment Summary Tables (HEAST), Annual FY 1993, OERR 9200.6-303 (92-1). Washington, DC: Office of Emergency and Remedial Response.

U.S. Environmental Protection Agency. 1999. "Current Drinking Water Standards: National Primary and Secondary Drinking Water Standards," on-line database. Revised December, 1999. Washington, DC.

WRCC, see Western Regional Climate Center.

Western Regional Climate Center. 2000. Monthly Climate Summary for Gavilan, NM. Period of Record 10/1/1929 to 1/31/1970. As accessed on wrcc@ dri.edu on 3 November 2000. 


\section{Distribution}

\section{Copies}

Monica Sanchez

Environmental Restoration Division

DOE/Nevada Operations Office

P.O. Box 98518, M/S 505

Las Vegas, NV 89193-8518

Bill Wilborn

Environmental Restoration Division

DOE/Nevada Operations Office

P.O. Box 98518, M/S 505

Las Vegas, NV 89193-8518

Sabrina Lawrence

Environmental Restoration Division

DOE/Nevada Operations Office

P.O. Box 98518, M/S 505

Las Vegas, NV 89193-8518

Jenny Chapman

Desert Research Institute

P.O. Box 19040, M/S 433

Las Vegas, NV 89132-0040

Dave Stahl

IT Corporation

P.O. Box 93838, M/S 439

Las Vegas, NV 89193

Robert Boehlecke

SAIC

P.O. Box 93838, M/S 439

Las Vegas, NV 89193

Denny G. Foust
1 (Controlled)

1 (Controlled)

1 (Controlled)

3 (Uncontrolled)

1 (Controlled)

2 (Uncontrolled)

1 (Controlled)

2 (Controlled)

4 (Uncontrolled)
Oil Conservation Division

State of New Mexico Energy Minerals, and Natural Resources Department 1000 Rio Brazos Road Aztec, NM 87410 
James Bearzi

New Mexico Environment Department

Hazardous and Radioactive Materials Bureau

2044-A Galisteo

P.O. Box 26110

Santa Fe, NM 87502

U.S. Department of Energy

Nevada Operations Office

Technical Information Resource Center

P.O. Box 98518, M/S 505

Las Vegas, NV 89193-8518

U.S. Department of Energy

Nevada Operations Office

Public Reading Room

P.O. Box 98521

Las Vegas, NV 89193-8521

U.S. Department of Energy

Office of Scientific and Technical Information

P.O. Box 62

Oak Ridge, TN 37831-0062

IT Corporation

Central Files

P.O. Box 93838, M/S 439

Las Vegas, NV 89193
2 (Controlled)

1 (Uncontrolled)

1 (Controlled)

1 (Uncontrolled)

1 (Electronic Copy)

1 (Uncontrolled) 